
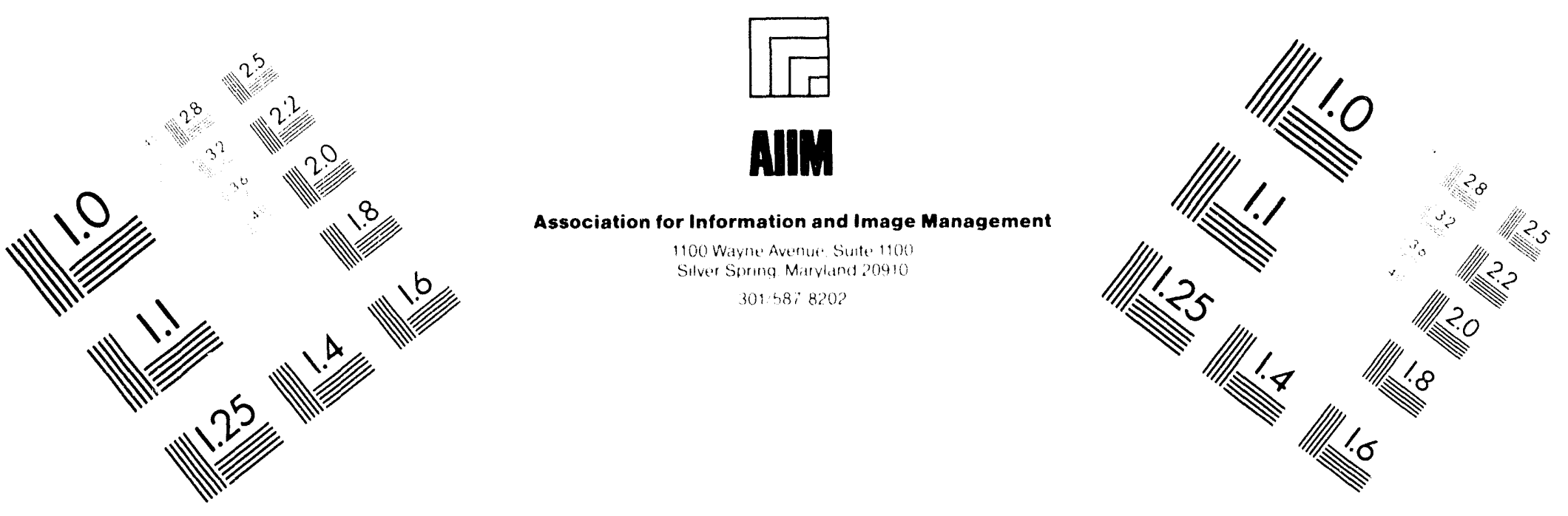

Centimeter

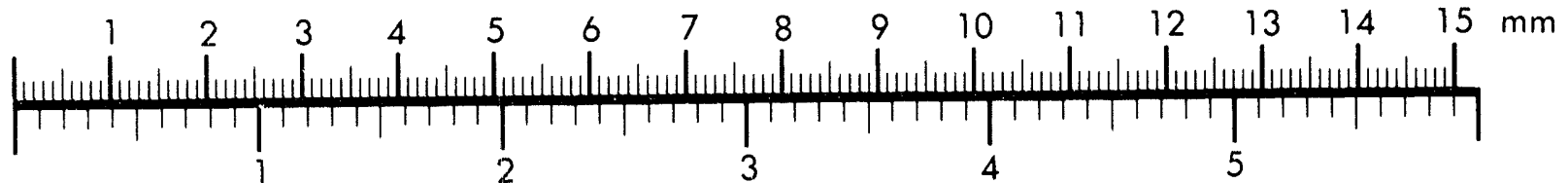
Inches
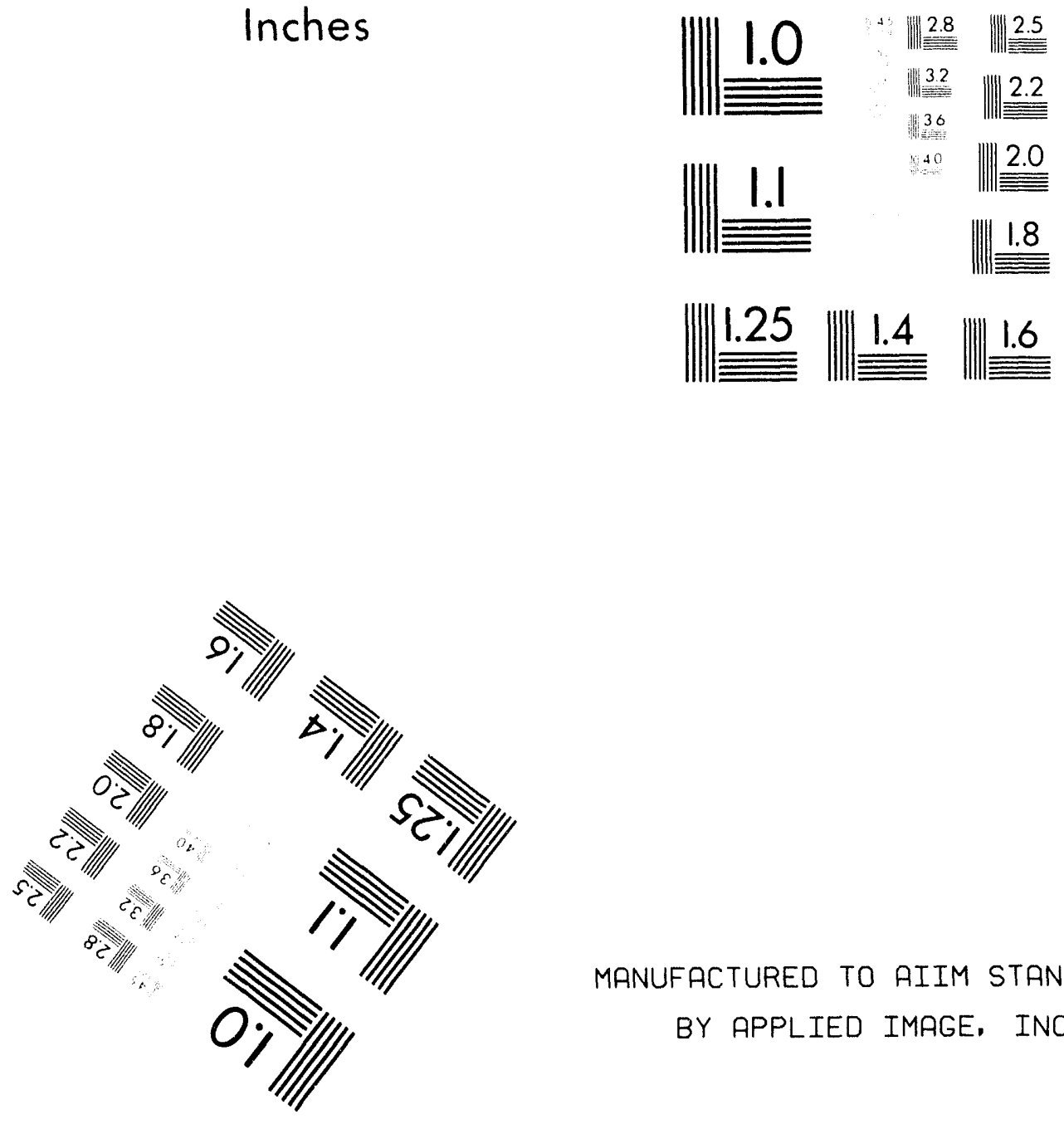

MANUFACTURED TO AIIM STANDARDS BY APPLIED IMAGE, INC.

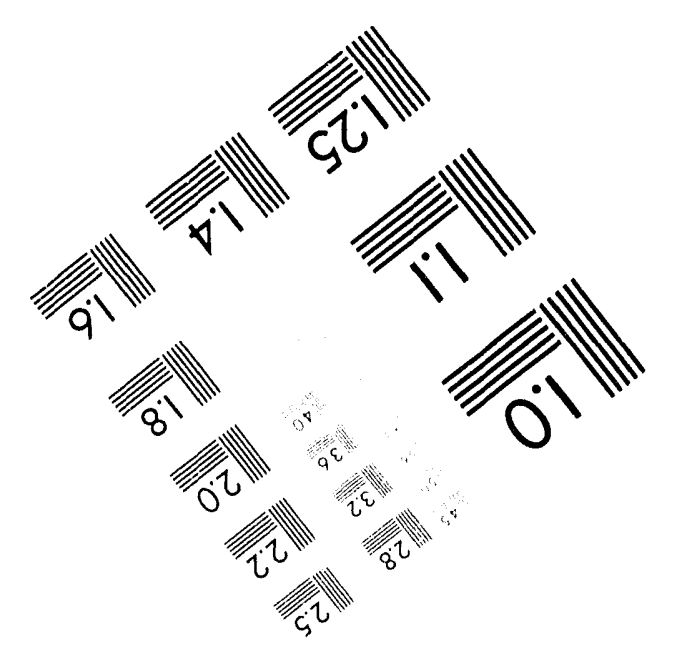



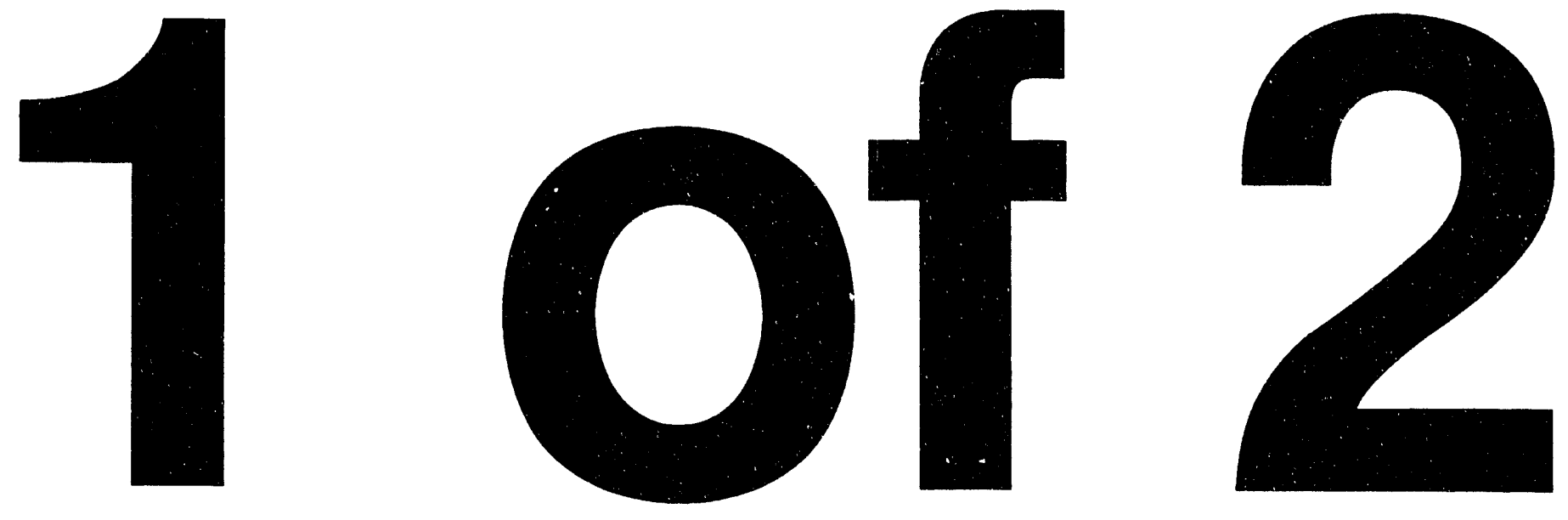
DOE/EIA-0580

Distribution Caregory UC-950

\section{Financial Impacts of Nonutility Power Purchases on Investor-Owned Electric Utilities}

June 1994

Energy Information Administration

Office of Coal, Nuclear, Electric and Alternate Fuels

U.S. Department of Energy

Washington, DC 20585

OCOMnBUTION OF THIS DOCUMENT IS UNLIMITEO

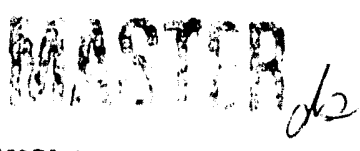

This report was prepared by the Energy Information Administration, the independent statistical and analytical agency within the Department of Energy. The information contained herein should not be construed as advocating or reflecting any policy position of the Department of Energy or of any other organization. 


\section{Preface}

Section 205(a)(2) of the Department of Energy Organization Act of 1977 (Public Law 95-91) requires the Administrator of the Energy Information Administration (EIA) to carry out a central, comprehensive, and unified energy data and information program that will collect, evaluate, assemble, analyze, and disseminate data and information relevant to energy resources, reserves, production, demand technology, and related economic and statistical information. To assist in meeting these responsibilities in the area of electric power, EIA has prepared this report, Financial Impacts of Nonutility Power Purchases on Investor-Owned Electric Utilities.

The primary purpose of this report is to provide an overview of the issues surrounding the financial impacts of nonutility generation contracts (since the passage of the Public Utility Regulatory Policies Act of 1978) on investor-owned utilities. The existing concern in this area is manifest in the provisions of Section 712 of the Energy Policy Act of 1992, which required State regulatory commissions to evaluate various aspects of long-term power purchase contracts, including their impact on investor-owned utilities' cost of capital and rates charged to customers.
The legislation that created the EIA vested the organization with an element of statutory independence. The EIA does not take positions on policy questions. The EIA's responsibility is to provide timely, high quality information and to perform objective, credible analyses in support of the deliberations by both public and private decision-makers. Accordingly, this report does not purport to represent the policy positions of the U.S. Department of Energy or the Administration.

This report was prepared by the staff of the Supply Analysis Branch, Analysis and Systems Division, Office of Coal, Nuclear, Electric and Alternate Fuels. General information regarding this publication may be obtained from Robert M. Schnapp, Director, Analysis and Systems Division (202-254-5392); Betsy O'Brien, Chief, Supply Analysis Branch (202-254-5490); or Art Fuldner, Team Leader (202-254-5321). Specific questions regarding the content of this report should be addressed to Dr. Suraj P. Kanhouwa (202-254-5779), Project Manager and principal author. Robert Mumper (202-254-5628) and Ronald Hankey (202-254-5333) provided technical support and assistance. 


\section{Contents}

Executive Summary $\ldots \ldots \ldots \ldots \ldots \ldots \ldots \ldots \ldots \ldots \ldots \ldots \ldots \ldots \ldots \ldots \ldots \ldots \ldots \ldots \ldots \ldots \ldots$

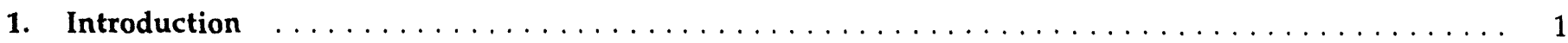

2. Financial Status of the Electric Utility Industry, $1981-1992 \ldots \ldots \ldots \ldots \ldots \ldots \ldots \ldots \ldots \ldots \ldots$

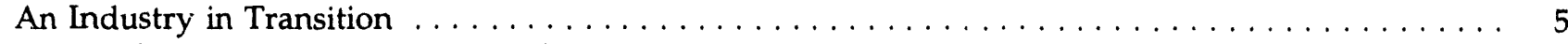

Financial Review of Investor-Owned Utilities $\ldots \ldots \ldots \ldots \ldots \ldots \ldots \ldots \ldots \ldots \ldots \ldots \ldots \ldots$

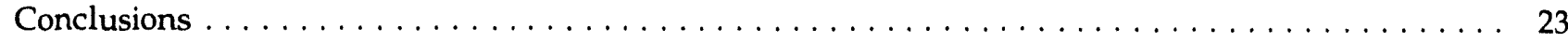

3. Financial Impacts of Nonutility Power Purchases on Utility Cost of Capital $\ldots \ldots \ldots \ldots \ldots \ldots$

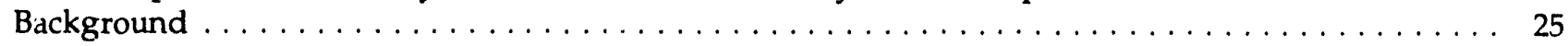

Comparative Financial Assessment of Two Investor-Owned Utility Groups with and without

Nonutility Power Purchase Contracts $\ldots \ldots \ldots \ldots \ldots \ldots \ldots \ldots \ldots \ldots \ldots \ldots \ldots \ldots$

Impact of Power Purchases from Nonutilities on the Utility Cost of Capital:

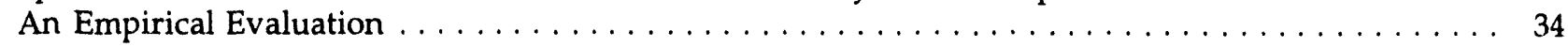

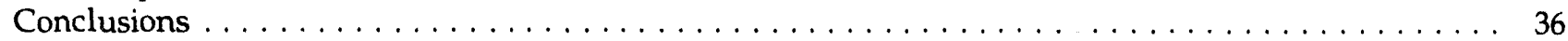

4. Purchased Power Debate and The Energy Policy Act of $1992 \ldots \ldots \ldots \ldots \ldots \ldots \ldots \ldots \ldots \ldots \ldots$

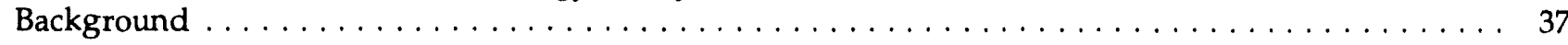

Section 712 of the Energy Policy Act of $1992 \ldots \ldots \ldots \ldots \ldots \ldots \ldots \ldots \ldots \ldots \ldots \ldots \ldots \ldots \ldots$

Summary of Regulatory Response to Section 712 Standards $\ldots \ldots \ldots \ldots \ldots \ldots \ldots \ldots \ldots \ldots \ldots$

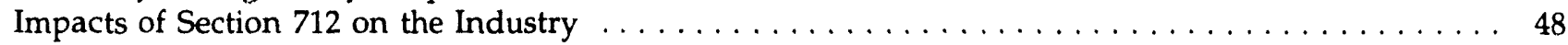

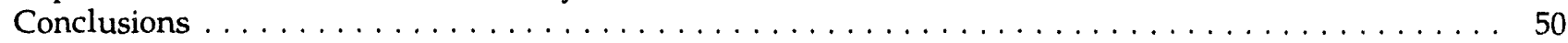

\section{Appendices}

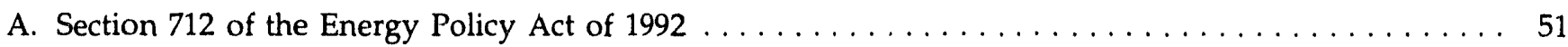

B. Listing of Two Groups of Investor-Owned Utilities with and without Significant Power Purchases

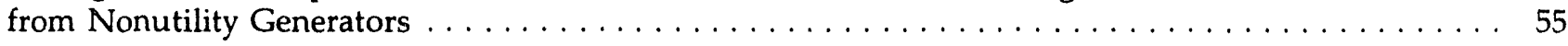

C. Cost of Equity Capital Estimation: Methodology, Measurement Issues, Data, and Regression Results . 59

D. Selected Provisions of the Public Utility Regulatory Policies Act of 1978 as Amended . . . . . . . . . 87

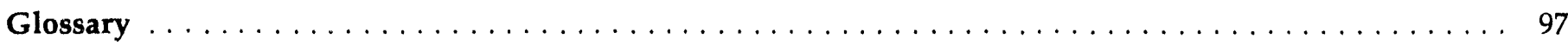


1. Selected Economic Parameters of the U.S. Economy, $1970-1992 \ldots \ldots \ldots \ldots \ldots \ldots \ldots \ldots \ldots \ldots$

2. Aggregate End-Use Electricity Sales and Total Installed Capacity of the Electric Utility Industry, 1970-1992

3. Selected Electric Utility Data by Ownership, as of December 31, $1992 \ldots \ldots$

4. Capacity and Generation Statistics for the Nonutility Generating Sector, $1992 \ldots \ldots \ldots \ldots \ldots \ldots$

5. Composite Financial Statistics for Investor-Owned Electric Utilities, $1981-1992 \ldots \ldots \ldots \ldots \ldots \ldots \ldots$

6. Outstanding Electric Construction Work in Progress as a Share of Total or Net Electric Utility Plant for

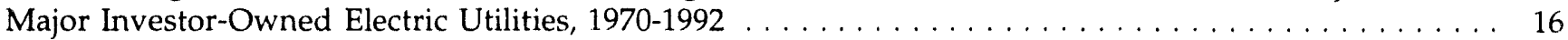

7. Total Debt of Major Investor-Owned Utilities and Interest Coverage Ratios, Selected Years, 1970-1992 . 18

8. Capital Structure of U.S. Investor-Owned Utilities, $1970-1992 \ldots \ldots \ldots \ldots \ldots \ldots \ldots \ldots \ldots$

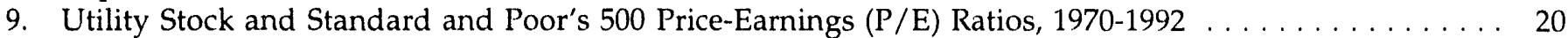

10. Market Price and Book Value of Utility Common Stocks, $1970-1992 \ldots \ldots \ldots \ldots \ldots \ldots \ldots \ldots \ldots$

11. Disposition of Net Income per Share, $1970-1992 \ldots \ldots \ldots \ldots \ldots \ldots \ldots \ldots \ldots \ldots \ldots \ldots \ldots \ldots \ldots . \ldots 22$

12. Financial and Other Statistics of a Selected Group of Investor-Owned Utilities with Significant Power Purchases from Nonutility Generators, $1986-1992 \ldots \ldots \ldots \ldots \ldots \ldots \ldots \ldots \ldots$. . . . 27

13. Financial and Other Statistics of a Selected Group of Investor-Owned Utilities without Significant Power Purchases from Nonutility Generators, $1986-1992 \ldots \ldots \ldots \ldots \ldots \ldots \ldots \ldots$

14. Comparative Ratios and Indicators for SIGNUGs and NONUGs, $1986-1992 \ldots \ldots \ldots \ldots \ldots \ldots$

15. A Simplified Example of Differences in Capital Costs . . . . . . . . . . . . . . . . . . . . . . . . 44

16. Summary of State Commission Determinations Regarding Section 712 Standards of the Energy Policy Act 0

B1. List of Investor-Owned Utilities with Significant Power Purchases from Nonutility Generators . . . . . 57

B2. List of Investor-Owned Utilities without Significant Power Purchases from Nonutility Generators . . . 58

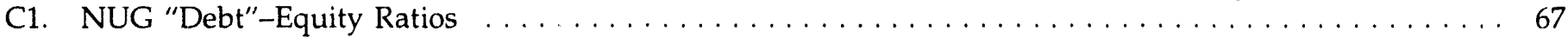

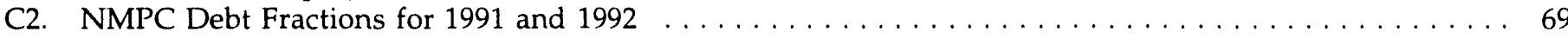

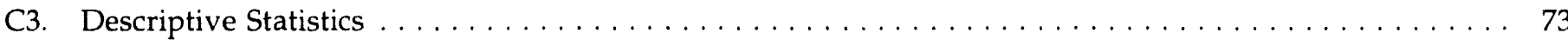

C4. Correlations Among Cost-of-Capital Variables $\ldots \ldots \ldots \ldots \ldots \ldots \ldots \ldots \ldots \ldots \ldots \ldots \ldots \ldots \ldots \ldots$

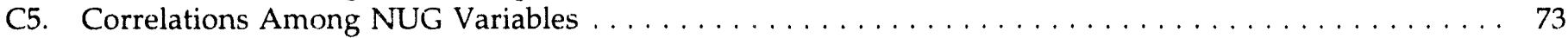

C6. Capital Asset Pricing Model Regression Results $\ldots \ldots \ldots \ldots \ldots \ldots \ldots \ldots \ldots \ldots \ldots \ldots \ldots \ldots$

C7. Tesi for Equality of the NUG and C Coefficients $\ldots \ldots \ldots \ldots \ldots \ldots \ldots \ldots \ldots \ldots \ldots \ldots \ldots$

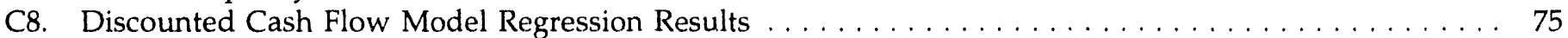

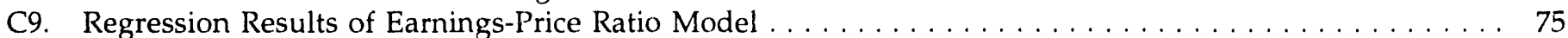

C10. Earnings-Price Ratio without Proxy Cost Firms $\ldots \ldots \ldots \ldots \ldots \ldots \ldots \ldots \ldots \ldots \ldots \ldots \ldots$

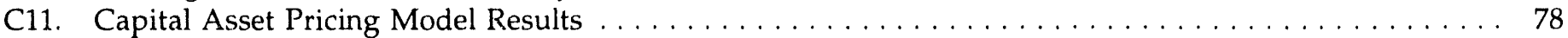

C12. Discounted Cash Flow Results $\ldots \ldots \ldots \ldots \ldots \ldots \ldots \ldots \ldots \ldots \ldots \ldots \ldots \ldots \ldots \ldots \ldots \ldots \ldots \ldots \ldots$

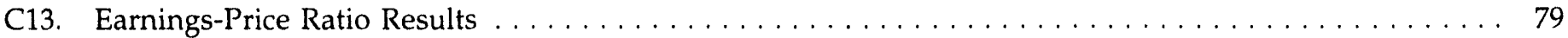

C14. Adjusted $R^{2}$ for 3 and 5 Variable Specifications $\ldots \ldots \ldots \ldots \ldots \ldots \ldots \ldots \ldots \ldots \ldots \ldots$

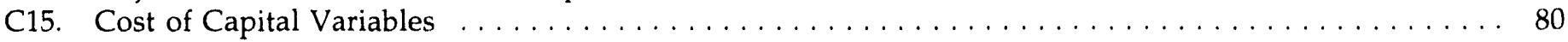

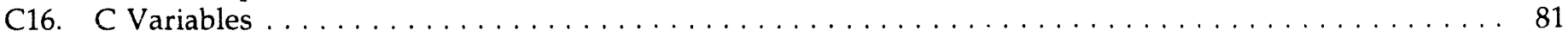

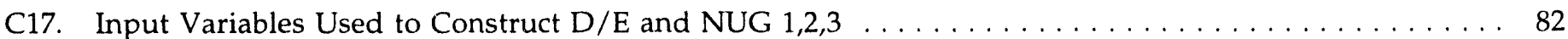

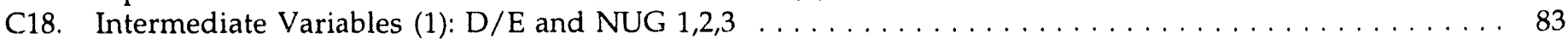

C19. Intermediate Variables (2): $\mathrm{D} / \mathrm{E}$ and NUG $1,2,3 \ldots \ldots \ldots \ldots \ldots \ldots \ldots \ldots \ldots \ldots$

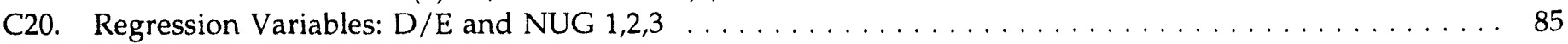


1. Electric Operating Revenues, $1981-1992 \ldots \ldots \ldots \ldots \ldots \ldots \ldots \ldots \ldots \ldots \ldots \ldots \ldots \ldots \ldots \ldots$

2. Annual Percentage Changes in Electric Operating Revenues from Previous Year, 1981-1992 _ . . . . . . 14

3. Real and Nominal Retail Prices of Electricity Sold by Electric Utilities, 1981-1992 . . . . . . . . . . . . 14

4. Net Electric Operating Income as a Share of Electric Operating Revenues, 1981-1992 _ . . . . . . . . 15

5. Allowances for Funds Used During Construction as a Component of Net Income of Major

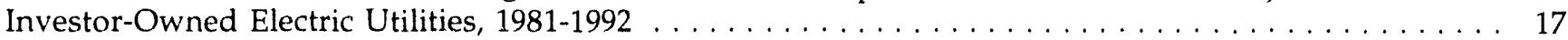

6. Comparative Components of Capitalization Between SIGNUGs and NONUGs, $1986-1992 \ldots \ldots \ldots$. . . 31

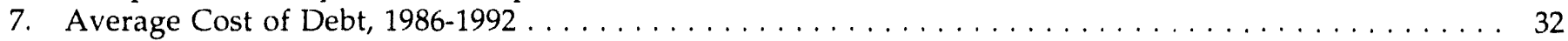

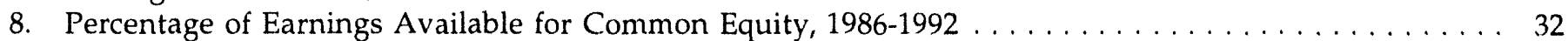

9. Interest Expenses as a Percentage of Earnings, $1986-1992 \ldots \ldots \ldots \ldots \ldots \ldots \ldots \ldots \ldots \ldots \ldots$

10. Capital Expenditures is a Percentage of Net Utility Plant, $1986-1992 \ldots \ldots \ldots \ldots \ldots \ldots \ldots \ldots \ldots$

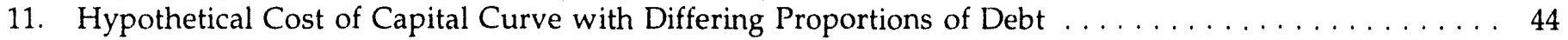




\section{Executive Summary}

The Public Utility Regulatory Policies Act of 1978 (PURPA) spurred the sale of nonutility power to the U.S. electric utilities. PURPA required the electric utilities to interconnect with and purchase power from any qualifying facility. ${ }^{1}$ As a result, nonutility generation increased at an average annual rate of about 17 percent between 1985 and 1992, to 296.0 billion kilowatthours. The investor-owned utilities purchased 164.2 billion kilowatthours of the total nonutility generation in 1992, representing almost 6 percent of total domestic end-use electricity sales.

By purchasing power, the investor-owned utilities substitute for or postpone the requirement to build capacity. ${ }^{2}$ Nonutility owners contend that this option to "buy" power enables the utilities to retain financial flexibility. Bond-rating agencies, however, treat fixed payments associated with power purchase contracts analogously with a utility's long-term debt. When power purchases by a utility become significant, i.e., greater than 10 percent of their capacity or total sales, bond-rating agencies add some portion of the fixed payment obligations to the utility's existing debt to compute its total long-term debt liability. This process has the potential of adversely affecting a utility's capitalization structure and also its interest coverage ratios. These adjustments may cause its bond-ratings to be downgraded leading to an increase in its cost of capital.

Section 712 of the Energy Policy Act of 1992 (EPACT) required State regulatory authorities to consider the need to adopt four new rulemaking standards regarding the purchase of wholesale power by amending Section 111 of the PURPA regulations. The new standards include an evaluation of: (1) the effects of longterm wholesale power purchases on utility cost of capital and on retail rates, (2) the effects of leveraged capital structures on the reliability of the wholesale power sellers, (3) whether to implement procedures for the advance approval or disapproval of long-term power purchase contracts, and (4) whether to require the assurance of adequate fuel supplies before approval of power purchase contracts. EPACT further stipulated that consideration of these issues be completed by October 23, 1993.

Most State regulatory authorities have completed the required evaluations. Of the States that have completed the evaluation process, with one exception, all rejected adopting the Section 712 standards on the ground that adopting standards that would hold good for all future contingencies would be difficult to attain. The States believe that they have adequate authority under the existing legislation to look into areas of concern within the framework of either integrated resource, least-cost planning procedures, or ratemaking hearings. None of the States minimized the relevance of the issues raised but they conceded that it would be more appropriate for them to retain the flexibility to examine issues on a case-by-case basis rather than adopt ad hoc standards.

The relevance of Section 712 requirements lies in drawing attention to various issues that follow from power purchase contracts. This analysis report examines and evaluates the financial impacts of long-term power purchases by investor-owned utilities from nonutility generators. The starting point of this analysis is an overview of the financial developments affecting the investor-owned utilities during the 1980s. The analysis shows that the 1980s generally ushered in a period of financial recovery, rehabilitation, and growth for the investor-owned utilities.

Two different approaches are used to evaluate the financial issues associated with power purchases. First, two composite and comparable data sets-one

\footnotetext{
'Qualifying facilities are nonutilities that meet the requirements specified by Public Utility Regulatory Policies Act of 1978 (Public Law 95-167). The requirements include that the facility generate electricity using a technology which either sequentially produces electric energy and another form of useful energy (such as heat or steam) using the same fuel source (cogeneration) or uses renewable energy as a fuel source. In addition, qualifying facilities must meet certain ownership, operating, and efficiency criteria established by the Federal Energy Regulatory Commission. Nonqualifying facilities are nonutilities that do not meet these requirements. This analysis report treats nonutility generation as all electricity producers except utilities.

${ }^{2}$ This statement does not take into account instances where some investor-owned utilities had to buy power while facing existing surpluses in capacity.
} 
comprising investor-owned utilities with significant power purchases from nonutility generators and the other without such purchases, are created by abstracting data from FERC Form 1 for the 1986-1992 period. $^{3}$ Various financial ratios, derived by using composite financial data for the two groups, are compared to determine if there are performance differences between them. The intent is to assess whether there is an emerging trend in key financial and performance ratios that show differences between the two groups that can be attributed, in part, to purchased power contracts and in particular to nonutility generators.

The second approach analyzes the same problem from the perspective of equity markets. The underlying assumption is that if power purchases from nonutility generators in fact add to the riskiness of a utility and raise its cost of capital, then this phenomenon should be observable in the equity market as well. A general econometric framework in which to examine relevant determinants of the utility cost of capital is defined to perform the analysis.

The first analysis, i.e., a comparative financial analysis of two investor-owned groups with and without power purchase contracts for the period from 1986 through 1992 shows that:

- Capitalization ratios ${ }^{4}$ for the two groups did not materially differ.

- The data did not support the hypothesis that utilities with significant power purchases incurred a higher cost of capital than did the utilities without such a commitment. In fact, the evidence shows that utilities with little or no power purchase commitments had to bear a slightly higher cost of capital in comparison with the cost borne by the other group.

- In the area of allocation of earnings between debt and equity, utilities with significant power purchases paid slightly more for interest expenses than those without such purchases. However, it could not be determined whether the observed minor disparity resulted from power purchases.

- Utilities without power purchases had a higher share of operating income as a percentage of operating revenues than the utilities with power purchases. Although utilities do not earn a return on power purchase expenses, difficulties exist in attributing the difference in operating income exclusively to power purchases

- Utilities with significant power purchases charged a higher rate per kilowatthour of power sold. This disparity may be attributed to their location in high-cost generation areas (i.e., New York and California).

- Utilities with significant power purchases were found to also have more capital investments than the other group.

The second analytical approach is based on the premise that debt and equity markets are linked. It is argued that if there is an increase in the imputed debt of utilities as a result of power purchases from nonutility generators, then this results in an overall increase in the riskiness of the firm. An increase in the cost of borrowing should also be reflected by an increase in the cost of raising equity.

The results indicate that nonutility power purchases did not raise a utility's cost of equity capital. In fact, there was more evidence to support the notion that utility construction raises the cost of capital more than nonutility power purchases do. If these results are correct, then the debate about the debt equivalence of fixed payments for power purchases reflects more on the distribution of income between debt and equity owners, rather than on the cost of capital.

Overall, based on the available financial data using two different approaches, there is no conclusive evidence that power purchases from nonutility generators raised the cost of capital to the utilities which purchase the electricity.

\footnotetext{
${ }^{3}$ Investor-owned utilities purchasing approximately 9.0 percent or more of power or capacity from nonutility generators were deemed to be "significant" buyers.

"The percentage of debt, or preferred stock, or common stock, or other equity to the total capital structure of an entity.
} 


\section{Introduction}

From 1985 through 1992, nonutility generation increased at an average annual growth rate of 17 percent, to 296.0 billion kilowathours. ${ }^{1}$ Of this amount, the investor-owned utilities purchased 164.2 billion kilowatthours or almost 6 percent of the electricity generated for sale to the ultimate end-use consumers. The remainder of the power produced by nonutilities was used by them internally. Their sales to investorowned utilities increased from 28.3 billion kilowatthours in 1985 reflecting an average annual growth rate of 29 percent.

Some of the above power purchases were mandatory due to the regulations established by the Federal Energy Regulatory Commission implementing the Public Utility Regulatory Policies Act of 1978 (Public Law 95-167). That legislation created a new class of electric power generators called "qualifying facilities" and guaranteed a market for the el stricity they produce at the "avoided cost" of the electric utility purchasing the power. ${ }^{2,3}$ Other power purchase contracts, with nonutilities that are not qualifying facilities, originated in response tc voluntary requests for bids from the investor-owned electric utilities.

A substantial debate has emerged over the financial impacts of power purchases from nonutilities on investor-owned utilities, shareholders of the utilities, and the customers or ratepayers. For example, the decision to buy power or build capacity may have different financial implications on the credit rating of an investor-owned utility. The outcome of this debate could lead to changes in the organization, structure, and market behavior of the electric power industry. The seriousness of the debate is reflected in the provisions of Section 712 of the Energy Policy Act of 1992 (EPACT), Public Law 102-486, which requires State regulatory authorities to consider (among other related issues) whether the long-term power purchase agreements by the investor-owned utilities (from nonutility generators) would increase or decrease the utilities' cost of capital. ${ }^{4}$

The basis for concern is the manner in which the nonutility power projects are financed. The vast majority of these facilities use project financing, which relies on long-term purchase contracts with utilities to provide an assured market and price for the electricity, subject to performance requirements. Some financial analysts maintain that when utilities enter into long-term power purchase agreements, they assume financial risks. The payment agreements (in particular the capacity payments) are viewed as being analogous to off-balancesheet debt equivalents and are taken into account by the bond-rating agencies in the financial markets.

\footnotetext{
'Energy Information Administration, Financial Statistics of Major U.S. Investor-Owned Electric Utilities 1992, DOE/EIA-(0437(92)/1 (Washington, DC, December 1993), p. 49; The Changing Structure of the Electric Power Industry 1970-1991, DOE/EIA-0562 (Washington, DC, March 1993), p. 87; and Electric Power Annual 1992, DOE/EIA-0348(92) (Washington, DC, January 1994), p. 119.

${ }^{2}$ Qualifying facilities are nonutilities that meet the requirements specified by Public Utility Regulatory Policies Act of 1978 (Public Law 95-167). The requirements include that the facility generate electricity using a technology which either sequentially produces electric energy and another form of useful energy (such as heat or steam) using the same fuel source (cogeneration) or uses renewable energy as a fuel source. In addition, qualifying facilities must meet certain ownership, operating, and efficiency criteria established by the Federal Energy Regulatory Commission. Nonqualifying facilities are nonutilities that do not meet these requirements.

"Avoided cost" is generally assumed to be the cost that a utility avoided by not producing the electricity received/purchased from a qualifying facility. Because the demand and supply balance for electricity was not considered in avoided cost, its interpretation forced utilities to pay for QF capacity that was not needed. Since the mid-1980s, many States addressed this problem by introducing competitive bidding to establish avoided costs as opposed to setting them administratively. See Energy Information Administration, Changing Structure of the Electric Power Industry 1970-1991, DOE/EIA-0562 (Washington, DC, March 1993), p. 24.

${ }^{4} E P A C T$ represents comprehensive energy legislation that will impact on the operations of electric utilities in a significant way. Critical among its major provisions are the amendments to the Public Utility Holding Company Act of 1935 (PUHCA), the Federal Power Act (FPA), and Public Utility Regulatory Policies Act of 1978 (PURPA). Some provisions bolster competition, while others may imply added government intervention. The purpose of this study is to focus primarily on the provisions of Section 712 that affect the electric utilities.
} 
As a result, in cases where an investor-owned utility enters into long-term power purchase contracts that represent a significant part of its supply, such purchases increase the utility's indebtedness. ${ }^{5}$ This may diminish the credit strength of the investor-owned utility and lead to an eventual decline in its credit rating. ${ }^{6}$ The utility may, therefore, have to pay a higher rate of return to its equity holders to attract fresh capital. A similar argument holds where bonds need to be sold to finance the construction of new capacity.

This analysis report is designed to examine the issues stemming from the consequences of long-term power purchases from nonutility generators. To meet this analytical agenda, the report evaluates the consequences of purchased power contracts on the investor-owned utilities in ways that are both traditional and nontraditional. The traditional analysis evaluates the financial statements of two groups of investor-owned utilities: the first group with significant power purchases from nonutility generators and the other group without such purchases. The emphasis is to closely evaluate the quality of earnings of these two groups to discern whether there are any major performance differences between them. The nontraditional approach relies on the concept of efficient capital markets and empirically tests the impact of significant power purchase agreements (by an investor-owned utility) on the utilities' cost of equity capital.

The starting point for this report is an overview of the financial developments during the 1980s that affected the investor-owned utilities. The 1980s turned out to be a decade of transition for the electric power industry. It was a period of consolidation and recovery as many major construction projects were completed, the economy recovered, wholesale power transfers increased, and nonutility generators that sold power to the electricity grid emerged. The industry also experienced many regulatory changes that were evolutionary: ratebase phasein, cost disallowances, performance-based pricing, modified treatment of investments embedded in the construction work in progress, and definitions of avoided cost. All these factors affected the financial status of the investor-owned utilities.
Chapter 2 provides a historical background of the electric utility industry since the early 1980s and evaluates the changes in electric utility operating revenues, incomes, prices, earnings, and capital structures in general. Within this framework, the perceptions of the financial community in dealing with investor-owned utilities that purchase a significant share of power will be introduced. In particular, bond-rating agencies' evaluations of the financial strength of such investorowned utilities will be discussed.

Chapter 3 applies standard financial analysis techniques to two groups of investor-owned utilities-those with significant power purchases from nonutility generators and those without significant power purchases. ${ }^{7}$ The analysis focuses on the most recent years, 1986-1992, i.e., the period during which the impact of power purchase agreements has become increasingly recognizable. Financial data from the Federal Energy Regulatory Commission (FERC) Form 1 are used for selected variables, and standard financial ratios are presented. The results of the group with significant power purchases are compared with those of the other set of investor-owned utilities that normally generate their own power, and do not rely on nonutility power generation to meet their load on a permanent basis.

In addition, the same problem is analyzed from the perspective of equity markets on the assumption that the debt and equity markets are inseparably linked. If power purchase agreements (and the associated capacity payments) are analogous to debt, then the conclusion that the operations of the firm become more risky should be observable in the equity markets as well. Accordingly, this chapter evaluates the "debtequivalence" debate empirically. It establishes a general framework in which to examine those determinants of the utility cost of equity capital which are relevant to this debate. For this purpose, a basic form of an equation is tested empirically and an analysis of the results presented.

Chapter 4 deals with the issues raised by the recently enacted Energy Policy Act of 1992 as stipulated in Section 712. These issues are:

\footnotetext{
${ }^{5}$ Power purchases from nonutility generators in excess of 10 percent of total sales or capacity are considere i significant by bond-rating agencies.

${ }^{6}$ Note, however, that bond-rating agencies take various other factors into account in assigning rating to a utility's bonds. As such, a utility may confront the possibility of having its bonds downgraded even when its power purchase contracts are less than the 10 percent "significant" level.

'Data as available with the Energy Information Administration on Form ElA-861, "Annual Electric Utility Report," Form EIA-867, "Annual Nonutility Power Producer Report," Form EIA 767, "Steam-Electric Plant Operation and Design Report," and Federal Energy Regulatory Commission FERC Form 1, "Annual Report of Major Electric Utilities, Licensees, and Others," were used to identify investorowned utilities purchasing power/capacity from nonutility generators (that include qualified facilities, independent power producers, small power producers or exempt wholesale generators) at levels close to or exceeding 9 percent.
} 
- Effects of power purchases on utility cost of capital and on retail rates paid by consumers

- Potential concerns regarding reliability attributable to highly leveraged capital structures of the exempt wholesale generators

- Consideration of implementing procedures for advance approval/disapproval of long-term wholesale power supply

- Assurances of adequate fuel supplies before approval of power purchase contracts.

A summary of the issues and views, as presented before the State regulatory authorities, is presented together with a summary of recommendations from the various commissions. The evidence, as available from the two preceding chapters, is then integrated into this discussion. Finally, conclusions of the study are presented.

The appendices provide background information. Appendix A contains Section 712 of the Energy Policy Act of 1992. Appendix B lists the two groups of investor-owned utilities with and without significant power purchases from nonutility generators. Appendix $C$ contains a detailed version of the empirical work done to assess the impact of nonutility power purchases on utilities' cost of equity capital. Appendix D lists selected provisions of the Public Utility Regulatory Policies Act of 1978. 


\section{Financial Status of the Electric Utility Industry, 1981-1992}

\section{An Industry in Transition}

\section{Background: The Seventies}

Major pressures on the financial health of the electric power industry emerged in the 1970s. These pressures came from different but related sources: the state of the economy, rising oil prices, reduced growth in demand for electricity, construction outlays, environmental regulations, and rising power plant costs. ${ }^{8}$

The state of the economy had a significant adverse impact on the electric power industry. The quadrupling of oil prices during the 1973-1974 Arab oil embargo pushed the economy into a recession. During 1974 and 1975, real output declined while inflation worsened significantly (Table 1). Even as the economy began to readjust structurally to increased energy prices during 1976 , the then prevailing high inflation and unemployment rates rendered the process difficult. A subsequent oil price shock in 1979 (in which oil prices doubled again) and its continuation in the following years set the stage for the most severe and prolonged recession of the post-war era. ${ }^{9}$

Accelerating inflation (leading to an increase in overall power plant construction costs and in operation and maintenance costs) and escalating fossil fuel prices (particularly oil and natural gas prices in the wake of the 1973-1974 Arab oil embargo) imposed cost pressures on the electric utility industry. The cumulative impact of these developments (in concert with the state of the economy) was an unanticipated deceleration in the overall grow th in demand for electricity. The average annual rate of growth in demand for electricity declined from 7.2 percent in 1970 through 1973 to 3.2 percent in 1973 through 1979 (Table 2). This development occurred while the industry was already in the midst of implementing an expansion program geared to meet historical growth rates exceeding 7.0 percent. As the expansion program was delayed, carrying charges (in the form of dividends on equity and interest on debt) for investments in the construction work in progress increased significantly due to increasing leadtimes necessary for project completion in an inflationary economic environment.

Slower growth in demand for power (with its impact on revenues) and rising utility expenditures squeezed industry profits and reduced the availability of funds from internal sources. To keep the level of construction activity (already in the pipeline) going, the industry had no other option but to increase its borrowings in the market. This activity raised the overall costs of producing power still higher.

As a result, the electric power industry confronted a period of unprecedented financial uncertainty. ${ }^{10}$ A matter of concern and debate in the late 1970s was whether the electric utility industry (particularly the investor-owned segment) would be able to successfully finance its future construction programs (to satisfy load

\footnotetext{
${ }^{8}$ Power plant costs escalated significantly during the late 1970 s and the early 1980 s.

${ }^{9}$ For additional details, refer to Energy Information Administration, Historical Financial Analysis of the Investor-Owned clectric Utility Industry, DOE/EIA-0443 (Washington, DC, February 1984), pp. 19-40.

${ }^{10}$ David L. Scott, Financing the Growth of Electric Utilities (New York, NY: Praeger Publishers, 1976), p. vi. An additional factor was the fuel choice legislation enacted during the 1970s which was designed to promote the greater use of coal in place of oil and natural gas. The Energy Supply and Environmental Coordination Act of 1974 (Public Law 93-319) directed the Federal Energy Administration to identify and prohibit plants from using oil/natural gas under certain conditions. The Powerplant and the Industrial Fuel Use Act of 1978 (Public Law 95-260) extended and intensified Federal involvement in utilities' future fuel choices by prohibiting the use of oil/natural gas in new power plant construction. This legislation also stipulated that the use of natural gas as primary boiler fuel would end on or before January 1, 1990.
} 
Table 1. Selected Economic Parameters of the U.S. Economy, 1970-1992

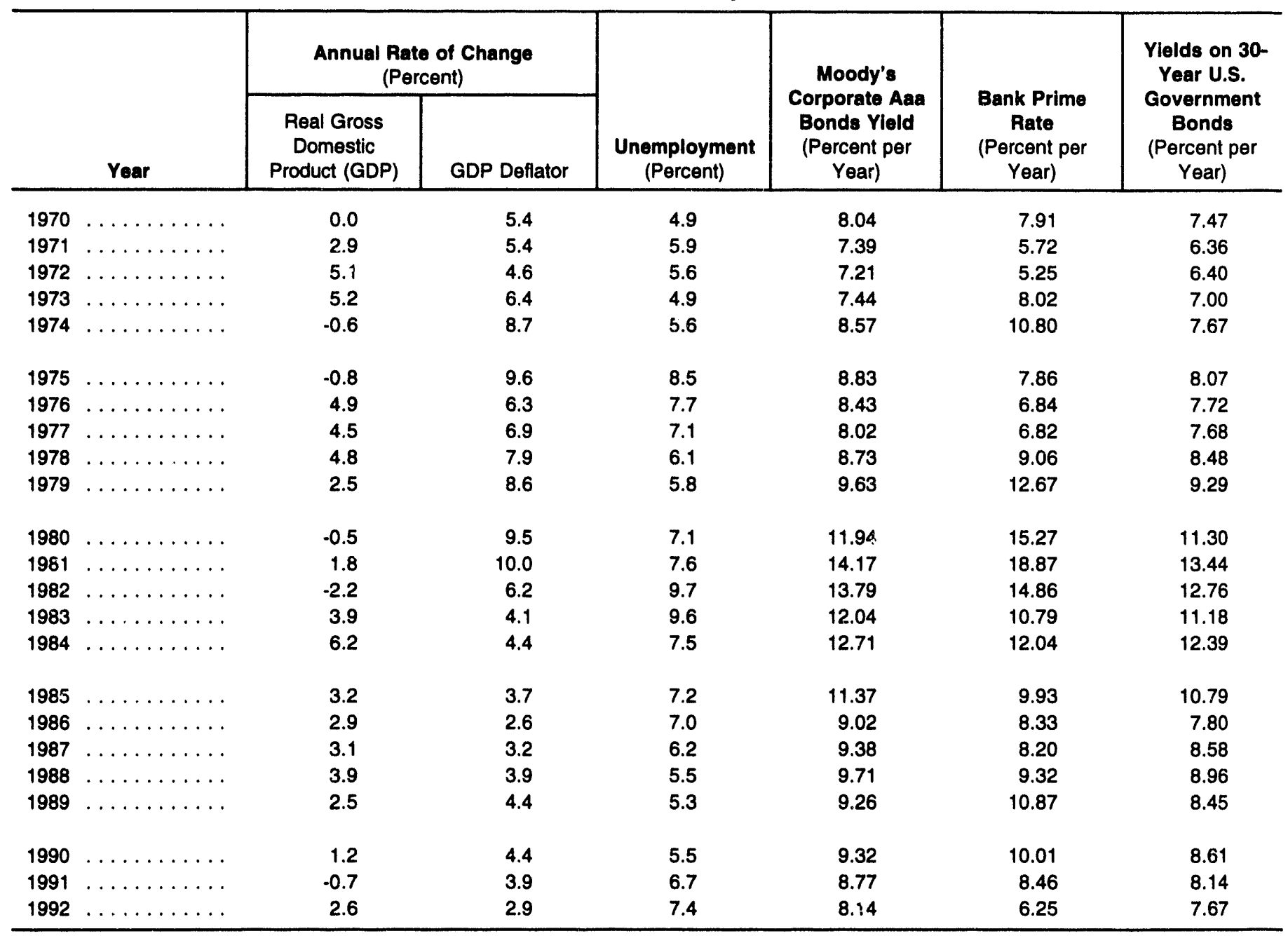

Sources: Real Gross Domestic Product (GDP) and GDP Deflator-Department of Commerce, Bureau of Economic Analysis, Survey of Current Business, Vol. 73, No. 9 (Washington, DC, September 1993), pp. 50, 53. Unemployment, Moody's Corporate Aaa Bonds Yleld-Council of Economic Advisors, Economic Report of the President (Washington, DC, January 1993), pp. 390, 428. Bank Prime Rate, Yields on 30-Year U.S. Government Bonds-The Wharton Econometrics Forecasting Associates (WEFA) Group, U.S. Long-Term Historical Data (Bala Cynwyd, PA, Fourth Quarter, 1993), p. 4.69, and predecessor publications.

requirements compatible with adequate reserve margin requirements) or face a credit crunch. ${ }^{11}$

Growing environmental concerns during the 1970s, however, led to the passage of the Clean Air Act Amendments of 1970 and 1977, which required utilities to reduce the level of sulfur dioxide emissions from new coal-fired power plants through the addition of flue gas desulfurization equipment or the use of low- sulfur coal. These new environmental standards raised the overall power production costs by adding to the operating and/or capital costs of coal-fired power plants.

Construction costs of power plants also escalated due to a variety of reasons. Critical among these were the state of the economy, continued inflation, rising interest rates, lengthening licensing and construction leadtimes,

\footnotetext{
"For factors leading the electric utility industry in to financial difficulties, see Energy Information Administration, The Feasibility of Financing Domestic Energy Development During 1978-1984, DOE/EIA-0184/2 (Washington, DC, May 1979), pp. 46-47. The seriousness of a potential credit crunch became apparent when legislation to establish an Energy Independence Authority to encourage and assure the flow of funds to those sectors of the economy critical to the development of energy sources was introduced in 1975. Among these, the electric utility industry was expected to receive a major share of the initial funding authority of $\$ 100$ billion. However, the legislation was not enacted.
} 
Table 2. Aggregate End-Use Electricity Sales and Total Installed Capacity of the Electric Utility Industry, 1970-1992

\begin{tabular}{|c|c|c|c|c|c|c|c|}
\hline \multirow{2}{*}{\multicolumn{2}{|c|}{ Year }} & \multicolumn{5}{|c|}{$\begin{array}{c}\text { Electricity Sales } \\
\text { (Billion Kilowatthours) }\end{array}$} & \multirow{2}{*}{$\begin{array}{c}\text { Installed } \\
\text { Nameplate } \\
\text { Generating } \\
\text { Capacity } \\
\text { (Gigawatts) }\end{array}$} \\
\hline & & Residential & Commercial & Industrial & Other & Total & \\
\hline 1970 & $\ldots \ldots \ldots \ldots \ldots$ & 466 & 307 & 571 & 48 & 1,392 & 341.6 \\
\hline 1971 & $\ldots \ldots \ldots \ldots \ldots$ & 500 & 329 & 589 & 51 & 1,470 & 368.9 \\
\hline 1972 & $\ldots \ldots \ldots \ldots \ldots$ & 539 & 359 & 641 & 56 & 1,595 & 398.6 \\
\hline 1973 & $\ldots \ldots \ldots \ldots \ldots \ldots$ & 579 & 388 & 686 & 59 & 1,713 & 442.4 \\
\hline 1974 & $\ldots \ldots \ldots \ldots \ldots \ldots$ & 578 & 385 & 685 & 58 & 1,706 & 477.6 \\
\hline 1975 & $\ldots \ldots \ldots \ldots \ldots$ & 588 & 403 & 688 & 68 & 1,747 & 508.3 \\
\hline 1976 & $\ldots \ldots \ldots \ldots \ldots$ & 606 & 425 & 754 & 70 & 1,855 & 531.0 \\
\hline 1977 & $\ldots \ldots \ldots \ldots \ldots$ & 645 & 447 & 786 & 71 & 1,948 & 560.2 \\
\hline 1978 & $\ldots \ldots \ldots \ldots \ldots$ & 674 & 461 & 809 & 73 & 2,018 & 579.2 \\
\hline 1979 & $\ldots \ldots \ldots \ldots \ldots$ & 683 & 473 & 842 & 73 & 2,071 & 598.3 \\
\hline 1980 & $\ldots \ldots \ldots \ldots \ldots$ & 717 & 488 & 815 & 74 & 2,094 & 613.5 \\
\hline 1981 & $\ldots \ldots \ldots \ldots \ldots$ & 722 & 514 & 826 & 85 & 2,147 & 634.8 \\
\hline 1982 & $\ldots \ldots \ldots \ldots \ldots$ & 730 & 526 & 745 & 86 & 2,086 & 650.1 \\
\hline 1983 & 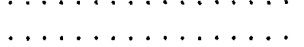 & 751 & 544 & 776 & 80 & 2,151 & 658.2 \\
\hline 1984 & $\ldots \ldots \ldots \ldots$ & 780 & 583 & 838 & 85 & 2,286 & 672.1 \\
\hline 1985 & $\ldots$ & 794 & 606 & 837 & 87 & $2,32: 4$ & 698.1 \\
\hline 1986 & $\ldots \ldots \ldots \ldots \ldots$ & 819 & 631 & 831 & 89 & 2,369 & 707.7 \\
\hline 1987 & $\ldots \ldots \ldots \ldots \ldots$ & 850 & 660 & 858 & 88 & 2,457 & 718.1 \\
\hline 1988 & $\ldots \ldots \ldots \ldots \ldots$ & 893 & 699 & 896 & 90 & 2,578 & 723.9 \\
\hline 1989 & $\ldots \ldots \ldots \ldots \ldots$ & 906 & 726 & 926 & 90 & 2,647 & 730.9 \\
\hline 1990 & & 924 & 751 & 946 & 92 & 2,713 & 735.1 \\
\hline 1991 & $\ldots \ldots \ldots \ldots$ & 955 & 766 & 947 & 94 & $2,76.2$ & 740.0 \\
\hline 1992 & $\ldots \ldots$ & 936 & 761 & 973 & 93 & 2,763 & 741.7 \\
\hline
\end{tabular}

Note: Sum of components may not equal total due to independent rounding.

Sources: Sales-Energy Information Administration, 1992 Annual Energy Review, DOE/EIA-0384(92) (Washington, DC, June 1993), p. 223 and Energy Information Administration, Electric Power Annual 1992, DOE/ElA-0348(92) (Washington, DC, January 1994), p. 52. Nameplate Capacity-1950-1982-Energy Information Administration, 1982 Annual Energy Review, DOE/EIA-0384(83) (Washington, DC, May 1983), p. 201. 1983-1992-Energy Information Administration, Form ElA-759, "Monthly Power Plant huport," and Energy Information Administration, Form ElA-767, "Steam-Electric Plant Operation and Design Report."

inclusion of pollution and environmental costs, and the inability to reap further economies of scale in building large base-load power plants. Nuclear power plant construction costs were additionally influenced by the accident at the Three Mile Island which brought about more stringent and added safety regulations requiring modifications to plants under construction and delays in obtaining an operating permit. ${ }^{12}$

Real electricity prices, which were relatively stable in 1970 through 1973, began to increase and continued increasing through $1982 .{ }^{13}$

\section{Financial Recovery and Structural Changes in the Eighties and Nineties}

The State regulatory authorities and the Federal Energy Regulatory Commission began responding to these financial pressures on the electric utility industry with evolutionary ratemaking procedures. A procedure to permit all or part of the construction work in progress (CWIP) to be included in the ratebase was adopted by the Federal Energy Regulatory Commission to alleviate the financial hardships with respect to construction programs awaiting completion. This adjustment allowed

\footnotetext{
${ }^{12}$ The accident at the Three Mile Island occurred on March 28, 1979. For factors leading to an escalation of nuclear power construction costs, see Energy Information Administration, An Analysis of Nuclear Power Plant Construction Costs, DOE/EIA-0485 (Washington, DC, March 1986), pp. ix-xvii.

${ }^{13}$ Energy Information Administration, Annual Energy Review 1992, DOE/EIA-0384(92) (Washington, DC, June 1993 ), p. 233.
} 
an electric utility to earn a cash return on investments embedded in the construction work in progress. ${ }^{14}$ The States also began adopting this procedure, and permitted the partial or complete inclusion of CWIP in the ratebase so that the utilities could earn a return on investments embedded in CWIP.

The State regulatory authorities responded to the increases in electricity costs with more critical cost reviews, disallowing some costs and introducing incentive programs based on performance. New cost recovery procedures were introduced for costly new power plants that would be added to a utility's ratebase. The costs were phased-in over a few years to reduce the resulting increase in electricity rates. Also, some costs were disallowed on the basis of prudence reviews.

Regulatory bodies also began making decisions on the recovery of costs expended on the construction of new coal-fired or nuclear power plants that were later canceled. The costs were usually allocated among utility ratepayers, investors, and either the State or the Federal government. ${ }^{15}$

By the mid-1980s, various factors began to contribute to the financial recovery of the electric utility industry. Important among them were: completion or cancellation of much of the ongoing construction activity; deceleration in the need for new power plant construction due to a marked and persistent decline in the growth rate for electric power; ${ }^{16}$ lower inflation; lower fossil fuel prices; and completion of the phase-in of the cost of many new plants into the ratebase. The cumulative impact of these factors was to aid and sustain the industry's recovery during the 1980 s. This process, for the most part, has been maintained during the early 1990s. The result is that the real price of electricity in 1992 was 23 percent less than the 1982 average price even though total electricity sales increased at a rate of 2.9 percent during this period, i.e., at a rate significantly lower than the historical growth rate discussed earlier.

In addition, the industry has also witnessed significant organizational and structural changes since the passage of the Public Utility Regulatory Policies Act of 1978 (PURPA) ${ }^{17}$ As will be discussed later, the passage of the Energy Policy Act of 1992 (EPACT) is likely to further accelerate the pace and direction of changes in the electric utility industry.

Electric utility ownership (within the traditional electric power industry group) is distributed among investorowned, publicly owned, cooperatives, and Federally owned utilities. About 3,200 firms or entities that make up the industry are characterized by a diversity in size, service area, fuel and generation mix, and financial resources (Table 3). These firms are engaged in the business of generating, transmitting and distributing power to various end-use sectors of the economy. At the end of 1992, the makeup of this traditional sector was: 262 investor-owned utilities (79 percent of utility electricity generation), 2,017 publicly owned utilities ( 8 percent of electricity generation), 943 cooperatives (5 percent of electricity generation), and 10 federally owned facilities (8 percent of electricity generation).

The investor-owned utilities, all with a corporate structure, are operated for profits and are financed by the equity contributions of the owners or by sale of debt in the financial markets. ${ }^{18}$ Though small in number, the investor-owned utilities overwhelmingly dominate the industry in terms of resources, especially with regard to installed generating capacity and the

\footnotetext{
${ }^{14}$ In the absence of this modification regarding the treatment of CWIP, the utilities were allowed to earn a non-cash return on investments in CWIP known as "allowance on funds used during construction." This procedure reduced the cash component of utility earnings and lowered its quality of earnings.

${ }^{15} \mathrm{As}$ an example, significant costs of the Shoreham nuclear plant were picked up by the State of New York. For further discussion with respect to earlier nuclear plants that were canceled, see Energy Information Administration, Nuclear Plant Cancellations: Causes, Costs, and Consequences, DOE/EIA-0392 (Washington, DC, April 1983).

${ }^{16}$ Installed nameplate capacity increased by 1.0 percent per year in 1985 through 1992 as compared to nearly 5.0 percent per year in 1970 through 1984.

${ }^{17}$ Energy Information Administration, The Changing Structure of the Electric Power Industry 1970-1991, DOE/EIA-0562 (Washington, DC, March 1993), pp. 3-13.

${ }^{18} \mathrm{~A}$ number of investor-owned utilities operate under the umbrella of a "holding company." As of December 31,1992, there were 11 electric holding companies registered with the Securities and Exchange Commission (SEC) controlling over 20 percent of the investorowned utilities. (Data aggregated from Securities and Exchange Commission, Financial and Corporate Report: Holding Companies Registered Under the Public Utility Holding Company Act of 1935 As of December 31, 1993 (Washington, DC, 1994).) Additionally, there were 49 holding companies exempt from SEC regulation by SEC order and 115 holding companies not subject to the Act, including both gas and electric utilities. (Data aggregated from Securities and Exchange Commission, Financial and Corporate Report: Holding Companies Exen. $p t$ From the Public Utility Holding Company Act of 1935 Under Section 3(a) and 3(a)(2) Pursuant to Rule 2 Filings or by Order As of November 1, 1993 (Washington, DC, 1994).) For a comprehensive discussion on the subject of holding companies, see Energy Information Administration, Public Utility Holding Company Act of 1935: 1935-1992, DOE/EIA-0563 (Washington, DC, January 1993).
} 
Table 3. Selected Electric Utility Data by Ownership, as of December 31, 1992

\begin{tabular}{|c|c|c|c|c|c|c|}
\hline Investor Owned & 262 & 85.79 & 573.0 & 167.05 & 2,112 & 2,214 \\
\hline Publicly Owned . . . . . . & 2,017 & 15.52 & 76.5 & 31.24 & 395 & 231 \\
\hline Cooperative & 943 & 11.95 & 26.1 & 24.10 & 207 & 127 \\
\hline Total $\ldots . . . \ldots$ & 3,232 & 113.28 & 741.7 & 229.88 & 2,763 & 2,797 \\
\hline
\end{tabular}

${ }^{a}$ Total number of consumers includes residential, commercial, industrial, public streets and highway lighting, and others.

b $T$ his does not include revenues from sales for resale.

'This does not include electricity sold for resale.

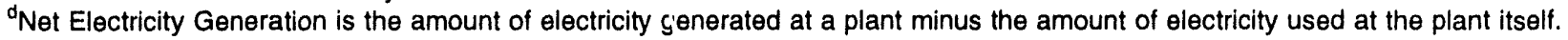

Note: Sum of components may not equal total due to independent rounding.

Sources: Number, Total Revenues From Electricity Sales. Electricity Sales-Energy information Administration, Financial Statistics of Major U.S. Investor-Owned Electric Utilities 1992, DOE/EIA-0437(92)/1 (Washington, DC, December 1993), p. 3. Total Number of Consumers, Net Electricity Generation-Energy Information Administration, Form EIA-861, "Annual Electric Utility Report." Nameplate Capacity-Energy Information Administration, Form ElA-860, "Annual Electric Generator Report."

associated output levels of electric power. As a result, they also account for nearly three-fourths of the total sales and revenues in the industry (Table 3 ).

The other segments of the industry consisting of Federal facilities, publicly owned utilities, and rural cooperatives are nonprofit institutions established to serve the communities and consumers at cost. As such, they are exempt from taxes and can secure financing at rates generally lower than those available to the investor-owned utilities.

Nonutility generation, before 1978 , was typically undertaken to meet demands of major industry groups such as the paper, chemical, mining and oil refining industries. Most of the power was produced through cogeneration, and the electricity was for the producers' own use with little or no opportunity for marketing any surplus power. ${ }^{19}$ The enactment of the PURPA aimed (among other objectives) to accelerate the commercial deployment of decentralized, small-scale electric power production (including those from renewable resources), cogeneration, and energy conservation. As a result, there has been an emergence of nontraditional elec- tricity-producing entities (called nonutility generators) since the mid-1980s. The PURPA legislation guaranteed a market for qualified decentralized facilities at an economic price calculated on the basis of a utility's full "avoided cost" - the marginal cost of electricity. Initial rulemaking, and the designation of a "qualifying facility" (QF) were entrusted to the Federal Energy Regulatory Commission. PURPA also provided QFs with exemptions from certain Federal and State regulations. In addition to QFs (which include small power producers and cogenerators), nonutility generators also include independent power producers (IPPs). These are power producers providing capacity and wholesale power to utilities under long-term power sales agreements.

At the end of 1992, 1,808 nonutilities accounted for nearly 57 gigawatts of installed generating capacity (Table 4). ${ }^{20}$ The entry of nonutility generators in the field of power generation has created an environment in which they have emerged as important power producers. However, potential changes in the industry structure that may result from the entry of nontraditional, nonutility power generators are not yet fully clear. ${ }^{21}$

\footnotetext{
${ }^{19}$ In addition to major industrial nonutility generators, there also exist small industrial producers. The generation of wood-fired electricity in the lumber industry is an example. Similar uses for residual byproducts can be found in the agricultural sector.

${ }^{20}$ Energy Information Administration, Electric Power Annual 1992, DOE/EIA-0348(92) (Washington, DC, January 1994), p. 122.

${ }^{21}$ For a fuller discussion of the possible changes of this development on the industry structure, see Energy Information Administration, The Changing Structure of Electric Power Industry, 1970-1991, DOE/EIA-0562 (Washington, DC, March 1993).
} 
Table 4. Capacity and Generation Statistics for the Nonutility Generating Sector, 1992 (Nonutility Data for Facilities of 1 or More Megawatts)

\begin{tabular}{|c|c|c|c|c|c|}
\hline $\begin{array}{l}\text { Installed Nameplate Capacity } \\
\text { by Type of Facility } \\
\text { (Gigawatts) }\end{array}$ & & $\begin{array}{l}\text { Installed Nameplate Capacity } \\
\text { by Type of Fuel } \\
\text { (Gigawatts) }\end{array}$ & & $\begin{array}{l}\text { Gross Generation } \\
\text { by Type of Fuel } \\
\text { (Blllion Kilowatthours) }\end{array}$ & \\
\hline Small Power Producer Qualifying Facility .. & 8.8 & Coal $^{b}$ & 8.5 & Coal ${ }^{b}$ & 47.36 \\
\hline Cogenerator Non-Qualifying Facility & 6.8 & Wood & 6.8 & Wood $^{c}$ & 36.26 \\
\hline Other Non-Quallifying Nonutilities & 5.4 & Waste ${ }^{d}$ & 3.0 & Waste $^{d}$ & 17.35 \\
\hline \multirow[t]{2}{*}{ Producer Qualifying Facility } & 0.6 & Geothermal $\ldots \ldots \ldots \ldots \ldots \ldots$ & 1.3 & Geothermal $\ldots \ldots \ldots \ldots \ldots$ & 8.58 \\
\hline & & Other & 0.6 & Other & 3.58 \\
\hline Total & 56.8 & Total & 56.8 & Total & 296.00 \\
\hline
\end{tabular}

ancludes petroleum, petroleum coke, diesel, kerosene, and petroleum sludge and tar. Also includes natural gas, butane, ethane, propane, waste heat, and waste gases.

bincludes coal, anthracite culm, and coal waste.

Includes wood, wood waste, peat, wood liquors, railroad ties, pitch and wood sludge.

IIncludes municipal solid waste, agricultural waste, straw, tires, landfill gases, and other gases.

- Includes nuclear reactor and generator at Argonne National Laboratory, hydrogen, sulfur, batteries, chemicals, and spent sulfite liquor.

Note: Sum of components may not equal total due to independent rounding.

Source: Capacity by Type of Facillty-Energy Information Administration, Form ElA-867, "Annual Nonutility Power Producer Report" for 1992 . Capacity and Generation by Tyr a of Fuel-Energy Information Administration, Electric Power Annual 1992, DOE/ElA-0348(92) (Washington, DC, January 1994 ), p. 119.

The recently enacted EPACT substantially revised the Federal regulation of the electric utility industry in order to increase the competition in wholesale electricity trade. Of the several provisions, one modifies the Public Utility Holding Company Act (PUHCA) by creating a new class of independent power producers, called "exempt wholesale generators" that are exempt from the corporate and geographic restrictions PUHCA imposes. Another allows public utility holding companies to own interest in IPP facilities. A third ensures that these and other wholesale power producers can obtain access to transmission facilities. ${ }^{22}$

Accordingly, the new class of independent power producers-the exempt wholesale power generators-are allowed to form corporate subsidiaries to develop and operate independent power projects anywhere in the United States. Exempt wholesale generators are not considered utilities under PUHCA: they can only sell their output at wholesale prices to electric utilities and municipalities. For this purpose, the exempt wholesale generators can also apply to the Federal Energy Regulatory Commission for an order requiring the electric utility to provide wheeling services. The Federal Energy Regulatory Commission is authorized to issue such orders provided the proposed transaction is in the public interest and meets the key criteria related to pricing, reliability, and self-dealing. ${ }^{23}$

The effect of the emergence of these nonutility power producers on the financial status of investor-owned utilities will be discussed later in this report. However, it is important to review and evaluate how the financial health for the investor-owned utilities changed in general during the period from 1981 through 1992.

\section{Financial Review of Investor-Owned Utilities}

Selected financial statistics (in the aggregate) of major investor-owned electric utilities for the 12-year period from 1981 through 1992 were compiled for this analysis (Table 5). ${ }^{24}$ The data include major investor-owned utilities, defined as those that in the past three

\footnotetext{
${ }^{22}$ Additional details are provided in Chapter 4.

${ }^{23}$ For additional information regarding nonutility generators, see Energy Information Administration, Electric Power Annual 1992, DOE/EIA-0348(92) (Washington, DC, January 1994), pp. 113-128.

${ }^{24}$ Summary and detailed financial accounting data on the investor-owned segment of the domestic electric utility industry are presented in Energy Information Administration, Financial Statistics of Major U.S. Investor-Owned Electric Utilities 1992, DOE/EIA-0437(92)/1 (Washington, DC, December 1993), pp. 16-23. These statistics are compiled annually by the Energy Information Administration from the Federal Energy Regulatory Commission (FERC) Form 1, "Annual Report of Major Electric Utilities, Licensees and Others."
} 
Table 5. Composite Financial Statistics for Investor-Owned Electric Utilities, 1981-1992 (Billion Dollars)

\begin{tabular}{|c|c|c|c|c|c|c|c|c|c|c|c|c|}
\hline \multirow[b]{2}{*}{ Item } & \multicolumn{12}{|c|}{ Year } \\
\hline & 1981 & 1982 & 1983 & 1984 & 1985 & 1986 & 1987 & 1988 & 1989 & 1990 & 1991 & 1992 \\
\hline \multicolumn{13}{|l|}{ Income Statement } \\
\hline Electric Operating Revenues & 101.78 & 109.38 & 116.69 & 128.27 & 135.27 & 136.26 & 138.55 & 143.93 & 150.90 & 157.28 & 166.80 & 169.49 \\
\hline Electric Operating Expenses & 85.56 & 91.24 & 96.22 & 105.50 & 111.13 & 110.17 & 111.56 & 115.35 & 121.55 & 127.90 & 135.95 & 139.01 \\
\hline Net Electric Operating Income & 16.22 & 18.14 & 20.47 & 22.76 & 24.14 & 26.09 & 26.99 & 28.58 & 29.35 & 29.38 & 30.86 & 30.48 \\
\hline Net Utility Operating Income & 17.00 & 19.09 & 21.43 & 23.95 & 25.33 & 27.23 & 28.08 & 29.76 & 30.57 & 30.53 & 32.09 & 31.81 \\
\hline Total Other Income (net) & 4.67 & 5.71 & 6.80 & 7.24 & 7.61 & 6.98 & 5.52 & 2.04 & 2.56 & 1.83 & 0.52 & 1.69 \\
\hline Net Interest Charges. & 9.00 & 9.75 & 10.34 & 11.48 & 12.58 & 13.48 & 13.62 & 14.39 & 14.85 & 15.74 & 15.74 & 15.22 \\
\hline \multicolumn{13}{|l|}{ Income Before Extraordinary } \\
\hline Items & 12.66 & 15.05 & 17.89 & 19.72 & 20.36 & 20.72 & 19.98 & 17.41 & 18.28 & 16.62 & 16.88 & 18.28 \\
\hline Net Income & 12.71 & 15.14 & 17.67 & 19.70 & 18.70 & 20.42 & 19.02 & 16.04 & 17.31 & 16.90 & 16.95 & 18.38 \\
\hline \multicolumn{13}{|l|}{ Dividends Declared } \\
\hline Preferred & 2.25 & 2.51 & 2.78 & 2.86 & 2.96 & 2.65 & 2.30 & 2.26 & 2.42 & 2.03 & 1.95 & 2.04 \\
\hline
\end{tabular}

\section{Balance Sheet}

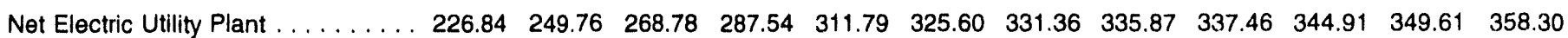

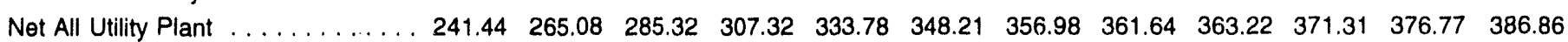
Total Other Property and

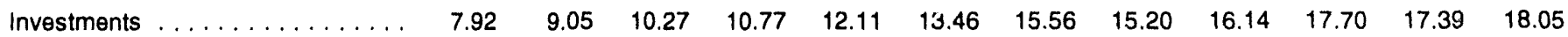

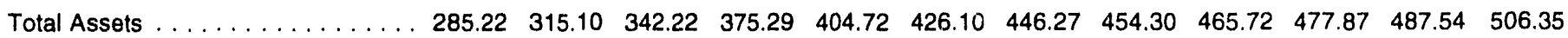

\begin{tabular}{|c|c|c|c|c|c|c|c|c|c|c|c|c|}
\hline II Preterrea vedusto & 26.55 & 28.33 & 29.78 & 30.30 & 30.02 & 28.37 & 26.76 & 26.37 & 25.94 & 25.62 & 25.26 & 25.54 \\
\hline otal Common Equity ${ }^{a}$ & 87.19 & 99.08 & 110.63 & 120.93 & 131.46 & 139.05 & 142.93 & 142.72 & 145.18 & 147.42 & 151.67 & 156 \\
\hline Total Long-Term Debt & 115.26 & 124.06 & 131.57 & 140.58 & 152.66 & 157.21 & $158.4 \%$ & 160.73 & 162.95 & 167.94 & $171.8 j$ & 174 \\
\hline Total Capitalization & 229.01 & 251.47 & 271.97 & 291.81 & 314.14 & 324.63 & 328.11 & 329.81 & 334.07 & 340.98 & 348.83 & 356. \\
\hline otal Liabilities and Equity. & 285.22 & 315.10 & 342.22 & 375.29 & 404.72 & 426.10 & 446.27 & 454.30 & 465.72 & 477.87 & 487.54 & 506. \\
\hline
\end{tabular}

Cash Flow Statement ${ }^{b}$

Net Income

Depreciation, Depletion, and

Amortization ............... 8

Deferred Taxes (net) ${ }^{c} \ldots \ldots \ldots \ldots$
Less: Allowance for Funds

Used During Construction ... . . . 5

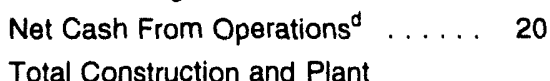

Expenditures $^{\theta} \ldots \ldots \ldots \ldots \ldots 28$

Cash Provided by Outside

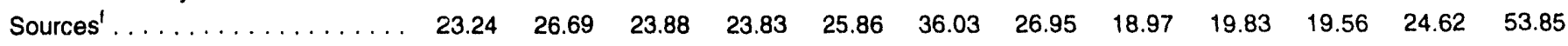

Net Cash Provided by Financing

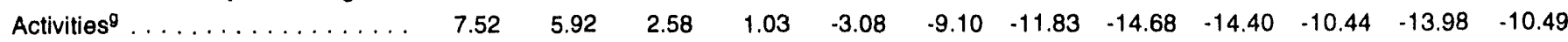

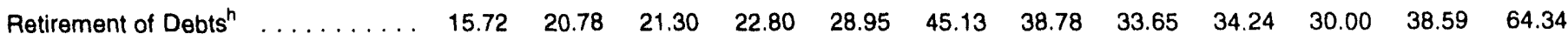

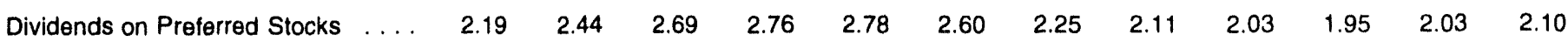

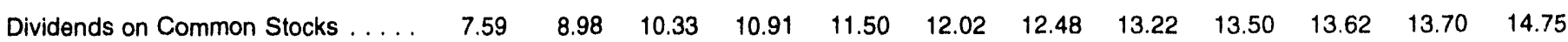

See footnotes at end of table. 
Table 5. Composite Financial Statistics for Investor-Owned Electric Utilities, 1981-1992 (Continued)

\begin{tabular}{|c|c|c|c|c|c|c|c|c|c|c|c|c|}
\hline Item & \multicolumn{12}{|c|}{ Year } \\
\hline \multicolumn{13}{|l|}{ Electric Operating Revenues/Total } \\
\hline Operating Revenues $\ldots \ldots \ldots$ & 86.5 & 85.6 & 85.9 & 86.7 & 87.4 & 89.2 & 90.2 & 90.2 & 90.3 & 90.9 & 91.4 & 91.2 \\
\hline \multicolumn{13}{|l|}{ Total Electric Operating Expenses/ } \\
\hline \multicolumn{13}{|l|}{ Net Electric Operating Income/ } \\
\hline Electric Operating Revenues & 15.9 & 16.6 & 17.5 & 17.7 & 17.8 & 19.1 & 19.5 & 19.9 & 19.5 & 18.7 & 18.5 & 18.0 \\
\hline \multicolumn{13}{|l|}{ Percent of Earnings Available for } \\
\hline Common Stock . . . . . . . . . & 74.5 & 72.6 & 70.6 & 66.7 & 75.6 & 70.9 & 77.4 & 98.1 & 94.2 & 95.4 & 96.2 & 91.1 \\
\hline Return on Common Stock Equity ... & 15.3 & 16.2 & 16.9 & 21.9 & $: 2.3$ & 15.1 & 13.5 & 11.2 & 12.0 & 11.5 & 11.3 & 12.0 \\
\hline
\end{tabular}

${ }^{a}$ Calculated from the Composite Balance Sheet as Total Proprietary Capital ninus Total Preferred Stock.

b 1986 and 1987 values are published estimates. 1981 through 1985 values are obtained or calculated from published values in the Statement of Changes in Financial Position and the Composite Balance Sheet since the Siatement of Cash Flows was not published for those years.

${ }^{c}$ This item is labeled Future Income Taxes (net) on the Statement of Changes in Financial Position.

${ }^{d}$ Total Funds From Operations were used for 1981 through 1985 from the Statement of Changes in Financial Position.

${ }^{\theta}$ For 1989 through 1992 this value is taken as Cash Outlows for Plant from the Composite Statement of Cash Flows.

'Includes proceeds from issuance of long-term debt, preferred stock, common stock, other, and net increase in short term debt. For 1981 through 1985, this value is calculated from the Statement of Changes in Financial Position as Total Funds from Outside Sources.

${ }^{9}$ For 1981 through 1985 this is calculated from the Statement of Changes in Financial Position by subtracting Total Payments for Retirement of Debts/Stocks and Dividend Payments from Total Funds From Outside Sources.

hIncludes payment for retirement of long-term debt, stock purchases, changes in short-term debt, and other liabilities.

'Calculations for 1988 and after were derived from the Statement of Cash Flows. Calculations for prior yeiars were derived from the Statement of Changes in Financial Position.

Sources: 1981-1985-Energy Information Administration, Financial Statistics of Selected Electric Utilities 1985, DOE/ElA-0437(85) (Washington, DC, January 1987), pp. 12-26. 1986-1990-Energy Information Administ.ation, Financial Statistics of Selected Investor-Owned Electric Utilities 1990, DOE/EIA 0437(90)/1 (Washington, DC, January 1992), pp. 12-19. 1991-1992_Energy Information Administration, Financial Statistics of Major U.S. Investor-Owned Electric Utilities 1992, DOE/EIA-0437(92)/1 (Washington, DC, December 1993), pp. 16-23.

consecutive calendar years, have had sales or transmission services that exceeded one or more of the following:

- 1 million megawatthours of total annual sales

- 100 megawatthours of annual sales for resale

- 500 megawatthours of annual power exchanges delivered

- 500 megawatthours of wheeling for others (deliveries plus losses).

This classification scheme has been current since 1984, ensuring the consistency of data for the 1984-1992 period ${ }^{25}$ For the period 1981-1983, the then prevailing classification scheme included investor-owned utilities in categories " $A$ " (investor-owned utilities with annual operating revenues of $\$ 2.5$ million or more) and " $\mathrm{B}$ " (investor-owned utilities with operating revenues of $\$ 1$ million or more but less than $\$ 2.5$ million). Selected financial data for the period 1981-1983, presented in various tables in this section, have been appropriately modified to reflect the 1984 universe. ${ }^{26}$

One more data issue needs clarification. Due to changes in reporting required under FERC Order No. 505 (issued on October 13, 1988), investor-owned utilities substituted the "Statement of Changes in Financial

\footnotetext{
${ }^{25}$ The 1992 data (as shown in Table 5) are based on reports from 180 major investor-owned utilities. Six independent power producers found to be under FERC jurisdiction are required to provide information on FERC Form 1. In addition, two electric cooperatives (falling under section 201 of the Federal Power Act) are also required to submit data on FERC Form 1. For additional information, see Financial Statistics of the Major U.S. Investor-Owned Electric Utilities, DOE/EIA-0437(92)/1 (Washington, DC, December 1993).

${ }^{26}$ See Energy Information Administration, Financial Statistics of Selected Electric Utilities 1984, DOE/EIA-0437(84) (Washington, DC, January 1986), p. vii.
} 
Position" submitted in the prior years with the "Statement of Cash Flows" starting with the 1988 submission. The "Statement of Cash Flows" data were published by the EIA for the first time in 1988 in the Financial Statistics of Selected Electric Utilitics 1988. For purposes of comparison, data on "Changes in Financial Position" for the years 1986 and 1987 were also estimated to approximate the new submission requirements, i.e., the "Statement of Cash Flows." The methodology then developed to accomplish this approximation has been utilized to derive certain elements (pertaining to the "Statement of Cash Flows" elements) for the period 1981 through 1985.

In addition to selected financial data (for the major investor-owned utilities) for the period from 1981 to 1992 , some income account ratios (derived from financial data) that are relevant to analysts are also included in Table 5.

\section{Operating Revenues and Expenses}

Overall, electric operating revenues exhibited a healthy growth from $\$ 101.8$ billion in 1981 to $\$ 169.5$ billion in 1992 (Figure 1). This translates into an impressive average annual growth rate of 4.7 percent. Computation of an average growth rate, however, masks variations from one year to another. The percentage change in electric operating revenues from one year to another, ranges from a high of nearly 17 percent in 1981 to a low of 0.7 percent in 1986 (Figure 2). The rate of growth in electric operating revenues from 1981 through 1985 is a robust average annual rate of 7.4 percent. The next 2 years (i.e., in 1986 and 1987) exhibit a lackluster performance with revenue levels only marginally above the 1985 level. The next 5 years from 1987 through 1992 experienced an average annual growth of 4.1 percent.

The unusually high growth in electric operating revenues in 1981 resulted from a significant increase in electricity retail prices in comparison with the prices that prevailed in 1980. Residential sector prices increased by 14.8 percent; those in the commercial and industrial sectors increased by 14.5 and 16.2 percent, respectively, over the 1980 retail electricity prices. ${ }^{27}$ In
Figure 1. Electric Operating Revenues, 1981-1992

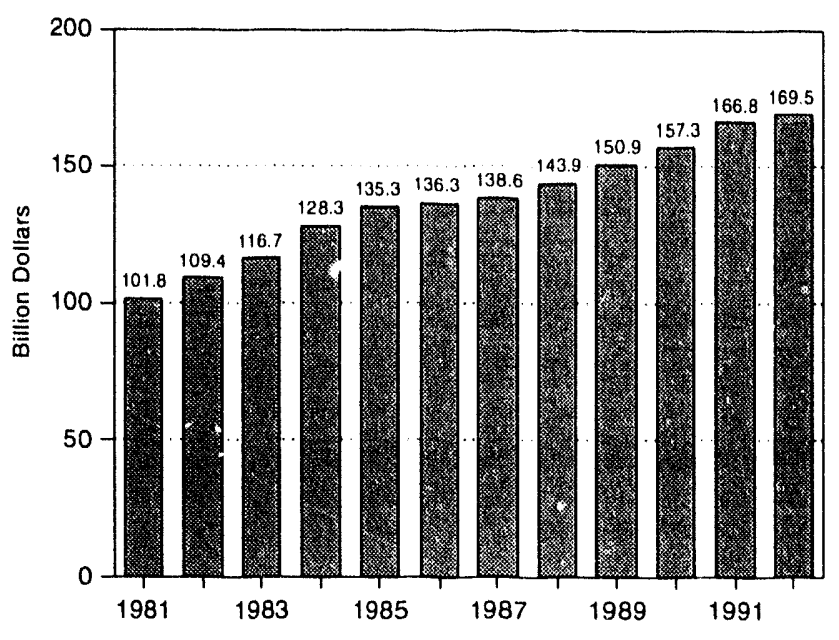

Source: Energy Information Administration, Financial Statistics of Major U.S. Investor-Owned Electric Utilities 1992, DOE/EIA-0437(92)/1 (Washington, DC, December 1993), pp. 16-23, and predecessor publications.

addition, aggregate end-use sales were up by 2.5 percent in 1981. The cumulative impact of these two factors was to boost the revenues by almost 17 percent in 1981.

The sluggish growth in operating revenues during 1986 and 1987 and the modest growth in most of the subsequent years may be attributed primarily to the near stable prices for electricity. Nominal retail electricity prices increased from 6.4 cents per kilowatthour in 1985 to 6.8 cents per kilowatthour in 1992, i.e., at a rate of about 1 percent per year (Figure 3). ${ }^{28}$ Aggregate enduse electricity sales also increased by about 2.5 percent per year, from 2,324 billion kilowatthours in 1985 to 2,763 billion kilowatthours in 1992 (Table 2). As a result, aggregate revenues increased by 3.3 percent duririg this period.

Quite a different set of factors prevented an escalation in operating expenses. ${ }^{29}$ Lower interest rates, decreasing or stable fossil fuel prices, ${ }^{30}$ reduction in corporate income taxes (brought about by the Tax Reform Act of 1986), and completion of construction

\footnotetext{
${ }^{27}$ Energy Information Administration, Annual Energy Review 1990, DOE/EIA-(0384 (Washington, DC, May 1991), Table 100, p. 225.

${ }^{28}$ Retail electricity prices in constant 1987 dollars declined from 6.8 cents per kilowatthour in 1985 to 5.6 cents per kilowatthour in 1992 (Figure 3).

${ }^{29}$ Utility operating expenses include: operation and maintenance expenses, depreciation, amortization, taxes, provision for deferred taxes, investment tax credit adjustments, and gains/losses from disposition of electric utility plant.

${ }^{31}$ Real fossil fuel prices (consisting of crude oil, natural gas and coal) -in constant 1987 dollars-declined from $\$ 3.48$ per million Btu in 1981 to $\$ 1.70$ per million Btu in 1987 and to $\$ 1.41$ per million Btu in 1992. In other words, during the period 1981-1992, real fossil fuel prices declined by 60 percent. For fuel-specific price information, see Energy Information Administration, Annual Energy Review 1992, DOE/EIA-0384(92) (Washington, DC, June 1993), pp. 69-71. Also, Table 1 shows changes in interest rates during this period.
} 
Figure 2. Annual Percentage Changes in Electric Operating Revenues from Previous Year, $1981-1992^{a}$

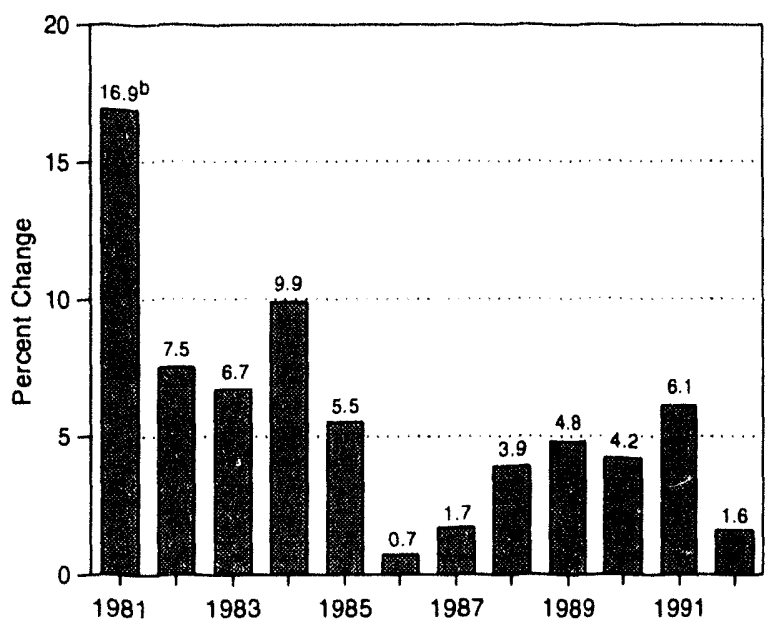

${ }^{a}$ See Figure 1 for electric operating revenues.

bElectric operating revenues in 1980 were $\$ 87.06$ billion.

Source: Energy Information Administration, Financial Statistics of Major U.S. Investor-Owned Electric Utilities 1992, DOE/EIA-0437(92)/1 (Washington, DC, December 1993), pp. 16-23, and predecessor publications.

programs contributed to holding the line on expenses and to a modest but sustained improvement in net operating income (which is the difference between operating revenues and operating expenses). As a result, operating expenses as a share of operating revenues (during the 1988-1992 period) declined gradually since 1981. In 1981 through 1985, operating expenses absorbed about 83 percent of operating revenues, leaving about 17 percent as net operating income (Figure 4). In contrast, the share of the residual operating income averaged about 19 percent during the 1988-1992 period, reflecting over a 10 percent improvement over the 1981-1985 period. As discussed in the next section, this development assisted in significantly improving the quality of utility earnings.

\section{Improvements in the Quality of Earnings}

A closer examination of the data reveal a significant improvement in the quality of electric utility earnings in 1988 through 1992, as compared to the financially troubled period of the late 1970s and early 1980s. Apart from the improvement in the economy, the major contributory factor was the continuing decline in new power plant construction during the period.

\section{Figure 3. Real $\left.\right|^{a}$ and Nominal Retail Prices of Electricity Sold by Electric Utilities, 1981-1992}

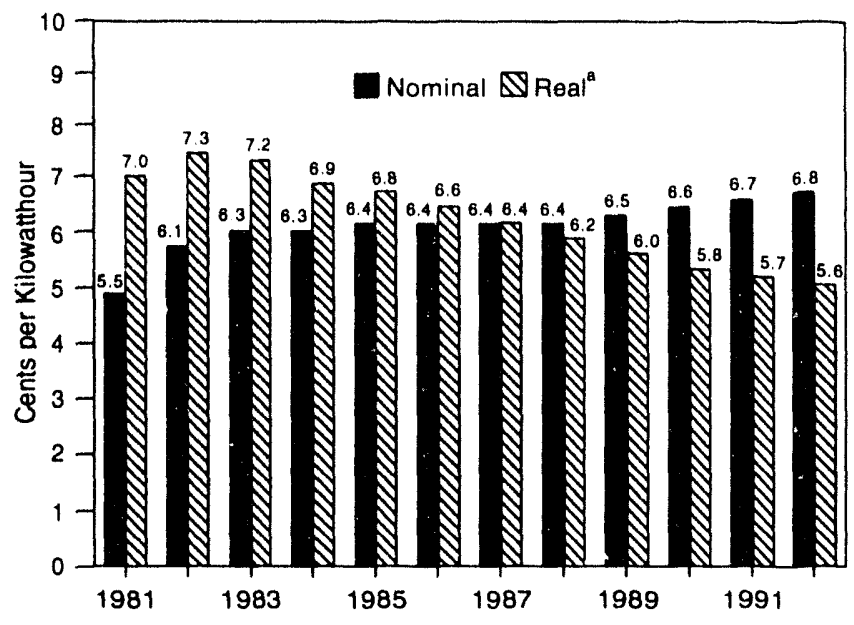

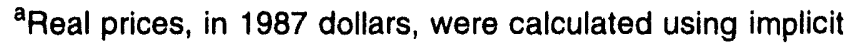
GDP price deflators.

Source: Energy Information Administration, Annual Energy Review 1992, DOE/EIA-0384(92) (Washington, DC, June 1993), p. 233.

Thie industry was in the midst of a massive construction program during the 1970 s designed to meet the then projected growth in electricity demand. Regulatory authorities permit utilities to recover the construction costs of new plants only upon their completion when they are placed in service. The cost of the plant, including any unrecovered finance charges, is then recovered through an annual depreciation expense over the economic life of the plant. In addition, the utility is allowed to earn a return on the undepreciated balance. Delays in the completion of plants and the associated increases in costs, along with the large amount of capacity under construction, resulted in increasing levels of costs for construction work in progress that were accruing until plants were completed.

While investments in construction work in progress do not produce any income during the period of construction, carrying charges in the form of dividend and interest payments still have to be made annually. ${ }^{31}$ These items appear as expenses on the utility's income statement. Accounting procedures require that an amount equal to the net cost of borrowed funds and an appropriate rate of return on equity funds be added to the revenue or income side to balance these expenses. When the project is completed and the plant is placed

${ }^{31}$ The type of payment, i.e., dividend or interest, depends on whether the financing for the project is from internal or external sources. 
Figure 4. Net Electric Operating Income as a Share of Electric Operating Revenues, 1981-1992

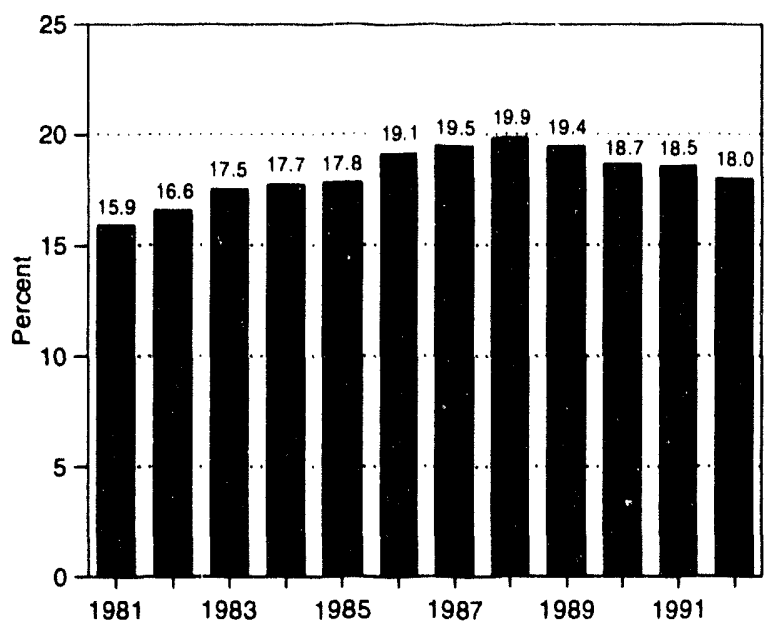

Source: Energy Information Administration, Financial Statistics of Major U.S. Investor-Owned Electric Utilities 1992, DOE/EIA-0437(92)/1 (Washington, DC, December 1993), pp. 16-23, and predecessor publications.

in service, the cost to be recovered is made up of the construction costs and an allowance for funds used during construction (AFUDC) that were previously reported as annual income. This accounting prccedure is a technique used to capitalize and thus defer recovery of the cost of funds used in financing construction projects.

Since the AFUDC reported on the utility's annual income statement represents noncash income, the operational impact of this procedure is to reduce the cash component of the investor-owned utility's earnings, leading to a dilution in the quality of earnings. During the 1980s, regulatory procedures regarding AFUDC began to change, and some States allowed util- ities to recover partial or total annual financing charges on construction work in progress as they occurred. This modification, as indicated earlier, was also supported by the Federal Energy Regulatory Commission.

In 1981, the accumulated cost of construction work in progress for plants that had not been completed totaled $\$ 69.4$ billion, representing 23.8 percent of total electric utility plant or 42.9 percent of net electric utility plant $^{32}$ (Table 6). On this outlay, AFUDC accruals were $\$ 5.2$ billion, representing over 41.3 percent of net income in that year (Figure 5). The accumulated costs for construction work in progress peaked at $\$ 90.9$ billion in 1984 and have declined each year thereafter through 1991 primarily due to completion of plants under construction and declining levels of new construction activity. At the end of 1992, construction work in progress costs stood at $\$ 20.6$ billion claiming about $\$ 1.2$ billion in AFUDC accruals or about 6.4 percent of net reported income (Figure 5 and Table $6)^{33}$

The investment community generally takes the view that the higher the percentage of AFUDC as a share of the net income, the poorer is the quality of earnings. Accordingly, a decline in the ratio of AFUDC accruals relative to net reported income since the mid-1980s represents an improvement in liquidity and in the quality of earnings over time.

Declining construction work in progress levels eased pressures on external funding requirements, tending to keep interest payment obligations from increasing (Table 7). This trend was further tempered by the state of the economy and the declining interest rates since the mid-1980s. ${ }^{34}$ Taken together, the combination of these influences has led to an improvement in the interest coverage ratios, making it possible for some utilities to sell their debts in the market at rates that were more favorable than before. ${ }^{35}$

\footnotetext{
${ }^{32}$ Net electric utility plant represents the value of the plant after accounting for depreciation to date.

${ }^{33}$ The above information can also be viewed from another perspective. As seen from Table 6, outstanding construction work in progress as a share of the net electric utility plant declined from a high of 48.3 percent in 1983 to 6.0 percent in 1992 (as a share of the total utility plant, the corresponding decline is from 25.6 percent in 1983 to 3.8 percent in 1992).

${ }^{34}$ Real gross domestic product increased at an average annual rate of 3.8 percent from 1982 to 1987 , followed by a 1.9 percent average annual growth rate during the 1987-1992 period. For the 1982-1992 period, the average annual growth rate works out to 2.8 percent. (Economic growth rates have been computed.) The bank prime rate declined from 18.87 percent in 1981 to 6.25 percent in 1992 . See Council of Economic Advisers, Economic Report of the President (U.S. Government Printing Office, Washington, DC, February 1994), pp. 270-271 and 352-353.

${ }^{35}$ The present decline in interest coverage ratios has become the subject of a debate. It is contended that investor-owned utilities with significant power purchases from nonutility generators are likely to confront an erosion of their credit ratings in the market (due to a decline in their coverage ratios) unless their equity levels can also be increased commensurately. The nature of the debate and its impact are discussed later in this report.
} 
Table 6. Outstanding Electric Construction Work in Progress as a Share of Total or Net Electric Utility Plant for Major Investor-Owned Electric Utilities, 1970-1992

\begin{tabular}{|c|c|c|c|c|c|c|}
\hline & Year $^{a}$ & $\begin{array}{l}\text { Construction } \\
\text { Work in } \\
\text { Progress } \\
\text { (CWIP) } \\
\text { (Billion Dollars) }\end{array}$ & $\begin{array}{c}\text { Total } \\
\text { Electric Utility } \\
\text { Plant } \\
\text { (Billion Dollars) }\end{array}$ & $\begin{array}{l}\text { CWIP/Total } \\
\text { Electric Utility } \\
\text { Plant } \\
\text { (Percent) }\end{array}$ & $\begin{array}{c}\text { Net } \\
\text { Electric } \\
\text { Utility Plant } \\
\text { (Billion Dollars) }\end{array}$ & $\begin{array}{c}\text { CWIP/ } \\
\text { (Net Electric } \\
\text { Utility Plant-CWIP) } \\
\text { (Percent) }\end{array}$ \\
\hline 1970 & $\ldots \ldots \ldots \ldots \ldots$ & 10.3 & 92.9 & 11.1 & 72.7 & 16.5 \\
\hline 1971 & $\ldots \ldots \ldots \ldots \ldots$ & 13.5 & 103.4 & 13.1 & 81.8 & 19.8 \\
\hline 1972 & $\ldots \ldots \ldots \ldots$ & 16.6 & 115.6 & 14.4 & 92.2 & 22.0 \\
\hline 1973 & $\ldots \ldots \ldots \ldots \ldots$ & 20.3 & 129.6 & 15.6 & 104.0 & 24.3 \\
\hline 1974 & $\ldots \ldots \ldots \ldots \ldots$ & 22.8 & 144.5 & 15.8 & 117.1 & 24.2 \\
\hline 1975 & $\ldots \ldots \ldots \ldots$ & 26.3 & 158.8 & 16.6 & 128.8 & 25.7 \\
\hline 1976 & $\ldots \ldots \ldots \ldots$ & 31.7 & 174.8 & 18.1 & 142.0 & 28.7 \\
\hline 1977 & $\ldots \ldots \ldots \ldots \ldots$ & 36.5 & 193.2 & 18.9 & 157.0 & 30.3 \\
\hline 1978 & $\ldots \ldots \ldots \ldots$ & 42.5 & 213.3 & 19.9 & 173.5 & 32.4 \\
\hline 1979 & $\ldots \ldots \ldots \ldots \ldots$ & 54.0 & 236.5 & 22.8 & 192.6 & 39.0 \\
\hline 1980 & $\ldots \ldots \ldots \ldots \ldots$ & 60.4 & 260.3 & 23.2 & 211.5 & 40.0 \\
\hline $19 \varepsilon 1$ & $\ldots \ldots \ldots \ldots$ & 69.4 & 291.8 & 23.8 & 231.2 & 42.9 \\
\hline 1982 & $\ldots \ldots \ldots \ldots$ & 82.0 & 321.3 & 25.5 & 253.7 & 47.8 \\
\hline 1983 & $\ldots \ldots \ldots \ldots \ldots$ & 89.1 & 348.0 & 25.6 & 273.6 & 48.3 \\
\hline 1984 & $\ldots \ldots \ldots \ldots \ldots$ & 90.9 & 377.1 & 24.1 & 295.2 & 44.5 \\
\hline 1985 & $\ldots \ldots \ldots \ldots$ & 84.0 & 411.2 & 20.4 & 320.4 & 35.5 \\
\hline 1986 & $\ldots \ldots \ldots \ldots$ & 75.3 & 434.7 & 17.3 & 334.2 & 29.1 \\
\hline 1987 & $\ldots \ldots \ldots \ldots \ldots$ & 51.0 & 452.6 & 11.3 & 341.7 & 17.5 \\
\hline 1988 & $\ldots \ldots \ldots \ldots \ldots$ & 40.3 & 468.3 & 8.6 & 345.5 & 13.2 \\
\hline 1989 & $\ldots \ldots \ldots \ldots$ & 33.7 & 481.6 & 7.0 & 346.2 & 10.8 \\
\hline 1990 & $\ldots \ldots \ldots \ldots \ldots$ & 22.6 & 500.2 & 4.5 & 352.7 & 6.8 \\
\hline 1991 & $\ldots \ldots$ & 18.1 & 518.5 & 3.5 & 356.5 & 5.3 \\
\hline 1992 & $\ldots \ldots \ldots \ldots \ldots$ & 20.6 & 538.6 & 3.8 & 365.1 & 6.0 \\
\hline
\end{tabular}

aData as of December 31 for each year.

Source: Energy Information Administration, Financial Statistics of Major U.S. Investor-Owned Electric Utilities 1992, DOE/EIA-0437(92)/1 (Washington, DC, December 1993), p. 42, and predecessor publications.

There is yet another element which moderately affected the quality of earnings in the same fashion as did the AFUDC accruals. One would normally expect that the accumulated costs of a prudently completed power plant would begin to be recovered by a utility upon completion. However, when a newly completed plant is expensive (as was the case for some nuclear power plants that were completed in the 1980s), the resulting rate increase may not be acceptable to the consumers. Regulators, therefore, introduced a procedure called "ratebase phase-in," whereby the cost of the plant was added to the utility's ratebase in increments over several years, resulting in a more gradual rise in consumer prices. As an example, 50 percent of the total costs of a new plant may immediately be added to the ratebase, leaving the remainder to be included in the following years. The amount thus excluded from the ratebase is, however, permitted to earn the allowed return similar to AFUDC accruals. Most of the phase-in plans initiated during the 1980 s have since been completed. Accordingly, the industry-wide impact of phase-ins currently is at a minimum. ${ }^{36}$

\footnotetext{
${ }^{36} \mathrm{At}$ the end of 1992 , the outstanding amounts for phase-in were reported to be $\$ 173$ million, down from $\$ 1.05$ billion in 1989 . See Edison Electric Institute, 1992 Financial Review-Annual Report of the Investor-Owned Electric Utility Industry (Washington, DC, July 1993), pp. 8-11, and Energy Information Administration, Financial Analysis of Investor-Owned Electric Utilities, DOE/EIA-0499 (Washington, DC, November 1986), pp. 32-34.
} 
Figure 5. Allowance for Funds Used During Construction as a Component of Net Income of Major Investor-Owned Electric Utilities, 1981-1992

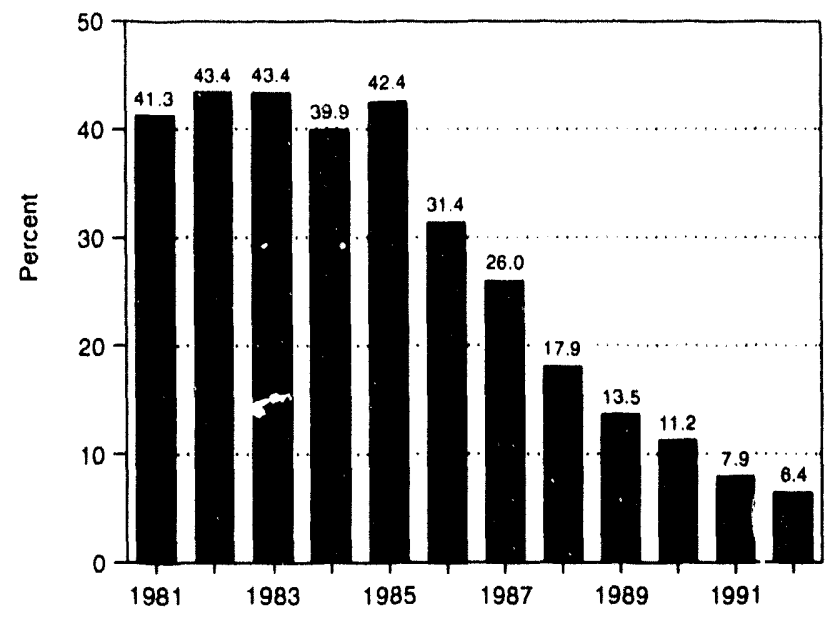

Source: Energy Information Administration, Financial Statistics of Major U.S. Investor-Owned Electric Utilities 1992, DOE/EIA-0437(92)/1 (Washington, DC, December 1993), pp. 16-23, and predecessor publications.

\section{Capitalization Adjustments}

The capital structure of the investor-owned utilities is usually characterized by a larger proportion of debt and preferred stock, making it highly leveraged, during the 1970s. Long-term debt invariably provided more than 50 percent of the capital (Table 8 ). An additional 10 to 12 percent was provided by the sale of preferred stocks. Thus, the share of common equity (inclusive of retained earnings) was around 35 to 37.5 percent of the capital structure during the 1970 s.

Over the years "conventional" debt loan limits have developed for investor-owned utilities that are tied to bond-ratings. A bond-rating agency, like Standard and Poor's, goes beyond the balance sheet to evaluate quasidebt items and elements of hidden financial leverage. ${ }^{37}$ Non-capitalized leases, sale/leaseback obligations, debt guarantees, receivable sales, and certain purchased power contracts are all considered debt equivalents in calculating capitalization ratios. Inclusive of these el- ements, Standard and Poor's would currently give an AA rating to an investor-owned utility if its capitalization had less than 46 percent of debt. An investorowned utility exceeding 50 percent of debt may be allocated a bond-rating of $\mathrm{BBB}$ or its lowest rating of $\mathrm{BB}$ if the debt component exceeded 62 percent. $^{38}$ The Securities and Exchange Commission seems to favor debt limits in the neighborhood of 50 percent. ${ }^{39}$ Accordingly, the investor-owned utilities generally strive to adhere to debt ratios at or below 50 percent to the extent possible.

In establishing a capital structure, the choice between debt and equity financing has an impact on income per share, risk, control, and flexibility. Adding debt to a firm's capital structure (due to tax-deductibility of interest on debt) may well increase the per-share level of earnings, but it also raises the possibility of increased riskiness. ${ }^{40}$ Within the investment community, the higher the degree of debt utilization in a firm's capitalization, the higher is the degree of risk faced by suppliers of debt given the resulting increase in its fixed payment obligations. To compensate the suppliers of debt under such conditions, a higher rate of return is consequently demanded as debt utilization expands. Equity suppliers also perceive this risk and demand a higher rate of return. In other words, the fixed obligation of debt leads both the suppliers of debt and equity to demand higher rates of return as the portion of debt in total capitalization increases. ${ }^{41}$

The early 1980s witnessed unprecedented increases in interest rate levels. The prime rate charged by banks increased from 5.25 percent in 1972 to 18.87 percent in 1981 (Table 1). The corporate bond rates also moved up to a high of 14.17 in 1981. As a result, the average cost of debt sales (by the investor-owned utilities as a whole) increased as new debts were sold or the older low interest-bearing bonds were replaced with the higher prevailing rates of interest. The embedded cost of debt for the industry increased from 5.23 percent in 1970 to 9.76 percent in 1982 and to 9.98 percent in 1985 (Table 7), causing the overall debt-interest payments to increase. Interest charges payable by the investorowned utilities in the aggregate increased from $\$ 9.6$ billion in 1980 to $\$ 15.6$ billion in 1985 (or by about 60 percent), while the long-term debt of the investorowned utilities increased from $\$ 105.3$ billion to $\$ 152.7$ billion (or by about 45 percent) during the same period.

\footnotetext{
${ }^{37}$ Other bond-rating agencies also follow a similar procedure. Chapter 4 provides additional details.

${ }^{34}$ See Standard and Poor's Electric, Gas \& Water Utilities Review (New York, October 1992), p. 12

${ }^{34}$ See Paul J. Carfield and Wallace J. Lovejoy, Public Utility Economics (Englewood Cliffs, NJ: Prentice-Hall, Inc., 1964$)$, p. 420.

${ }^{4}$ For a detailed analysis of the implications of tax-deductibility of interest charges on corporate debt, see Alan C. Shapiro, Modern Corporate Finunce (New York, NY: McMillan Publishing Co., 1990), pp. 422-449.

${ }^{11}$ See H. Bierman and Jerome E. Hass, An Introduction to Managerial Finance (New York, NY: W.W. Norton \& Co, 1973 ), pp. 93-109.
} 
Table 7. Total Debt of Major Investor-Owned Utilities and Interest Coverage Ratios, Selected Years, 1970-1992

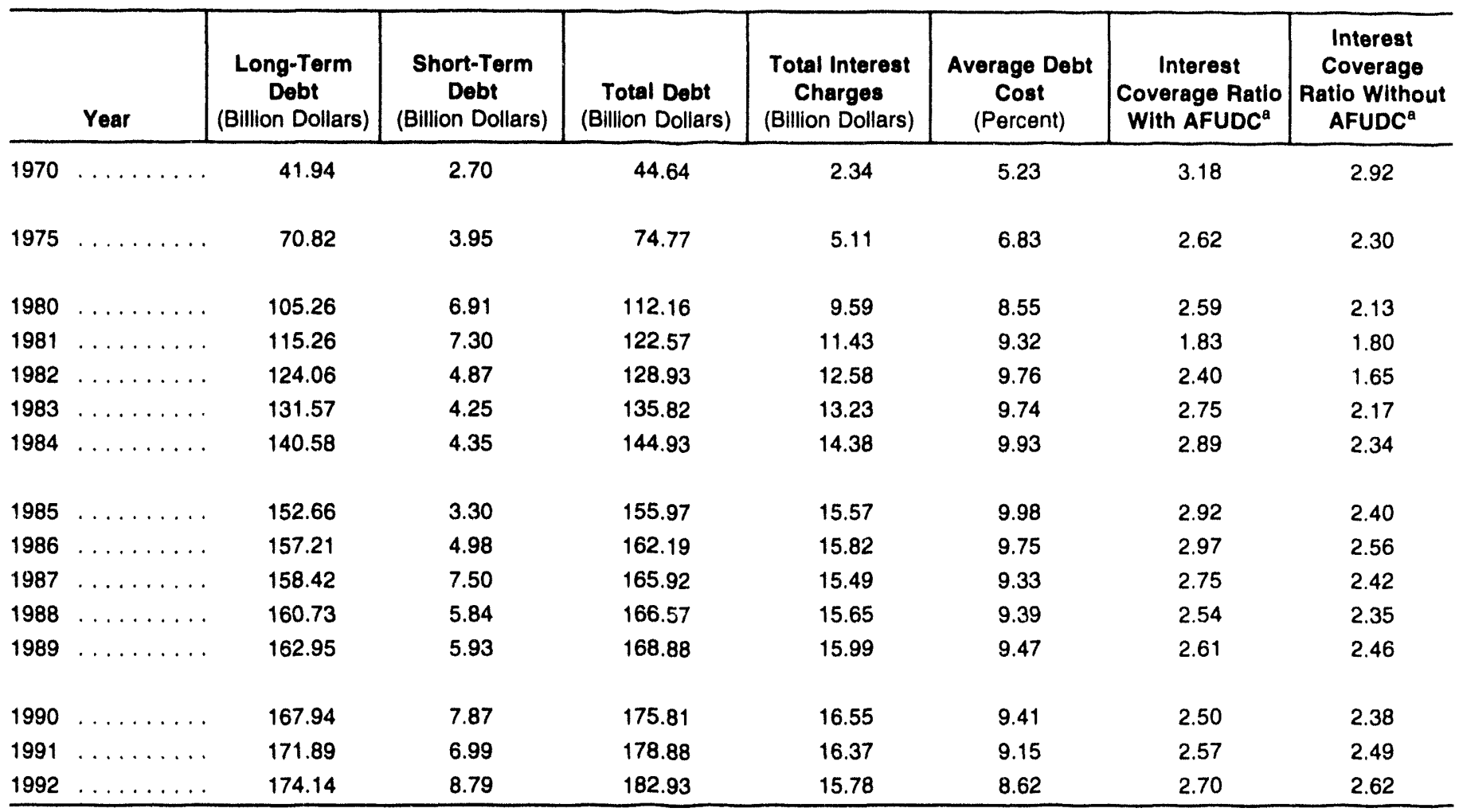

${ }^{a}$ AFUDC is the Allowance for Funds Used During Construction.

Sources: Long-Term Debt, Short-Term Debt, Total Debt, Total Interest Charges, Average Debt Cost-Energy Information Administration, Financial Statistics of Major U.S. Investor-Owned Electric Utilities 1992, DOE/EIA-0437(92)/1 (Washington, DC, December 1993), p. 39, and predecessor publications. Interest Coverage Ratio With AFUDC, Interest Coverage Ratio Without AFUDC: 1970-1982-Energy Information Administration, Financial Analysis of Investor-Owned Electric Utilities, DOE/EIA-0499 (Washington, DC, November 1986), p. 12. 1983-1992Federal Energy Regulatory Commission, FERC Form No. 1, "Annual Report of Major Electric Utilities, Licensees and Others," $1983-1992$.

The disproportionate growth in interest payment charges occurred at a time when utilities were generally facing a profit squeeze. Selling additional debt was not a feasible option and the conventionally maintained capitalization ratios did not change materially during the early 1980s even though efforts were made to sell equity aggressively during this period.

Note that the investment community views pretax earnings as a measure of a firm's capability to meet its interest and other fixed payment obligations. This capability is measured by looking at the number of times that fixed (interest) charges are earned by a firm. This relationship, known to financial analysts as the "interest covcrage ratio," measures the capability between a firm's earnings and its obligations to pay interest on funded debts (including leases) and any sinking fund obligations. As an example, if the earnings are $\$ 30$ and the fixed interest charges are $\$ 10$, the interest coverage ratio is 3 . The interest coverage ratio is calculated using earnings before taxes, with or without AFUDC. An interest coverage ratio of greater than 3 is considered desirable by financial analysts. According to the Securities and Exchange Commission, any utility with an interest-coverage ratio below 2 cannot issue debt.

Rising interest costs and the failure of earnings to increase in some commensurate measure led to a continuing decline in the interest coverage ratios from the late 1970s through the early 1980 s (Table 7). Rating agencies commenced the downgrading of bonds of affected investor-owned utilities. Data for the 1970-1982 period show that downgradings outnumbered upgradings by a ratio of nearly 3 to $1 .^{42}$ The impact of this development was to create additional financial

\footnotetext{
${ }^{42}$ For the period 1970-1982, there were 71 upgradings and 220 downgradings. Based on data from Standard and Poor's, "Industry Surveys: Utilities-Electric," various issues.
} 
Table 8. Capital Structure of U.S. Investor-Owned Utilities, 1970-1992 (Billion Dollars)

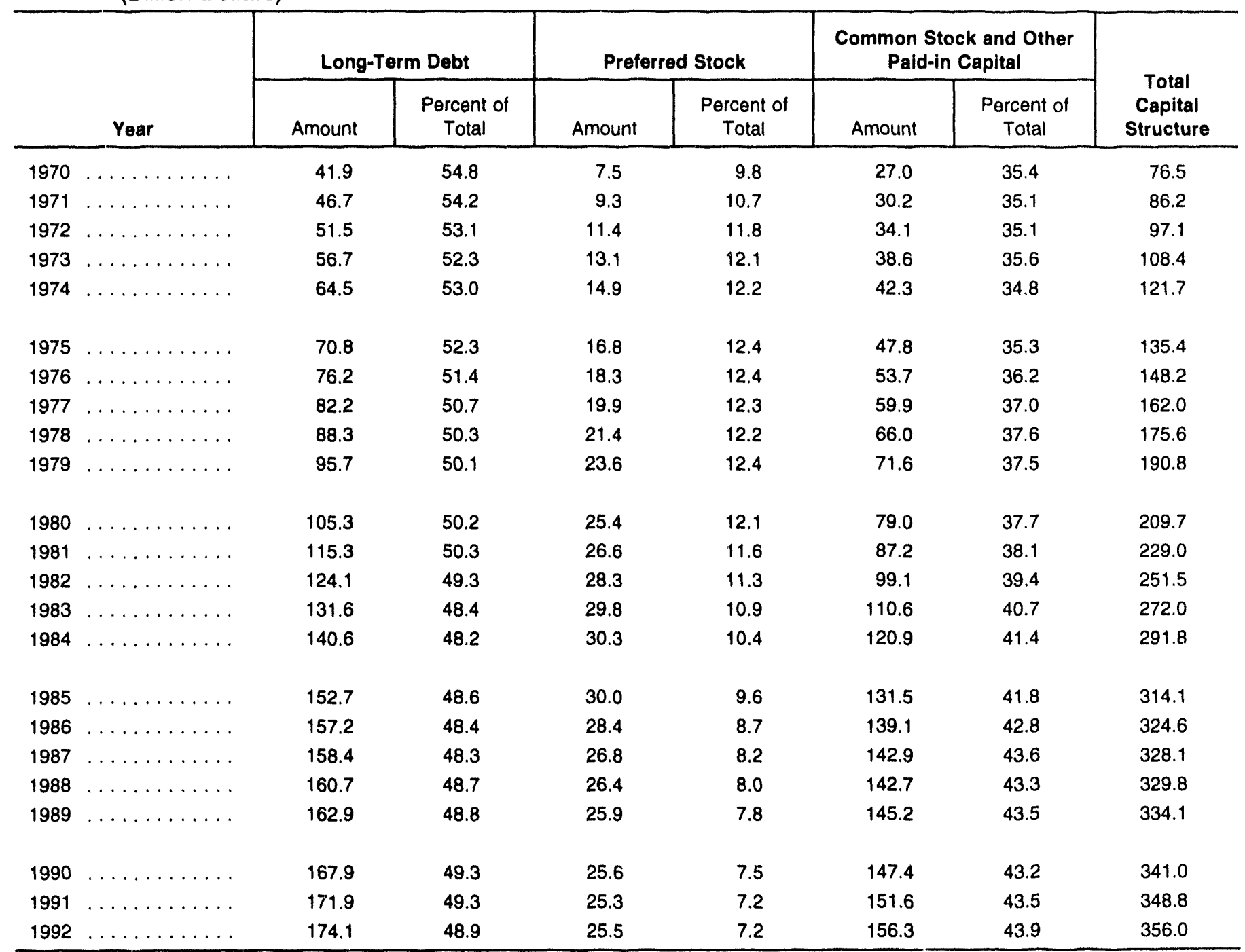

Sources: 1970-1981-Energy Information Administration, Historical Financial Analysis of the Investor-Owned Electric Utility Industry, DOE/EIA-04.33 (Washington, DC, February 1986), p. 32. 1982-1992-Energy Information Administration, Financial Statistics of Major U.S. Investor-Owned Electric Utilities 1992, DOE/EIA-0437(92)/1 (Washington, DC, December 1993), p. 21, and predecessor publications.

difficulties for many utilities whose bonds had been downgraded. Improvements in revenues since the mid1980 s have been instrumental in raising the interest coverage ratios to levels that are more acceptable to the investment analysts. ${ }^{43}$

In 1981, the capitalization ratios (Table 8) were: 38 percent for common stocks, 12 percent for preferred stocks, and slightly over 50 percent for long-term debts. Since then, the share of common stock (and other paid in capital) in capitalization has gradually increased, reaching 44 percent in 1992, with offsetting declines in the shares of preferred stock holdings and long-term debt to 7 percent and 49 percent, respectively. This changing mix, showing an increase in common equity (and a decline in the shares of long-term debt and preferred stock) may be viewed as a sign of improved

\footnotetext{
${ }^{43}$ Bond-rating agencies contend that downgradings during the last 2 to 3 years have also resulted from lowered interest coverage ratios due to the impact of power purchase agreements (PPAs) by a number of investor-owned utilities. Interest coverage ratios shown in Table 7 do not include fixed payment obligations due to PPAs.
} 
financial performance in comparison with investorowned utilities' financial performance in the earlier part of the decade. ${ }^{44}$

In addition, qualitative improvements in income added to the attractiveness of utility stocks in the market, as evidenced by correspondingly progressive improvements in the price-earnings $(\mathrm{P} / \mathrm{E})$ and the market-tobook (M/B) ratios (Tables 9 and 10).$^{45}$ These two ratios are generally used as indicators of investor confidence for any given stock.

A high growth stock will usually have a $\mathrm{P} / \mathrm{E}$ ratio of about 12 or more. The $\mathrm{P} / \mathrm{E}$ ratio of utility stocks averaged about 20 in the mid-1960s, dropped to a low of 6.2 in 1981, and gradually increased to slightly over 12 only in 1987 (Table 9). The book value may be viewed as the accountant's perspective and the market value as the one corresponding with the investor's perspective. The $M / B$ ratio should at least equal 1 , indicating equivalence between the market and book valuations. Since sale of new equity with an $M / B$ ratio below 1 implies a dilution of the existing stockholders' equity, there exists a reluctance to traverse this route. Continuing improvements in the $M / B$ ratio commenced only after 1984, making it attractive for the investorowned utilities to sell common stock (Table 10).

Improvements in the capitalization mix are likely to be pursued aggressively as the investor-owned utilities strive to reinforce the balance sheet strength in an increasingly competitive environment. Part of this stimulus is attributable to the passage of the Energy Policy Act of 1992 which makes it easier for nonutility generators to produce and market power. Recognizing that some loss of market share may be inevitable in the future, the investor-owned utilities may have to confront prices that are determined in the market by interaction of demand and supply rather than by the cost-of-service regulatory approach as in the past. Confronted with this prospect, one way to meet competitive forces is to enlarge the share of equity in capitalization. This move could enable the investorowned utilities to improve the quality of their assets,
Table 9. Utility Stock and Standard and Poor's $\mathbf{5 0 0}$ Price-Earnings (P/E) Ratios, 1970-1992

\begin{tabular}{|c|c|c|c|}
\hline & Year & $\begin{array}{l}\text { Utility Stock } \\
\text { P/E Ratios }\end{array}$ & $\begin{array}{l}\text { S\&P } 500 \\
\text { Composite } \\
\text { P/E Ratios }\end{array}$ \\
\hline 1970 & $\ldots \ldots \ldots \ldots \ldots$ & 11.93 & 15.07 \\
\hline 1971 & $\ldots \ldots \ldots \ldots \ldots$ & 12.86 & 18.63 \\
\hline 1972 & $\ldots \ldots \ldots \ldots \ldots$ & 11.37 & 18.92 \\
\hline 1973 & $\ldots \ldots \ldots \ldots \ldots$ & 10.02 & 15.95 \\
\hline 1974 & $\ldots \ldots \ldots \ldots \ldots$ & 7.87 & 9.91 \\
\hline 1975 & $\ldots \ldots \ldots \ldots \ldots$ & 7.38 & 10.24 \\
\hline 1976 & $\ldots \ldots \ldots \ldots \ldots$ & 8.39 & 12.19 \\
\hline 1977 & $\ldots \ldots \ldots \ldots \ldots$ & 8.69 & 9.75 \\
\hline 1978 & $\ldots \ldots \ldots \ldots \ldots$ & 8.12 & 8.72 \\
\hline 1979 & $\ldots \ldots \ldots \ldots \ldots$ & 7.38 & 7.91 \\
\hline 1980 & $\ldots \ldots \ldots$ & 6.52 & 8.00 \\
\hline 1981 & $\ldots \ldots \ldots \ldots \ldots$ & 6.17 & 8.63 \\
\hline 1982 & $\ldots \ldots \ldots \ldots \ldots$ & 6.39 & 8.17 \\
\hline 1983 & $\ldots \ldots \ldots \ldots \ldots$ & 6.79 & 12.59 \\
\hline 1984 & $\ldots \ldots \ldots \ldots \ldots$ & 6.20 & 10.75 \\
\hline 1985 & $\ldots \ldots$ & 7.34 & 11.52 \\
\hline 1986 & $\ldots \ldots \ldots \ldots \ldots$ & 8.95 & 15.99 \\
\hline 1987 & $\ldots \ldots \ldots \ldots \ldots$ & 12.08 & 19.21 \\
\hline 1988 & $\ldots \ldots \ldots \ldots \ldots$ & 10.42 & 13.99 \\
\hline 1989 & $\ldots \ldots \ldots \ldots \ldots$ & 10.93 & 13.34 \\
\hline 1990 & $\ldots \ldots \ldots$ & 13.06 & 15.15 \\
\hline 1991 & $\ldots \ldots \ldots \ldots \ldots$ & 13.91 & 18.65 \\
\hline 1992 & $\ldots \ldots \ldots \ldots \ldots$ & 13.27 & 14.52 \\
\hline
\end{tabular}

Sources: Standard and Poor's, Industry Surveys: UtilitiesElectric (January 14, 1993, and earlier issues). Standard and Poor's Compustat Services, Inc.

making it feasible for them to absorb potential writeoffs in an effort to remain competitive.

\section{Net Income Levels}

As indicated earlier, despite the improvements in the quality of earnings, net income levels for the investorowned utilities have declined in real and absolute terms

\footnotetext{
${ }^{41}$ Bond-rating agencies are likely to debate this conclusion if the fixed payment obligations of the power purchase agreements are also added to derive the interest coverage ratios.

${ }^{45}$ Financial analysts generally contend that asset prices reflect all available and relevant information. The behavior of the participants in their evaluation of a given asset (leading to changes in its market price) provides valuable insights concerning its possible future. The price-earnings ratios and the market-to-book ratios furnish some indication of how the market perceives a firm's growth and its potential for profitability. The $\mathrm{P} / \mathrm{E}$ ratio is calculated as the market price per share divided by the earnings per share. The $\mathrm{M} / \mathrm{B}$ ratio is calculated as the market price per share divided by the book value (assets minus liabilities) per share.
} 
Table 10. Market Price and Book Value of Utility Common Stocks, 1970-1992

\begin{tabular}{|c|c|c|c|c|}
\hline & Year & $\begin{array}{l}\text { Market Price } \\
\text { (Dollars per } \\
\text { Share) }\end{array}$ & $\begin{array}{c}\text { Book Value } \\
\text { (Dollars per } \\
\text { Share) }\end{array}$ & $\begin{array}{l}\text { Ratio of Market } \\
\text { Price to Book Value } \\
\text { (Percent) }\end{array}$ \\
\hline 1970 & $\ldots \ldots \ldots \ldots \ldots \ldots \ldots$ & 79.06 & 64.09 & 1.23 \\
\hline 1971 & $\ldots \ldots \ldots \ldots \ldots \ldots \ldots \ldots$ & 84.16 & 66.37 & 1.27 \\
\hline 1972 & $\ldots \ldots \ldots \ldots \ldots \ldots \ldots$ & 80.20 & 70.41 & 1.14 \\
\hline 1973 & $\ldots \ldots \ldots \ldots \ldots \ldots \ldots \ldots$ & 71.21 & 71.67 & 0.99 \\
\hline 1974 & $\ldots \ldots \ldots \ldots \ldots \ldots \ldots$ & 48.26 & 73.23 & 0.66 \\
\hline 1975 & $\ldots \ldots \ldots \ldots \ldots$ & 51.25 & 75.80 & 0.68 \\
\hline 1976 & $\ldots \ldots \ldots \ldots \ldots \ldots \ldots$ & 60.10 & 76.94 & 0.78 \\
\hline 1977 & $\ldots \ldots \ldots \ldots \ldots$ & 67.55 & 78.82 & 0.86 \\
\hline 1978 & $\ldots \ldots \ldots \ldots \ldots \ldots \ldots$ & 63.54 & 80.11 & 0.79 \\
\hline 1979 & $\ldots \ldots \ldots \ldots \ldots \ldots \ldots \ldots$ & 60.28 & 81.62 & 0.74 \\
\hline 1980 & $\ldots \ldots \ldots \ldots \ldots \ldots \ldots \ldots$ & 54.80 & 83.82 & 0.65 \\
\hline 1981 & $\ldots \ldots \ldots \ldots \ldots \ldots \ldots$ & 55.41 & 81.90 & 0.68 \\
\hline 1982 & $\ldots \ldots \ldots \ldots \ldots \ldots \ldots \ldots$ & 63.56 & 82.77 & 0.77 \\
\hline 1983 & $\ldots \ldots \ldots \ldots \ldots \ldots \ldots \ldots$ & 74.04 & 82.90 & 0.89 \\
\hline 1984 & $\ldots \ldots \ldots \ldots \ldots \ldots \ldots \ldots$ & 71.16 & 85.08 & 0.84 \\
\hline 1985 & $\ldots$ & 87.24 & 87.76 & 0.99 \\
\hline 1986 & $\ldots \ldots \ldots \ldots \ldots \ldots \ldots$ & 111.11 & 90.35 & 1.23 \\
\hline 1987 & $\ldots \ldots \ldots \ldots \ldots \ldots \ldots$ & 105.90 & 90.12 & 1.18 \\
\hline 1988 & $\ldots \ldots \ldots \ldots \ldots \ldots \ldots \ldots$ & 97.99 & 88.04 & 1.11 \\
\hline 1989 & $\ldots \ldots \ldots \ldots \ldots \ldots \ldots \ldots$ & 110.45 & 89.41 & 1.24 \\
\hline 1990 & & 112.61 & 84.45 & 1.33 \\
\hline 1991 & . & 126.97 & 91.07 & 1.39 \\
\hline 1992 & $\ldots \ldots \ldots \ldots \ldots \ldots$ & 137.07 & 93.68 & 1.46 \\
\hline
\end{tabular}

a Based on an average of end-of-month weighted averages for the year as a whole.

bEnd-of-year weighted average value, exclusive of reserves for deferred Federal income taxes arising from liberalized depreciation and the investment credit.

Source: Moody's Investor Services, Inc., Moody's Public Utility Manual, 1993 (New York, 1993), pp. a12 and a15.

since $1986{ }^{46}$ Nominal prices, sales, and operating expenses are the variables in the determination of net incomes. Prices during 1986-1992 remained virtually flat, with an average annual increase of 1.0 percent (Figure 3). Sales during this period increased from 2,369 billion kilowatthours in 1986 to 2,763 billion kilowatt- hours in 1992 or an average annual rate of 2.6 percent (Table 2). Electric operating expenses (made up of operation and maintenance expenses, depreciation and amortization, Federal and other taxes, provisions for deferred taxes, investment tax credit adjustments, and gains/losses from disposition of utility plants)

\footnotetext{
${ }^{46}$ It may be noted that the accounting derivation of net income (before taxes and extraordinary items) follows a pattern that reflects the classification of expenses in ratemaking procedures. Electric utility operating income (subject to regulation) is obtained by deducting its total operating expenses from total operating revenues. Other income and deductions (not usually taken into account in ratemaking proceedings) and interest expense (used in determining the rate of return) are then taken into account in computing the operating income. Operating expenses are usually referred to as "above-the-line" expensts because they are allowable in ratemaking and are crucial in the determination of electric utility income. Interest expenses and other income deductions are, therefore, considered as "below-the-line" because they are applied after computation of operating income. For a detailed breakdown of the classification scheme, see Energy Information Administration, Financial Statistics of Major U.S. Investor-Owned Utilities 1992, DOE/EIA-0437(92)/1 (Washington, DC, January 1994), Table 6, pp. 16-18.
} 
increased at 4.0 percent annually, from $\$ 110.2$ billion in 1986 to $\$ 139.0$ billion in 1992 . These differential growth rates have in the main constrained contributions to the growth of net income levels.

Note that the stagnant growth in income levels have their counterpart in net income per share of common stock. Net dollar income per share of common stock which peaked at $\$ 3.43$ per share in 1986 declined to $\$ 2.61$ in 1992 (Table 11). ${ }^{47}$

It is interesting to note that the investor-owned utilities were successfully able to market the sale of common stock during the above period. A favorable regulatory climate, the state of the economy and declining interest rates were the primary factors that supported this effort. Sustaining this trend depends on a continuation of these trends. Problems could arise, however, if any of these variables change adversely in the future.

\section{Construction Expenditures}

Industry's investment activities, i.e, expenditures on new plant construction and equipment continue to decline. From a high of $\$ 31.2$ billion in 1982 , the spending in 1992 totaled $\$ 27.3$ billion reflecting a decline in real and absolute terms. Despite additions to

Table 11. Disposition of Net Income per Share, 1970-1992

(Billion Dollars)

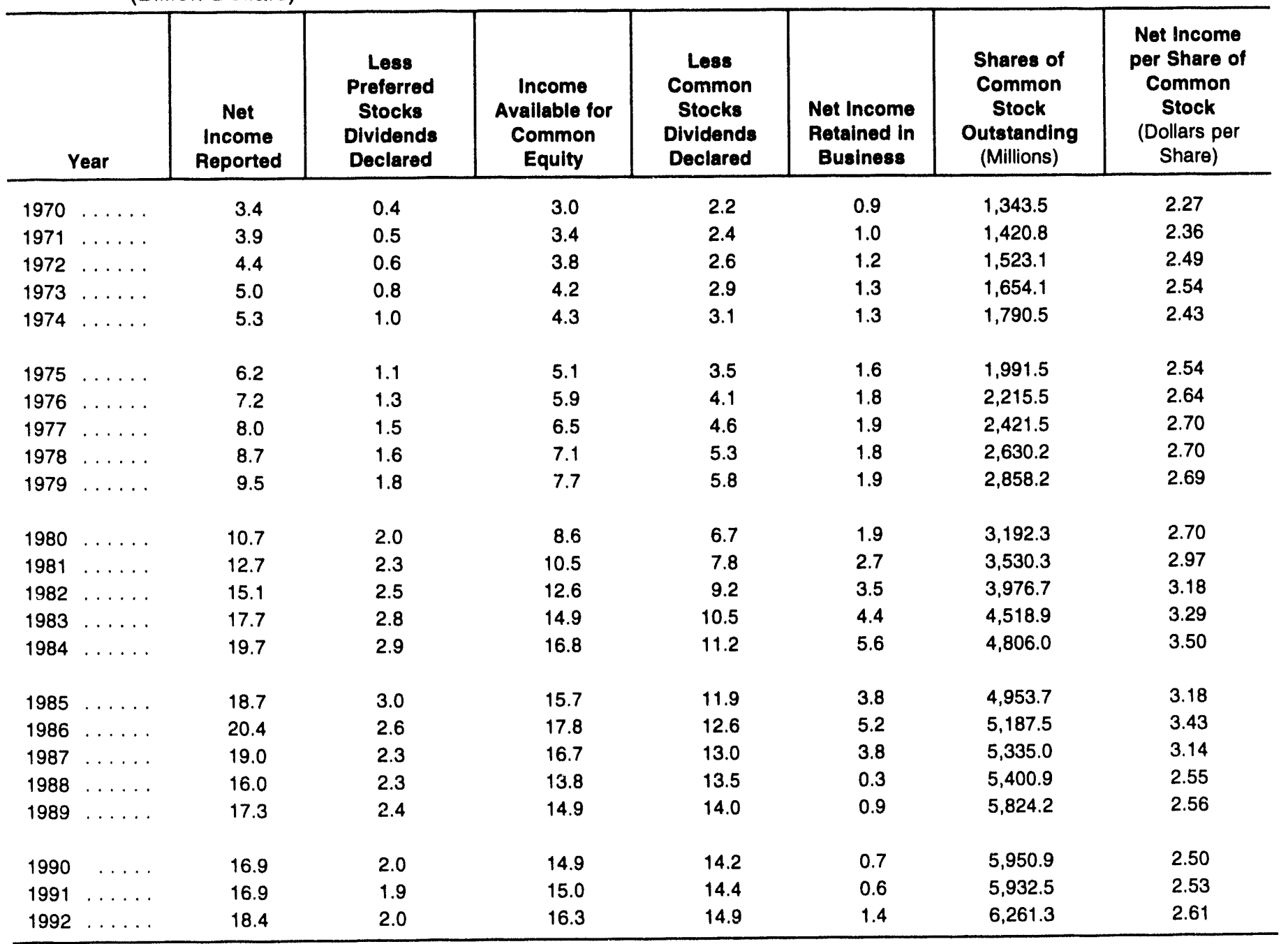

Source: Energy Information Administration. Financial Statistics of Major U.S. Investor-Owned Electric Utilities 1992, DOE/EIA-0437(92)/1 (Washington, DC, Decernber 1993), p. 40, and predecessor publications.

${ }^{47}$ Another contributory factor is the increase in the number of shares of common stock. 
capacity that will be needed between now and the year 2010, levels of construction expenditures may continue to decline in the foreseeable future. ${ }^{48}$

Investor-owned utilities, in the past, had a vested interest in enlarging the size of the asset base within the traditional cost-plus regulatory approach. With the entry of nonutility power generators and exempt wholesale power producers as envisaged by the EPACT, electricity rates in the future are more likely to be determined by the market (i.e., by conditions of demand and supply) rather than by sunk costs as in the past. Given this prospect, the certainty of full cost recovery normally assured within the traditional ratemaking procedures may no longer be feasible. It is not surprising, therefore, that the investor-owned utilities have currently planned for only 16.4 gigawatts of new plant construction. Planned nonutility construction is stated to be about 23.4 gigawatts. The remaining capacity needs will be filled in the competitive marketplace, with repowering of existing fossil-fuel plants playing an important role in filling projected capacity needs. ${ }^{49}$

In view of the foregoing, a significant increase in the levels of construction expenditures to aggressively fund large-scale generating projects by the investor-owned utilities in the near term is ruled out. Besides planning for modest capacity increases, currently planned expenditures may also include demand-side management initiatives, expansion of transmission and distribution systems, outlays for meeting the Clean Air Act require- ments, addition of peaking units, decommissioning, acquisitions, and others.

The self-imposed constraints on undertaking new construction activity are occurring at a time when the investor-owned utilities have the sustained capability to finance over 80 percent of the capital expenditures from internally generated funds implying that only 20 percent of these expenditures need to be obtained from external sources, i.e., by sale of debts or equity. ${ }^{50}$ In comparison, nearly 70 percent of the construction expenditures had to be sourced from external sources during the early 1970 s. $^{51}$

\section{Conclusions}

Overall, the investor-owned segment of the electric utility industry is on a stronger financial base than it was a decade ago. However, the utilities are also faced with the prospect of having to confront competitive forces in the production and sale of electric power in the future. One way in which the industry can meet this challenge is to retain its financial flexibility by not assuming fresh liabilities implicit in the construction of new power plants. Mergers and acquisition are the other options that may become attractive as the industry attempts to restructure to remain competitive. Nonetheless, the investor-owned utilities will encounter some erosion in their activities in the future. The vertically integrated electric entity, and the associated industry structure, may undergo fundamental structural changes.

\footnotetext{
${ }^{48}$ Comparative estimates of new capacity additions between 1993 and 2010 vary among various forecasting groups. Based on recent projections of electricity demand growth in the range of 1.0 to 1.5 percent a year between 1990 and 2010, the EIA projects new generating capacity (including offsets for retirements) to be 172 gigawatts in the Reference Case. Similar projections available from DRI/McGraw-Hill indicate that over 210 gigawatts of new capacity will be required to support an annual demand growth averaging 2.0 percent for the period ending in 2010. Forecasts of capacity requirements from the Edison Electric Institute are still higher. See Energy Information Administration, Annual Energy Outlook 1994, DOE/EIA-0383(94) (Washington, DC, January 1994), pp. $22-29$.

${ }^{40}$ Larry Makovich and Gregg Smally, "Electricity Outlook," DRI/McGraw Hill Energy Review, Fall-Winter 1993-94, pp. 43-56.

${ }^{50}$ These percentages can vary depending on what is included or excluded in computing internally generated funds. More recently, it has been pointed out that the investor-owned utilities may be able to finance over 90 percent of the construction expenditures from internal sources of funds during the 1993-1997 period. See Kathleen A. Lally, Electric Utilities-Monthly Update (New York, NY: Salomon Brothers, October 1993), pp. 1-3.

${ }^{51}$ The contribution of internally generated funds has been computed by using data in Table 10 entitled "Composite Statement of Cash Flows for Major U.S. Investor-Owned Electric Utilities, 1988-1992" in Energy Information Administration, Financial Statistics of Major U.S. Investor-Owned Electric Utilities 1992, DOE/EIA-0437(92)/1 (Washington, DC, December 1993), and predecessor publications.
} 


\section{Financial Impacts of Nonutility Power Purchases On Utility Cost of Capital}

\section{Background}

The basis for the concern about how long-term contracts for nonutility power purchases affect a utility's cost of capital lies in the manner in which nonutility power projects are financed. The vast majority of these nonutility generating facilities use a structure known as "project financing." This structure relies upon long-term purchase contracts with utilities that provide an assured market and price for electricity, subject to performance requirements. The long-term contract, in particular the capacity payments that they typically entail, is perceived by bond-rating agencies to be a long-term liability to the utility.

Bond-rating agencies treat a fixed payment liability associated with a power purchase contract analogously with a utility's long-term debt. ${ }^{52}$ Where power purchases by a utility become significant, its imputed fixed payment obligations increase correspondingly. Principal bond-rating agencies aggregate a utility's existing debt with some portion of the fixed payment obligations to compute its total long-term debt liability. ${ }^{53}$ This process has the potential of adversely changing a utility's capitalization structure, in which case the possibility of its bonds being downgraded becomes real. Where a bond downgrading does take place, the affected utility would be expected to pay more than before in acquiring new capital in the market.

This chapter analyzes the financial impacts of nonutility power purchases on the utility cost of capital by using two different methodological approaches. The first is a comparative financial assessment of two groups of investor-owned utilities with and without significant power purchases from nonutility generators, using fi- nancial data from the Federal Energy Regulatory Commission (FERC) Form 1. The second analyzes the same problem from the perspective of the equity market and presents the results of an empirical study.

\section{Comparative Financial Assessment of Two Investor-Owned Utility Groups with and without Nonutility Power Purchase Contracts}

\section{Data Sources}

The first analysis uses the following methodology. First, a group of investor-owned utilities are identified that purchase significant levels of power/capacity from nonutility generators (NUGs). ${ }^{54}$ For the period from 1986 through 1992, their financial data, as available from FERC Form 1, are abstracted and aggregated. Next, another group with little or no power purchases is selected, and similar financial statistics for this group are collated from FERC Form 1 submissions.

Thus, there are two data sets: one consisting of investor-owned utilities with significant power purchase commitments from nonutility generators and the other with no such significant commitments. The group with significant power purchases is called "SIGNUGs" and the other group is called "NONUGs." The two financial data sets are compared to evaluate whether there is an emerging trend in key financial and performance ratios that indicates differences between the two groups that can be attributed, in part, to purchased power contracts and in particular to purchases from

\footnotetext{
${ }^{52}$ Chapter 4 presents a full discussion of this subject.

${ }^{53}$ For a description of the methodology adopted by the bond-rating agencies in computing fixed payment obligations, refer to the discussion in Chapter 4.

${ }^{54}$ Data as available with the Energy Information Administration, on Form EIA-861, "Annual Electric Utility Report," Form EIA-867, "Annual Nonutility Power Producer Report," Form EIA-767, "Steam-Electric Plant Operation and Design Report," and Federal Energy Regulatory Commission FERC Form 1, "Annual Report of Major Electric Utilities, Licensees, and Others," were used to identify investorowned utilities purchasing power/capacity from NUGs (that include qualified facilities, independent power producers, small power producers or exempt wholesale generators) at levels close to or exceeding 9 percent.
} 
nonutility generators. The emphasis is to closely evaluate the quality of earnings of the two sets of investorowned utilities. Additional tests are performed to make a comparative evaluation of the two data sets by applying principles of standard financial analysis. Finally, conclusions of this analysis together with appropriate caveats are stated.

In addition to data from FERC Form 1, annual reports (together with $10-\mathrm{K}$ submissions to the Securities and Exchange Commission) from the respective investorowned utilities were used to secure supplementary information and ensure consistency. ${ }^{55} \mathrm{~A}$ list of the investor-owned utilities selected in each group is provided in Appendix B.

\section{Selection Process}

Only major investor-owned utilities, as represented by their FERC filings, were considered ${ }^{56}$ Data on purchased power from Form EIA-867, Form EIA-861, Form EIA-767 and FERC Form 1 for 1991 were used to identify investor-owned utilities with power purchases (from nonutility generators) of approximately 9 percent or more of capacity/total energy sources. Investorowned utilities with electric revenues in excess of $\$ 850$ million in 1991 and located within the contiguous 48 States were selected for inclusion in the category SIGNUGs. ${ }^{57}$

To match the SIGNUGs group, investor-owned utilities in the NONUGs group were identified on the basis of their comparability in operating revenues. Approximation of regional characteristics, to the extent possible, was another measure used in matching NONUGs with SIGNUGs. Customer bases were also considered. These considerations were used by comparing data for the year 1991 only.
Note that precise equivalence between data sets of the two groups is difficult to attain. However, the two groups presented in the sample have nearly the same revenue and net income levels (Tables 12 and 13). For 1991, the combined sample represents 50.7 percent of total electric revenues, 46.0 percent of total end-use electricity sales, and 49.3 percent of net electric utility plant. ${ }^{58}$ For purposes of making broad generalizations based on a ratio analysis of aggregated financial statistics, this approach should be considered reasonably valid.

\section{Comparative Financial Analysis}

\section{Capitalization}

Capitalization, as discussed in the previous chapter, consists of long-term debt, preferred stock, and common stock. Actual and expected returns on these categories of financial instruments vary depending on considerations of demand and supply, market conditions, and utility-specific financial parameters. Rates of return on the first two categories of instruments are fixed and pre-specified, as opposed to common stock, which carries no such stipulation. Common stock holders assume risks higher than those in the first two categories and therefore usually receive a rate of return that is higher than either the bond or the preferred stock. However, if there is no residual income after payments to bond-holders and preferred stockholders in a given time period, holders of common stock will receive no dividends.

While current accounting principles require disclosure of power purchase commitments, the associated fixed obligations resulting from power purchases are not included as debt obligation in the utilities' financial statements. ${ }^{59}$ This lack of information makes it difficult to compute levels of debt-equivalent liability borne by

\footnotetext{
${ }^{55}$ The Securities Exchange Act of 1934 requires that all companies whose stocks are listed on a national exchange file an annual report on Form 10-K with the Securities and Exchange Commission. Information concerning a company's business, its properties, legal and/or regulatory problems, financial operations and other related matters are generally included in the 10-K submissions.

${ }^{56}$ For purposes of FERC Form 1 data submission requirements, major utilities are defined as: utilities that have had, in the past 3 consecutive years, sales or transmission services that exceeded one or more of the following: 1 million megawatthours of total annual sales; 100 megawatthours of annual sales for resale; 500 megawatthours of annual power exchanges delivered; 500 megawatthours of wheeling for others (deliveries plus losses). Source: Energy Information Administration, Financial Statistics of Selected Electric Utilities 1985, DOE/EIA-0437(85) (Washington, DC, January 1987), p. 2.

${ }^{57}$ Only one utility was not included in this group: the Texas Utilities Electric Company due to difficulties associated in finding an appropriate match.

${ }^{58}$ See Energy Information Administration, Financial Statistics of Major U.S. Investor-Owned Electric Utilities 1991, DOE/EIA-0437(91)/1 (Washington, DC, January 1993).

${ }^{59}$ Note that "off-balance-sheet" obligations represented by power purchases are not included in the financial statements. These are, however, disclosed in the notes to the financial statement but lack sufficient detail to undertake a meaningful analysis.
} 
Table 12. Financial and Other Statistics of a Selected Group of Investor-Owned Utilities with Significant Power Purchases from Nonutility Generators, 1986-1992 (Billion Dollars)

\begin{tabular}{|c|c|c|c|c|c|c|c|}
\hline Item & 1986 & 1987 & 1988 & 1989 & 1990 & 1991 & 1992 \\
\hline \multicolumn{8}{|l|}{ Income Statement } \\
\hline Electric Operating Revenues & 32.3 & 32.4 & 34.0 & 36.6 & 39.5 & 42.2 & 43.9 \\
\hline Net Electric Operating Income & 6.1 & 6.0 & 6.6 & 6.7 & 7.6 & 7.0 & 7.0 \\
\hline Total Utility Operating Revenues & 37.0 & 36.7 & 38.6 & 41.2 & 44.0 & 46.5 & 48.1 \\
\hline Net Utility Operating Income & 6.6 & 6.4 & 7.0 & 7.1 & 7.4 & 7.4 & 7.5 \\
\hline Income Before Extraordinary Items $\ldots \ldots \ldots$ & 4.7 & 4.1 & 3.3 & 4.4 & 3.8 & 4.0 & 4.2 \\
\hline \multicolumn{8}{|l|}{ Dividends } \\
\hline Preferred & 0.7 & 0.5 & 0.5 & 0.5 & 0.5 & 0.4 & 0.4 \\
\hline Common $\ldots \ldots \ldots \ldots$ & 2.7 & 2.7 & 3.0 & 3.0 & 2.9 & 3.0 & 3.2 \\
\hline \multicolumn{8}{|l|}{ Balance Sheet } \\
\hline Net Electric Utility Plant . . . . . . . . . . & 70.0 & 71.4 & 72.7 & 74.4 & 76.0 & 77.3 & 77.8 \\
\hline Total All Utility Plant $\ldots \ldots \ldots \ldots \ldots \ldots$ & 100.4 & 105.3 & 109.5 & 114.2 & 119.2 & 124.4 & 128.9 \\
\hline Net All Utility Plant $\ldots \ldots \ldots \ldots \ldots \ldots$ & 76.0 & 78.2 & 79.4 & 808 & 82.6 & 84.1 & 85.3 \\
\hline Total Other Property and Investments ..... & 2.0 & 3.7 & 3.9 & 4.2 & 4.3 & 3.9 & 4.7 \\
\hline Tctal Assets $\ldots \ldots \ldots \ldots \ldots \ldots \ldots \ldots$ & 96.6 & 101.8 & 103.4 & 104.2 & 106.6 & 107.5 & 112.8 \\
\hline Total Capitalization . . . . . . . . . . . . . . & 71.8 & 72.4 & 72.7 & 74.9 & 75.6 & 76.2 & 77.5 \\
\hline Total Long-Term Debt . . . . . . . . . . . . . & 34.7 & 35.4 & 36.8 & 37.6 & 37.6 & 37.7 & 37.6 \\
\hline Total Preferred Debt/Stock . . . . . . . . . . & 6.2 & 6.1 & 5.9 & 5.9 & 5.9 & 5.6 & 5.8 \\
\hline Common Equity $\ldots \ldots \ldots \ldots \ldots \ldots$ & 30.9 & 30.9 & 30.1 & 31.4 & 32.1 & 32.9 & 34.1 \\
\hline Total Liabilities \& Equity $\ldots \ldots \ldots \ldots \ldots$ & 96.6 & 101.8 & 103.4 & 104.2 & 106.6 & 107.5 & 112.8 \\
\hline \multicolumn{8}{|l|}{ Cash Flow Statement } \\
\hline Net Cash From Operations & NA & NA & 9.5 & 9.3 & 9.0 & 9.9 & 10.0 \\
\hline Net Cash from Investing $\ldots \ldots \ldots \ldots$ & NA & NA & -6.8 & -5.9 & -6.5 & -5.7 & -7.0 \\
\hline Net Cash Financing $\ldots \ldots \ldots \ldots \ldots$ & NA & NA & -2.5 & -3.5 & -2.1 & -4.4 & -2.9 \\
\hline Capital Expenditures on Plant ...... & 7.0 & 6.2 & 6.5 & 5.8 & 6.1 & 6.2 & 6.5 \\
\hline Payment on Debt $\ldots \ldots \ldots \ldots \ldots \ldots$ & 6.6 & 3.5 & 3.3 & 3.0 & 2.0 & 3.2 & 7.5 \\
\hline Resale Revenue $\ldots \ldots \ldots \ldots \ldots \ldots$ & 2.2 & 2.3 & 2.1 & 2.3 & 2.8 & 3.3 & 3.5 \\
\hline$\ldots \ldots \ldots \ldots \ldots \ldots$ & 4.2 & 4.4 & 5.4 & 6.4 & 8.4 & 9.6 & 11.2 \\
\hline \multicolumn{8}{|l|}{ Energy Accounts (billion kilowatthours) } \\
\hline Total Sales to Ultimate Consumers & 410.2 & 427.1 & 446.5 & 455.8 & 463.4 & 466.6 & 470.1 \\
\hline Total Generation and Received . . . . . . . . . & 492.1 & 514.5 & 530.9 & 540.0 & 553.5 & 569.7 & 589.5 \\
\hline Total Purchases $\ldots \ldots \ldots \ldots \ldots \ldots$ & 117.1 & 111.0 & 129.1 & 142.2 & 159.5 & 189.9 & 201.6 \\
\hline Purchases-Nonutility $\ldots \ldots \ldots \ldots \ldots \ldots$ & 24.5 & 27.8 & 40.7 & 55.4 & 78.0 & 95.1 & 111.9 \\
\hline \multicolumn{8}{|l|}{ Nonutility Purchases/Total Sales to } \\
\hline Ultimate Consumers (percent) . . . & 6.0 & 6.5 & 9.1 & 12.1 & 16.8 & 20.4 & 23.8 \\
\hline
\end{tabular}

Note: Sum of components may not equal total due to independent rounding.

$\because=$ value less than 0.05 .

Source: Federal Energy Regulatory Commission, FERC Form 1, "Annual Report of Major Electric Utilities, Licensees, and Others" for 1992 and previous years. 
Table 13. Financial and Other Statistics of a Selected Group of Investor-Owned Utilities without Significant Power Purchases from Nonutility Generators, 1986-1992 (Billion Dollars)

\begin{tabular}{|c|c|c|c|c|c|c|c|}
\hline Item & 1986 & 1987 & 1988 & 1989 & 1990 & 1991 & 1992 \\
\hline Electric Operating Revenues $\ldots \ldots \ldots \ldots$ & 36.2 & 36.9 & 37.8 & 39.0 & 39.8 & 42.3 & 42.2 \\
\hline Total Utility Operating Revenues $\ldots \ldots \ldots$ & 38.8 & 39.2 & 40.1 & 41.6 & 42.3 & 44.8 & 45.0 \\
\hline Net Utility Operating Income $\ldots \ldots \ldots \ldots$ & 7.3 & 7.7 & 8.0 & 8.6 & 8.2 & 9.0 & 8.7 \\
\hline Income Before Extraordinary Items $\ldots \ldots \ldots$ & 5.8 & 5.5 & 4.3 & 4.5 & 4.4 & 4.9 & 5.2 \\
\hline \multicolumn{8}{|l|}{ Dividends } \\
\hline Preferred & 0.7 & 0.6 & 0.6 & 0.5 & 0.5 & 0.5 & 0.4 \\
\hline Common & 3.1 & 3.3 & 3.7 & 3.8 & 4.1 & 3.8 & 4.0 \\
\hline \multicolumn{8}{|l|}{ Balance Sheet } \\
\hline Net Electric Utility Plant . . . . . . . . . . & 91.0 & 93.1 & 93.0 & 94.3 & 94.8 & 95.2 & 96.1 \\
\hline Total All Utility Plant $\ldots \ldots \ldots \ldots \ldots \ldots$ & 123.6 & 129.8 & 133.2 & 138.2 & 142.3 & 146.2 & 151.0 \\
\hline Net All Utility Plant $\ldots \ldots \ldots \ldots \ldots \ldots$ & 96.3 & 99.3 & 99.1 & 100.5 & 100.9 & 101.2 & 102.6 \\
\hline Total Other Property and Investments & 1.8 & 1.6 & 1.3 & 1.7 & 2.5 & 3.1 & 3.2 \\
\hline Total Assets & 113.8 & 119.0 & 119.1 & 121.3 & 123.2 & 124.4 & 126.6 \\
\hline Total Capitalization & 86.2 & 87.9 & 87.3 & 87.5 & 88.9 & 89.6 & 90.3 \\
\hline Total Long-Term Debt & 41.7 & 42.6 & 42.3 & 42.4 & 44.4 & 44.3 & 43.8 \\
\hline Total Preferred Debt/Stock & 7.3 & 6.8 & 6.6 & 6.2 & 6.0 & 5.9 & 5.8 \\
\hline Common Equity $\ldots \ldots \ldots \ldots \ldots \ldots \ldots$ & 37.2 & 38.5 & 38.4 & 38.9 & 38.6 & 39.4 & 40.7 \\
\hline Total Liabilities $\ldots \ldots \ldots \ldots \ldots \ldots \ldots \ldots$ & 113.8 & 119.0 & 119.1 & 121.3 & 123.2 & 124.4 & 126.6 \\
\hline \multicolumn{8}{|l|}{ Cash Flow Statement } \\
\hline Resale Revenue $\ldots \ldots \ldots \ldots \ldots \ldots \ldots$ & 4.1 & 4.1 & 3.4 & 3.9 & 3.9 & 4.4 & 4.4 \\
\hline Purchased Power $\ldots \ldots \ldots \ldots \ldots \ldots \ldots$ & 3.4 & 3.6 & 3.5 & 3.3 & 3.4 & 4.3 & 4.4 \\
\hline \multicolumn{8}{|l|}{ Energy Accounts (billion kilowatthours) } \\
\hline Total Sales To Ultimate Consumers . . . . . . . & 432.8 & 451.8 & 470.3 & 478.3 & 487.5 & 499.2 & 496.1 \\
\hline Total Generation and Feceived . . . . . . . . . & 595.1 & 579.1 & 597.6 & 605.3 & 610.9 & 657.8 & 649.8 \\
\hline Total Purchases $\ldots \ldots \ldots \ldots \ldots \ldots \ldots$ & 64.5 & 69.7 & 72.2 & 70.9 & 71.8 & 111.4 & 115.2 \\
\hline Purchases-Nonutility $\ldots \ldots \ldots \ldots$ & 2.3 & 2.8 & 3.9 & 4.1 & 4.5 & 7.2 & 11.2 \\
\hline \multicolumn{8}{|l|}{ Nonutility Purchases/Total Sales to } \\
\hline Ultimate Consumers (percent) $\ldots \ldots \ldots \ldots$ & 0.5 & 0.6 & 0.8 & 0.9 & 0.9 & 1.4 & 2.3 \\
\hline
\end{tabular}

Note: Sum of components may not equal total due to independent rounding.

Source: Foderal Energy Regulatory Commission, FERC Form 1, "Annual Report of Major Electric Utilities, Licensees, and Others" for 1992 and previous years. 
each SIGNUG. ${ }^{60}$ Assuming that imputed fixed payment obligations resulting from nonutility power purchases impact SIGNUGs adversely, such changes should have an impact either on the capitalization ratios or on interest paid on debts.

There are no significant changes in the capitalization ratios of either group (Table 14 and Figure 6). One would normally expect that power purchase agreements, by eliminating the need to build, would lower the need for new capital expenditures in the SIGNUGs group and enable them to lower the debt component. The data do not reflect this decline, indicating that the need for capital expenditures might have been significantly higher if the SIGNUGs had decided to build rather than buy.

\section{Cost of Capital and Spread Between Debt and Equity}

As indicated earlier, holders of common equity need to be paid a higher rate of return than debt holders. The computed rates of return on equity and debt for SIGNUGs in 1986 were 12.9 percent and 9.1 percent, respectively, with a spread of 380 basis points (Table 14 and Figure 7). In 1992, this spread declined to 210 basis points. The corresponding spreads for NONUGs were 480 and 260 . These data indicate that the rate at which the spread declined was similar for the SIGNUGs and the NONUGs.

In the absence of any recognizable trend, various other factors need to be taken into account. These include the state of the economy, the growth in demand for electric power, the overall conditions in the financial markets, investor perceptions, and avenues for alternative investments. The key issue is whether the SIGNUGs are in a situation in which they are obligated to pay more to acquire capital-be it debt or equity. The evidence does not support this assumption unless it can be demonstrated that the SIGNUGs would have paid a still lower cost of capital in the absence of power purchases. During the period from 1986 to 1992 , the data show that the NONUGS earned a slightly higher rate of return on common equity (in five out of seven years) whereas the SIGNUGs paid a slightly higher interest rate on longterm debt than the NONUGs.

\section{Distribution of Earnings Between Common Equity and Debt}

A firm's total earnings can be divided into two parts: the part that must be paid to its debt holders as a first charge and the residual that accrues to the holders of equity. In 1992, 44.6 percent of the SIGNUGs' total earnings was used for payment of interest charges and 50.1 percent was available to the common equity holders (Figures 8 and 9). The corresponding figures for NONUGs were 43.3 percent and 51.9 percent, respectively. ${ }^{61}$ In other words, the SIGNUGs have paid slightly more of their income to meet debt charges than the NONUGs. With the exception of 1989, it can be seen that NONUGs were able to allocate a slightly higher percentage of total earnings to common equity. It is not clear whether the observed difference (of less than a percentage point) during 1991 and 1992 can be attributed to power purchases by the SIGNUGs.

\section{Net Electric Operating Income as a Share of Operating Electric Revenue}

The treatment of purchased power costs by a utility is straightforward. Regulatory authorities permit an exact pass-through of purchased power costs by a utility. Thus, retail sale proceeds of purchased power are embedded in the total electric revenue reported on the income statement, and payments to nonutility generators are expensed annually. Clearly, there are neither assets nor liabilities associated with these transactions. Thus, the SIGNUGs and NONUGs may have levels of operating revenues that are about equal but with differing shares of net electric operating incomes. In 1992, operating income was 16.1 percent of operating revenue for the SIGNUGs compared with 20.1 percent for the NONUGs. ${ }^{62}$ However, it may be difficult to attribute the entire difference to power purchases without taking into account the impact of additional factors contributing to this difference. ${ }^{6.3}$

\section{Electric Operating Incomes and Net Electric Plant}

SIGNUGs generally enjoyed a rate of return higner than the NONUGs when electric operating income is viewed

\footnotetext{
${ }^{6}$ Some investor-owned utilities have started indicating projected payments with respect to purchased power in their annual reports. This information, while useful, is not fully comprehensive.

${ }^{61}$ The computation takes into account interest paid plus net income in the denominator with net income minus payments for preferred in the numerator.

${ }^{62}$ The industry average for 1992 was 18 percent (Figure 4).

${ }^{63}$ Operating revenue as a share of net electric plant was 56.4 percent for the SIGNUGs and 43.9 percent for NONUGis in 1992 . Only a part of this difference may be due to power purchases.
} 
Table 14. Comparative Ratios and Indicators for SIGNUGs and NONUGs, 1986-1992

\begin{tabular}{|c|c|c|c|c|c|c|c|}
\hline Item & 1986 & 1987 & 1988 & 1989 & 1990 & 1991 & 1992 \\
\hline \multicolumn{8}{|l|}{$\begin{array}{l}\text { Components of Capitalization (percent) } \\
\text { SIGNUGs }\end{array}$} \\
\hline Long-Term Debt . . . . . . . . . . . & 48.3 & 48.9 & 50.6 & 50.1 & 49.7 & 49.4 & 48.5 \\
\hline Preferred Stock $\ldots \ldots \ldots \ldots \ldots$ & 8.6 & 8.5 & 8.1 & 7.9 & 7.8 & 7.3 & 7.5 \\
\hline Common Equity $\ldots \ldots \ldots \ldots \ldots$ & 43.1 & 42.6 & 41.3 & 41.9 & 42.5 & 43.2 & 44.0 \\
\hline Total Capitalization . . . . . . . . . . . & 100.0 & 100.0 & 100.0 & 100.0 & 100.0 & 100.0 & 100.0 \\
\hline \multicolumn{8}{|l|}{ NONUGs } \\
\hline Long-Term Debt . . . . . . . . . . . & 48.4 & 48.4 & 48.4 & 48.5 & 49.9 & 49.5 & 48.5 \\
\hline Preferred Stock $\ldots \ldots \ldots \ldots \ldots$ & 8.5 & 7.8 & 7.5 & 7.1 & 6.8 & 6.5 & 6.5 \\
\hline Common Equity $\ldots \ldots \ldots \ldots \ldots$ & 43.1 & 43.8 & 44.0 & 44.5 & 43.4 & 44.0 & 45.1 \\
\hline Total Capitalization . . . . . . . . . . & 100.0 & 100.0 & 100.0 & 100.0 & 100.0 & 100.0 & 100.0 \\
\hline \multicolumn{8}{|c|}{$\begin{array}{l}\text { Rate of Return on Components of Capitalization (percent) } \\
\text { Equity }\end{array}$} \\
\hline Signugs $\ldots \ldots \ldots \ldots \ldots \ldots$ & 12.9 & 11.5 & 9.5 & 12.5 & 10.5 & 10.8 & 11.0 \\
\hline Nonugs $\ldots \ldots \ldots \ldots \ldots \ldots$ & 13.6 & 12.6 & 9.7 & 10.2 & 10.2 & 11.5 & 11.8 \\
\hline \multicolumn{8}{|l|}{ Debt } \\
\hline Signugs $\ldots \ldots \ldots \ldots \ldots \ldots$ & 9.1 & 8.6 & 8.8 & 9.2 & 9.6 & 9.6 & 8.9 \\
\hline Nonugs $\ldots \ldots \ldots \ldots \ldots \ldots \ldots$ & 8.8 & 8.5 & 9.2 & 9.2 & 9.4 & 9.4 & 9.2 \\
\hline \multicolumn{8}{|c|}{ Spread Between Returns on Debt and Equity (Basis Points) } \\
\hline Signugs $\ldots \ldots \ldots \ldots \ldots \ldots \ldots$ & 380 & 290 & 70 & 330 & 90 & 120 & 210 \\
\hline Nonugs $\ldots \ldots \ldots \ldots \ldots \ldots$ & 480 & 410 & 50 & 100 & 80 & 190 & 260 \\
\hline \multicolumn{8}{|c|}{ Earnings on Common Equity as a Percent of Total Earned on all Capital Components } \\
\hline Signugs $\ldots \ldots \ldots \ldots \ldots \ldots \ldots$ & 50.8 & 49.8 & 43.5 & 50.1 & 45.3 & 46.8 & 50.1 \\
\hline Nonugs $\ldots \ldots \ldots \ldots \ldots \ldots$ & 53.6 & 53.3 & 45.5 & 47.1 & 45.8 & 49.0 & 51.9 \\
\hline \multicolumn{8}{|c|}{ Interest as a Percent of Total Earned on Capital Components } \\
\hline Signugs $\ldots \ldots \ldots \ldots \ldots \ldots \ldots$ & 40.4 & 42.5 & 49.4 & 44.0 & 48.5 & 47.4 & 44.6 \\
\hline Nonugs $\ldots \ldots \ldots \ldots \ldots \ldots$ & 38.8 & 39.6 & 47.5 & 46.7 & 48.5 & 45.9 & 43.3 \\
\hline \multicolumn{8}{|c|}{ Electric Operating Income as a Percent of Electric Revenue } \\
\hline$\ldots \ldots \ldots \ldots$ & 19.0 & 18.5 & 19.5 & 18.4 & 17.7 & 16.5 & 16.1 \\
\hline Nonugs ..... & 19.8 & 20.4 & 20.8 & 21.4 & 20.2 & 20.7 & 20.1 \\
\hline \multicolumn{8}{|c|}{ Operating Electric Revenue as a Percentage of Net Electric Plant } \\
\hline Signugs $\ldots \ldots \ldots \ldots \ldots \ldots \ldots$ & 46.1 & 45.3 & 46.7 & 49.1 & 51.9 & 54.5 & 56.4 \\
\hline Nonugs $\ldots \ldots \ldots \ldots \ldots \ldots$ & 39.8 & 39.6 & 40.6 & 41.4 & 42.0 & 44.5 & 43.9 \\
\hline \multicolumn{8}{|c|}{ Electric Operating Income as a Percent of Net Electric Plant } \\
\hline Signugs $\ldots \ldots \ldots \ldots \ldots \ldots$ & 8.8 & 8.4 & 9.1 & 9.1 & 9.2 & 9.0 & 9.1 \\
\hline Nonugs $\ldots \ldots \ldots \ldots \ldots \ldots$ & 7.9 & 8.1 & 8.4 & 8.9 & 8.5 & 9.2 & 8.8 \\
\hline \multicolumn{8}{|l|}{ Electric Revenue per Kilowatthour (cents) } \\
\hline Signugs $\ldots \ldots \ldots \ldots \ldots \ldots \ldots$ & 7.9 & 7.6 & 7.6 & 8.0 & 8.5 & 9.0 & 9.3 \\
\hline Nonugs $\ldots \ldots \ldots \ldots \ldots \ldots$ & 8.4 & 8.2 & 8.0 & 8.2 & 8.2 & 8.5 & 8.5 \\
\hline \multicolumn{8}{|c|}{ Electric Operating Income per Kilowatthour (cents) } \\
\hline Signugs $\ldots \ldots \ldots \ldots \ldots \ldots$ & 1.5 & 1.4 & 1.5 & 1.5 & 1.5 & 1.5 & 1.5 \\
\hline Nonugs $\ldots \ldots \ldots \ldots \ldots \ldots \ldots$ & 1.7 & 1.7 & 1.7 & 1.7 & 1.7 & 1.8 & 1.7 \\
\hline \multicolumn{8}{|c|}{ Annual Net Investment in Plant as a Percentage of Net Utility Plant } \\
\hline Signugs $\ldots \ldots \ldots \ldots \ldots \ldots \ldots$ & 9.9 & 8.7 & 8.9 & 7.8 & 8.0 & 8.0 & 8.3 \\
\hline Nonugs $\ldots \ldots \ldots \ldots \ldots \ldots$ & 9.0 & 8.1 & 6.7 & 6.4 & 6.3 & 6.4 & 6.3 \\
\hline
\end{tabular}


Table 14. Comparative Ratios and Indicators for SIGNUGs and NONUGs, 1986-1992 (Continued)

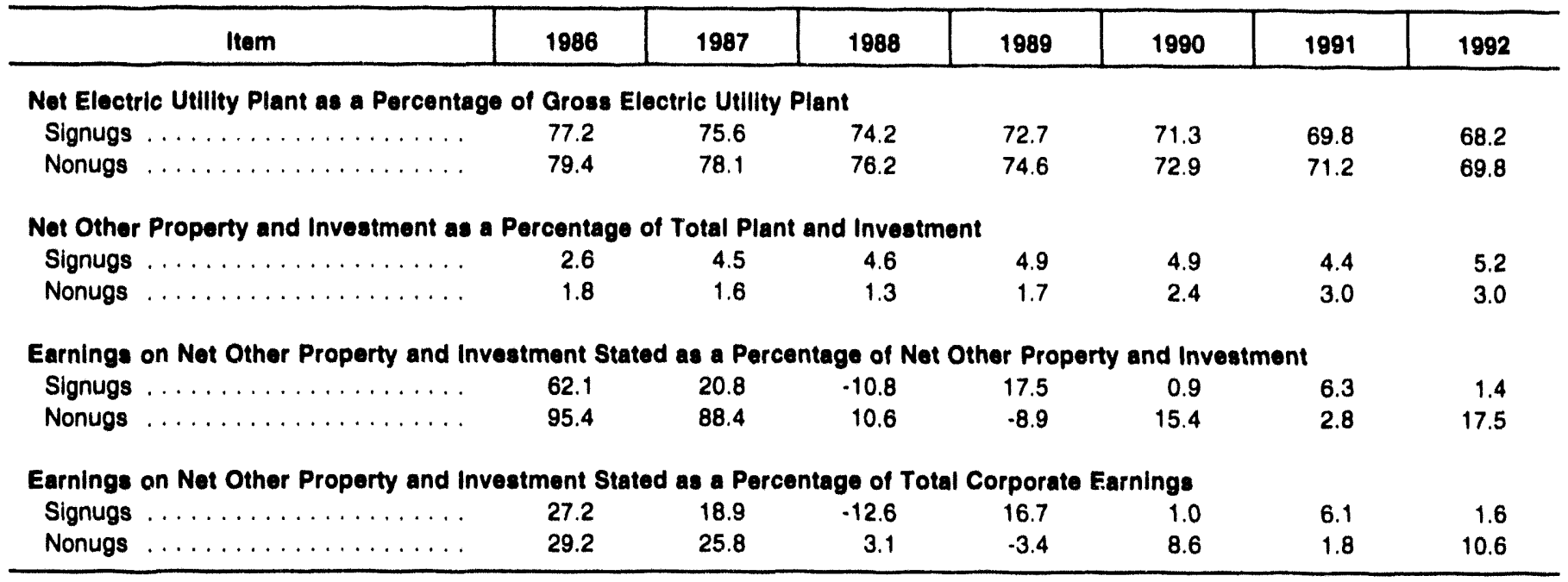

Note: The above ratios and indicators were calculated by using aggregated data in Tables 12 and 13 before rounding.

Source: Federal Energy Regulatory Commission, FERC Form 1, "Annual Report of Major Electric Utilities, Licensees, and Others" for 1992 and previous years.

Figure 6. Comparative Components of Capitalization Botween SIGNUGs and NONUGs, 1986-1992 (Percent of Total Capitalization)

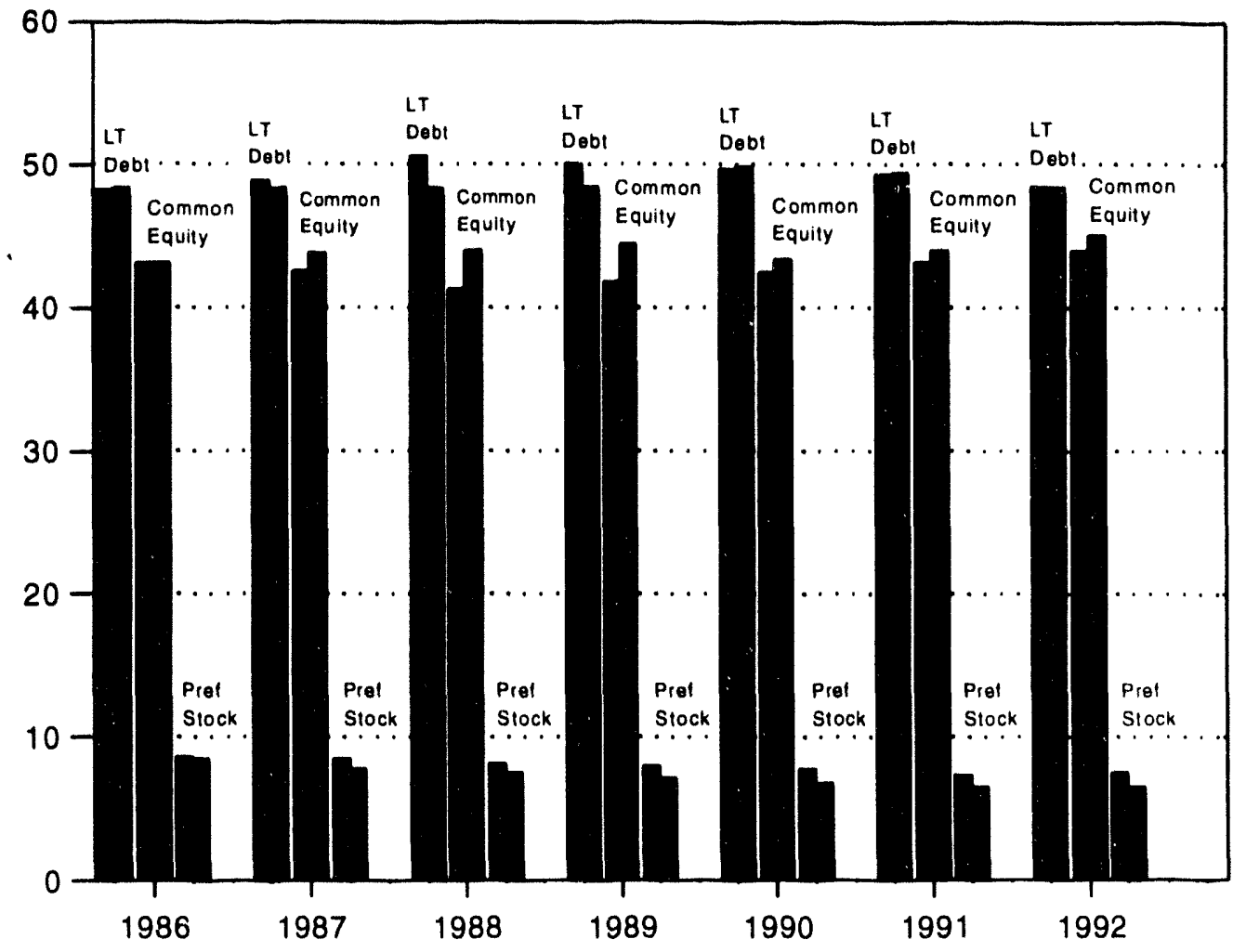

SIGNUGs NONUGs

LT Debt $=$ Long-term debt.

Pref Stock $=$ Preferred stock.

Note: Compiled by using data in Tables 12 and 13.

Source: Federal Energy Regulatory Commission, FERC Form 1, "Annual Report of Major Electric Utilities, Licensees, and Others" for 1992 and previous years. 
Figure 7. Average Cost of Debt, 1986-1992

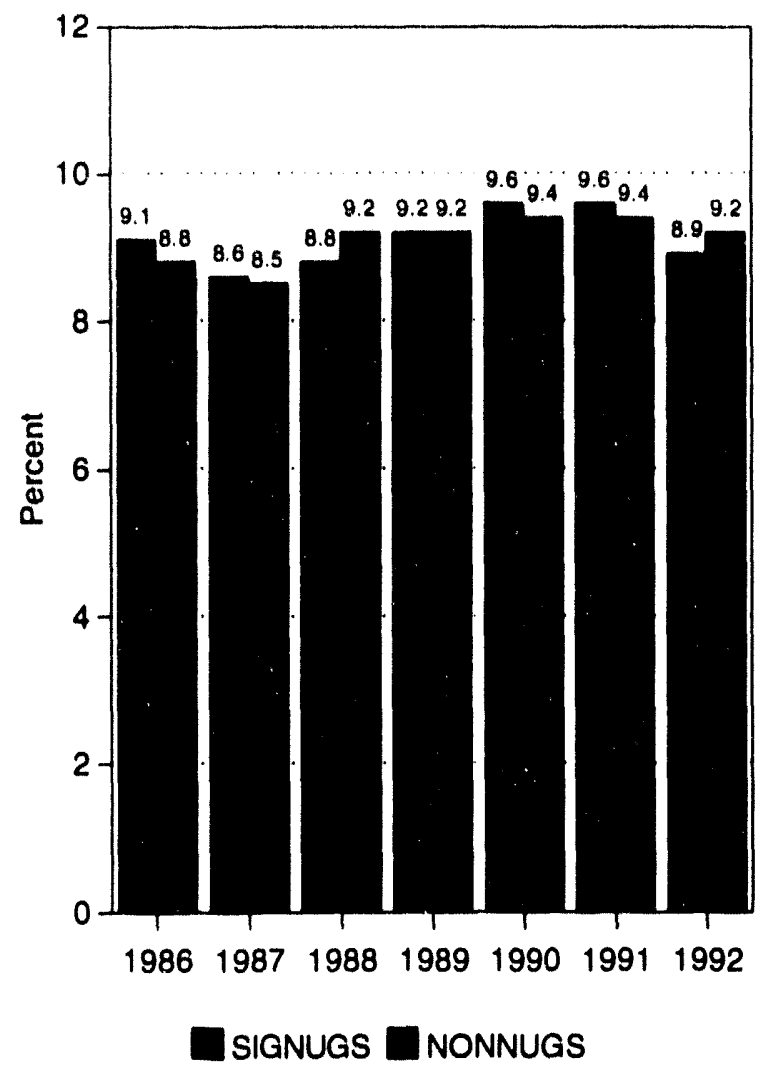

Note: Calculated from data in Tables 12 and 13.

Source: Federal Energy Regulatory Commission, FERC Form 1, "Annual Report of Major Electric Utilities, Licensees, and Others" for 1992 and previous years.

as a share of net electric plant (Table 14). Note that the difference (though small) has persisted since 1986 in all years except 1991 . While there is no discernible trend, one would expect the returns to be the same for both groups (since SIGNUGs make no profits on sales of purchased power). Greater involvement with shared facilities by the SIGNUGs may be a contributory reason. Another may simply be a measure of performance.

\section{Electric Revenue and Operating Income Per Kilowatthour}

Dividing total electricity sales into total revenues equals revenue per kilowatthour. A similar procedure can be
Figure 8. Percentage of Earnings Available for Common Equity, 1986-1992

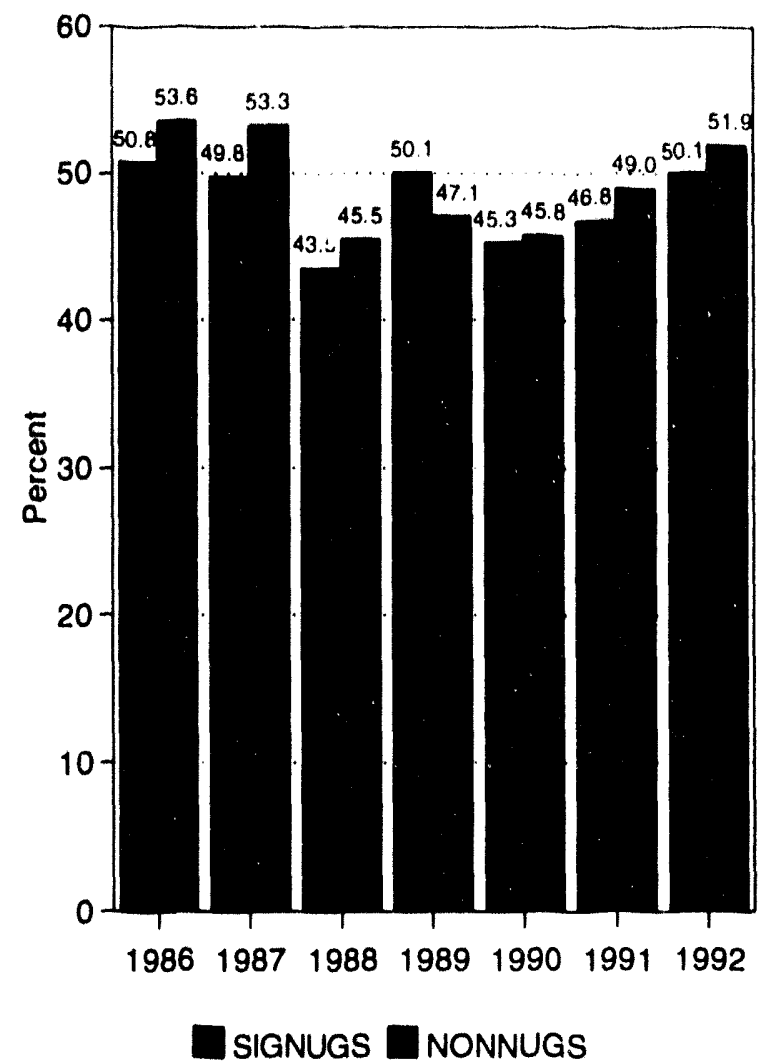

Note: Calculated from data in Tables 12 and 13.

Source: Federal Energy Regulatory Commission, FERC Form 1, "Annual Report of Major Electric Utilities, Licensees, and Others" for 1992 and previous years.

used to derive operating income per kilowatthour. SIGNUGs have been able to recoup more revenue per kilowatthour of sale than the NONUGs since 1990. In 1992, the SIGNUGs recouped an average of 9.3 cents per kilowatthour sold, and NONUGs secured 8.5 cents per kilowatthour. ${ }^{64}$ However, translating these data to get a measure of profitability on sales is not very helpful. Dividing electricity sales into operating income yields the residual after meeting production related operations and maintenance expenses. This may be treated as a rough measure of profitability per kilowatthour of electricity sold. The available data indicates that this measure was 1.7 cents per kilowatthour for the NONUGs and 1.5 cents for the SIGNUGs in 1992. This implies that the NONUGs have a higher rate of profitability per kilowatthour than the SIGNUGs.

\footnotetext{
${ }^{64}$ It may be noted that the composition of utilities in the SIGNUG group is dominated by utilities in the northeast and the west. Utilities in these regions have higher per kilowatthour generation costs in comparison with those in other regions. This may explain the higher level of revenue per kilowatthour for the SIGNUGs.
} 
Figure 9. Interest Expenses as a Percentage of Earnings, 1986-1992

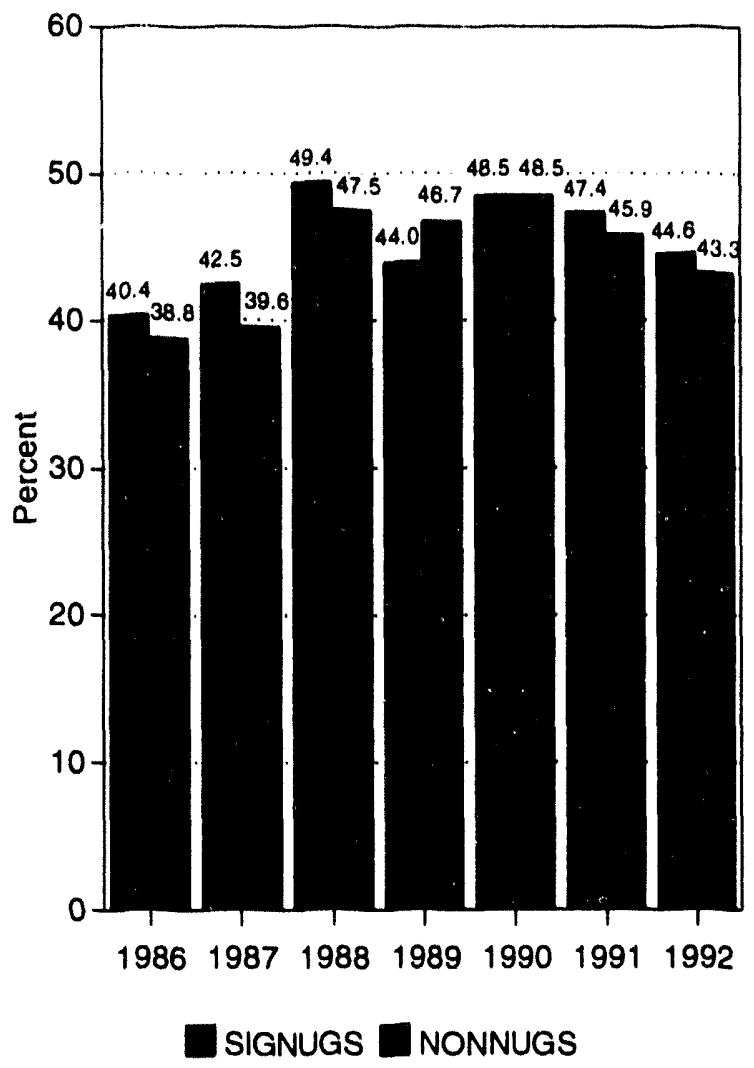

Note: Calculated from data in Tables 12 and 13.

Source: Federal Energy Regulatory Commission, FERC Form 1, "Annual Report of Major Electric Utilities, Licensees, and Others" for 1992 and previous years.

\section{Net Electric Plant}

Investment levels, computed as a percentage of net electric utility plant, have declined for both groups during the period from 1986 to 1992 (Table 14 and Figure 10). The overall rate of decline is, however, higher for the NONUGs (30 percent) than for the SIGNUGs (17 percent). The NONUGs' decline, which is in keeping with the industry trend of declining investments (Table 5) requires no explanation. The lower rate of decline for the SIGNUGs may well imply that their investment levels would have been still higher but for power purchases. In any case, power purchases did not lead to a significant reduction in investment levels of the SIGNUGs.
Figure 10. Capital Expenditures as a Percentage of Net Utility Plant, 1986-1992

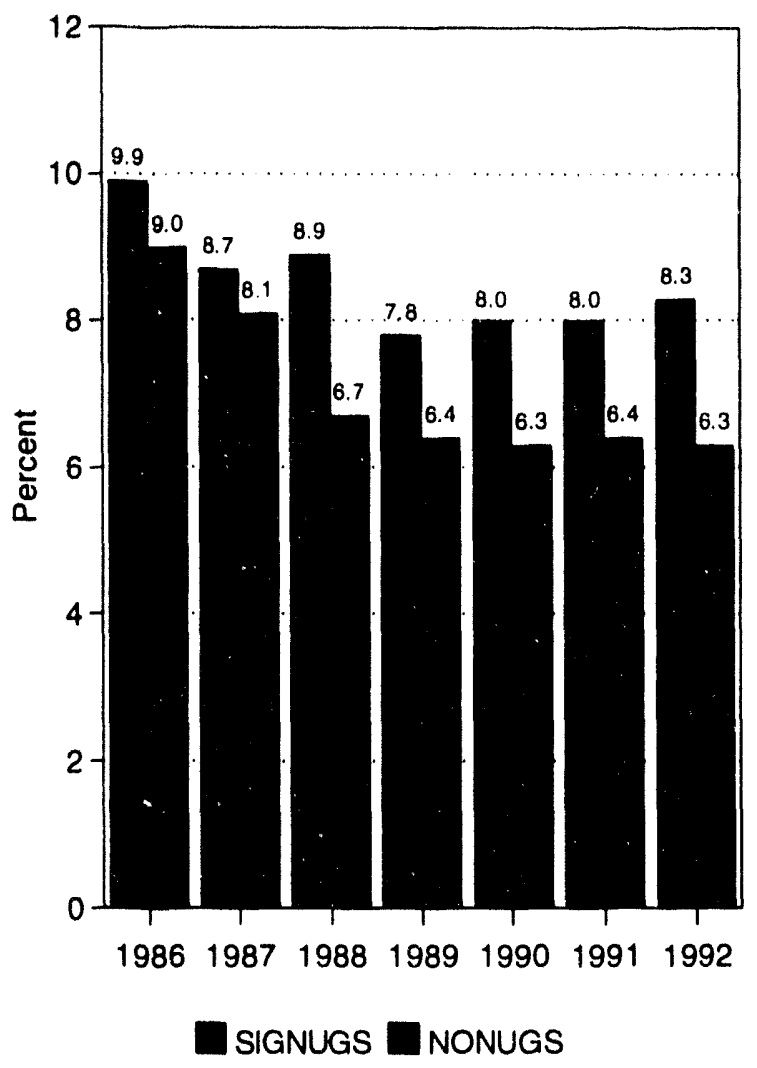

Note: Calculated from data in Tables 12 and 13.

Source: Federal Energy Regulatory Commission, FERC Form 1, "Annual Report of Major Electric Utilities, Licensees, and Others" for 1992 and previous years.

The rate at which investments are made annually has an impact on the gross and net value of total utility plant on a utility's balance sheet. Assume the value of gross utility plant to be 100 at any benchmark date and assume (for the sake of simplification) that no further investments take place. With passage of time, the net value would keep going down as a result of continuing depreciation. Thus, the spread between gross plant and net plant book value provides some information not only on continuing investment activities but also on the aging process of plants in service. ${ }^{65}$ The ratio of net to gross plant value has declined since 1986 for both groups. The implication may be that power purchases have not brought about a significant difference in the investment in new plant and equipment expenditures for either group.

\footnotetext{
${ }^{65}$ In the example above, assuming a straight-line depreciation method with plant life assumed to be 30 years, gross and net plant valuations would be $100 / 67$ after a 10 -year period.
} 


\section{Conclusions}

The preceding analysis precludes the determination of definite trends for the group of utilities that buy significant power from nonutility generators. Capitalization ratios for both groups of utilities do not show material differences. The data failed to support the hypothesis that utilities with significant power purchases incurred a higher cost of capital than the utilities without such a commitment. In fact, the evidence shows that utilities with little or no power purchase commitments had to bear a slightly higher cost of capital in comparison with the cost borne by the other group.

Note, however, that the issue of the financial impact of nonutility power purchases has come to the forefront only since 1990 . It is thus possible that sufficient time has not elapsed for a meaningful determination to be made. It is also possible that deficiencies in the evaluation process mask conclusions that may otherwise be drawn. All that can be stated with reasonable confidence is that there is a need to monitor financial developments in both groups more closely. The regulatory authorities can assist this process by formulating disclosure requirements that permit assessments to be made with transparency.

\section{Impact of Power Purchases from Nonutilities on the Utility Cost of Capital: An Empirical Evaluation}

This section summarizes the results of an econometric analysis of the impact of long-term power purchases on a utility's cost of capital from the perspective of the equity markets, rather than the debt markets. ${ }^{66}$

There are several reasons for adopting the above approach. First, the debt and equity markets are linked. If nonutility generation contracts really are equivalent to debt, then they raise the risk of the firm, and this should be observable in the equity market. Studying utility stock price performance has the advantage of avoiding some of the circularity in the discussion of bonds, i.e., if the bond-rating agencies declare that a certain risk exists, it becomes a self-fulfilling prophecy. ${ }^{67}$ By observing the reaction of the equity markets, the intent is to verify if shareholders perceive a financial risk from long-term nonutility power purchases. Since the cost of equity (and associated taxes) is the largest part of the overall cost of capital, any assessment of the utility's cost of capital should consider this market explicitly. ${ }^{68}$

Financial markets absorb relevant information about the risks facing firms and adjust prices to reflect these judgments. This happens whether there are explicit reactions from industry spokesmen or not. For example, secondary market prices for bonds of electric utilities which had nuclear power assets reacted unfavorably to the Three Mile Island accident even if there was no direct risk to credit quality. ${ }^{69}$

\section{Cost of Equity Capital Estimation}

There is no generally accepted measure of the cost of equity capital, but only a number of competing theories that are more or less capable of being applied numerically. Three approaches used as proxy measures for the cost of equity capital are derived from: (1) a discounted cash flow model, (2) the earnings price ratio, and (3) the capital asset pricing model (CAPM). All of these methods rely primarily on stock market prices, but require additional data that must be estimated in particular cases as well. Each of these methods is reviewed below.

The discounted cash flow method is an application of the standard present-value calculation to the market price of a utility stock, based on its expected dividends and their rate of growth. The earnings price ratio, as a measure of cost of equity carital, is the same as the discounted cash flow model formulation but with the growth in dividends assumed to be exactly the ratio of retained earnings to the market value or price of the

\footnotetext{
${ }^{6}$ The results presented in this section are based on work performed at the Lawrence Berkeley Laboratory, with funding provided by the Energy Information Administration. Dr. Edward Kahn, the principal investigator, supported by Steven Soft and Timothy Belden, participated in the research and in providing the results. See Appendix $C$ for a detailed discussion.

${ }^{67}$ The judgement of the rating agencies by itself will increase the cost of bonds, making the bond market appear to confirm their predictions, although this will not affect actual risk.

68 The typical capital structure of investor-owned utilities consists of about 50 percent of debt and the remainder in equity, i.e., common and preferred stock. Note, however, that dividends on stocks are paid from net income, after payment of taxes. Interest payments on debt are tax deductible.

${ }^{69}$ W. Barrett, A. Henson, and R. Korb, "The Effect of Three Mile Island on Utility Bond Risk Premia: A Note," Journal of Finance, Vol. 41, No. 1 (March 1986), pp. 255-261.
} 
stock. The CAPM approach is grounded in economic and financial theory. Based on a model of investor behavior and market valuation, standard business school textbooks on corporate finance favor this approach. ${ }^{70}$ The principal advantage of the CAPM is that it provides a precise and measurable definition of risk as applied to stocks. The risk measure, called beta, is proportional to the correlation between the rate of return of a particular asset with the rate of return for the market as a whole. ${ }^{71}$ This measure of risk is then related in a straightforward fashion to the cost of equity capital through the basic CAPM equation.

The CAPM asserts that the expected rate of return is just the risk-free raie plus a risk premium multiplied by "the market price of risk." The market price of risk is the difference between the expected rate of return for the market as a whole and the risk-free rate of return. The stockholders' expected rate of return, as estimated by the CAPM, is assumed to represent the cost of equity capital.

Some clarification is necessary to explain why these measures are expected to reflect the changes in the cost of equity capital caused by contracts to purchase power from nonutility generators or commitment to capital expansion. The case of the second estimator (earnings price ratio) is most straightforward; if stockholders believe that the utility's future earnings are made more risky by its commitments, then the price of stock will fall. This argument also holds for the first estimator (discounted cash flow model), but in this case there is an additional effect which works through the estimate of future growth rate of dividends. Since this estimate is provided by market analysts, their judgment concerning the impact of the utility's commitments will play a role independent of stockholder's views. The third estimator (CAPM) can only be affected through the measure of risk-beta. Since any fluctuation in earnings must be absorbed by stockholders (i.e., the creditors having a prior claim), increasing the debtequity ratio reduces the base over which these fluctuations are spread. ${ }^{72}$ Also, since the prices depend on earnings per share, and having a smaller base means greater percentage fluctuation in earnings per share, it also means greater fluctuations in the stock price. This in turn leads to a larger beta. Thus, anything that effectively increases a utility's debt-equity ratio should also increase its beta.

\section{Problem Formulation}

Electric utilities have the option to construct their own power plants or contract for long-term power from a nonutility generator. The utility construction alternative, however, is also not without financial risk. Firms may have to sell securities that will reduce interest coverage for bonds and dilute earnings for shareholders. During the last major round of utility construction, these burdens proved substantial. Additionally, the risk of regulatory disallowances had a negative effect on utility finances. One study of the utility cost of capital, which examined data for 1983 and 1984, found that forecasted construction expenses had a significantly negative effect on the market to book value ratio for a sample of 30 electric utility stocks. ${ }^{73}$

Therefore, to analyze if power purchases tend to increase equity capital costs, each econometric model of the cost of equity capital (discounted cash flow, earnings price ratio, and CAPM) includes three independent variables: the debt/equity ratio, projected capital expenditures, and imputed debt resulting from nonutility power purchases. ${ }^{74}$ Appendix $C$ provides a detailed discussion of the measurement issues, methodology, data, and regression results.

\section{Regression Analysis Results}

Based on an analysis using the discounted cash flow model, the earnings-price ratio model, and capital assetpricing model method, there does not appear to be any evidence to support the hypothesis that nonutility power purchases are equivalent to debt. At least as far as the cost of equity capital is concerned, there is more evidence to support the notion that utility construction raises the cost of capital more than nonutility power purchases do. This finding tends to support arguments made by nonutility generators on this issue. ${ }^{75}$ This

\footnotetext{
${ }^{70}$ R. Brealey and S. Myers, Principles of Corporate Finance, 4th Edition (New York, NY: McGraw-Hill Inc., 1991).

${ }^{71}$ The proportionality constant is the ratio of the standard deviation of the asset's rate of return to the standard deviation of the rate of return for the market as a whole.

${ }^{72}$ For a full discussion of this effect, see L. Kolbe, J. Read, and G. Hall, The Cost of Capital: Estimating the Rate of Return for Public Utilities, Appendix A (Cambridge, MA: MIT Press, 1984), pp. 137-146.

${ }_{73}$ Putnam, Hayes and Bartlett, Inc., Are Regulatory Risks Excessive? A Test of the Modern Balance Between Risk and Reward for Electric Utility Shareholders, report prepared for the Division of Coal and Electricity Policy, U.S. Department of Energy (Washington, DC, May 1986), pp. $1-50$.

${ }^{74}$ All independent variables are normalized.

${ }^{75}$ R. Naill, and B. Sharp, "Risky Business? The Case for Independents," The Electricity Journal, Vol. 4, No. 3 (April 1991), pp. 54-63.
} 
conclusion is supported by reasonably strong statistical results from the CAPM specification. There was no confirmation of this result from the discounted cash flow model specification. The results of the earnings price ratio model appear to suggest that utilities can earn more than the cost of capital for new construction, even if construction activity is risky and therefore somewhat more costly than purchasing from nonutility generators. The results indicate nothing about the source of the risk associated with projected construction expenditures. It is entirely possible that it lies with the regulator, rather than with the firm.

If these results are correct, they imply that the "buy versus build" debate, insofar as cost of capital questions are involved, is not about the impacts of nonutility power purchases on the ratepayer, i.e., the consumer. Rather, the results suggest that this debate is really about the long-run prospects for shareholder earnings, i.e., that it is a market share conflict between the debt and equity holders.

\section{Conclusions}

This chapter analyzed the impact of nonutility power purchases on a utility's cost of capital by adopting two different methodologies. However, both failed to provide evidence to definitively establish that nonutility power purchases increase a utility's cost of capital. There is evidence to show that construction projects increase risk and raise a utility's cost of capital. New construction projects are also associated with an increase in earnings which may be more than the increase in the cost of capital. These results could, however, change with the passage of time and with the availability of additional data. Modifications of existing disclosure requirements with respect to off-balancesheet obligations by appropriate regulatory authorities would permit conclusions to be drawn more easily than is now possible. 


\section{Purchased Power Debate and the Energy Policy Act of 1992}

\section{Background}

Congress passed the Public Utility Regulatory Policies Act of 1978 (PURPA) as one part of the five-part major national energy package called the "National Energy Act." As indicated in Chapter 2, PURPA's provisions affected the regulated utilities in several critical areas. $^{76}$

With respect to electric utilities, PURPA established standards to encourage energy conservation, efficient use of facilities and resources, and equitable retail rates to electric consumers. In addition, PURPA also encouraged the use of cogeneration and small power production by requiring electric utilities to interconnect with and purchase power from facilities designated as "qualifying facilities" (QFs) by the Federal Energy Regulatory Commission (FERC). The legislation further stipulated that the utilities pay for such power purchases at approximately their incremental cost of alternative electric energy or the "avoided cost" of power production.

By encouraging nonutility power generation and by making such output easily marketable on a wholesale basis, PURPA's provisions introduced several farreaching operational and regulatory changes in the electric utility industry. In the evolving wholesale market for electric power, PURPA's most notable contribution was to introduce competition while taking future supply options into account.

Available data show that nonutility generating capacity increased from 17.4 gigawatts in 1979 to 56.8 gigawatts at the end of 1992, reflecting an average annual growth rate of 9.5 percent. $^{77}$ In contrast, industry capacity during the same period increased from 598.3 gigawatts to 741.7 gigawatts or at about 1.7 percent annually (Table 2). Thus, by the end of 1992 , nonutility power producers accounted for 7.1 percent of the industry's total installed capacity.

Analysts contend that significant nonutility additions to generating capacity are likely to continue in the future. Based on capacity additions in recent years and reports of expected future additions, there are projections that nonutilities will likely provide a major share of the new generating capacity in the future. ${ }^{78}$

Several factors contributed to the rapid growth in nonutility capacity and generation. Some investorowned utilities that had confronted financial difficulties (as a result of having initiated construction projects during the 1970s) were happy to enter into power purchase agreements to acquire incremental power supplies from nonutility generators, where necessary. In some States, the regulatory authorities granted favorable treatment to nonutility generators, spurring their rapid growth. More recently, several States have initiated competitive bidding for new generating capacity as part of a least-cost planning process and as a substitute for "avoided cost" determinations.

The development of nonutility generation, however, has not been an unmixed blessing. The utilities complained that they were forced to buy power even when the need for capacity did not exist. The computation of avoided costs by the State regulatory authorities in States like California or New York were deemed to be too high. ${ }^{79}$ To add to these woes, the bond-rating agencies commenced treating portions of financial liability associated with purchased power agreements as fixed payment obligations akin to debt. Inclusion of these obligations in the debt portfolio of a utility may

\footnotetext{
${ }^{76}$ Appendix D contains selected provisions of the Public Utility Regulatory Policies Act of 1978 (as amended).

${ }^{77}$ Energy Information Administration, The Changing Structure of the Electric Power Industry 1970-1991, DOE/EIA-0562 (Washington, DC, March 1993), Table C7, p. 87, and Energy Information Administration, Electric Power Annual 1992, DOE/EIA-0348(92) (Washington, DC, January 1994), p. 119.

${ }^{78}$ Jerome L. Glazer and Daryl Hartnett, "Opportunities and Challenges for Developers and Power Purchasers," paper presented at the Panel on PUHCA Reform and the National Energy Act (Boston, MA, June 1993).

${ }^{79}$ For specific details of avoided cost computation in New York and California, see Orkand Corporation, Non-Utility Pricing Analysis: Estimation of Avoided Cost for Individual Utility (Silver Spring, MD, February 28, 1990).
} 
tend to lower its interest coverage ratio and may lead to a lowering of its bond-rating. The utility so affected may be required to pay a higher capital cost in meeting its financing needs in the market. Alternatively, the affected utility must suitably readjust its capitalization structure or secure rates of return compatible with higher imputed debt levels.

Nonutility generators question the validity of the above line of reasoning by asserting that they absorb many of the risks associated with the construction of new power plants. Accordingly, power purchase agreements should lead to an improvement in the credit rating of a utility purchasing power.

While the above debate is still ongoing, the recently enacted Energy Policy Act of 1992 (EPACT) contains several provisions that amend the Public Utility Holding Company Act (PUHCA), the Federal Power Act (FPA), and PURPA provisions in areas that govern, among others, the future of nonutility generation and the associated wholesale power transactions. Briefly, the

\section{EPACT:}

- Creates a new category of power suppliers by amending the PUHCA. EPACT exempts from most of the corporate ownership and geographic provisions of the PUHCA an "Exempt Wholesale Generator (EWG)" and designates the Federal Energy Regulatory Commission as the authority to determine the EWG status of eligible facilities. These provisions will make it easier for the EWGs to compete in supplying incremental electric power requirements in the future (Section 711, Title VII - Electricity, Subtitle A - Exempt Wholesale Generators).

- Overhauls provisions of the Federal Power Act governing availability of transmission services to other producers by instructing the Federal Energy Regulatory Commission to order wholesale wheeling if such an order does not violate State laws or affect reliability (Section 721, Title VII - Electricity, Subtitle B - Federal Power Act: Interstate Commerce in Electricity).

- Amends PURPA by adding standards to its Section 111 regarding integrated resource planning, investments in conservation and demand-side management activities, and energy investments in power generation and supply; and stipulates provisions for protection of small businesses ${ }^{80}$ (Section 111, Title I - Energy Efficiency, Subtitle B Utilities).

- Requires States to consider four new ratemaking standards regarding the purchase of wholesale power by amending Section 111 of the PURPA regulations. The new standards include consideration of the effects of long-term wholesale power purchases on utility cost of capital and on retail rates, consideration of the leveraged capital structures on the reliability of wholesale power sellers, consideration of advance approval or disapproval of long-term wholesale power supply and the consideration of adequate fuel supplies in long-term power purchase contracts ${ }^{81}$ (Section 712, Title VII - Electricity, Subtitle A - Exempt Wholesale Generators).

PURPA Section 111 (a) requires each regulatory authority to consider the Federal standards as indicated above and to make a determination concerning whether it is appropriate to implement such standards to carry out the purposes of PURPA Title I concerning retail regulatory polices for electric utilities. ${ }^{82}$

EPACT imposes deadlines for completion of the evaluation and determination of the standards in several areas. Regarding the Section 712 standards, the EPACT mandates that each State regulatory authority consider and determine whether it is appropriate to implement the standards concerning the long-term wholesale power purchases not later than 1 year after the date of

\footnotetext{
${ }^{81}$ Section 111 (Title 1, Subtitle B - Utilities) of EPACT deals with encouragement of investments in conservation and energy efficiency by electric utilities. Included in this section are three efficiency standards that are amendments to PURPA Section 111 . These require: (i) consideration of integrated resource planning (IRP) that compares supply and demand-side options on a systematic basis; (ii) consideration of cost recovery for energy conservation, demand-side management (DSM), and energy efficiency programs and measures that are at least as profitable; (iii) consideration of rates that provide incentives for investments in cost-effective improvements in energy efficiency of power generation. The State commissions are to consider each of these issues within a 2-year period ending on October 23, 1994. Other provisions of this Subtitle deal with similar provisions as applicable to Federal power marketing boards and natural gas utilities.

${ }^{81}$ Details of EPACT Section 712 are provided later in this chapter. Also, see Appendix A.

${ }^{82}$ Section 101, Title I, "Retail Regulatory Policies for Electric Utilities," Subtitle A - General Provisions of the PURPA legislation states that the purposes (of PURPA) are to encourage: (1) conservation of energy supplied by electric utilities; (2) the optimization of the efficiency of use of facilities and resources by electric utilities; and (3) equitable rates to electric consumers.
} 
the amendment, i.e., October 23, 1993. Note that the State regulatory authorities have the option of adopting, in whole or in part, or rejecting completely the Section 712 standards. In addition, where a State regulatory authority decides it is not necessary to perform a general evaluation of any one or more of these issues, it should state the reasons in writing and make the statement available to the public. However, most States have since completed the evaluation process with respect to the four Section 712 standards (to Section 111 of the PURPA legislation) in conformity with the procedures outlined in the statutes.

This chapter examines the range of issues involved in connection with purchase power contracts and the extent to which they are likely to be resolved within the suggested regulatory framework. It also presents an overview of the debate as gleaned from the various Section 712 proceedings before the State regulatory authorities. Finally, it looks at the actions taken by various States regarding adoption and implementation of proposed Section 712 standards. Within the context of these developments, some indications regarding the future of the electric utility industry are also discussed.

\section{Section 712 of the Energy Policy Act of 1992}

Section 712 of the EPACT requires that to the extent a State regulatory authority requires or allows electric utilities (for which it has the ratemaking authority) to consider the purchase of long-term wholesale power supplies to meet demand, such authority shall perform a general evaluation (not later than 1 year after the date of enactment of EPACT) of:

(1) The potential for increases or decreases in the cost of capital for utilities, and any resulting effect on the retail rates paid by electric consumers from purchases of long-term wholesale power supplies in lieu of constructing new facilities by such utilities.

(2) Whether the use by exempt wholesale generators (EWGs) of capital structures that employ proportionately greater amounts of debt than the capital structures of regulated utilities, threatens reliability or provides an unfair advantage for EWGs over such utilities.

(3) Whether the State regulatory authorities should implement procedures for advance approval or disapproval of the purchase of a particular longterm wholesale power supply.

(4) Whether the State regulatory authorities should require, as a condition for the approval of longterm power purchases, a reasonable assurance of adequate fuel supply.

Note that the above four issues (with respect to which Section 712 of the EPACT stipulates PURPA standards) have already been the subject of controversy for some time. The relevance of Section 712 is to force State regulatory authorities to focus on issues that are critical to the future of the electric utilities and the independent power suppliers. These issues are discussed below.

\section{Impact of Purchased Power on Utility Cost of Capital}

As contracting for power became more common during the late 1980s, the bond-rating agencies commenced evaluating the risks associated with this activity on the bond-rating of utilities buying purchased power. One way to estimate the risk is to compute the fixed payment obligations involved, and include them in the balance sheet by suitably adjusting the level of debt in a utility's capitalization. The resulting changes in leverage then could be estimated together with their impact on interest coverage ratios. Other things being equal, the inclusion of imputed obligations for power purchase contracts increases a utility's debt, lowers its interest coverage ratios and, in some cases, its bondrating. With lowered bond-ratings, the affected utility's cost of external capital acquisition increases-both for debt and equity sales. Variations of this basic technique interject qualitative aspects of power purchase agreements and apportion only a part of fixed payments as debt equivalents.

\section{Treatment of Purchased Power by Rating Agencies}

The treatment of purchased power by the rating agencies has undergone evolutionary changes in response to changes in contracting procedures. The assessment of financial integrity and the associated bond-rating involves the evaluation of various factors based on analytical judgement and perception. The method of computing the debt component of purchased power, therefore, differs from one bond-rating agency to another and reflects their judgement of what should be included and what should be excluded in the computation. In the process, both qualitative and quantitative 
variables are used to assign ratings. Some of these nuances can best be clarified by examining the basic elements of the methodologies used by principal bondrating agencies.

- Standard and Poor's (S\&P) focuses on the utility rate base and the related earning capacity, both of which tend to diminish as purchased power increasingly replaces self-generated power. Next, the impact of purchased power contracts is assumed to increase operating leverage of a utility with its magnitude depending on the nature of the purchase contract, i.e, take-or-pay or take-andpay. In S\&P's view, the purchased power risk increases when a utility relies on nonutility generated power for more than 10 percent of its capacity needs. S\&P collects information on purchased power from utilities on a confidential basis. It then computes the net present value of future annual capacity payments (discounted at 10 percent) as a potential debt equivalent. However, only a portion of this amount is added to the utility's balance sheet on the premise that the entire portion of the contractual arrangement does not constitute debt. The percentage added is a function of S\&P's qualitative analysis of specific contracts and the extent to which market, operating, and regulatory risks are borne by the utility. For unconditional take-or-pay contracts, the range is from 40 to 80 percent with an average of 60 percent. The range for take-and-pay performance contracts is between 10 and 50 percent. $^{83}$

- Moody's recognizes that there are a number of clear benefits a utility can gain by entering into purchased power commitments. However, these commitments also cause an erosion in a utility's financial flexibility. Assessment by Moody's, therefore, focuses on the obligations and risks assumed as well as the utility's own unique situation. Included in this approach are the utility's generating mix and reserve capacity, the relative type and size of its purchased power commitments, and the nature of the obligations inherent in the contracts used to support such transactions.

In quantifying the debt component and the annual interest charge, Moody's applies certain estimating procedures to publicly available data. The capacity charge is assumed to be 60 percent of the purchased power expense, the debt component is determined by multiplying the capacity charge by a factor of 6.5, and the interest component is assumed to be 10 percent of the debt component. Thus, where the annual power purchased expense is $\$ 5,000$, the capacity charge is $\$ 3,000$, the debt component is $\$ 19,500$ and the interest component $\$ 1,950 .^{84}$

- Fitch emphasizes a qualitative approach rather than a quantitative one. This approach takes into account the distinctiveness of the projects, variations among the purchased power agreements, and differences in State regulation. The greater emphasis is on project fundamentals, with debt leverage and interest calculation used as a supplement. Future payment streams for capacity or demand charges (and in some cases energy charges) are computed first. The aggregate amount so derived is discounted by the utility's average cost of debt, and the resulting number is added to the utility's outstanding debt and other contractual obligations to provide an indication of leverage. Fitch notes that well-designed purchase programs "that demonstrate good project diversity and favorable economics" should not impact ratings. ${ }^{85}$

- Duff and Phelps considers a third of the capacity payments as interest regardless of the nature of the contracts (i.e., take-or-pay or take-and-pay), and debt equivalence is calculated by multiplying the imputed interest by a factor of 10 . These equivalents are used to adjust coverage and capital ratios to analyze the quantitative aspects of a utility's creditworthiness. In addition, several qualitative factors are also taken into account. These include: types of generation behind a utility's purchased power contracts, contract terms, the reliability of power source, the cost of power, and the need for capacity.

Regardless of the differences in methodology (and the modifications that bond-rating agencies have either introduced or are in the process of adopting), the common element is that power purchase agreements

\footnotetext{
${ }^{83}$ Standard and Poor's, "Utility Rating Criteria," Standard and Poor's CreditWeek (October 11, 1993), pp. 7-14.

${ }^{84}$ Moody's Investor Services, "Purchased Power Commitments and Their Impact on Investor-Owned Electric Utility Credit Quality" (August 1992), and "Moody's Continues to Weigh The Credit Risks of Purchased Power On Electric Utility Quality" (September 1992), pp. 1-10.

${ }_{85}$ Fitch Investor Service, Inc., "Purchased Power Benefits and Risks" (March 1993), pp. 1-4.

${ }^{86}$ Duff and Phelps, "The Power Purchase Commitment: General Industry Report" (October 1992), pp. 1-6.
} 
lead to an imputed increase in the debt component and in interest payable by a utility. The combination of these two factors brings about the danger of a potential downgrade. In such a case, there will thus be (at least in theory) an impact on cost of capital of the utility. ${ }^{87}$

\section{Views of Independent Power Producers}

Independent power producers (IPPs) are reluctant to accept the view that power purchase agreements have the impact of raising a utility's cost of capital. They point out that there are risks regardless of whether a utility buys power or builds its own plant. It is submitted that a utility loses its financial flexibility when it chooses to build large-scale plants. In support of this argument, references are made to the financial difficulties of the investor-owned utilities in the aftermath of the oil embargo in 1973-1974. ${ }^{88}$

The IPPs maintain that an increase in the debt-equity ratio (which may contribute to a utility's bond downgrade) can be due to several factors that are explicitly recognized by the rating agencies. ${ }^{89}$ Of these, power purchase obligations are just a part. Thus, the precise impact of any power purchase agreement, on a utility's creditworthiness is difficult to determine.

Evidence has been offered to show that ratings of utilities that bought power would have been even lower if they had exercised the option of building the facilities on their own. ${ }^{90}$ Virginia Power contracts for nearly 4,000 megawatts of capacity or about 20 percent of its total capacity. ${ }^{91}$ Its contract provisions for purchased power are carefully designed and include various safeguards that ensure the availability of least-cost power. ${ }^{92}$ Virginia Power ${ }^{93}$ officials maintain that had the utility constructed the required capacity, its bondrating would have gone down further and earlier in time. In addition, there has been little or no impact on its borroving costs subsequent to a recent downgrade in its ratings. ${ }^{94}$

The IPPs contend that demand risks are the same whether the utility buys power or builds required capacity. The construction, operating, and regulatory risks are lower when a utility buys in comparison with its build decision. If these assumptions are correct, then the utility's decision to buy is preferable to a build decision. This conclusion is based on the assumption that the buy decision leads to a shifting of the risks away from the utilities. ${ }^{95}$

The IPPs add that power purchase contracts are not the precise equivalents of debt instruments. It is pointed out that the recent power purchase contracts are mostly performance-based, so that no payments need be made where there is no performance. The risk to a utility is further reduced because the costs of purchased power are passed through to the ratepayers on a dollar-fordollar basis. Where the regulatory climate is supportive,

\footnotetext{
${ }^{87}$ There exist cases where a utility with purchases less than the norm of 10 percent had its bond-rating lowered. In connection with EPACT Section 712 hearings at the Idaho Public Service Commission in Boise, Idaho, it was stated that Idaho Power Company's purchases from nonutility generators were about 4 percent of power supply (total generation); however, these nonutility purchases accounted for about 30 percent of the Company's power supply costs, which led to a lowering of its bond-rating (Idaho Public Utilities Commission, Case No. GNR-E-93-6, Order No. 25218 dated October 22, 1993).

${ }^{88}$ These included problems of construction work in progress, cost overruns, excess capacity, prudence reviews, disallowances, phase-ins, and others as discussed in Chapter 2.

${ }^{89}$ Rating agencies invariably include a number of causal factors besides the adjusted debt-equity levels in downgrading a utility's rating . Other contributory factors are a weak economy responsible for poor sales, investments in recently built expensive plants, inability to earn authorized rates of return, projected environmental costs, and aggressive conservation and load management activities. Nearly all utilities in the Northeast face all or some of these problems in addition to those resulting from the consequences of purchased power.

${ }^{90}$ As an example, it is pointed out that San Diego Gas and Electric Company (SDG\&E) would have to incur an expenditure of $\$ 2.7$ billion in case it were to buy its $1,375-\mathrm{MW}$ purchased power share. On this outlay, SDG\&E would have to raise $\$ 2.1$ billion in new capital. The unresolved issue is how the rating agencies would view this development. See Daniel Scotto, "Build Versus Buy: You Can Run but You Can't Hide," Public Utilities Fortnightly (September 15, 1992), pp. 14-17.

${ }^{91}$ Virginia Power is the commonly used name for Virginia Electric Power Co.

${ }^{42}$ Virginia Power's bid evaluations include dispatchability, location of the owner, transmission and distribution capability, fuel type, and project viability. As a result of the modifications adopted by Virginia Power, provisions exist for declining acceptance of uneconomical power and rejecting providers who do not meet certain availability standards in exchange for minimum capacity payments.

${ }^{93}$ Based on a conversation with officials of Virginia Power and the State Corporation Commission of the Commonwealth of Virginia in June 1993.

${ }^{94}$ Virginia Power's rating was downgraded from A+ to A in 1991 by S\&P.

${ }^{95}$ Based on comments submitted by the National Independent Energy Producers (NIEP) on April 20, 1993, to the Commission Investigation regarding EPACT of 1992, Case No. PUE93C, to the State Corporation Commission, Richmond, VA.
} 
this should preclude any significant impact on the purchasing utility's cost of capital.

The IPPs point out that by their participation in power production, they have introduced a new class of competitive discipline in the generation of electric power that can only bring benefits to consumers. In the process, the IPPs indicate that they have assumed responsibility in areas which caused problems for the utilities in the past and imply that, by taking them over, the risks to a utility are lowered. The IPPs conclude that when all factors are taken into account, power purchase contracts impose less risk on a utility's creditworthiness than would a self-construction activity.

\section{The Purchasing Utilities' Views}

Most utilities that rely on purchased power generally seem to agree with the rating agencies' views that purchased power (in excess of a given level, usually 10 percent or more) does affect their bond-rating adversely. This leads to a reduction in the financial flexibility of the utility, and the increased costs of borrowing have a counterpart in rate increases for the customers.

Suggested corrective actions to avoid a downgrade are either to lower business risk or raise financial protection. Both these options have logistical difficulties. Variables designed to lower the business risk lie outside the control of the utilities. ${ }^{96}$ Raising financial protection generally amounts to changes in capitalization by raising the level of equity or permitting a higher (than before) rate of return on equity so that the interest coverage ratio remains unaltered. Raising equity will itself result in raising the cost of capital. Raising rates of returns on equity may induce industrial customers to look at alternative sources of supply. In addition, there may be no incentive for the utility to secure the most economical contract. Thus, both these approaches are beset with practical difficulties.

Another variant of the financial improvement objective is to allow the utility to make a profit on such purchases instead of a pass through. ${ }^{97}$ However, some regulatory authorities feel that utilities may be less determined in their bargaining (for purchased power) to the detriment of rate payers. The probability of such a procedure being adopted is, therefore, moot at this time.

Utilities express concern with the market risk (implying that the power will not be needed or that it may not be economic) associated with unregulated generation projects in power purchase commitments. Recognizing that market risks exist even when utilities self-generate, the primary disincentive to undertaking new construction stems from the pursuance of cost minimization policies by the various regulatory authorities. It is suggested that these policies penalize the utilities. Permitting offsetting incentives (similar to those as in the implementation of demand-side management programs) may be helpful to the financial health of the utilities.

\section{The Regulatory Perspective}

State regulatory authorities recognize that power purchases may lower a utility's bond-rating but are reluctant to adopt any generic rules to counteract the consequences of purchased power contracts on a utility's cost of capital. It is argued that it is difficult to stipulate conditions that would take into account contingencies emerging in a changing environment. Accordingly, regulatory authorities would prefer to consider this aspect on a case-by-case basis as a part of the integrated resource planning process or as a part of the rate hearing process.

There exist operational difficulties which preclude the adoption of specific rules on the subject. Additions to capacity result in an increase in debt (at least in the short run) in the case of self-generation by a utility. Additional revenue requirements become necessary to support an addition to capacity. In such a case, the increment to revenue requirements can be easily estimated within the conventional ratemaking regulatory framework. The corresponding increase in imputed debt attributable to purchased power contracts is difficult to determine with precision. ${ }^{98}$ For this reason alone, any attempt to offset the imputed debt increase

\footnotetext{
${ }^{*}$ Included in this category are: constructive regulatory environment, enhancing monopoly power of the utility, and a growing economy.

${ }^{97}$ In some cases, the request for a rate increase is masked by recommending that power purchase capacity payments be included in the ratebase, permitting the utility to get a return commensurate with its cost of capital.

${ }^{98}$ Differences in methodologies of bond-rating agencies can lead to varying results. In the case of San Diego Gas and Electric Company (SDG\&E), the three agencies assigned the following 1992 debt equivalents to SDG\&E: Standard and Poor's-\$298 million, Duff and Phelps - $\$ 432$ million, and Moody's-\$1,214 million. Using these debt levels, SDG\&E's unadjusted interest coverage ratio of 4.3 drops to 3.6 using S\&P's adjustment, 2.6 using Moody's adjustment, and 3.4 using Duff and Phelps' adjustment. Refer to Prepared Testimony of Michael Grossblatt in proceedings before the California Public Utilities Commission (Application No. A.93-05-011) on the "1994 Cost of Capital."
} 
becomes conceptually difficult. Moreover, the risks of purchased power hinge on the nature of the contract between the utility and the nonutility generator. Power purchase contracts, therefore, need to be evaluated with care to assess where the risk resides. ${ }^{99}$

Nonutility generators maintain that refinements in the contracting process shift many of the risks away from the utilities and greatly minimize the adverse impact of power purchases on the cost of capital. Given the divergence of views and the uncertainties associated with remedial measures, there does not appear to be any unique regulatory solution to the problem of restoring a utility's bond-rating downgraded due to power purchase agreements.

In the meantime, the possibility that the bond-rating agencies may moderate their views on the comparative riskiness of the "buy/build" decision also has been voiced. More specifically, the notion to hold the obligations of contingent, executory power purchase contracts on par with fixed and irrevocable debt payment obligations may be reconsidered. ${ }^{100}$

\section{Leveraged EWGs and Reliability of Power Supply}

\section{The Cost of Capital Advantage}

Nonutility generators normally employ a non-recourse "project financing" mechanism to finance a new generating project. In this method, the assets of the project alone constitute the available collateral to secure the loan. Project cash flows are used for repayment and in most cases this is linked to the credit strength of the power purchaser. ${ }^{101}$ Thus, other corporate assets and earnings of the developer or the parent are excluded by virtue of the non-recourse arrangement.
The above project financing arrangement is based on debt constituting a large proportion of the aggregate financing requirements with little or no equity participation. ${ }^{102}$ As a result, one view is that the cost of capital to nonutilities is lower than the cost of capital that investor-owned utilities confront in their implementation of a decision to build. This capability to finance new construction projects with a highly leveraged capital structure with potential costs of capital lower than those enjoyed by the investor-owned segment could confer on the EWGs an unfair competitive advantage. ${ }^{103}$ Some among the private utility industry indicate that the EWGs should be required to maintain the same relative capital structure ratios as the investor-owned utilities do. Whether or not this requirement will make the cost of capital uniform to both the groups is not clear but the intent to provide a level playing field (with respect to the financing of assets used to produce electricity) would be met. ${ }^{104}$

Table 15 shows the difference in cost of capital between a typical utility and a typical IPP.

Investor-owned utilities maintain that EWGs or other nonutility generators enjoy the above advantage (i.e., the difference in cost of capital) because they are able to shift many of the project risks to the utilities. When a utility enters into a long-term wholesale power purchase contract, in most cases the contract is a performance contract. In other words, the utility is obligated to pay capacity charges even if the power is not needed but is available. The utility thus assumes the demand risk and the nonutility generators' fixed costs are covered by the contracting utility.

Nonutilities respond that computation of the weighted average cost of capital (WACC) is a static and inappropriate measure. The WACC fails to take into account the shorter debt terms secured by the IPPs and the more stringent lender-imposed requirements for

\footnotetext{
9The following are broad areas of risk under either a "build" or a "buy" strategy: construction risk (delays, cost overruns, or plant cancellations); regulatory risk (prudence reviews, phase-ins or other disallowances); operating risk (reliability issues); supply risk (nonavailability of power when needed); and demand risk (lack of demand leading to stranded investment or uneconomical power). In case of power purchases, the risk to the utility is a possible erosion of its rate base.

${ }^{100}$ Philip S. Cross, "Making the Grade: Credit Ratings and Purchased Power," Public Utility Fortnightly (February 15, 1993), pp. 49-52.

${ }^{101}$ For additional information on this aspect, see Standard and Poor's CreditWeek (October 12, 1992).

${ }^{102}$ The percentage of total project cost (of a sample of 11 projects) provided by equity ranged from 7 percent to 25 percent. See Edward Kahn et al., Analysis of Debt Leveraging in Private Power Projects (Berkeley, CA: Lawrence Berkeley Laboratory, August 1992).

${ }^{103}$ The proportion of debt in IPP or EWG financing may range from 75 to 100 percent. Investor-owned utilities, as indicated in Chapter 2 , are required to maintain a debt equity ratio of 1 or less than 1 , implying that they should preferably have no more than 50 percent debt in the capitalization.

${ }^{104}$ Proceedings at the Public Utilities Commission of Ohio, "In the Matter of the Commission's Investigation of Section 712 of the Energy Policy Act of 1992," Case No. 93-898-EL-COI (July 1993).
} 
Table 15. A Simplified Example of Differences in Capital Costs

\begin{tabular}{|c|c|c|}
\hline Assumptions & $\begin{array}{l}\text { Investor- } \\
\text { Owned } \\
\text { Utility } \\
\text { Project } \\
\text { (Percent) }\end{array}$ & $\begin{array}{c}\text { Nonutllity } \\
\text { Generating } \\
\text { Project } \\
\text { (Percent) }\end{array}$ \\
\hline Debt & 50 & 90 \\
\hline Equity & 50 & 10 \\
\hline Interest Rate $\ldots \ldots \ldots \ldots$ & 10 & 12 \\
\hline Return on Equity . . . . . . . & 12 & 15 \\
\hline Tax Rate $\ldots \ldots \ldots \ldots$ & 40 & 40 \\
\hline $\begin{array}{l}\text { Weighted Average After-Tax } \\
\text { Cost of Capital }{ }^{\mathrm{a}} \ldots \ldots \ldots\end{array}$ & 9.00 & 7.98 \\
\hline
\end{tabular}

a Weighted Average After-Tax Cost of Capital $=[($ Debt $\times$ Interest Rate) (1 - Tax Rate)] + [Equity $x$ return on Equity].

Notes: (i) All values are assumed, typical values for illustrative purposes. (ii) The difference between the two rates becomes more pronounced it the tax implications of equity payments are taken into account. In each category, the pre-tax income would have to be $\$ 1.67$ to support a payment of $\$ 1.00$ in equity. Note also that both the cost of debt and equity are assumed to be higher for the nonutility segment. The tax deductibility of debt lowers the cost significantly for the IPPs/NUGs. (iii) In a similar presentation, the National Independent Energy Producers (NIEP) claim that the IPPs' cost of capital is higher. See NIEP, The Reliability of Independent Power (Washington, DC, September 1991).

Source: Energy Information Administration, Office of Coal, Nuclear, Electric and Alternate Fuels.

such loans. Both these factors tend to raise the IPP's cost of capital. ${ }^{105} \mathrm{~A}$ shorter debt life implies that the debt component declines rapidly, so that after the first 8 or 9 years debt levels in nonutility generating projects are invariably lower than the uniformly maintained debt level (approximating nearly 50 percent) in a typical utility's capitalization. Thus, the utility enjoys more advantages than a nonutility due to the modalities of debt financing. Variations in financing methods can actually raise the overall cost of capital for the nonutility even more. Based on these considerations, the nonutility industry group maintains that costs of capital vary among projects with no clear advantage for either group. ${ }^{106}$
Practitioners of finance theory examine this issue with a different perspective. The capital structure problem is viewed as a problem in optimization where the optimum capital structure is one that maximizes the value of the firm or minimizes its cost of capital (consisting of debt and equity). The inquiry, with respect to what the optimal capital structure is, leads to the conclusion that the cost of capital does not necessarily decline as the proportion of debt increases. It is pointed out that the tax deductibility of interest payments on debt initially lowers the cost of capital; however, the cost of capital may be the same when the tax advantage is neutralized by lower equity costs, or may be higher when other financial considerations of risk overtake the tax-deductibility advantage. Based on these considerations, the cost of capital is shown to possess a saucer-shaped curve (Figure 11). Since the nonutilities operate at points located to the extreme right of this curve, they are unlikely to have a cost of capital advantage over the investor-owned utilities. A recent study dealing with these observations finds the capital structure of the two groups to be competitively neutral. ${ }^{107}$

\section{Figure 11. Hypothetical Cost of Capital Curve with Differing Proportions of Debt}

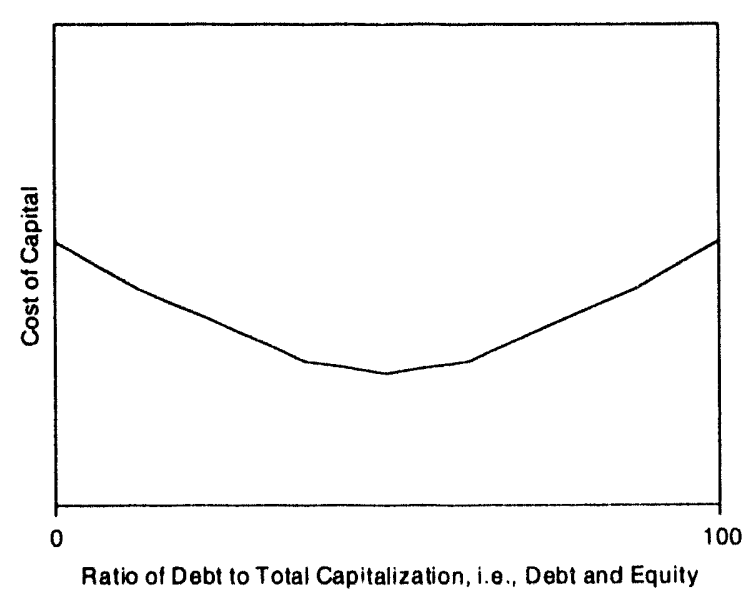

Source: Energy Information Administration, Office of Coal, Nuclear, Electric and Alternate Fuels.

\footnotetext{
${ }^{105}$ See Roger F. Naill and William C. Dudley, "IPP Leveraged Financing: Unfair Advantage?" Public Utilities Fortnightly (January 15, 1992), pp. 15-18. Utilities generally issue debts with maturities ranging from 30 to 35 years. The IPPs' debt maturity range is 12 to 15 years. In addition, IPPs are often required to maintain cash reserves, which reduce the availability of potential returns on equity in the earlier years of the project. These authors point out that the capital charge rate is a better indicator than the WACC and show (in the example they present) that the capital charge rate of the IPPs is about 4 percent higher than those of the utilities.

${ }^{106}$ Based on the comments submitted by the National Independent Energy Producers (NIEP) to the "Commission Investigation Regarding Energy Policy Act of 1992, Case No. PUE390" of the State Corporation Commission of the Commonwealth of Virginia on April $20,1993$. The NIEP filed similar comments in proceedings in other States with respect to Section 712 proceedings.

${ }^{107}$ Edward H. Jennings, "Financial Leverage and the Energy Policy Act of 1992," Electricity Journal (July 1993), pp. 52-61. Figure 11 is adopted from this article.
} 


\section{The Reliability Issue}

Apart from the unfair capital cost advantage claim, there is also a concern with reliability, i.e., operational reliability and the probability of default. Reliability could be threatened if the nonutility generator fails to perform maintenance as required due to financial or other problems. Low levels of equity participation make it easier for the nonutility developer to abandon any project in the face of financial difficulties. As a result, defaults could occur. Foreclosure is viewed as another possibility in this context.

The nonutility industry group maintains that the nature of project financing fosters a strong discipline to ensure reliability. Each project is intensively scrutinized at various levels for its technical feasibility to operate as planned. Purchasing utilities also monitor various aspects of a project's operation to ensure performance as contracted.

In the absence of performance as per the contract, a nonutility generator stands to lose its cash flow and would incur problems in meeting its obligations to its lenders. As a result, there is a strong incentive for nonutilities to perform and maintain reliability. Various contractual obligations with the utility, equipment and fuel suppliers, and debt holders reinforce compliance within strictly defined narrow bounds.

\section{Reliability and Leverage}

Conceptually, it is difficult to establish a linkage between operational reliability and the leverage element of a nonutility, "just as there is no connection between the amount of debt on a utility's balance sheet and the operating efficiency of its operating units." ${ }^{108}$ The operational record of nonutilities in various States does not support the concern with respect to reliability: "Studies of independent power production in Texas, upstate New York, Maine, New Hampshire, and Virginia 'ndicate that IPPs are reliable, exceed utility availability factors or exceed expectations for operational reliability." 109
The aspect of reliability was really a non-issue at the recent Section 712 EPACT proceedings in jurisdictions across the country. However, the default aspect was discussed at some length on grounds of the highly leveraged structure of nonutility projects. To a great extent, default could be a possibility due to narrow margins over debt service and operating costs. To counter this possibility (and its potential impact on power supply), contract provisions could be framed so as to insulate a utility from the consequences of default. Suggested cont:act provisions include high liquidated damage clauses, guarantees of backup power, stipulation of monetary guarantees (or even the creation of a reserve fund) for failure to perform, and default provisions to transfer control of the facility to the utility. Various other non-contractual provisions, such as investigating the developers' record, are also indicated. Overall, the regulatory viewpoint seems to be that welldefined contracts should succeed in ensuring reliability and in containing defaults. No specific regulatory standards for the nonutilities were accordingly recommended for adoption.

\section{Pre-Approval of Long-Term Wholesale Power Purchase Contracts}

The third Section 712 standard is concerned with the issue of pre-approval of wholesale long-term purchase contracts between the utilities and EWGs. Many nonutility generators support the concept of pre-approval of long-term wholesale power purchase contracts on grounds that it would significantly reduce regulatory risk associated with power purchase contracts. This, in turn, may lower the costs for the power producers, the utilities, and their ratepayers. The motivation for making this argument is that the adoption of the preapproval process would preclude the inclusion of "regulatory out" clauses (by the utilities) in power purchase agreements. ${ }^{110}$

Many utilities also support pre-approval on the ground that concerns of the regulatory authorities could be addressed before any commitment-is made. In some quarters, the need for pre-approval is conditioned by a

\footnotetext{
${ }^{106}$ Iowa Utilities Board, Department of Commerce, "Report of the Board of Enquiry into Title VII of the Energy Policy Act of 1992," Docket No. NOI-93-1 (May 1993), p. 37.

${ }^{109}$ See report of the Coalition of Non-Utility Generators (prepared by Economics Resource Group) entitled "Competition in Electricity Generation: The Risks and Merits of Independent Power Production in Massachusetts" (Cambridge, MA, June 1993), pp. 29-30.

${ }^{110} \mathrm{~A}$ "regulatory out" clause in a power purchase agreement relieves the utility from some or all contract payments if the State regulatory authorities do not allow recovery of that payment from the ratepayers. The inclusion of this clause adds to the uncertainty facing an independent power producer, i.e., raises its risk as viewed by the lenders. This increased risk is reflected in the borrowing costs. For an additional discussion on this subject, see National Independent Energy Producers, Negotiating Risk: Efficiency and Risk Sharing in Electric Power Markets (Washington, DC, September 1992), pp. 15-18.
} 
request for streamlining the process to eliminate delays that regulatory reviews might possibly cause.

The regulatory authorities generally seem reluctant to accede to the pre-approval process primarily because the operational problems associated with it are substantial. In a pre-approval process, once costs related to the power purchase agreements are approved, they would continue to be recovered even if the contract subsequently becomes uneconomical. The risk in such cases inevitably would be shifted to the ratepayers, and this burden may not be acceptable.

In view of these considerations, regulatory authorities currently prefer not to implement procedures for the advance approval or disapproval of a long-term power purchase contract, leaving it to the utilities to negotiate contracts on most favorable terms. This offers State regulatory authorities the flexibility to review contracts either during integrated resource planning or the leastcost planning process on a case-by-case basis. ${ }^{111}$ Within this framework, a continuing monitoring of the costs is thus made possible instead of a one-time decision implicit in the pre-approval process.

In States where integrated resource plarining or leastcost planning procedures are not yet formally in place, monitoring of the overall costs of purchased power contracts is taken into account whenever a utility requests a rate increase Thus, unreasonable or imprudent costs of a power purchase contract can be denied when considered appropriate.

\section{Assurance of Fuel Supply Adequacy}

Fuel costs are a critical ingredient of power production costs and changes in fuel costs can lower or raise the costs of delivered power. ${ }^{112}$ The fourth and final Section 712 standard draws attention to this issue and requires the State regulatory authorities to consider whether to require as a condition for the approval of long-term power purchases from the nonutilities, that there be reasonable assurance of fuel supply adequacy.

There is no easy rule that determines a utility's system fuel choices. The shape of the load to be served and the availability of resources are primary considerations. A multitude of other factors that include technical, economic and environmental considerations govern fuel choice determinations. Taking all these factors into account, system fuel choices aim to achieve a diverse mix that ensures reliability at life-cycle costs that are reasonably eronomic. Within this configuration, other attributes like transmission and distribution and surrounding utilities are critical influences.

Contracting for long-term fuel supply is, however, complicated. Coal, for example, is the dominant fuel used in domestic power generation. There are at least six basic contract types for coal supply for which data are collected. ${ }^{113}$ These contracts may be either shortterm or long-term. ${ }^{114}$ Contract coal, regardless of its availability, has to be transported an average of 437 miles before it can be converted into electric power. ${ }^{115}$ This implies that assurance of adequate supply of coal requires at least two contracts-one for the resource and another for transportation-that the utilities have to negotiate and finalize. Most utilities do not enter into coal contracts that coincide with the 40-year typical life of a coal plant. Yet, the adequacy of coal supplies has not been a constraint in the operation of the investorowned plants.

The point is that contractual terms are determined in the market and are based on considerations of demand and supply. In some cases, where utility operators contracted on a long-term basis to secure fuel supplies at pre-determined prices, the consequences did not always represent the preferred or the desired economic solution. For example, during the late 1970s, it appeared to many that shortages of uranium fuel would occur. Uranium prices rose beyond their economic levels with suppliers and consumers (i.e., nuclear

\footnotetext{
"11'As indicated earlier, provisions of EPACT Section 111 contain three efficiency standards that amend PURPA Section 111. Of these, the first standard requires consideration of integrated resource planning. This will require a utility to include in its submission (to the State regulatory authority) all supply and demand-side options that minimize its system cost.

${ }^{112}$ Currently, fuel costs account for nearly 20 percent of power generation costs. For further details, see Energy Information Administration, Annual Energy Outlook 1994, DOE/EIA-0383(94) (Washington, DC, January 1994), p. 65.

${ }^{113}$ For a description of coal contract types, see Federal Energy Regulatory Commission, (FERC) Form 580, "Interrogatory on Fuel and Energy Purchase Practices" used in collecting coal data on quality and origin of coal purchased under contract by selected utility plants, and the carriers, modes and other items.

${ }^{114}$ Long-term contracts can range from 3 to 30 years in duration. One version of a long-term contract is the "requirement contract" where a buyer purchases all his coal from a single seller. Developments in unit trains and transmission supported this trend in the past. See Federal Trade Commission, Concentration Levels and Trends in the Energy Sector (Washington, DC, March 1974), p. 82.

${ }^{115}$ Energy Information Administration, Trends in Contract Coal Transportation 1979-1987, DOE/EIA-0549 (Washington, DC, July 1991), p. ix.
} 
plant owners) entering into long-term contracts (at fixed prices with escalation clauses built in). However, when the anticipated demand for electricity lagged and eliminated the need for nuclear capacity additions, nuclear plant cancellations could not be avoided. ${ }^{116}$ In such cases, suppliers and /or buyers with long-term contracts for uranium had a difficult time sorting out the resulting liability problems. In other cases (where nuclear plants were actually built), utilities had no option but to buy uranium at contracted prices that were significantly higher than the prevailing market prices.

This situation transpired under market conditions. In another case, the Power Plant and Industrial Fuel Use Act of 1978 imposed restrictions on the utilization of natural gas and oil. New plants using natural gas could not be constructed, and existing gas fired plants were expected to be gradually phased out. ${ }^{117}$ These constraints have since been removed, and natural gas can again be used for power generation. ${ }^{118}$ In the meantime, many long-term natural gas contracts had to be canceled. These changes point to the unanticipated consequences of long-term fuel contracting.

The experience of the investor-owned utilities in the area of fuel acquisition is also applicable to nonutility generators. When a nonutility submits a contract, its various provisions are closely scrutinized by the utility, lenders, and others. Fuel adequacy is one of the critical provisions and is incorporated in the "request for proposal" stage. ${ }^{119}$ In addition, performance requirements are difficult to meet unless continuity in operations (contingent on fuel availability) can be maintained. The developers of the project (who assume the risk for fuel supply) have a strong incentive to eliminate the key operating risk, i.e., the adequacy and availability of fuel.
For the reasons stated above, the nonutility industry group did not favor the adoption of the standard to require the assurance of fuel supply adequacy as a condition for the approval of proposed long-term power purchase agreements. It is submitted that the fuel supply adequacy should not be "equated with absolute long-term fuel supply and transportation contracts. ${ }^{120}$ Insistence on securing a long-term fuel contract may be tied to unreasonable escalators or may be available only on a cost-plus basis. The market approach results in flexibility and in lower fuel costs.

Utilities that support the adoption of this standard do so in the hope of eliminating prudence review disallowances at a later stage. A majority, however, maintain that any power purchase agreement should establish reasonable, adequate, minimum levels of fuel security assurances. The levels of fuel adequacy assurance should also be viewed as a function of the load characteristic that a nonutility plant is expected to serve. $^{121}$

Most State regulatory authorities did not recommend adopting any standards for fuel adequacy, noting that formulation of generic standards in the abstract is not desirable and that reviews associated with either integrated resource planning or least-cost planning offer the regulators a better opportunity to examine issues in a timely fashion and on a continuing basis.

\section{Summary of Regulatory Response to Section 712 Standards}

Most State commissions have completed their evaluations of the Section 712 standards as mandated in the Energy Policy Act of 1992. The overwhelming

\footnotetext{
${ }^{116}$ For further details, see Energy Information Administration, Nuclear Plant Cancellations: Causes, Costs and Consequences, DOE/EIA-0392 (Washington, DC, April 1983).

${ }^{117}$ Energy Information Administration, Analysis of Proposed U.S. Department of Energy Regulations Implementing the Power Plant and Industrial Fuel Use Act, DOE/EIA-0102/21 (Washington, DC, November 1978).

${ }^{118}$ In its rulemaking to consider the Commission compliance with the Energy Policy Act of 1992, the Public Utilities Commission of the State of California (Decision 93-11-068) observed that if "we can be so wrong about a conventional fuel, then there is even more reason to doubt our ability to accurately assess new generation technologies or alternative fuels. Then implementing this EPACT standard could stifle innovation and jeopardize the long-term energy security that innovation might enhance."

${ }^{119}$ An examination of the "Request for Proposal for Power Purchases-1989 Solicitation" document developed by Virginia Power and North Carolina Power details specifics with respect to fuel and fuel diversity, requirements of fuel storage at site (depending on fuel type), and price. In addition, the document states that the utility favors "projects using fuel with stable prices and assured supplies." These considerations account for 10 percent of the weight in the utility's evaluation process.

${ }^{120} \mathrm{Comments} \mathrm{by} \mathrm{National} \mathrm{Independent} \mathrm{Energy} \mathrm{Producers} \mathrm{On} \mathrm{Commission} \mathrm{Investigation} \mathrm{Regarding} \mathrm{Energy} \mathrm{Policy} \mathrm{Act} \mathrm{of} \mathrm{1992,} \mathrm{Case} \mathrm{No.}$ PUE930, to the State Corporation Commission, Commonwealth of Virginia, Richmond, VA, on April $20,1993$.

${ }^{121}$ In its filing in Case U-10337 (The Michigan State Public Service Commission's Own Motion to Examine Issues Regarding Power Purchases By Electric Utilities for EWGs as Enumerated in Sec. 712 of the Energy Policy Act of 1992), Consumers Power provided a copy of its standard fuel security provisions developed for baseload power plants. These provisions are comprehensive and stipulate penalties where a nonutility generator fails to provide adequate assurance with respect to fuel supplies.
} 
regulatory view is not to adopt generic standards on any of the four issues discussed above but rather to retain the flexibility to address them on a case-by-case basis. The vehicles available to the State regulatory authorities for so doing lie within the scope of integrated resource planning or least-cost planning proceedings or the rate case hearings.

The primary reason for rejecting Section 712 standards stems from the difficulty in establishing standards that would encompass all current and future problems of the long-term power purchase contracts. This is especially true where the issues involved are still being debated and remain unresolved or where the evolutionary process is still in its early stages. Regulators are also reluctant to actively participate in a management or a decision-making role and prescribe options that should hold good for the next 30 to 40 years (i.e., the life of some of the power plants).

It is argued that the contracting parties (i.e., the utilities and the nonutility generators) have adequate incentives to protect their economic interests. It makes more sense (from a regulatory perspective) to be able to review and assess what has been done and suggest remedial corrective actions rather than participate and prescribe at every stage of the process. This line of proposed action inhibits the transfer of risks to the ratepayers implicit in regulatory decisions.

Table 16 presents a summary of the State commission determinations. Findings and orders on Section 712 proceedings by State regulatory authorities can be broadly classified in the following categories:

- Adopt the standard(s)

- Decline to adopt the standard(s)

- Existing regulatory framework in the State will be used to take Section 712 standards into account on a case-by-case basis or the framework will be expanded to permit such a consideration in the future

- No action at present. Issues may be re-examined at a later date

- Final order yet to be issued.

In attempting to design the above classification scheme, the intent is to keep it simple and manageable. In the process, some details are inevitably sacrificed. As an example, the category "decline to adopt the standards" does not fully explain the factors behind the regulatory decision by State regulatory authorities. It could be that adoption of Section 712 standards does little to promote the purposes of Title I of the PURPA legislation. In other cases, there may have been a general ambivalence in adopting generic standards that could constrain regulatory initiatives on a continuing basis.

\section{Impacts of Section 712 on the Industry}

Even though most State regulatory authorities rejected adopting generic standards with respect to the purchase of long-term wholesale power, the relevance of Section 712 standards lies in drawing attention to various issues that ensue from power purchase contracts. The full range of impacts of prevailing and future power purchases on the utilities and the ratepayers is still unfolding. However, the concerns now raised will receive due scrutiny to safeguard the interests of utilities, nonutility generators, and ratepayers.

The eventual impact of EPACT on electric utilities will depend on the totality of its provisions of which Section 712 standards are only a part. Contemplated changes will accelerate the pace of competition in electricity markets. The extent to which the vertically integrated utility structure undergoes a fundamental change remains to be seen.

Financial market analysts take the view that the utilities may absorb more risk as a result of power purchases and grow less (in terms of adding to the asset base) in the future. ${ }^{122}$ With a declining asset base and with the possibility that some large industrial customers may gain direct access to nonutility power producers, total industry revenues may also decline. In the face of a continuing $\epsilon$ rosion of the asset base, some analysts do not envision a bright future for the utilities in general.

These fears may be unfounded as utilities prepare to meet the challenges of the future by augmenting investments in transmission and distribution infrastructure. Productivity increases that trim the overall cost of providing service will receive considerable attention in an effort to remain competitive and avoid the loss of industrial customers. Other attempts to remain competitive include permitting large industrial customers special rates so that the inducement to secure supplies

\footnotetext{
${ }^{122}$ Speech delivered by Howard Hiller, Salomon Brothers Inc., at the conference of the National Association of Regulatory Commissioners on November 15, 1993. Similar views have been expressed by other rating agencies.
} 
Table 16. Summary of State Commission Determinations Regarding Section 712 Standards of the Energy Policy Act of 1992

\begin{tabular}{|c|c|c|c|c|c|}
\hline \multirow[b]{2}{*}{ State } & \multirow[b]{2}{*}{ Docket No_Case No. } & \multicolumn{4}{|c|}{ Status Regarding Standards For } \\
\hline & & $\begin{array}{c}\text { Impact of } \\
\text { Long-Term } \\
\text { Power Purchase } \\
\text { Contracts on } \\
\text { Utility Cost of } \\
\text { Capital }\end{array}$ & $\begin{array}{c}\text { Effects of } \\
\text { Leveraged } \\
\text { Capital Structure } \\
\text { on Reliability of } \\
\text { Wholesale Power } \\
\text { Sellers }\end{array}$ & $\begin{array}{l}\text { Whether } \\
\text { to Grant } \\
\text { Pre-Approval of } \\
\text { Long-Term } \\
\text { Power Purchase } \\
\text { Contracts }\end{array}$ & $\begin{array}{l}\text { Whether } \\
\text { to Require } \\
\text { Assurance of } \\
\text { Fuel Supply in } \\
\text { Power Purchase } \\
\text { Contracts }\end{array}$ \\
\hline $\begin{array}{l}\text { Alabama } \\
\text { Alaska } \\
\text { Arizona } \\
\text { Arkansas } \\
\text { California } \\
\text { Colorado } \\
\text { Connecticut } \\
\text { Delaware } \\
\text { District of Columbia } \\
\text { Florida } \\
\text { Georaia } \\
\text { Hawall } \\
\text { Idaho } \\
\text { Ilinois } \\
\text { Indiana } \\
\text { lowa } \\
\text { Kansas } \\
\text { Kentucky } \\
\text { Louisiana } \\
\text { Maine } \\
\text { Marvland } \\
\text { Massachusetts } \\
\text { Michiaan } \\
\text { Minnesola } \\
\text { Mlssissipol } \\
\text { Mlssour } \\
\text { Montana } \\
\text { Nebraska } \\
\text { Nevada } \\
\text { New Hampshire } \\
\text { New Jersev } \\
\text { New Mexico } \\
\text { New York } \\
\text { North Carolina } \\
\text { North Dakota } \\
\text { Ohio } \\
\text { Oklahoma } \\
\text { Oregon } \\
\text { Pennsvivania } \\
\text { Rhode Isiand } \\
\text { South Carolina } \\
\text { South Dakota } \\
\text { Tennesseed } \\
\text { Texas } \\
\text { Utah } \\
\text { Vermont } \\
\text { Virainia } \\
\text { Washington } \\
\text { West Virainia } \\
\text { Wisconsin } \\
\text { Wyoming }\end{array}$ & 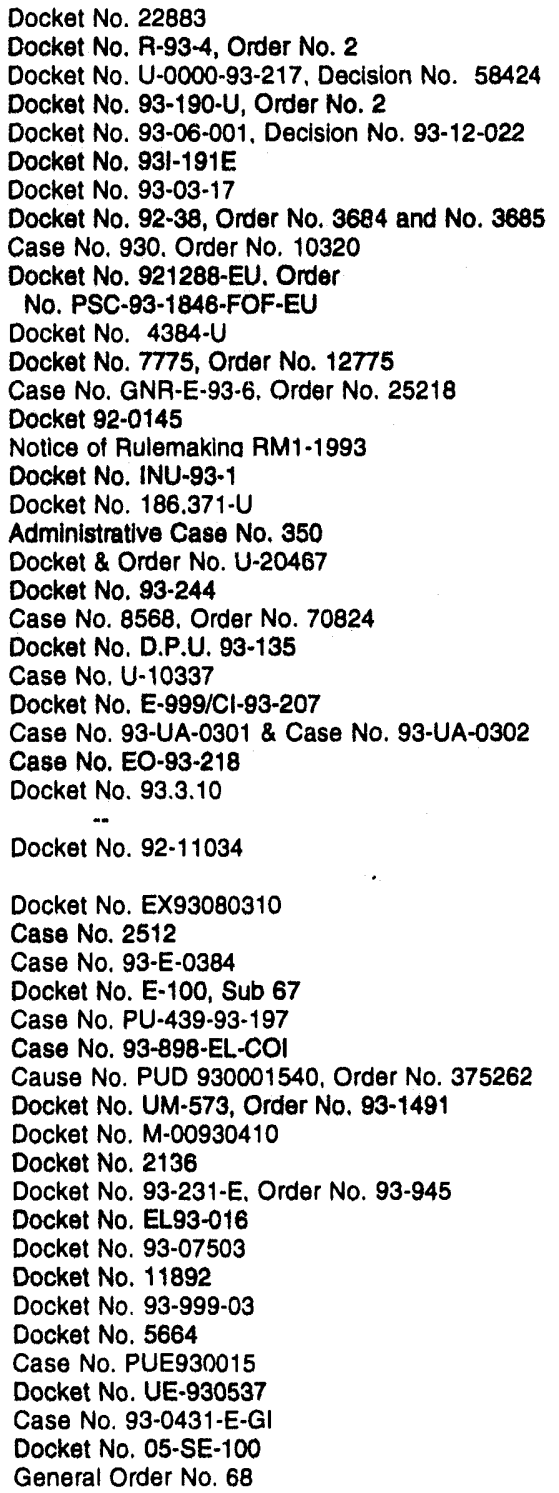 & $\begin{array}{c}E \\
D \\
C . D \\
D \\
D \\
C \\
C \\
D \\
C \\
C \\
C \\
C \\
A \\
C \\
P \\
C \\
D \\
C . D \\
C \\
C . D \\
P \\
C \\
C \\
E \\
C \\
C \\
C \\
C \\
P \\
\text { NA } \\
C \\
P \\
P \\
C \\
P \\
C \\
C \\
C \\
C \\
C \\
C \\
C \\
C \\
C \\
C \\
C \\
D \\
C \\
C \\
C \\
C \\
C \\
C \\
C\end{array}$ & 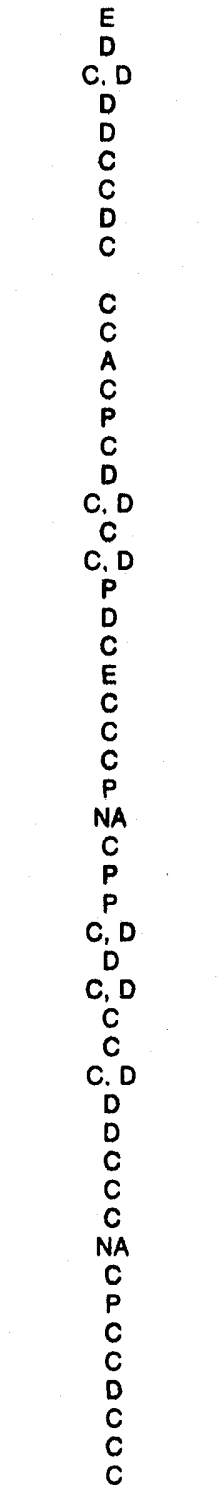 & 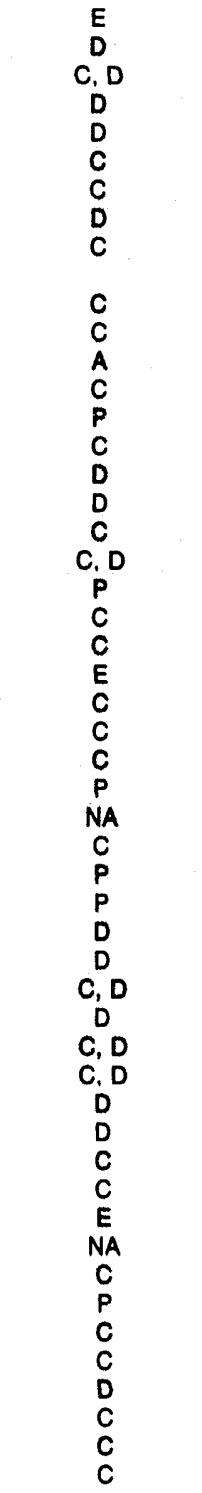 & 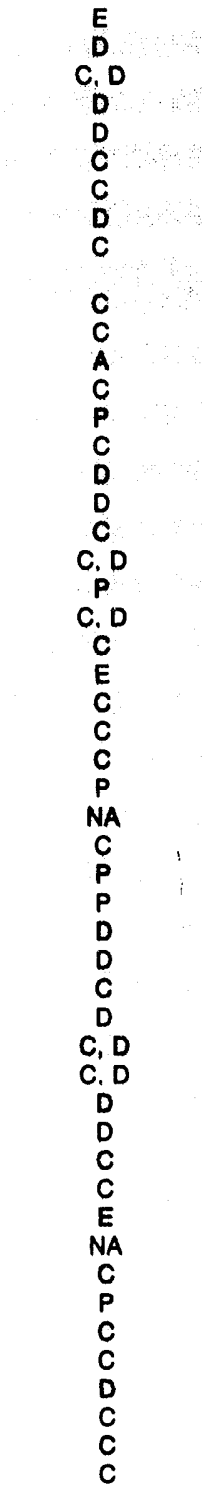 \\
\hline
\end{tabular}

$\mathrm{A}=$ Adopt the standard; $\mathrm{C}=$ Existing regulatory framework in the State will be used to take Section 712 standards into account on a case-by-case basis or the tramework will be expanded to permit such a consideration in the future; $D=$ Decline to adopt the standard; $E=$ No action at present. Issue to be re-examined at a later date; $P=$ Final order is pending; $N A=$ Not applicable.

bebraska has no Investor-Owned Utilities. All of its power is supplied by public utilities. There is therefore no government ratemaking function, making an evaluation unnecessary.

'The New Hampshira Public Utilities Commission is involved in ongoing litigation concerning their authority to seek certain information to further their Section 712 analysis. This has delayed the completion of the evaluation process.

'The Tennessee Public Service Commission feels that the Section 712 standards are inapplicable to the Commission, since the only electric company in the State, Kingsport Power Company, owns no generating facilities. It buys all of its power from Appalachian Power Company at rates which are determined by the Federal Energy Regulatory Commission.

Source: Information provided by State regulatory authorities. 
from nonutility generators is minimized. Renegotiation of uneconomic power purchase contracts will also become common. In addition, mergers and acquisitions among utilities may become more frequent than in the past. Finally, diversification could also be considered an additional option.

\section{Conclusions}

The primary objective of this report was to evaluate the impact of nonutility power purchases on the utility cost of capital. The two analytical approaches used in this report do not find that the utility cost of capital increases due to power purchases from nonutility generators. The evidence from the traditional financial analysis is inconclusive; that from the empirical approach indicates that the cost of capital increases more when the utilities undertake construction of new power plants instead of buying power. In addition, the empirical analysis failed to provide any evidence to support the debt-equivalence hypothesis.

The conclusions should not be construed as implying any degree of finality. As indicated, the full impact of the changes to be introduced by the EPACT has yet to unfold. The anticipated increase in competition in the electricity trade is designed to be phased in by conditions in the market rather than by regulation. Within this environment, the reluctance of the State regulatory authorities to adopt the Section 712 standards is understandable. 
Appendix A

Section 712 of the Energy Policy Act of 1992 


\section{Section 712 of the Energy Policy Act of 1992}

106 STAT. 2910

PUBLIC LAW 102-486-OCT. 24, 1992

SEC. 712. STATE CONSIDERATION OF THE EFFECTS OF POWER PURCHASES ON UTILITY COST OF CAPITAL; CONSIDERATION OF THE EFFECTS OF LEVERAGED CAPITAL STRUCTURES ON THE RELIABILITY OF WHOLESALE POWER SELLERS; AND CONSIDERATION OF ADEQUATE FUEL SUPPLIES.

Section 111 of the Public Utility Regulatory Policies Act of 1978 (16 U.S.C. 2601 and following)

16 USC 2621. is amended by inserting the following new paragraph after paragraph (9):

"(10) CONSIDERATION OF THE EFFECTS OF WHOLESALE POWER PURCHASES ON

UTILITY COST OF CAPITAL; EFFECTS OF LEVERAGED CAPITAL STRUCTURES ON THE RELIABILITY OF WHOLESALE POWER SELLERS; AND ASSURANCE OF ADEQUATE FUEL SUPPLIES.-(A) To the extent that a State regulatory authority requires or allows electric utilities for which it has ratemaking authority to consider the purchase of long-term wholesale power supplies as a means of meeting electric demand, such authority shall perform a general evaluation of:

"(i) the potential for increases or decreases in the costs of capital for such utilities, and any resulting increases or decreases in the retail rates paid by electric consumers, that may result from purchases of long-term wholesale power supplies in lieu of the construction of new generation facilities by such utilities;

"(ii) whether the use by exempt wholesale generators (as defined in section 32 of the Public Utility Holding Company Act of 1935) of capital structures which employ proportionally greater amounts of debt than the capital structures of such utilities threatens reliability or provides an unfair advantage for exempt wholesale generators over such utilities;

"(iii) whether to implement procedures for the advance approval or disapproval of the purchase of a particular long-term wholesale power supply; and

"(iv) whether to require as a condition for the approval of the purchase of power that there be reasonable assurances of fuel supply adequacy.

“(B) For purposes of implementing the provisions of this paragraph, any reference contained in this section to the date of enactment of the Public Utility Regulatory Policies Act of 1978 shall be deemed to be a reference to the date of enactment of this paragraph.

"(C) Notwithstanding any other provision of Federal law, nothing in this paragraph shall prevent a State regulatory authority from taking such action, including action with respect to the allowable capital structure of exempt wholesale generators, as such State regulatory authority may determine to be in the public interest as a result of performing evaluations under the standards of subparagraph (A).

“(D) Notwithstanding section 124 and paragraphs (1) and (2) of section 112(a), each State regulatory authority shall consider and make a determination concerning the standards of subparagraph (A) in accordance with the requirements of subsections (a) and (b) of this sertion, without regard to any proceedings commenced prior to the enactment of this paragraph.

"(E) Notwithstanding subsections (b) and (c) of section 112, each State regulatory authority shall consider and make a determination concerning whether it is appropriate to implement the standards set out in subparagraph (A) not later than one year after the date of enactment of this paragraph.". 
Appendix B

Listing of Two

Groups of InvestorOwned Utilities with

and without Significant Power Purchases from Nonutility Generators 


\section{Appendix B}

Table B1. List of Investor-Owned Utilities with Significant Power Purchases from Nonutility Generators

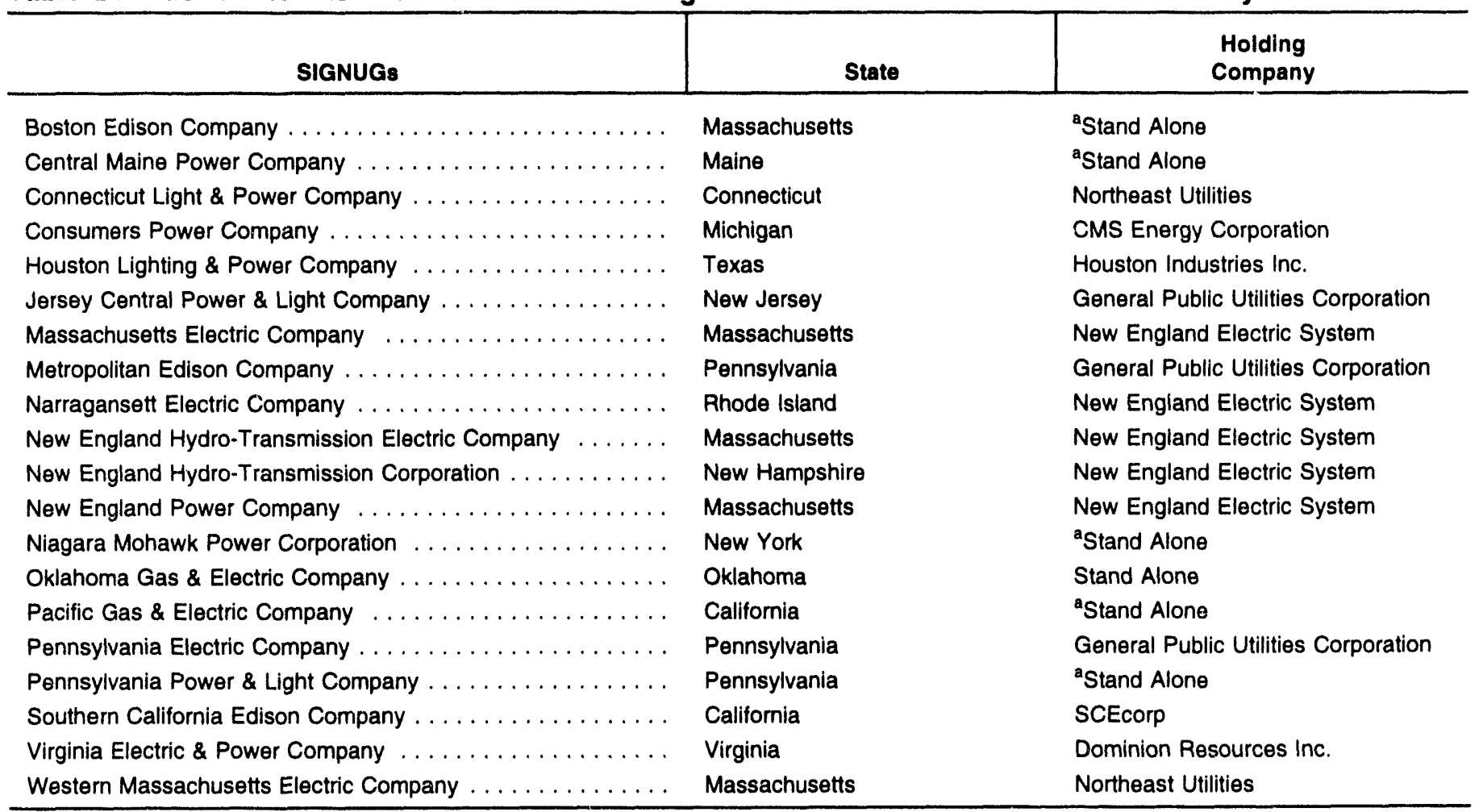

aStand Alone = no holding company.

Source: Energy Information Administration, Office of Coal, Nuclear, Electric, and Alternate Fuels. 
Table B2. List of Investor-Owned Utilities without Significant Power Purchases from Nonutility Generators

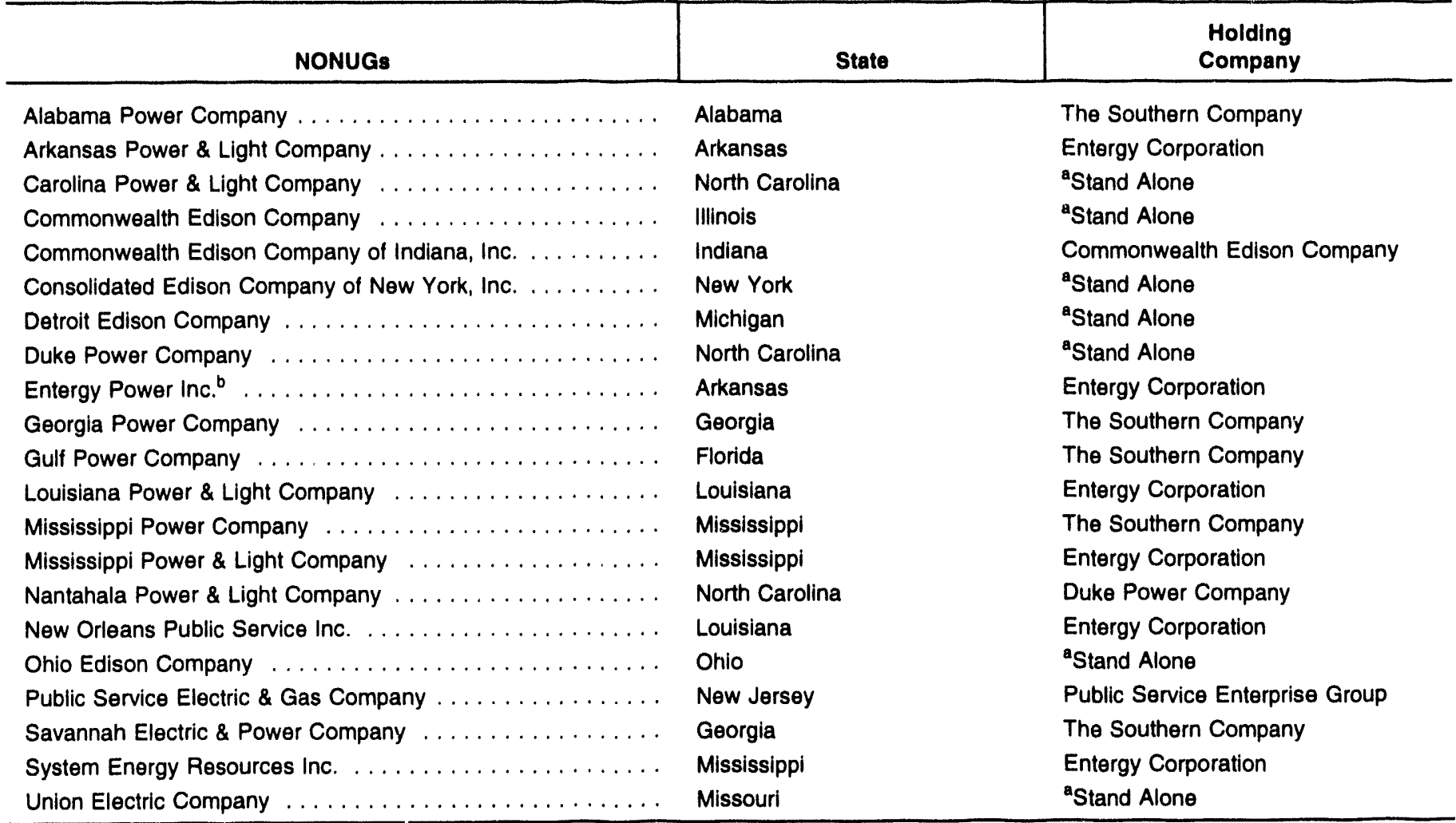

a Stand Alone = no holding company.

bEntergy Power is an independent power producer and is fully owned by Entergy Corporation, a holding company. The holding company owns four investor-owned utilities: Arkansas Power and Light, Louisiana Power and Light, Mississippi Power and Light, and New Orleans Public Service Inc. With a view to maintain consistency of data compilation with respect to Arkansas Power and Light, the financial data of Entergy Power Inc. have also been included. Recall that Entergy purchased the interests of two generating facilities initially owned by Arkansas Power and Light (100 percent interest in Ritchie 2 and 31.5 percent interest in Independence 2) in 1990.

Source: Energy Information Administration, Office of Coal, Nuclear, Electric, and Alternate Fuels. 
Appendix C

Cost of Equity

Capital Estimation:

Methodology,

Measurement Issues,

Data, and Regression Results 


\section{Appendix C}

\section{Cost of Equity Capital Estimation: Methodology, Measurement Issues, Data, and Regression Results}

\section{Methodology to Estimate the Cost of Equity Capital}

Chapter 3 provides summary results of the impacts of power purchases from nonutility generators on a utility's cost of equity capital. This Appendix provides details that include a discussion of the methodological approach, specification and measurement issues, data sources and regression results. ${ }^{123}$

\section{Cost of Equity Capital}

There is no generally accepted measure of the cost of equity capital, but only a number of competing theories that are more or less capable of being applied numerically. A brief survey of these theories indicates that at least three approaches are sufficiently quantitative that they can be used for empirical work. ${ }^{124}$ These are: (1) the discounted cash flow (DCF) method, (2) the earnings price ratio (EPR), and (3) the capital asset pricing model (CAPM). All of these methods rely primarily on stock market prices, but require additional data that must be estimated in particular cases as well. Each of these methods is reviewed below.

\section{Methods of Cost of Equity Capital Estimation}

\section{The Discounted Cash Flow Approach}

The discounted cash flow (DCF) method is an application of the standard present-value calculation to the market price of a utility stock, based on its expected dividends and their rate of growth. The formula for present-value calculations is given by the following expression:

$$
P V=\sum_{y=1}^{Y}\left[\frac{C F_{y}}{(1+r)^{y}}\right]
$$

where

$$
\begin{aligned}
\mathrm{CF}_{\mathrm{y}} & =\text { cash flow in year } \mathrm{y}, \\
\mathrm{PV} & =\text { present value, and } \\
\mathrm{r} & =\text { the discount rate. }
\end{aligned}
$$

The DCF model is based on the equivalence of the stock price, $P$, with the present-value of dividends, $D_{y^{\prime}}$ which are the cash flows in year $y$. The DCF model also requires two simplifying assumptions, namely: (1) that

\footnotetext{
${ }^{123}$ The results presented in this Appendix are based on the work performed at the Lawrence Berkeley Laboratory of the Department of Energy with funding provided by the Energy Information Administration, U.S. Department of Energy. Dr. Edward Kahn, the principal investigator, supported by Steven Soft and Timothy Belden, participated in the research and in providing the results. All tables in this Appendix were also prepared at the Lawrence Berkeley Laboratory.

${ }^{124} \mathrm{~L}$. Kolbe, J. Read, and G. Hall, The Cost of Capital: Estimating the Rate of Return for Public Utilities (Cambridge, MA: MIT Press, 1984), pp. 35-93.
} 
the discount rate $r$ remains constant in the future, and (2) that dividends are expected to grow at a constant rate, $g$, into the indefinite future (i.e., $Y$ in the presentvalue expression is infinite). Under these assumptions, the present-value definition of the stock price can be rewritten as:

$$
P_{0}=\sum_{1}^{\infty} \frac{D_{0} \cdot(1+g)^{y}}{(1+r)^{y}}=\frac{D_{0} \cdot(1+g)}{(r-g)}=\frac{D_{1}}{(r-g)} .
$$

Solving this equation for $r$, and reinterpreting it as the cost of equity capital, $r_{e}$, gives the standard form of the DCF model:

$$
r_{e}=\frac{D_{1}}{P_{0}}+g
$$

which says that the cost of equity capital is the sum of the expected dividend yield (paid at the end of period 1) divided by the stock price at the time of purchase (ex-dividend stock price at time 0 ) and the steady state expected growth rate of dividends in the future. Most of the difficulty associated with using the DCF model centers upon the estimation of the expected growth rate g.

The crucial step in the above argument is the reinterpretation of the stockholder's discount rate as the firm's cost of equity capital. To understand this, it should be noted that the firm must maintain the value of existing stock when issuing new stock. If it does not, it will find its ability to raise funds in the equity market seriously impaired (and eventually eliminated if it persists in devaluing its stock), and its costs in the bond market will increase. In order to maintain the value of existing stock, total stock value must increase by the amount of the funds raised by a sale of new stock. For this to occur, the firm must increase its stream of dividends by an amount with a present value equal to the new stock price. Thus, the cost of raising $\$ \mathrm{P}$ is a dividend stream with present value \$P when evaluated at the stockholder's discount rate, $r$. This dividend stream is exactly equal to the interest payments that would be made on $\$ \mathrm{P}$ borrowed at $\mathrm{r}$ percent; this justifies equating $\mathrm{r}$ with the firms' cost of equity capital.

\section{Earnings-Price Ratio Approach}

When using equation (1) to estimate the cost of equity capital, by far the greatest difficulty arises from the estimate of the expected growth rate of dividends, g. A literature review provides five methods for estimating $g \cdot{ }^{125}$ By adding a sixth, the methods for estimating the expected growth rate, i.e., $g$ are:

1. Historical growth rate of dividends

2. Historical growth rate of earnings

3. Historical growth rate of book value per share

4. Widely used forecasts of growth rates

5. Retained earnings to book value ratio

6. Retained earnings to market value ratio.

The first three estimates are not appropriate in evaluating the future cost of equity capital and how it may be changed by the future impact of new contracts. Available forecasts of dividend growth (from publicly available sources) per share will be used (in the fourth method) as an estimate ci $g$ for the DCF estimator in this work. The fifth method seems clearly inferior to the sixth because book value is simply market value distorted by various accounting conventions. The sixth method simply reduces to the well known earningsprice ratio method and will also be used. First, $g$ is replaced in the DCF equation with the ratio of retained earnings to market value, $R E / P$.

$$
r_{e}=\frac{D}{P}+\frac{R E}{P}=\frac{(D+R E)}{P} \text {. }
$$

Then, since dividends plus retained earnings add to total earnings, $E$, the basic DCF formulation reduces to what is called the earnings-to-price ratio method or the EPR:

$$
r_{e}=E / P \text {. }
$$

This estimator of $r_{e}$ depends on the assumption that a firm can earn only its cost of equity capital, no more and no less. If the firm can earn more than the cost of equity capital, then the growth rate expected from a given level of earnings is greater, and thus $g>R E / P$. Carrying this inequality through the derivation yields $r_{e}>E / P$. The converse applies if the firm earns less than the cost of equity capital. This point will require further consideration since the change in the cost of equity capital that is being examined would necessarily disturb any prior equality between ROE, i.e., the return on equity and $r_{e}$.

\footnotetext{
${ }^{125}$ L. Kolbe, J. Read, and G. Hall, The Cost of Capital: Estimating the Rate of Return for Public Utilities (Cambridge, MA: MIT Press, 1984), pp. $35-93$
} 


\section{The Capital Asset Pricing Model Approach}

The Capital Asset Pricing Model (CAPM) is the approach best grounded in economic and financial theory. Based on an equilibrium model of investor behavior and market valuation, standard business school textbooks on corporate finance favor this approach. ${ }^{126}$

The principal advantage of the CAPM is that it provides a precise and measurable definition of risk as applied to stocks. The risk measure, called beta $(\beta)$, is proportional to the correlation between the rate of return of a particular asset with the rate of return for the market as a whole. ${ }^{127}$ This measure of risk is then related in a straightforward fashion to the cost of equity capital through the basic CAPM equation as follows:

$$
r_{e}=E\left(r_{j}\right)=r_{f}+\beta_{j} \cdot\left[E\left(r_{m}\right)-r_{f}\right],
$$

where

$$
\begin{aligned}
E\left(r_{j}\right)= & \text { the expected rate of return on asset } j \\
& \text { (i.e., the cost of equity capital) } \\
r_{1}= & \text { the current risk-free rate of return } \\
\beta_{j}= & \text { the risk measure for asset } j \\
E\left(r_{m}\right)= & \text { the expected rate of return for the } \\
& \text { market. }
\end{aligned}
$$

The CAPM asserts that the expected rate of return is just the risk-free rate, $r_{f}$ plus a risk premium that is given by the risk measure, $\beta$, multiplied by "the market price of risk." The market price of risk is the bracketed term in the CAPM expression, namely the difference between the expected rate of return for the market as a whole and the risk-free rate of return. The equivalence between the stockholders' expected rate of return and the cost of equity capital can be justified by the same argument that was used to equate the stockholders' discount rate with the cost of equity capital.

The CAPM has a number of problems in the translation from theory into practice. Difficulties arise in the estimation of all its parameters. Empirical tests of the CAPM have been ambiguous. A number of adjustments or reformulations of the CAPM have been proposed.

\section{Summary of the Estimators for the Cost of Equily Capital}

Based on the discussion in the preceding sections, the three estimators of the cost of equity capital that will be used in this analysis are:

$$
\begin{array}{cc}
\text { (DCF) } \quad r_{e}=\frac{D}{P}+\hat{g} \\
(E P R) \quad r_{e}=E / P \\
(C A P M) \quad r_{e}=r_{f}+\beta_{j} \cdot\left[E\left(r_{m}\right)-r_{f}\right] .
\end{array}
$$

Some clarification is necessary to explain the mechanism by which these estimators could reflect the changes in the cost of equity capital caused by contracts (to purchase power from nonutility generators) or commitment to capital expansion. The case of the second estimator is most straightforward; if stockholders believe that the utility's future earnings are made more risky by its commitments, then the price of stock will fall. This argument also holds for the first estimator, but in this case there is an additional effect which works through the estimate of $\mathrm{g}$. Since this estimate is provided by market analysts, their judgment concerning the impact of the utility's commitments will play a role independent of stockholder's views. The third estimator can only be affected through $\beta$, the covariance of the utility stock's rate of return with the market rate of return. Since any fluctuation in earnings must be absorbed by stockholders (i.e., the creditors having a prior claim), increasing the debt-equity ratio reduces the base over which these fluctuations are spread. ${ }^{128}$ Since stock prices depend on earnings per share, and having a smaller base means greater percentage fluctuation in earnings per share, it also means greater fluctuations in the stock price. This in turn leads to a larger $\beta$. Thus, anything that effectively increases a utility's debt-equity ratio should also increase its $\beta$.

\section{The Basic Equation Specification}

The effect of nonutility generator (NUG) contracts is hypothesized to be an effective change in the debtequity ratio, i.e., D/Eq. Therefore, to assess the impact

\footnotetext{
${ }^{126}$ R. Brealey and S. Myers, Principles of Corporate Finance, 4th Edition (New York, NY: McGraw-Hill, Inc., 1991).

${ }^{127}$ The proportionality constant is the ratio of the standard deviation of the asset's rate of return to the standard deviation of the rate of return for the market as a whole.

${ }^{128}$ For a full discussion of this effect see L. Kolbe, J. Read, and G. Hall, The Cost of Capital: Estinating the Rate of Return for Public Utilities, Appendix A (Cambridge, MA: MIT Press, 1984), pp. 137-146.
} 
of NUG contracts on the cost of equity capital, a model of the effect of the debt-equity ratio on the cost of equity capital is considered first. Two versions of this relationship are: $:^{129}$

$$
\begin{aligned}
& r_{e}=r_{w}+\left(r_{w}-r_{d}\right) \frac{D}{E q} \quad \text { and } \\
& r_{e}=r_{a e}+(1-t)\left(r_{a e}-r_{d}\right) \frac{D}{E q},
\end{aligned}
$$

where $r_{w}$ is the weighted cost of capital, $r_{d}$ is the cost of debt, $r_{e}$ is the cost of equity, $r_{a e}$ is the all-equity cost of capital, $t$ is the tax rate, $D$ is debt and $E q$ is equity.

There has been a long debate over these two positions. It is, however, not necessary to resolve this controversy. In either case, the above formulations establish that the relationship between $\mathrm{D} / \mathrm{Eq}$ and $r_{e}$ has the following form:

$$
r_{e}=\beta_{0}+\beta_{1} \frac{D}{E q} \text {. }
$$

NUG contracts have capacity payments which are thought to be equivalent to debt payments by bondrating agencies and thus imply a value for the equivalent debt. Calling this NUG "equivalent debt" Dn, the utility's debt-equity ratio can be stated in the form (D $+\alpha \cdot \mathrm{Dn}) / \mathrm{Eq}$, where $\alpha$ will be called the risk factor and indicates the extent to which Dn has a debt-like impact on the utility. This gives rise to the expanded cost of equity capital equation: ${ }^{130}$

$$
r_{e}=\beta_{0}+\beta_{1} \frac{D}{E q}+\beta_{2} \frac{\alpha \cdot D n}{E q}
$$

In order to account for the effect of utility construction projects, one more variable is added. Projected utility capital expenditures are available for only three future years and sometimes for five. This short time period does not permit an accurate computation of the present value of the projected capital expenditures (some of which might take 5 to 7 years). Thus, the best that can be done is to use the sum of projected capital expenditures for the first three years as a proxy for the future growth in capital stock. The impact of this variable, called $C$, is assumed to be proportional to its magnitude but inversely proportional to the equity base that its impact is spread over. Accordingly, it is entered in the stochastic equation as $C / E q$. This leads to the basic stochastic model:

$$
r_{e}=\beta_{0}+\beta_{1} \frac{D}{E q}+\beta_{2} \frac{D n}{E q}+\beta_{3} \frac{C}{E q}+\varepsilon .
$$

Note that equity, $E q$, acts as a normalization divisor for all three variables, thus assuring a homoscedastic error term.

If $\beta_{2}>\beta_{3}$ then the regression favors the hypothesis that buying NUG power raises the cost of capital relative to utility funded construction. To determine the statistical significance of this result, the hypothesis that $\beta_{2}=\beta_{3}$ will be tested; only if this hypothesis can be rejected can it be reliably concluded that one or the other side of the debate is probably correct.

If the bond-rating agencies are correct, then a positive relationship between purchases of nonutility power and $r_{e}$, or $\beta_{2}>0$ should be expected. The expectations for $C$ are more complicated. While the impact of projected construction expenditures on $r_{e}$ is not clearly established, the possibility for $r_{e}$ to rise as $C$ increases seems reasonable. Under conditions where $r_{e}>r$, the investment could be viewed as being favorable. This effect does not directly affect the cost of capital but can affect one of its measures. As previously noted, E/P measures the cost of capital only in the case of zero expected earnings growth. The variable $C$ in the presence of a rate of return above the cost of capital will produce an increase in expected earnings. Thus, in a favorable regulatory environment, $C$ may be negatively correlated with $E / P$. This would be indicated by $\beta_{3}<0$.

\section{An Expanded Specification}

The above basic equation focuses on the "debtequivalence" policy debate, but may omit important variables that could explain variations in the cost of equity capital. There is a tradition of modeling the cost of equity capital for electric utilities which typically includes operational and regulatory variables as well as

\footnotetext{
${ }^{129} \mathrm{~L}$. Kolbe, J. Read, and G. Hall, The Cost of Capital: Estimating the Rate of Return for Public Utilities, Appendix A (Cambridge, MA: MIT Press, 1984) for additional details. Preliminary versions were developed by Modigliani and Miller. See F. Modigliani and M. Miller, "The Cost of Capital, Corporate Finance and the Theory of Investment," American Economic Review, 48 (1958), pp. 261-297, and F. Modigliani and M. Miller, "Corporate Income Taxes and the Cost of Capital: A Correction," American Economic Review, 53 (1963), pp. 433-442.

${ }^{130}$ Since the accuracy of available estimates of $\alpha$ is not assured, in some cases $\alpha$ may be omitted.
} 
managerial and financial variables. There are potentially a number of such variables that might be added to the basic equation. Because sample size is constrained by data limits, the choice of additional variables is limited to those considered critical. Accordingly, fuel mix and "regulatory climate" are selected as among the more important sources of variation.

On the subject of fuel mix, there exists a lack of consensus. In some cases, the specification emphasizes expensive fuels, in other cases, the risks associated with nuclear power. ${ }^{131}$ Since fuel costs are currently low, nuclear power will be used as a measure of operating risk. To measure the exposure to this risk, the ratio of nuclear assets to total electric utility plant will be used by a variable NUKE. The sign of the coefficient on this variable is expected to be positive; i.e., nuclear assets increase the cost of capital because they are risky.

"Regulatory climate" is a general term which describes the degree of stringency applied by State regulatory commissions to investor-owned utilities. It is a composite of many factors including the generosity of allowed rates of return, the effect of regulatory lags, and accounting procedures. Investment and research firms regularly publish rankings of State regulation. These have been found to be significant variables in studies of the cost of equity capital. ${ }^{132}$ Regulatory factors have also been found to be a significant source of variation in the cost of electric utility debt. ${ }^{133}$ Accordingly, the variable PUC is used as the rcgulatory climate variable. ${ }^{134}$ This variable gives numerical ratings to regulatory commissions going from 1 (unfavorable to investors) to 5 (favorable to investors). The sign on the coefficient of this variable is expected to be negative; i.e., a favorable regulatory climate would reduce risk and hence also reduce the cost of capital.

Adding these two additional variables results in an expanded specification with the following form:

$$
\begin{aligned}
r_{e} & =\beta_{0}+\beta_{1} \frac{D}{E q}+\beta_{2} \frac{D n}{E q}+\beta_{3} \frac{C}{E q} \\
& +\beta_{4} N U K E+\beta_{5} P U C+\varepsilon .
\end{aligned}
$$

The above expanded form will also be tested to examine whether it has more explanatory power than the basic equation.

\section{Measurement Issues}

\section{Definitions of Regression Variables}

Each of the regressions derived from the basic equation makes use of four variables: utility's cost of equity capital, $r_{e}$ debt-equity ratio, ratio of imputed debt obligation attributable to power purchases by a utility from nonutilities, "debt" to equity (i.e., NUG), and projected utility capital expenditures $(C)$. This section defines those variables in terms of constituent variables that are available from sources that are discussed later in this section.

The utility cost of equity capital, $r_{c}$ can be measured through three different proxies: (1) the DCF approach, (2) its variant the EPR, or (3) the CAPM approach. Each is tested as a dependent variable. The required constituent variables are:
1) $\mathrm{D}=$ the stock dividend,
$\mathrm{P}=$ the stock price,
$8=$ the expected growth rate of the divi- dend.
2) $\mathrm{E}=$ earnings,
$P=$ the stock price.
3) $\beta=$ beta, the covariance of the stocks return over the variance of market return,
$r_{f}=$ the risk-free rate of return,
$E\left(r_{m}\right)=$ the expected market rate of return.

$D / E \quad$ The debt-equity ratio is self explanatory; it requires $x_{1}$, the utility's debt ratio (debt divided by debt plus equity).

\footnotetext{
${ }^{131}$ J. Dubin, and P. Navarro, "Regulatory Climate and the Cost of Capital," Regulatory Reform and Public Utilities, ed. M. Crew (Lexington, MA: Lexington Books, 1982) and R. Bowen, R. Castanias, and L. Daly, "Intra-Industry Effects of the Accident at Three Mile Island," Journal of Financial and Quantitative Analysis, Vol. 18, No. 1 (1983), pp. 87-107.

${ }^{132}$ J. Dubin, and P. Navarro, "Regulatory Climate and the Cost of Capital," Regulatory Reform and Public Utilities, ed. M. Crew (Lexington, MA: Lexington Books, 1982), pp. 141-166.

${ }^{133}$ R. Prager, "The Effects of Regulatory Policies on the Cost of Debt for Electric Utilities: An Empirical Investigation," Journal of Business, Vol. 62, No. 1 (1989), pp. 33-53.

${ }^{134}$ The variable PUC is based on data available from Merrill Lynch. See "Utility Industry: Opinions on Regulation" (New York, January 1993).
} 
C:

Projected capital expenditures (normalized). This variable is forecast by the utility, and includes construction expenses for transmission and distribution as well as for generation. It is typically not forecast very far into the future (3-5 years). This variable must be present valued and normalized to account for variations in firm size. Since its effect on the cost of equity capital will be inversely proportional to the value of the firm's equity, just as is true with debt, $C$ is normalized by dividing by the firm's equity. Thus, $C$ is defined as:

$$
C=P C A P / E q,
$$

where

$$
\begin{aligned}
P C A P & =\begin{array}{l}
\text { Projected utility capital expendi- } \\
\text { tures, }
\end{array} \\
E q & =\text { Equity }
\end{aligned}
$$

NUG: This is a pseudo "debt"-equity ratio due to capacity payments to nonutility generators, and must reflect the multi-year commitment to those generators. The present-value of this payment stream represents a first approximation to their debt equivalence. As a second approximation, the Standard and Poor's utility-specific "risk factors" are used as a means of weighting these payments to account for differences in terms and conditions of the contracts. NUG and its constituent variables are defined as follows:

$$
\begin{aligned}
& \mathrm{NUG}_{1}=\mathrm{Dn} / \mathrm{Eq}=\left(\mathrm{x}_{2}-\mathrm{x}_{1}\right) /\left(1-\mathrm{x}_{1}\right)\left(1-\mathrm{x}_{2}\right), \\
& \mathrm{NUG}_{2}=\alpha \cdot \mathrm{Dn} / \mathrm{Eq} \text {, } \\
& \text { Dn = Equivalent "debt" due to NUG } \\
& \text { (derived from } x_{1} \text { and } x_{2} \text { ), } \\
& x_{1}=\text { standard debt ratio, } \\
& x_{2}=\text { debt ratio "adjusted" for NUGs, } \\
& \alpha=\text { Standard and Poor's "risk factor." }
\end{aligned}
$$

A detailed discussion of variables follows, though it should be noted that alternative approaches are pos- sible, one of which would be to construct a NUG variable from EIA data on NUG capacity using proxy costs for different fuel types.

To explain the constituent variables, data available from Moody's are used. ${ }^{135}$ Moody's presents a table giving an unadjusted and an adjusted debt fraction for each of 51 investor owned utilities. It is useful to give explicit definitions of these concepts. First, the standard (or unadjusted) debt fraction is given by:

$$
x_{1}=\frac{D b}{D b+E q} \text {, }
$$

where $x_{1}$ is the debt fraction, $D b$ is the total amount of debt and $E q$ is the total amount of equity (including preferred shares). The adjusted debt fraction is given by:

$$
x_{2}=\frac{(D b+D n)}{(D b+D n)+E q},
$$

where $D n$ is the equivalent debt associated with power purchases. Since, the variable $\mathrm{NUG}_{1}=\mathrm{Dn} / \mathrm{Eq}$ instead of $x_{2}$ is required for the regression, NUG should be solved in terms of $x_{1}$ and $x_{2}$. This is easily done by defining $d n=D n /(D b+E q)$, and $e q=E q /(D b+E q)$, and noting that $\mathrm{Dn} / \mathrm{Eq}=\mathrm{dn} / \mathrm{eq}$. It can be shown that:

$$
d n=\frac{x_{2}-x_{1}}{1-x_{2}}, \quad \text { and } \quad e q=1-x_{1} .
$$

This implies the first formula for $\mathrm{NUG}_{1}$ given above.

The equivalent debt, $D n$, is a capitalization of capacity or demand-related payments. The bond-rating agencies make calculations of this kind. Moody's uses certain simplifying assumptions to standardize their calculation of Dn. They assume that 60 percent of annual purchased power payments are capacity-related, ${ }^{136}$ that contracts are 25 years in length, and that the presentvalue of the future capacity payment stream should be discounted at 10 percent. ${ }^{137}$ They assert that this

\footnotetext{
${ }^{135}$ Moody's Investor Services, "Moody's Continues to Weigh the Credit Risks of Purchased Power on Electric Utility Credit Quality" (September 1992).

${ }^{136}$ The 60 percent figure is difficult to verify for a number of reasons, the foremost of which is dispatchability. Capacity payments are fixed, while total power purchase costs depend upon dispatch. A recent study of private power pricing found that capacity related payments were typical'y closer to 50 percent for high capacity factor operation. At low capacity factor, however, portions in excess of 70 percent can be expec'ed. See E. Kahn, A. Milne, and S. Kito, The Price of Electricity from Private Producers, LBL-34578 (Berkeley, CA, 1993).

${ }^{137}$ Moody's Investor Services, "Moody's Continues to Weigh the Credit Risks of Purchased Power on Electric Utility Credit Quality" (Septemier 1992).
} 
results in assuming that every $\$ 1$ in annual capacity payments is equivalent to $\$ 6.5$ in imputed debt. ${ }^{138}$ Duff and Phelps uses a capitalization method which results in a much smaller equivalent debt. ${ }^{139}$ They assume that only 20 percent of purchased power expense is capacity charges, but they capitalize this at 10 times, resulting in an equivalent debt that is 2 times annual purchase power costs. Although these methods are somewhat arbitrary, because they affect all NUG values by a constant factor they will bias the $\mathrm{NUG}_{1}$ coefficient, but they will not affect its $\mathrm{t}$-statistic.

An important issue that should be examined is whether differences in the risk characteristics of NUG contracts are reflected in the NUG variable. If NUG values could be correctly adjusted for risk, that should improve the t-statistic; in other words, it would make the statistical tests more sensitive. The Standard and Poor's approach to this issue allows for variation in risk by using a "risk factor." To illustrate how this works, if the appropriate risk factor is designated by $\alpha$, then a "risk adjusted NUG 'debt'-equity ratio," $\mathrm{NUG}_{2}$, can be expressed as follows:

$$
N U G_{2}=\frac{\alpha \cdot D n}{E q} .
$$

Table $\mathrm{C} 1$ provides an illustration of the differences between the definitions of $\mathrm{NUG}_{1}$ and $\mathrm{NUG}_{2}$. This example takes two utilities that are highly dependent on purchased power and computes the quantities defined above. The estimates of the risk factor $\alpha$ are attributed to Standard and Poor's. ${ }^{140}$

These calculations show that the Moody's method estimates a substantially greater equivalent debt for South- ern California Edison (SCE) than for Consumers Power (CP), although both are quite large compared to the strictly financial debt. As a result, $\mathrm{NUG}_{1}$ is bigger for SCE than for $\mathrm{CP}$, even though the unadjusted aebt fraction for SCE is quite a bit lower. When risk is taken into account, however, the rank ordering reverses. The risk factor for $\mathrm{CP}$ is much greater than for SCE.

The actual construction of the NUG variables is complicated by the fact that the available data produces a ratio of Dn to book equity, while what is needed is the ratio of $D n$ to the market value of equity. Conversion from one to the other, which requires the use of the book-to-market ratio (B:M) is described later in this Appendix.

\section{Definitions and Sources of Constituent Variables}

In the previous section, all of the variables needed to construct the four regression variables were listed. In this section, these constituent variables are defined with more precision and indicate the source of values for each. Because PCAP data are only available for December 31, 1992, an attempt was made to find values for all other variables that are either valid at that date or a good proxy for the value at that date.

Dividend (D): Annual dividend yield reported by Value Line. Data for utilities in the west from the November 27, 1992 issue; data for utilities in the east from the December 18, 1992 issue; data for utilities in the midwest from the January 15, 1993 issue.

Table C1. NUG “Debt"-Equity Ratios

\begin{tabular}{|c|c|c|c|c|c|}
\hline \multirow[b]{3}{*}{ Company } & \multirow[b]{2}{*}{ Debt Ratio } & \multirow{2}{*}{$\begin{array}{c}\text { Adjusted } \\
\text { Debt Ratio }\end{array}$} & \multirow{2}{*}{$\begin{array}{c}\text { Risk } \\
\text { Factor }\end{array}$} & \multicolumn{2}{|c|}{ "Debt"-Equity Ratio } \\
\hline & & & & \multicolumn{2}{|c|}{ Risk Adjusted } \\
\hline & $x_{1}$ & $x_{2}$ & $\alpha$ & $N \cup G_{1}$ & $\mathrm{NUG}_{2}$ \\
\hline Consumers Power & .601 & .738 & .3 & 1.31 & 0.39 \\
\hline Southern California Edison & .552 & .743 & .1 & 1.66 & 0.17 \\
\hline
\end{tabular}

\footnotetext{
${ }^{138}$ There is some ambiguity in the Moody's estimate. Taken literally, their method amounts to capitalizing capacity payments at a factor of 9 , and total purchased power expense at a factor of $5.4\left(=0.6^{*} 9\right)$. As explained in the footnote to Table $\mathrm{C} 2$, the actual capitalization factor used by Moody's seems to be 3.9 times total purchase power expense.

${ }^{139}$ Duff and Phelps, "The Purchase Power Commitment" (1992).

${ }^{140}$ Estimates of $\alpha$ in Table $\mathrm{C} 1$ are taken from T. Mockler who attributes them to Standard and Poor's. See T. Mockler, "Testimony in California Public Utilities Commission," Appl. No. 93-05-08 et al. (1993).
} 
Market Price of Common Stock (P): Market value of common stock on December 31, 1992 from annual reports. "Recent Price" per share from Value Line was used for thirteen companies that did not report yearend stock price in annual report.

Book Value of Common Stock: Book value of common stock as of December 31, 1992 from individual reports.

Book Value of Preferred Stock: Total value of all classes of preferred stock as of December 31, 1992 from annual reports.

Book-to-Market Ratio (B:M): From Merrill Lynch.

Estimated future growth rate of dividends $(\hat{\xi})$ : Value Line's estimated growth in dividends using 1989-1991 as the starting period and 1995 to 1997 as the ending period.

Earnings Per Share (E): Average of 1992 and 1993 earnings per share was used in this analysis. 1992 values are from individual annual reports. 1993 values are based on Value Line estimates.

Beta ( $\beta$ ): The stock's beta taken from Merrill Lynch. ${ }^{141}$

Risk-Free Rate of Return ( $\left.r_{f}\right)$ : From Brealey and Myers. ${ }^{142}$

Expected Market Rate of Return $\left(E\left(r_{m}\right)\right)$ : From Brealey and Myers.

Utility's Debt Ratio $\left(x_{1}\right)$ : From Duff and Phelps' estimate from 1992 data.

Projected utility capital expenditures (PCAP): From SEC 10-K forms, as of December 31, 1992. Total electric construction expenditures were used.

"Adjusted" debt ratio $\left(x_{2}\right)$ : From Duff and Phelps' estimate from 1992 data.

Standard and Poor's "risk factor" $(\alpha)$ : Standard and Poor's, as summarized in Mockler. ${ }^{143}$

\section{Data Quality Issues}

\section{Holding Companies}

A minor issue involves the question of utility holding companies. A holding company typically is the sole owner of the common stock of its operating subsidiaries. Therefore, only the holding company's stock is publicly traded. The operating companies which are subsidiaries of a holding company may have substantially different commitments to construction and NUG contracts. For example, Jersey Central Power and Light (JCPL) and Metropolitan Edison Company (Met Ed), both subsidiaries of General Public Utilities (GPU), purchased more than 10 percent of their capacity from NUGs in $1991 . .^{144}$ GPU's other subsidiary, Pennsylvania Electric (Penelec) has less dependence on NUGs. To represent the NUG variable for GPU, representation for each subsidiary is weighted by the capital structure of the holding company.

\section{NUG Data}

In principle, data on NUGs for year-end 1992 are proposed to be used. The only publicly available estimates for that time period are those from Duff and Phelps which constitute the starting point. ${ }^{145}$ The choice is not unambiguous, however, because the Duff and Phelps estimation method is somewhat mechanical, and may include purchases, such as short-term economy energy, that are in no way equivalent to debt. The main competing source of data on NUG debt equivalence is Moody's 1991 estimate. This estimate may be more selective. There is a problem, however, with its being one year out of phase with other variables. The most extreme example of this time lag problem is illustrated below.

If the dependence of individual utilities upon NUG purchases were stable between 1991 and 1992, then using 1991 as a proxy for 1992 would be reasonable. Unfortunately, it is not. The best, if most extreme, example of this is the Niagara Mohawk Power Corporation (NMPC). Table C2 summarizes the problem.

\footnotetext{
${ }^{141}$ Merrill Lynch, Global Research Review (February 1993).

${ }^{112}$ R. Brealey and S. Myers, Principles of Corporate Finance, 4th Edition (New York, NY: McGraw-Hill, Inc., 1991).

${ }^{143}$ T. Mockler, "Testimony in California Public Utilities Commission," Appl. No. 93-05-08 et al. (1993).

${ }^{14}$ Energy Information Administration, Financial Statistics of Selected Investor-Owned Electric Utilities 1990, DOE/EIA-0437/(90)/1 (Washington, DC, January 1992).

${ }^{115}$ Duff and Phelps, "Electrics: By the Numbers" (July 1993).
} 
Table C2. NMPC Debt Fractions for 1991 and 1992

\begin{tabular}{|c|c|c|c|c|c|}
\hline Year & $\begin{array}{c}\text { Debt } \\
\text { (Millions) }\end{array}$ & $\begin{array}{l}\text { Equity } \\
\text { (Millions) }\end{array}$ & $\begin{array}{l}\text { Unadjusted } \\
\text { Debt Ratlo }\end{array}$ & $\begin{array}{l}\text { Purchased } \\
\text { Power } \\
\text { (Millions) }\end{array}$ & $\begin{array}{l}\text { Adjusted } \\
\text { Debt Ratio }\end{array}$ \\
\hline 1991 & 3625 & 2627 & 0.580 & 394 & 0.664 \\
\hline$\ldots \ldots \ldots \ldots$ & 3776 & 2700 & 0.583 & 659 & 0.701 \\
\hline
\end{tabular}

The calculations in Table C2 are based on Moody's 1991 calculation of the adjusted debt ratio and NMPC's 1992 Annual Report. The term "Debt" includes long term debt, short term debt and long term debt due within one year. "Equity" includes both common and preferred. The adjusted debt ratio is computed using Moody's capitalization method. ${ }^{146}$

The change in the adjusted debt ratio in Table C2 reflects the substantial growth in NUG payments by NMPC between 1991 and 1992. Other utilities, such as Consumers Power or Southern California Edison, did not experience such large changes between 1991 and 1992.

As an alternative to the direct estimates of debt equivalence, a physical approach is also possible. Data on NUG energy purchases and capacity commitments of utilities as of 1991 are collected by th.e Energy Information Administration (EIA). This data has the advantage of eliminating other purchases, such as short-term economy energy, from consideration. As an alternative to the financial NUG variables, based on Duff and Phelps data, a physical NUG variable called $\mathrm{NUG}_{3}$ is also tested. $\mathrm{NUG}_{3}$ is defined as the ratio of NUG energy purchases to total sources of energy for 1991.

\section{Financially Distressed Utilities}

A number of companies that might potentially be included in the sample are experiencing financial distress for one reason or another. This shows up in some of the cost of capital estimators in a number of anomalous ways. Value Line estimates the future dividend growth for Commonwealth Edison, for example, to be negative 7 percent. This would give a very low DCF $r_{e}$, which may not make sense since their beta is among the highest in the sample. The same arguments apply to Pinnacle West (i.e., Arizona Public Service).
There are two different approaches to deal with these situations. One option is to eliminate such companies from the data base, and use regressions estimated on a smaller sample. Alternatively, proxy costs of capital for these firms can be used. The idea for a proxy is that intuitively it is known that these are high risk firms. Therefore, they must have a high cost of capital. For some reason, the standard estimators do not result in a high risk $r_{e}$ being assigned to them. As a proxy, such utilities are assigned a cost of capital that is arbitrarily higher than any observed in the sample, so that the anomalous data do not distort the analysis. For each cost of capital estimator, it is assumed that the financially distressed firms have a "true" value that is 10 percent more than the highest value observed. Thus for the DCF estimator, the highest observed value is 12.6 percent. By this procedure, 13.86 percent is used for the financially distressed firms.

Although it is preferable to exclude the financially distressed firms completely (to avoid the use of the proxy $\left.r_{e}\right)$, as discussed below, this is not possible in all cases due to other considerations.

\section{Sample Selection}

Sample selection is crucial to the outcome of any statistical analysis, and both size of sample and method of selection deserve careful attention. The sample size is examined.

\section{Sample Size}

There is no question but that increasing the sample size is valuable, especially for a relatively small sample. However, additional data points often come with attendant statistical problems. Common among these is autocorrelation. When analyzing time series data there

\footnotetext{
146 The 1991 value is Moody's estimate; see Moody's Investor Services, "Moody's Continues to Weigh the Credit Risks of Purchased Power on Electric Utility Credit Quality" (September 1992). If the $\$ 394$ million is capitalized at a factor of 3.9, the stated adjusted debt ratio is 0.664 . Using a greater capitalization factor (as potentially indicated in note 136 above) would result in a larger adjustment. The 1992 data are used with a factor of 3.9 to produce the estimate given in Table C2.
} 
is always a threshold beyond which increasing autocorrelation will negate the benefit of a higher sample rate. Thus adding an adjacent year of data would add almost no new information to the current sample. It would however require that a difficult correction for autocorrelation be made. ${ }^{147}$ Added to the autocorrelation problem is the fact that the year chosen was the one for which data was most readily available, so extending to previous years would mean decreasing the average reliability of the sample.

The second method of increasing sample size is to include more utilities. This process has already been pursued vigorously and it is not evident that more data points can be added without sacrificing reliability or incurring undue cost.

\section{Selection Bias}

There are many ways to bias statistical results by improper sample selection, but perhaps the best known is truncation bias. This occurs when sample points with either high or low values of the dependent variable are omitted. This is best understood by considering a one variable regression with a regression line sloping up to the right. If points with a high y-value are omitted they will tend to be at the right end of the data set. Thus, their omission will lower the average value for points on the right and reduce the estimated slope of the regression line. This produces a biased (and inconsistent) estimate of the slope coefficient.

Another type of sample selection chooses data points based on the value of an independent variable. This, by itself, does not bias coefficient estimates. In fact, the statistical model on which multiple linear regression is premised assumes that an experimenter chooses the values of the independent variables not by some statistically random technique, but entirely deliberately. Based on this premise, an experiment in which several utilities were instructed to implement a very high NUG value and an equal number of others were instructed to have a NUG value of zero would be the ideal. Barring that possibility, the sample includes as many firms as possible with high NUG values, since the low NUGvalue end of the sample tended to be well enough represented. The point of including extreme values is to increase the accuracy of the estimates of the coefficients; points near the middle of the range tell nothing about the slope of the relationship between the cost of capital and the value of NUG.

The above problem can be approached more rigorously as follows. Note that the problem of truncation bias has been well known since the late $1950 \mathrm{~s} .{ }^{148}$ The more recent analysis on this subject by Heckman contends that there will be no selection bias "in the case of independence between $U_{1 i}$ and $U_{2 i}$," where $U_{1 i}$ are the regression equation errors and $U_{2 \mathrm{i}}$ are the selection equation errors. ${ }^{149}$ Accordingly, the selection criteria for utilities had a form that can be simply approximated as follows:

$$
\text { Include the data point if } \mathrm{NUG}-\beta+\mathrm{U}_{2 \mathrm{i}}>0 \text {. }
$$

Clearly, for any selection parameter, higher values of NUG are more likely to be included. The error term is related only to the convenience of acquiring data, which should be unrelated to the error term in the regressions. It should also be noted that if observations with NUG $>\beta$ had been selected, the error term would have been zero. If the selection error term is zero, it is certainly independent of the regression error term. Thus, using Heckman's formal model confirms that the selection based on NUG values should not bias any coefficients.

\section{Bias from Omitting Financially Distressed Utilities}

There is one way in which the study does run the risk of truncation bias. Heckman warns: "in studies of panel data, it is common to use 'intact' observations. . . . Such procedures have the same effect on structural estimates as self selection: fitted regression functions confound the behavioral parameters of interest with parameters of the function determining the probability of entrance into the sample." In this study, "intact" observations are those utilities that are not financially distressed, so Heckman is warning that the distressed utilities should not be omitted. In defining the sample selection, there were seven financially distressed utilities as indicated by the fact that they were not paying dividends, or the fact that stock analysts were assigning negative growth rates to their dividends, or not even estimating dividend growth rate. Of these seven, five

\footnotetext{
${ }^{147}$ Difficult because each time series would only be two periods long and this is not the case normally covered in the literature.

${ }^{148} \mathrm{H}$. Theil, "Specification Errors and the Estimation of Economic Relationships," Reoue de l'Institut International de Statistique, Vol. 25 (1957), pp. 41-51.

${ }^{149} \mathrm{~J}$. Heckman, "Sample Selection Bias as a Specification Error," Econometrica, Vol. 47, No. 1 (January 1979).
} 
were omitted and two with the largest NUG values were retained. The omission of the five should be expected to bias the coefficients but not in a direction that would undermine the conclusions. Empirical implications of this selection bias are discussed later in this Appendix.

\section{Special Cases}

There are a number of cases where holding companies have substantial assets in nonutility businesses. Two particularly important examples of this kind are Southern California Edison and Consumers Power. In both instances the nonutility generation projects sell very substantial quantities of power to the affiliated utility. These cases have attracted much attention from State regulators, who have expressed concern about self-dealing, and have imposed financial penalties on the utilities in question. ${ }^{150}$ Because both of these companies are among the largest NUG purchasers, it is not desirable to exclude them from the analysis. Yet the very special circumstances involving the self-dealing issue require that separate regressions be run with these companies in and out of the sample, so that the effects of their special circumstances can be isolated. The distressed financial condition of Consumers Power's parent company, CMS Energy, requires the use of the proxy method described above for its cost of capital.

\section{Methodology for Constructing Variables}

\section{Cost of Capital Variables}

The input and final regression variables used to represent the three dependent variables are presented below. These variables include a capital-asset pricing model (CAPM) estimate, a discounted cash flow (DCF) estimate, and an earnings-price (EP) estimate. For each measure, an "Unadjusted" and an "Adjusted" value is reported. Unadjusted values were calculated according to the methodology outlined below. The "Unadjusted" values do not accurately reflect the cost of capital for financially distressed firms. As a proxy, such utilities are assigned a cost of capital that is arbitrarily higher than any observed in the sample, so that the anomalous data do not distort the analysis. For each cost of capital estimator, it is assumed that the financially distressed firms have a "true" value that is 10 percent more than the highest value observed.

\section{Capital Asset Pricing Model}

CAPM is calculated for each company using the following equation:

$$
C A P M=R_{R F}+\left(R_{M}-R_{R F}\right) \cdot \text { Beta , }
$$

where $R_{R F}$ equals risk free rate of return, $R_{M}$ equals market rate of return, and Beta equals the covariance of the stock's return over the market return. Values for risk free return and market return are from Brealey and Myers. These values are the same across companies. Values for Beta are company-specific and are from Value Line.

\section{Discounted Cash Flow}

DCF is calculated for each company using the following equation:

$$
D C F=\text { Dividend Yield }+ \text { Dividend Growth } .
$$

Dividend data are from Value Line.

\section{Earnings/Price}

$\mathrm{E} / \mathrm{P}$ is simply the earnings per share for 1992 divided by the stock price at the end of 1992 .

\section{Projected Construction Expenditures Variable - C}

Below are the input and final regression variables used for the independent variable - projected construction expenditures $-C$. First, projected annual construction expenditures are obtained for 1993 to 1995 from each company's SEC 10-K filing. The net present value of these expenditures is calculated using a 10-percent discount rate. The net present value figure to equity is

\footnotetext{
${ }^{150}$ For details involving Southern California Edison, see California Public Utilities Commission, Decision No. 90-09-088 (1990); also, see California Public Utilities Commission, Decision No. 93-03-021 (1993). For Consumers Power, there is a good description in the financing documents associated with their affiliated NUG project known as Midland Cogeneration Venture; see Stone and Webster Management Consultants Inc., "Feasibility Report for the Midland Cogeneration Venture," in Midland Cogeneration Venture Limited Partnership, Prospectus \$999,905,607 Midland Funding Secured Lease Obligation Bonds (1991).
} 
then normalized. The following equation describes this procedure:

$$
C=\frac{N P V(C 93+C 94+C 95)}{\text { Book Equity }} \cdot \frac{\text { Book Price }}{\text { Market Price }} .
$$

\section{Computing the D/E and NUG1, NUG2, NUG3 Variables}

Input, intermediate and final regression variables used to represent the debt-equity ratio and non-utility generation are presented below. The definition of the variables can be found earlier in this Appendix.

The first four intermediate variables are determined as follows:

$$
\begin{aligned}
U D: E & =\frac{U D: C}{U E: C}, \\
n u g 1 & =\frac{A D: C-U D: C}{(1-U D: C)(1-A D: C)}, \\
n u g 2 & =\alpha \cdot n u g 1, \\
E p c & =E q P / E q C .
\end{aligned}
$$

$U D: E$ is unadjusted debt/equity. $U D: C$ is unadjusted debt/capital. UE:C is unadjusted equity/capital. $A D: C$ is debt/capital adjusted for NUGS. "nug1" is NUG1 before equity is converted to market value (nug2 is similar). $E q P$ is preferred equity, and $E q C$ is common equity. $\alpha$ is Standard and Poor's "risk factor."

The second four intermediate variables are determined as follows:

$$
\begin{aligned}
& D: E c=U D: E+E p c+U D: E \cdot E p c, \\
& N 1 c=n u g 1+n u g 1 \cdot E p c, \\
& N 2 c=n u g 2+n u g 2 \cdot E p c, \\
& B: M=B V / M V .
\end{aligned}
$$

$D: E c$ is the ratio of debt to common equity. N1c and $N 2 c$ are the NUG variables computed as a ratio to common book equity. $B: M$ is the ratio of book to market value.
Finally, the four independent regression variables are determined as follows:

$$
\begin{aligned}
D: E m & =D: E c \cdot B: M, \\
N U G 1 & =N 1 c \cdot B: M, \\
N U G 2 & =N 2 c \cdot B: M, \\
N U G 3 & =\text { input. }
\end{aligned}
$$

The first two NUG variables have now been expressed as a ratio of NUG debt to the market value of common equity.

\section{Characteristics of Regression Variables and Regression Runs}

A listing of the total number of specifications of the basic equation tested numerically is provided. There are three versions of the cost of capital variable: (1) CAPM, (2) DCF, and (3) EPR. For each of these dependent variables the three NUG variables will be used. NUG is the 1992 Duff and Phelps estimate, suitably normalized. NUG ${ }_{2}$ applies the Standard and Poor's risk factor to $\mathrm{NUG}_{1} . \mathrm{NUG}_{3}$ is the 1991 physical NUG variable, taken from EIA Form-867 data on nonutility purchases. Finally, there were two samples that were used in the regression analysis. These two samples have two utilities that are sometimes included and excluded at other times. The two utilities are: SCE Corporation and CMS Energy-holding companies for Southern California Edison and Consumers Power, respectively. If the basic sample of utilities excludes SCE and CMS, the cases are designated as " $\mathrm{N}$ " for no self-dealing and if SCE and CMS are included, the cases are designated " $\mathrm{S}$ ".

Each regression uses as independent variables both the debt-equity ratio, $\mathrm{D} / \mathrm{E}$, and a measure of projected construction expenditures, $C$. Also included as an independent variable is one of three measures of nonutility generation, NUG1, NUG2, or NUG3. The dependent variable is the cost of equity capital, labelled either CAPM, DCF, or EP based on which version is being used. This section presents their standard summary statistics. For the purpose of calculating the summary statistics, all utilities that are used in any regression have been included. ${ }^{151}$ Table C 3 gives the mean and standard deviation of each variable.

\footnotetext{
${ }^{151}$ Three utilities are sometimes included and sometimes excluded in regressions. These are: Niagara Mohawk Power Corporation, CMS Energy Corporation, and SCE Corporation.
} 
Table C3. Descriptive Statistics

\begin{tabular}{l|c|c|c|c|c|c|c|c|c|c}
\hline & CAPM & DCF & EP & NUG1 & NUG2 & NUG3 & D/E & C & NUKE & PUC \\
\hline Average $\ldots \ldots \ldots \ldots \ldots$ & 0.104 & 0.094 & 0.078 & 0.189 & 0.024 & 0.058 & 0.884 & 0.291 & 0.257 & 2.971 \\
Standard Deviation $\ldots \ldots$ & 0.011 & 0.012 & 0.018 & 0.214 & 0.031 & 0.079 & 0.306 & 0.104 & 0.156 & 0.784 \\
\hline
\end{tabular}

Since both the NUG and cost-of-capital variables are estimated in three separate ways, it is interesting to see just how closely correlated they are. To that end, a standard correlation matrix for each is presented.

Note that the correlation of CAPM and DCF is quite low (Table C4). This is attributable to the poor quality of DCF as a measure of the cost of equity capital. Notice also that NUG3, the physical measure of NUG capacity, does not correlate especially well with the two financial measures, NUG1 and NUG2 (Table C5). In this case, measurement errors are suspected in all three variables.

\section{Table C4. Correlations Among Cost-of-Capital Variables}

\begin{tabular}{l|c|c|c}
\hline & CAPM & DCF & EP \\
\hline CAPM $\ldots \ldots \ldots \ldots$ & 1 & & \\
DCF $\ldots \ldots \ldots \ldots \ldots$ & 0.39 & 1 & \\
EP $\ldots \ldots \ldots \ldots \ldots$ & 0.59 & 0.56 & 1 \\
\hline
\end{tabular}

Table C5. Correlations Among NUG Variables

\begin{tabular}{|c|c|c|c|}
\hline & NUG1 & NUG2 & NUG3 \\
\hline NUG1 & 1 & & \\
\hline NUG2 & 0.85 & 1 & \\
\hline NUG3 & 0.61 & 0.60 & 1 \\
\hline
\end{tabular}

\section{Regression Results of the Basic Model}

Regression results of basic model runs are listed in Table C6 for CAPM, Table C8 for DCF and Table C 9 for
EPR. ${ }^{152}$ For each variable, the estimated coefficient is given, with the $t$-statistic listed in parentheses below it. ${ }^{153}$ Note that $t$-statistics in excess of 2 are required for statistical significance at the 95 percent confidence level. Six sets of results are given for each of the three basic models. The ' $\mathrm{S}$ ' or ' $\mathrm{N}$ ' notation indicates the inclusion or exclusion of two outlier utilities in the sample. The notation 1, 2, or 3 indicates which specification for the variable NUG is being used in the regression.

\section{CAPM}

The CAPM specification of the basic equation has the most explanatory power based on both its adjusted $R^{2}$ and on the number of significant coefficients. ${ }^{154}$ On theoretical grounds, the Debt/Equity variable is expected to be positive and significant. It is primarily in the CAPM specification that this turns out to be the case. The DCF results (Table C8) do not show a significant coefficient for the Debt/Equity variable. The EPR results (Table C9) show only marginal significance for this variable.

With respect to the central question, the CAPM specification gives unambiguous results. The $C$ variable has a positive and significant coefficient. There is no significance to the NUG coefficient. This result suggests that utility construction does increase risk and raise the utility cost of equity capital.

It is worth noting that the $\mathrm{S}$ versions of the regression have much higher $t$-statistics on the $C$ variable than the $\mathrm{N}$ versions. ${ }^{155}$ This is largely due to CMS, which has both the highest values of the CAPM $r_{e}$ and the C variables. ${ }^{156}$

\footnotetext{
${ }^{152}$ The results are based on a sample of 35 investor-owned utilities as listed in Table C15.

${ }^{153}$ The $t$-statistic (also called the Student $t$ ) permits analysts to test hypotheses involving normally distributed variables. Where the population size is small (usually less than 100), the $t$-distribution table is commonly used to determine whether sample averages are significantly different from hypothesized population means. Note that there exists a separate t-distribution for each sample size as a function of degrees of freedom, i.e., the number of values in a data set that are free to vary when restrictions are placed on the data. With degrees of freedom below 60 , the value exceeds 2.000 at confidence levels of 95 percent (in a two-tailed test).

${ }^{154} \mathrm{R}$-square is a test statistic measure between 0 and 1 . It is supposed to represent the proportion of the variation in the dependent variable "explained" by the variation in the independent variables. "Adjusted R-square" takes degrees of freedom into account.

${ }^{155} \mathrm{As}$ indicated earlier, runs with SCE and CMS are designated ' $\mathrm{S}$ ' and without these are designated ' $\mathrm{N}$ '.

${ }^{156} \mathrm{CMS}$ Energy Corporation is the holding company for Consumers Power Company in Michigan and SCE Corporation is the holding company for Southern California Edison Co. in California.
} 
Table C6. Capital Asset Pricing Model Regression Results

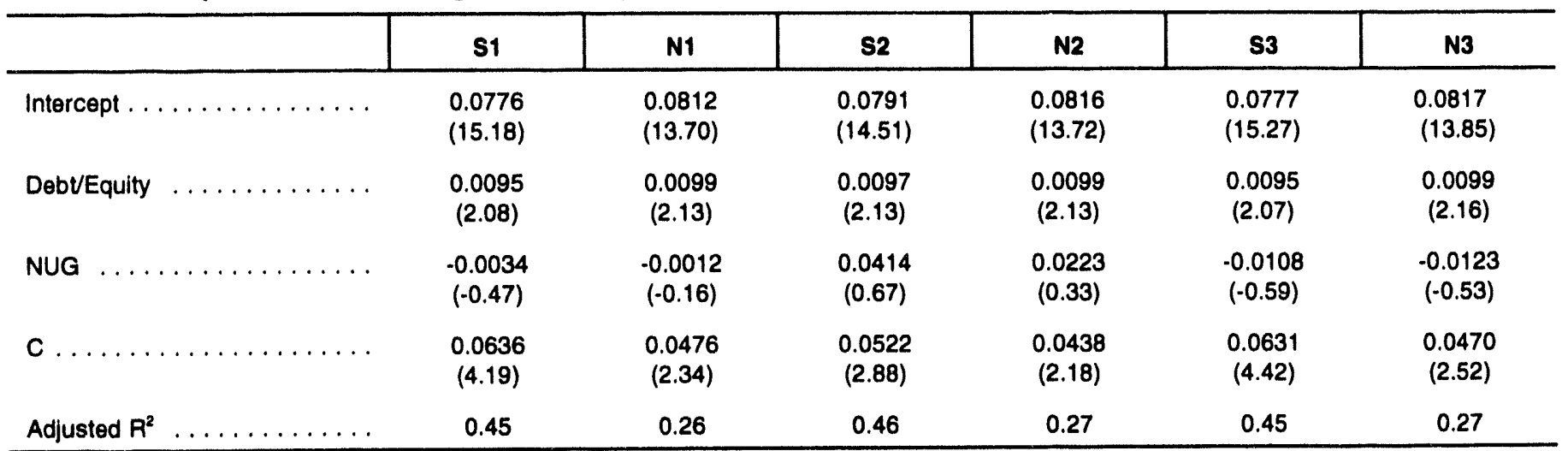

The coefficients in Table $\mathrm{C} 6$ have a straightforward interpretation. The average $r_{e}$ consists of three components: (1) the intercept term has a value of approximately 0.08 , (2) the Debt/Equity coefficient of approximately 0.01 adds a return requirement of about 0.0088 for the average value of the Debt/Equity variable of about 0.88 , and (3) the $C$ coefficient of about 0.05 adds a return requirement of about 0.015 for an average value of the $C$ variable of 0.29 . The result is an average cost of equity capital of about 0.1038 , which is approximately the average value of $r_{e}$ (Table C3). For a utility with $C$ that is one standard deviation above the average, the cost of capital increases by 0.005 .

The omission of outlier utilities (i.e., the financially distressed utilities) raises the issue of selection bias affecting coefficient estimates. Outlier utilities will almost certainly have a high cost of capital; thus, omitting them from the sample effectively truncates the sample from above. The result is to reduce, in magnitude, the estimates of all regression coefficients. The fact that the two such outliers with the largest NUG values were retained in the sample will result in the NUG coefficient estimate being less biased than other coefficient estimates. Thus the $\mathrm{C}$ coefficient is probably larger and more significant than it was expected to be, and so is the NUG coefficient, but the effect is less for NUG. This means that the results indicating that the $C$ coefficient is larger than the NUG coefficients would probably be more certain if the omitted utilities had been included.

The CAPM regressions can also be used to test whether the results contribute meaningfully to the build versus buy debate by conducting a statistical test of the hypothesis that the NUG coefficient is equal to the $C$ coefficient. Four of the six regressions strongly reject this hypothesis while two contradict it only weakly. These tests were conducted by computing an F statistic based on the $R^{2}$ of the full regression and the $R^{2}$ of a regression in which the NUG and C coefficients were restricted to be equal. This $F$ statistic is useful for testing the hypothesis that the coefficients are in fact equal. Since in each case the $C$ coefficient is greater than the NUG coefficient, any hypothesis that the NUG coefficient is greater can be rejected with even more certainty. Table C7 presents these results.

Table C7. Test for Equality of the NUG and C Coefficients

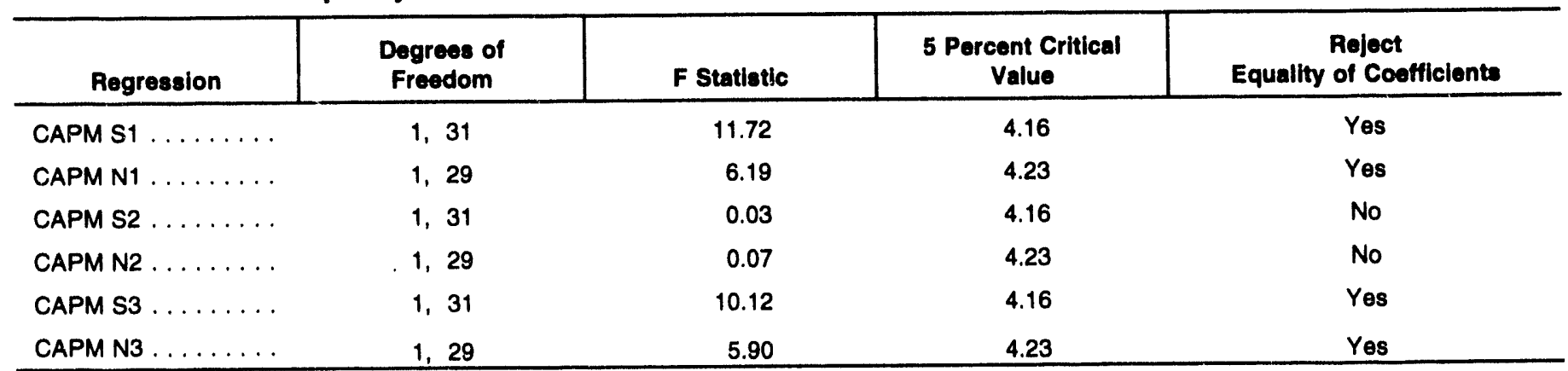




\section{DCF}

The DCF specification (Table C8) performs poorly. Other than the intercepts, only two of the eighteen coefficients have a t-statistic greater than 2 , and these are both on $C$. This is approximately what one would expect from chance, though there may be a weak indication that $C$ is positive and has a stronger impact than NUG.

One interesting coefficient in the DCF specification is on the NUG variable in case S2. This result may also be driven by the data of the outlier firm, i.e., CMS. As the discussion of Table $\mathrm{C} 1$ indicated, Consumers Power has a significant NUG equivalent debt even after adjusting for risk using the Standard and Poor's risk factors. CMS, the parent of Consumers Power, is a company for which a high proxy value for $r_{e}$ is used. SCE, on the other hand, has a high NUG value in the S1 case, but a much lower value in the S2 case. Its $r_{e}$ is in the middle range. Therefore, the change in significance for the NUG variable between $\mathrm{S} 1$ and $\mathrm{S} 2$ seems largely due to CMS.
EPR

The EPR specification (Table C9) resembles the DCF results. The coefficients for Debt/Equity are closer to significance than for DCF. Again, besides the intercept, there are only two significant coefficients; the same as in Table C8. Also, case S2 produces the most positive value for NUG.

Table C9 also shows some interesting differences between the $\mathrm{N}$ and the $\mathrm{S}$ versions regarding the $\mathrm{t}$-statistics on the $\mathrm{C}$ variable. Although none of the $\mathrm{N}$ case coefficients are significant, there is much better performance in these cases than in the $S$ versions. This is due again to CMS, which has very high values of $r_{e}$ and $C$. When these are removed, a more clearly negative relationship begins to emerge between $C$ and EPR. This is explained next in more detail by performing an additional test which will help elucidate the basic question.

Table C8. Discounted Cash Flow Model Regression Results

\begin{tabular}{|c|c|c|c|c|c|c|}
\hline & s1 & N1 & S2 & N2 & S3 & N3 \\
\hline$\ldots \ldots \ldots$ & $\begin{array}{r}0.0687 \\
(8.22)\end{array}$ & $\begin{array}{c}0.0782 \\
(8.36)\end{array}$ & $\begin{array}{c}0.0744 \\
(8.78)\end{array}$ & $\begin{array}{c}0.0793 \\
(8.61)\end{array}$ & $\begin{array}{c}0.0685 \\
(8.59)\end{array}$ & $\begin{array}{r}0.0757 \\
(8.51)\end{array}$ \\
\hline Debt/Equity ... & $\begin{array}{c}0.0104 \\
(1.39)\end{array}$ & $\begin{array}{l}0.0119 \\
(1.63)\end{array}$ & $\begin{array}{l}0.0104 \\
(1.48)\end{array}$ & $\begin{array}{c}0.0112 \\
(1.57)\end{array}$ & $\begin{array}{l}0.0112 \\
(1.56)\end{array}$ & $\begin{array}{c}0.0116 \\
(1.64)\end{array}$ \\
\hline NUG & $\begin{array}{c}0.0040 \\
(0.33)\end{array}$ & $\begin{array}{c}0.0073 \\
(0.61)\end{array}$ & $\begin{array}{l}0.1820 \\
(1.91)\end{array}$ & $\begin{array}{c}0.1324 \\
(1.26)\end{array}$ & $\begin{array}{c}0.0490 \\
(1.71)\end{array}$ & $\begin{array}{l}0.0641 \\
(1.83)\end{array}$ \\
\hline$c \ldots \ldots$ & $\begin{array}{c}0.0559 \\
(2.25)\end{array}$ & $\begin{array}{l}0.0131 \\
(0.41)\end{array}$ & $\begin{array}{l}0.0236 \\
(0.84)\end{array}$ & $\begin{array}{c}0.0062 \\
(0.02)\end{array}$ & $\begin{array}{l}0.0470 \\
(2.10)\end{array}$ & $\begin{array}{c}0.0171 \\
(0.61)\end{array}$ \\
\hline Adjusted $\mathrm{R}^{2} \ldots \ldots \ldots$ & 0.21 & 0.04 & 0.29 & 0.08 & 0.27 & 0.13 \\
\hline
\end{tabular}

Table C9. Regression Results of Earnings-Price Ratio Model

\begin{tabular}{|c|c|c|c|c|c|c|}
\hline & s1 & N1 & s2 & N2 & S3 & N3 \\
\hline Intercept . & $\begin{array}{l}0.0577 \\
(5.23)\end{array}$ & $\begin{array}{l}0.0725 \\
(6.05)\end{array}$ & $\begin{array}{l}0.0669 \\
(6.12)\end{array}$ & $\begin{array}{l}0.0737 \\
(6.23)\end{array}$ & $\begin{array}{c}0.0569 \\
(5.23)\end{array}$ & $\begin{array}{c}0.0690 \\
(5.70)\end{array}$ \\
\hline DebvEquity & $\begin{array}{l}0.0171 \\
(1.73)\end{array}$ & $\begin{array}{l}0.0195 \\
(2.09)\end{array}$ & $\begin{array}{l}0.0168 \\
(1.83)\end{array}$ & $\begin{array}{l}0.0181 \\
(1.97)\end{array}$ & $\begin{array}{c}0.0175 \\
(1.79)\end{array}$ & $\begin{array}{c}0.0189 \\
(1.99)\end{array}$ \\
\hline NUG & $\begin{array}{l}0.0170 \\
(1.08)\end{array}$ & $\begin{array}{c}0.0217 \\
(1.41)\end{array}$ & $\begin{array}{l}0.3113 \\
(2.54)\end{array}$ & $\begin{array}{l}0.2354 \\
(1.74)\end{array}$ & $\begin{array}{l}0.0541 \\
(1.39)\end{array}$ & $\begin{array}{l}0.0529 \\
(1.11)\end{array}$ \\
\hline$c \ldots \ldots \ldots \ldots \ldots$ & $\begin{array}{c}0.0068 \\
(0.19)\end{array}$ & $\begin{array}{c}-0.0611 \\
(-1.49)\end{array}$ & $\begin{array}{c}-0.0393 \\
(-1.08)\end{array}$ & $\begin{array}{r}-0.0641 \\
(-1.60)\end{array}$ & $\begin{array}{c}0.0083 \\
(0.27)\end{array}$ & $\begin{array}{c}-0.0412 \\
(-1.07)\end{array}$ \\
\hline Adjusted $R^{2} \ldots \ldots \ldots$ & 0.07 & 0.09 & 0.20 & 0.12 & 0.09 & 0.07 \\
\hline
\end{tabular}




\section{Special Interpretation of the Earnings-Price Ratio}

Careful examination of Table C9 shows that the inclusion of CMS introduces a potentially spurious correlation between EPR and the $C$ variable. One reason why CMS has a high value for the projected construction expenses variable, $C$, is that construction expenses have been normalized by the market value of the firm's equity. Its market value of equity is relatively low. If extreme cases are removed from the sample and the equation is re-estimated without them, the results may be more meaningful.

Table C10 summarizes the results of such cases, which are designated by $\mathrm{L}$. CMS and Niagara Mohawk, have been eliminated from the sample, since these proxy values were used for $r_{e}$.

Table C10 shows a negative coefficient on C in the EPR model regression. As noted previously, this probably does not indicate that $C$ reduces the cost of equity capital, because EPR ignores earnings growth, for which $C$ may be a reasonably good proxy. This does not make the result uninteresting, but does suggest a closer look at the mechanisms involved. EPR is evaluated as a measure of $r_{e}$.

As noted earlier, when EPR was developed as a measure of $r_{e}$, it was the same as the DCF model formulation but with the growth in dividends-g, assumed to be exactly the ratio of retained earnings to the market value or price, i.e., RE/P. This assumption is at best an approximation, but when $C$ is included it becomes a serious misspecification. $C$ could be correlated with the difference between dividend growth and the ratio of retained earnings to price. Thus the EPR model does not pick up one of the main ways in which $C$ affects $r_{e}$. To interpret the results of the EPR regression, some additional information can be supplied by both the DCF regressions, and the CAPM regressions.
The DCF regressions indicate that $C$ has essentially no effect on $r_{e}$, or more precisely no effect on the sum of earnings to price ratio and the difference between the dividend growth rate and the ratio of earnings to price. ${ }^{157}$ However, the EPR regressions indicate that C has a negative impact on the earnings to price ratio. Obviously, the difference between these two results can be explained by the unobserved effect on the difference between the dividend growth rate and the ratio of retained earnings to price. Clearly, this must be a positive effect in order to cancel C's negative effect on the earning to price ratio and produce no net effect in the DCF model estimation for $R_{e}$. The correct interpretation of the effect of $C$ on the earnings to price ratio appears to be that an increase in $C$ causes both a decrease in the earnings-price ratio and an increase in the difference between dividend growth and the ratio of retained earnings to price. Or, more to the point, $C$ does not affect $r_{e}$, but it does lead to the expectation that dividend growth will be greater than the ratio of retained earnings to price, which occurs only if the return on capital is greater than the cost of capital.

There is a slight indication in two DCF regressions that the $C$ coefficient is positive, and the CAPM regressions give a strong positive correlation. Therefore, it should be checked whether or not this would change the interpretation. In fact, it does not; it only reinforces it. If $C$ causes $\mathrm{E} / \mathrm{P}+(\mathrm{g}-\mathrm{RE} / \mathrm{P})$ to go up but $\mathrm{E} / \mathrm{P}$ to go down, then its impact on $(\mathrm{g}-\mathrm{RE} / \mathrm{P})$ must be even more positive than initially considered.

The results are less conclusive regarding NUG, it appears to have a positive coefficient in the EPR regression and a slightly smaller, but still positive coefficient in the DCF regression. These results are so weak as to be almost not worth the bother of interpretation, but if true, they indicate that NUG has a positive effect on the earnings to price ratio and causes a very weak reduction in expected earnings growth. The combination of these two appears to result in a small increase in the cost of equity capital.

Table C10. Earnings-Price Ratio without Proxy Cost Firms

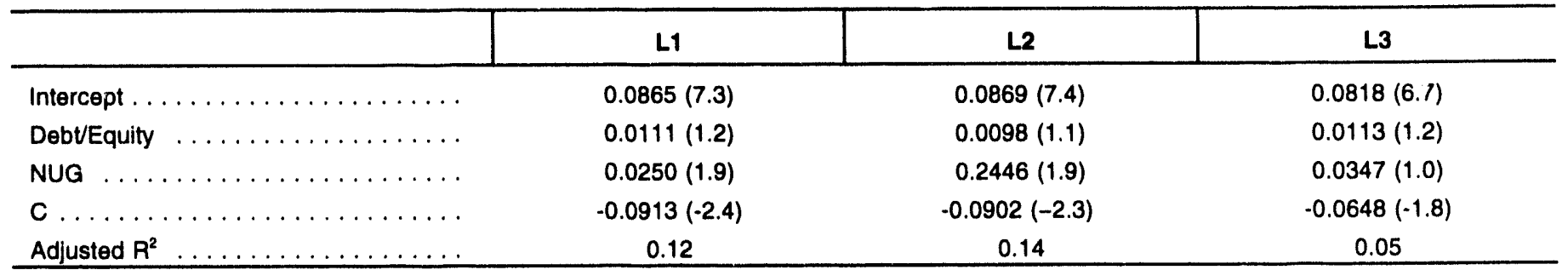

\footnotetext{
${ }^{157}$ Recall that the DCF estimator has the following form $r_{e}=D / P+g$. The terms on the right can be reformulated as: $D / P+[R E / P$ $+(\mathrm{g}-\mathrm{RE} / \mathrm{P})]=\mathrm{E} / \mathrm{P}+(\mathrm{g}-\mathrm{RE} / \mathrm{P})$.
} 
Before leaving the interpretation of the EPR results, it is worth examining the underlying economic mechanism. The most straightforward explanation is based on construction being undertaken when a utility finds an opportunity to make a return that is above the cost of capital. ' $n$ this case, one can expect earnings-pershare to increase in the future when the project is brought on line. This increases the present value of the stream of expected future earnings without increasing current earnings. Since stock price, $P$, reflects the present value of expected earnings, it will increase and earnings price ratio will decrease. This explains the negative coefficient for $C$ in the EPR regression. Since the decrease in earnings to price ratio is exactly canceled by the increase in the expected growth of earnings, these two effects explain the insignificant $C$ coefficient in the DCF equation.

\section{Regression Results for Expanded Model}

There are two reasons to include variables whose coefficients are not of interest. The first is to avoid the classic "omitted variable" problem which biases the coefficients of interest, and the second is to reduce the variance of the error term and thereby reduce the standard errors of the coefficients of interest.

The omitted variable problem occurs when a causal variable which is correlated with an included independent variable is omitted from the regression. In this case, the included variable picks up some of the significance that should rightly be attributed to the omitted variable.

There is also a possible reason for not including an independent variable that is not causal. If such a variable is correlated with an independent variable of interest it will erroneously increase the standard error of the variable of interest.

As mentioned earlier in this Appendix, previous studies have identified fuel mix and "regulatory climate" as among the more important sources of variation. This analysis used the ratio of nuclear assets to total electric utility plant as a proxy for fuel mix, and Merrill Lynch's rating of State public utility commissions as a proxy for "regulatory climate." Inclusion of these variables permitted specification of the expanded model as discussed in the preceding sections and led to the following changes in the CAPM regression statistics (Tables C11 through C14):

1. The adjusted $R^{2}$ decreases for all six regressions.

2. The $D / E$ coefficient decreases slightly for all six regressions.

3. The NUG coefficient increases slightly in four of six regressions.

4. The $C$ coefficient increases in magnitude slightly for all six regressions.

5. The t-statistics get slightly worse on all 18 coefficients.

Two of these outcomes are particularly telling. First, the fact that adjusted $R^{2}$ decreased indicates that the two "omitted" variables together provided less new explanatory power than one would expect from two randomly generated $X$ variables. In other words, they could not have performed worse. This rules out the possibility that these variables should be adopted for the second reason, to decrease standard errors.

Second, the fact that the $C$ coefficient increases in magnitude indicates that the standard omitted variables problem cannot be at work here. Therefore, the increase in the standard error of the CWIP coefficients comes from a small colinearity problem contributed by the new variables. The NUG coefficient behaves less consistently. Four times out of six it increases; it remains unchanged once, and decreases once. Measured in absolute terms or in standard error, the largest of these changes is the decrease. Thus, if the addition of the new variables is correcting a bias, it does this so poorly that it is not clear in which direction the correction is being made. Again, there is virtually no evidence for an omitted variable problem. The Debt/Equity variable is the only one with a coefficient that behaves as if NUKE and PUC were correlated, causal omitted variables, although the effect is not particularly strong-the coefficient changes by about one-half standard error or less. In the DCF regressions, five out of six times the coefficient increases. Again, there is little if any reason to believe that anything of statistical significance is happening, especially given the fact that the $D / E$ is the variable with the strongest theoretical backing.

\section{Data}

Tables $\mathrm{C} 15$ through $\mathrm{C} 20$ contain data used in the regression analysis. 
Table C11. Capital Asset Pricing Model Results

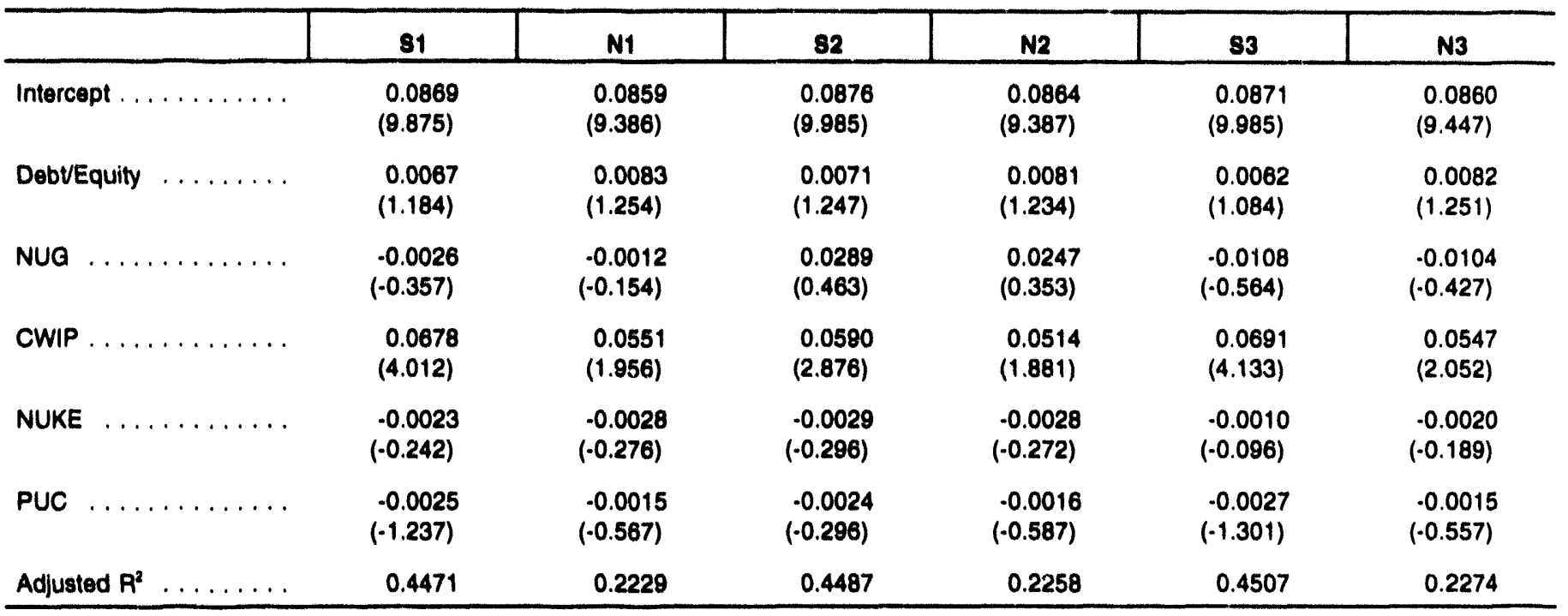

Table C12. Dlscounted Cash Flow Results

\begin{tabular}{|c|c|c|c|c|c|c|}
\hline & $\mathbf{8 1}$ & N1 & $\mathbf{s 2}$ & N2 & s3 & N3 \\
\hline Intercept . . . . . . . & $\begin{array}{c}0.0688 \\
(4.643)\end{array}$ & $\begin{array}{c}0.0633 \\
(4.532)\end{array}$ & $\begin{array}{c}0.0708 \\
(5.060)\end{array}$ & $\begin{array}{c}0.0651 \\
(4.692)\end{array}$ & $\begin{array}{c}0.0689 \\
(4.891)\end{array}$ & $\begin{array}{r}0.0627 \\
(4.738)\end{array}$ \\
\hline Debt/Equity $\ldots \ldots \ldots$ & $\begin{array}{r}0.0010 \\
(1.024)\end{array}$ & $\begin{array}{c}0.0214 \\
(2.126)\end{array}$ & $\begin{array}{c}0.0116 \\
(1.279)\end{array}$ & $\begin{array}{r}0.0200 \\
(2.014)\end{array}$ & $\begin{array}{c}0.0124 \\
(1338)\end{array}$ & $\begin{array}{r}0.0217 \\
(2.278)\end{array}$ \\
\hline NUG $\ldots \ldots \ldots$ & $\begin{array}{c}0.0039 \\
(0.313)\end{array}$ & $\begin{array}{c}0.0079 \\
(0.660)\end{array}$ & $\begin{array}{c}0.1872 \\
(1.879)\end{array}$ & $\begin{array}{c}0.1220 \\
(1.159)\end{array}$ & $\begin{array}{c}0.0516 \\
(1.674)\end{array}$ & $\begin{array}{r}0.0656 \\
(1.847)\end{array}$ \\
\hline CWIP $\ldots \ldots \ldots \ldots$ & $\begin{array}{r}0.0577 \\
(2.030)\end{array}$ & $\begin{array}{l}-0.0275 \\
(-0.639)\end{array}$ & $\begin{array}{c}0.0207 \\
(0.632)\end{array}$ & $\begin{array}{c}-0.0294 \\
(-0.715)\end{array}$ & $\begin{array}{r}0.0434 \\
(1.610)\end{array}$ & $\begin{array}{r}-0.0249 \\
(-0.642)\end{array}$ \\
\hline NUKE $\ldots \ldots \ldots \ldots$ & $\begin{array}{c}0.0026 \\
(0.157)\end{array}$ & $\begin{array}{c}-0.0043 \\
(-0.275)\end{array}$ & $\begin{array}{c}0.0011 \\
(0.072)\end{array}$ & $\begin{array}{c}-0.0032 \\
(-0.207)\end{array}$ & $\begin{array}{c}-0.0048 \\
(-0.297)\end{array}$ & $\begin{array}{r}-0.0097 \\
(-0.638)\end{array}$ \\
\hline PUC $\ldots \ldots \ldots \ldots$ & $\begin{array}{c}-0.0002 \\
(-0.060)\end{array}$ & $\begin{array}{c}0.0062 \\
(1.514)\end{array}$ & $\begin{array}{c}0.0010 \\
(0.306)\end{array}$ & $\begin{array}{c}0.0058 \\
(1.432)\end{array}$ & $\begin{array}{c}0.0002 \\
(0.073)\end{array}$ & $\begin{array}{r}0.0061 \\
(1.542)\end{array}$ \\
\hline
\end{tabular}


Table C13. Earnings-Price Ratio Results

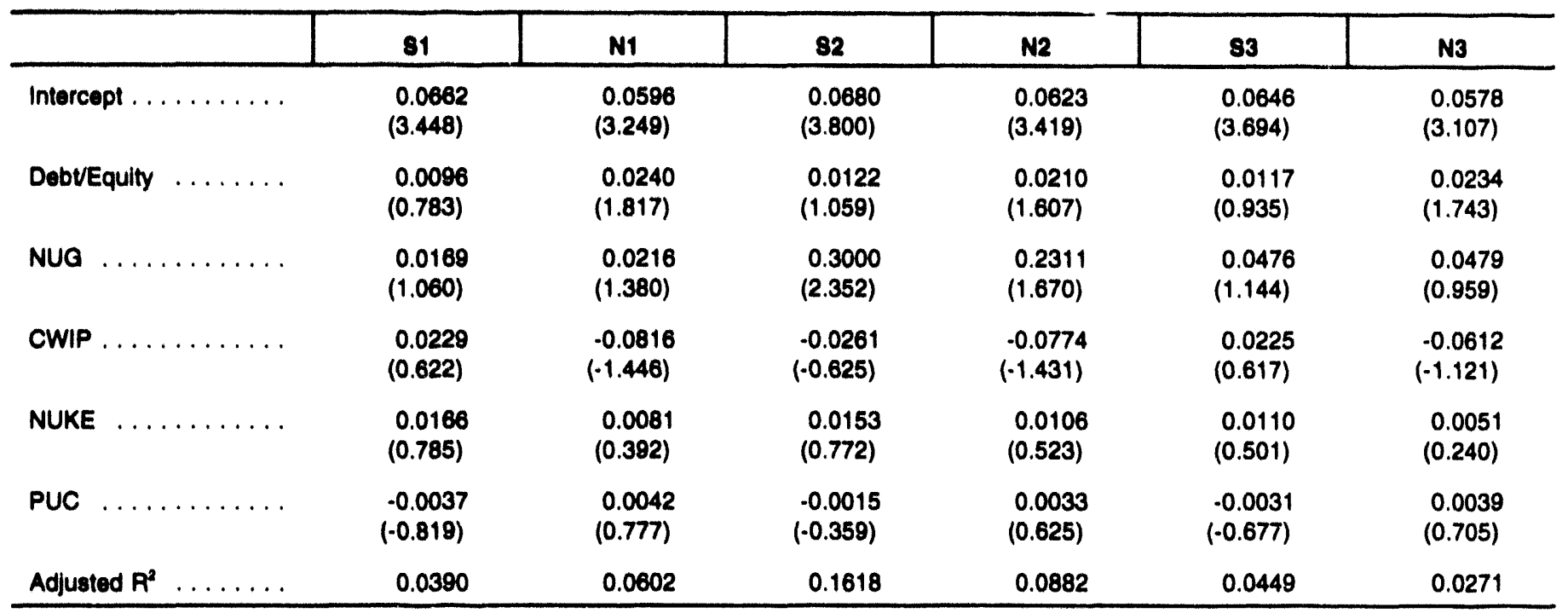

Table C14. Adjusted $R^{2}$ for 3 and 5 Variable Specifications

\begin{tabular}{ccccc}
\hline & Case & 3 Variables & 5 Variables \\
\hline CAPM $\ldots \ldots \ldots \ldots \ldots \ldots$ & S1 & N1 & 0.4521 & 0.4471 \\
& S2 & 0.2632 & 0.2229 \\
& N2 & 0.4562 & 0.2258 \\
& S3 & 0.2653 & 0.4507 \\
& N3 & 0.4543 & 0.2274 \\
& & 0.2697 & 0.1514 \\
& S1 & & 0.0482 \\
& N1 & 0.2054 & 0.2409 \\
& S2 & 0.0385 & 0.0787 \\
& N2 & 0.2872 & 0.2235 \\
& S3 & 0.0766 & 0.1413 \\
& N3 & 0.2714 & 0.0390 \\
& S1 & 0.1273 & 0.0602 \\
& N1 & S2 & 0.0664 & 0.1618
\end{tabular}


\& Table C15. Cost of Capital Variables

\begin{tabular}{|c|c|c|c|c|c|c|c|c|c|c|c|c|c|c|}
\hline Company & Beta & $\begin{array}{c}\text { Risk Free } \\
\text { Return } \\
\text { (percent) }\end{array}$ & $\begin{array}{c}\text { Market } \\
\text { Return } \\
\text { (percent) }\end{array}$ & $\begin{array}{l}\text { CAPM" } \\
\text { Unad- } \\
\text { justed }\end{array}$ & $\begin{array}{c}\text { CAPM" } \\
\text { Adjusted }\end{array}$ & $\begin{array}{c}\begin{array}{c}\text { Dividend } \\
\text { Yield } \\
\text { (percent) }\end{array} \\
\end{array}$ & $\begin{array}{c}\text { Dividend } \\
\text { Growth } \\
\text { (percent) }\end{array}$ & $\begin{array}{c}\text { DCF } \\
\text { Unad- } \\
\text { justed } \\
\text { (percent) }\end{array}$ & $\begin{array}{c}\text { DCF } \\
\text { Adjusted } \\
\text { (percent) }\end{array}$ & $\begin{array}{c}92 \\
\text { EPS }^{c}\end{array}$ & $\begin{array}{c}93 \\
\text { EPS }^{c}\end{array}$ & $\begin{array}{c}12 / 92 \\
\mathrm{MN}^{4}\end{array}$ & $\begin{array}{c}\text { EPP } \\
\text { Unad } \\
\text { justed }\end{array}$ & $\begin{array}{c}\text { E/PE } \\
\text { Adt- } \\
\text { justed }\end{array}$ \\
\hline Atlantic Energy Inc. & 0.65 & 4.50 & 12.90 & 0.100 & 0.100 & 6.70 & 1.50 & 8.20 & 8.20 & 1.67 & 1.75 & 23.13 & 0.074 & \\
\hline AEP $\ldots \ldots \ldots$ & 0.75 & 4.50 & 12.90 & 0.108 & 0.108 & 7.50 & 1.00 & 8.50 & 8.50 & 2.54 & 2.75 & 33.13 & 0.080 & 0.080 \\
\hline Baltimore Gas \& Electric...$\ldots$ & 0.71 & 4.50 & 12.90 & 0.105 & 0.105 & 6.30 & 3.00 & 9.30 & 9.30 & 1.63 & 1.80 & 23.00 & 0.075 & 0.075 \\
\hline Boston Edison Company & 0.65 & 4.50 & 12.90 & 0.100 & 0.100 & 6.30 & 4.00 & 10.30 & 10.30 & 2.10 & 2.20 & 27.50 & 0.078 & 0.078 \\
\hline Carolina Power \& Light . & 0.65 & 4.50 & 12.90 & 0.100 & 0.100 & 6.10 & 4.00 & 10.10 & 10.10 & 2.36 & 2.30 & 27.75 & 0.084 & 0.084 \\
\hline Centerior $\ldots \ldots \ldots$ & 0.69 & 4.50 & 12.90 & 0.103 & 0.103 & 8.00 & 1.00 & 9.00 & 9.00 & 1.50 & 1.85 & 19.88 & 0.084 & 0.084 \\
\hline Central Power \& Light .... & 0.57 & 4.50 & 12.90 & 0.093 & 0.093 & 5.30 & 5.00 & 10.30 & 10.30 & 2.00 & 2.15 & 29.00 & 0.072 & 0.072 \\
\hline Cincinnati Gas \& Electric Company & 0.77 & 4.50 & 12.90 & 0.110 & 0.110 & 7.00 & 2.00 & 9.00 & 9.00 & 2.04 & 2.15 & 24.00 & 0.087 & 0.087 \\
\hline CMS Energy ........ & 0.73 & 4.50 & 12.90 & 0.106 & 0.137 & 2.50 & na & 2.50 & 13.86 & -3.72 & 1.25 & 18.38 & 0.000 & 0.117 \\
\hline Con Edison & 0.74 & 4.50 & 12.90 & 0.107 & 0.107 & 6.30 & 3.00 & 9.30 & 9.30 & 2.46 & 2.55 & 31.00 & 0.081 & 0.081 \\
\hline Derroit Edison $\ldots \ldots \ldots \ldots \ldots$ & 0.64 & 4.50 & 12.90 & 0.099 & 0.099 & 6.30 & 4.00 & 10.30 & 10.30 & 3.79 & 3.20 & 33.00 & 0.106 & 0.106 \\
\hline Dominion Resources, Inc. & 0.55 & 4.50 & 12.90 & 0.091 & 0.091 & 6.40 & 3.00 & 9.40 & 9.40 & 2.76 & 3.05 & 39.50 & 0.074 & 0.074 \\
\hline DPL . & 0.55 & 4.50 & 12.90 & 0.091 & 0.091 & 5.90 & 3.00 & 8.90 & 8.90 & 1.34 & 1.50 & 19.75 & 0.072 & 0.072 \\
\hline Duke Power...$\ldots \ldots$ & 0.66 & 4.50 & 12.90 & 0.100 & 0.100 & 5.10 & 4.00 & 9.10 & 9.10 & 2.21 & 2.50 & 36.13 & 0.065 & 0.065 \\
\hline Florida Progress Corporation & 0.67 & 4.50 & 12.90 & 0.101 & 0.101 & 6.10 & 3.00 & 9.10 & 9.10 & 2.06 & 2.35 & 32.63 & 0.068 & 0.068 \\
\hline FPL Group $\ldots \ldots \ldots \ldots$ & 0.77 & 4.50 & 12.90 & 0.110 & 0.110 & 6.90 & 2.00 & 8.90 & 8.90 & 2.65 & 2.75 & 36.25 & 0.074 & 0.074 \\
\hline General Public Utilities & 0.58 & 4.50 & 12.90 & 0.094 & 0.094 & 6.60 & 6.00 & 12.60 & 12.60 & 2.27 & 2.50 & 27.63 & 0.086 & 0.086 \\
\hline Houston Lighting \& Power & 0.60 & 4.50 & $1 ? .90$ & 0.095 & 0.095 & 6.50 & 2.00 & 8.50 & 8.50 & 3.36 & 3.50 & 45.88 & 0.075 & 0.075 \\
\hline Kansas City Power \& Light & 0.67 & 4.50 & 12.90 & 0.101 & 0.101 & 6.40 & 2.00 & 8.40 & 8.40 & 1.35 & 1.70 & 22.75 & 0.067 & 0.067 \\
\hline New England Electric $\ldots \ldots \ldots \ldots$ & 0.74 & 4.50 & 12.90 & 0.107 & 0.107 & 6.00 & 2.00 & 8.00 & 8.00 & 2.85 & 2.90 & 38.50 & 0.075 & 0.075 \\
\hline Niagara Mohawk Power ... & 0.65 & 4.50 & 12.90 & 0.100 & 0.137 & 4.80 & na & 4.80 & 13.86 & 1.61 & 1.75 & 19.13 & 0.088 & 0.117 \\
\hline NYSEG $\ldots \ldots \ldots \ldots \ldots \ldots$ & 0.69 & 4.50 & 12.90 & 0.103 & 0.103 & 7.00 & 1.00 & 8.00 & 8.00 & 2.40 & 2.55 & 31.00 & 0.080 & 0.080 \\
\hline Northem States Power & 0.75 & 4.50 & 12.90 & 0.108 & 0.108 & 6.00 & 4.00 & 10.00 & 10.0 & 3.04 & 3.20 & 43.25 & 0.072 & 0.072 \\
\hline Ohio Edison $\ldots \ldots \ldots \ldots \ldots$ & 0.80 & 4.50 & 12.90 & 0.112 & 0.112 & 6.50 & 2.00 & 8.50 & 8.50 & 1.70 & 1.60 & 23.13 & 0.071 & 0.071 \\
\hline Pacific Gas \& Electric & 0.65 & 4.50 & 12.90 & 0.100 & 0.100 & 5.80 & 5.00 & 10.80 & 10.8 & 2.58 & 2.70 & 32.00 & 0.083 & 0.083 \\
\hline Pacificorp & 0.59 & 4.50 & 12.90 & 0.095 & 0.095 & 8.10 & 0.00 & 8.10 & 8.10 & -1.42 & 1.60 & 19.00 & 0.005 & 0.005 \\
\hline Pennsytvania Power \& Light & 0.71 & 4.50 & 12.90 & 0.105 & 0.105 & 6.00 & 3.00 & 9.00 & 9.00 & 2.02 & 2.10 & 27.25 & 0.076 & 0.076 \\
\hline Portland General Corporation & 0.95 & 4.50 & 12.90 & 0.125 & 0.125 & 6.40 & 4.00 & 10.40 & 10.4 & 1.93 & 1.80 & 18.38 & 0.101 & 0.101 \\
\hline Potomac Electric Power Company & 0.74 & 4.50 & 12.90 & 0.107 & 0.107 & 6.80 & 2.00 & 8.80 & 8.80 & 1.80 & 1.85 & 24.00 & 0.076 & 0.076 \\
\hline San Diego Gas \& Electric & 0.60 & 4.50 & 12.90 & 0.095 & 0.095 & 6.10 & 2.50 & 8.60 & 8.60 & 1.77 & 1.85 & 24.00 & 0.075 & 0.075 \\
\hline Southem $\ldots \ldots \ldots \ldots \ldots$ & 0.67 & 4.50 & 12.90 & 0.101 & 0.101 & 6.20 & 3.00 & 9.20 & 9.20 & 3.02 & 3.10 & 38.50 & 0.079 & 0.079 \\
\hline SCE Corp & 0.66 & 4.50 & 12.90 & 0.100 & 0.100 & 6.50 & 3.00 & 9.50 & 9.50 & 3.32 & 3.65 & 44.00 & 0.079 & 0.079 \\
\hline Texas Utilities . . . . . . . & 0.67 & 4.50 & 12.90 & 0.101 & 0.101 & 7.10 & 1.00 & 8.10 & 8.10 & 3.26 & 3.55 & 43.00 & 0.079 & 0.079 \\
\hline Union Electric Company $\ldots \ldots \ldots$ & 0.58 & 4.50 & 12.90 & 0.094 & 0.094 & 6.30 & 2.00 & 8.30 & 8.30 & 2.83 & 2.80 & 37.00 & 0.076 & 0.076 \\
\hline WI Energy Corporation & 0.66 & 4.50 & 12.90 & 0.100 & 0.100 & 5.20 & 5.00 & 10.20 & 10.20 & 1.67 & 1.90 & 26.50 & 0.067 & \\
\hline
\end{tabular}

CAPM is the Capital Asset Pricing Model.

'DCF is Discounted Cash Flow.

'EPS is Eamings Per Share.

QMV is Market Value.

'E/P is the Eamings/Price Ratio.

Notes: Shaded areas indicate imputed values for CMS Energy and SCE Corp. as discussed in the text. All data in boxes are attributable to Value Line, Investor Survey newsletter.

Sources: Beta and outlined data, Dividend Growth except outlined data-Merrill Lynch's U.S. Company and ADR Statistics, The Global Research Review (February 1993). pp. 80-85: 1992 EPS and mV,

except for data in boxes-1992 Annual Reports Dividend Yield. 


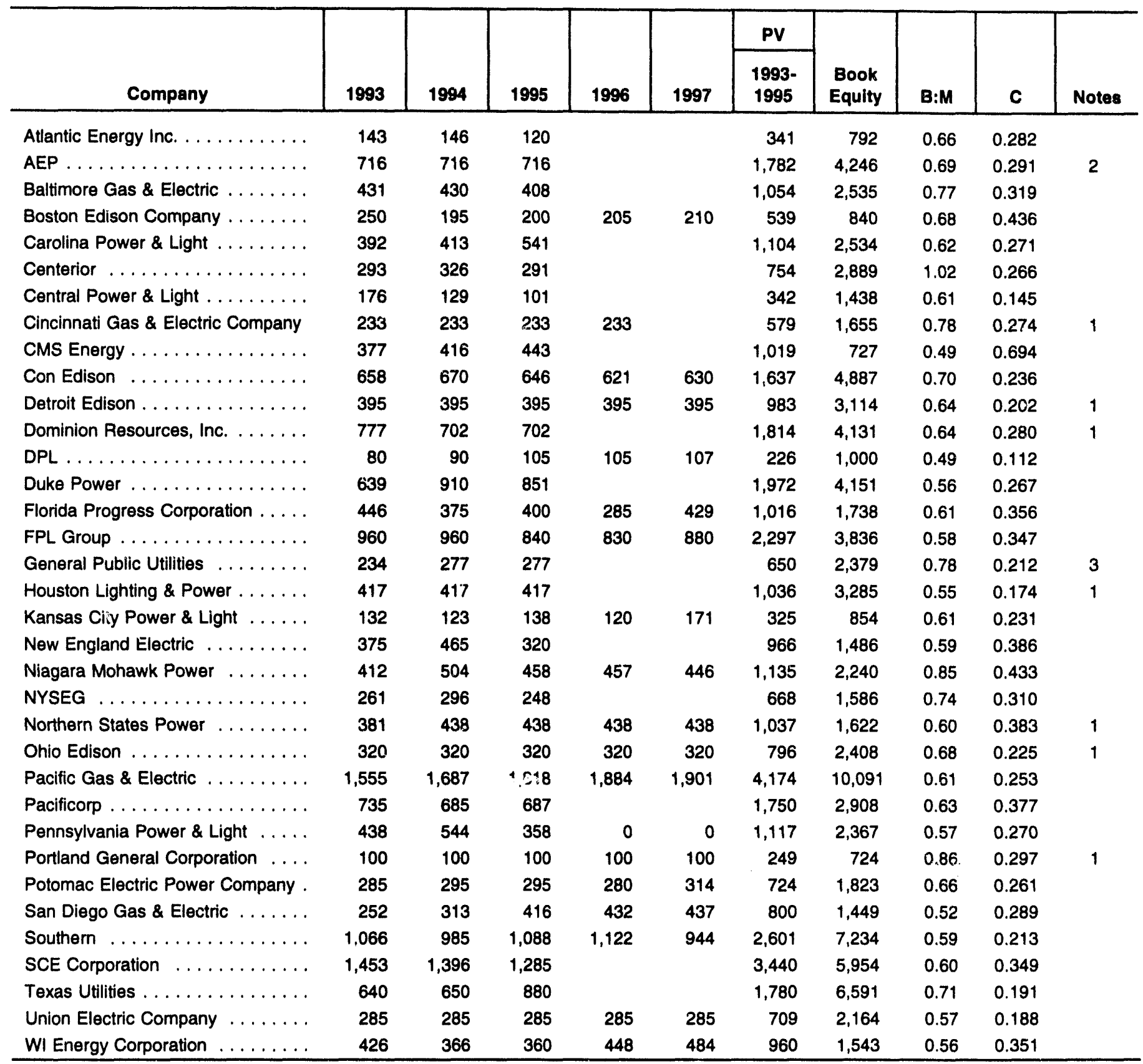

Notes: 1 = values were given in the aggregate; annual \#'s obtained by evenly prorating. 2 = only a value for 1993 provided; used 1993 value for 1994 and 1995. $3=$ only a value for 1993 \& 1994 provided; used 1994 value for 1995 .

$\mathrm{PV}=$ Present value.

$B: M=$ Book to market value.

$C=$ Projections of capital expenditures.

Source: Securities Exchange Commission, Form 10-K, "Annual Report Pursuant to Section 13 or 15(d) of the Securities Exchange Act of $1934^{n}$-individual utility submissions. 
Table C17. Input Variables Used to Construct D/E and NUG 1,2,3

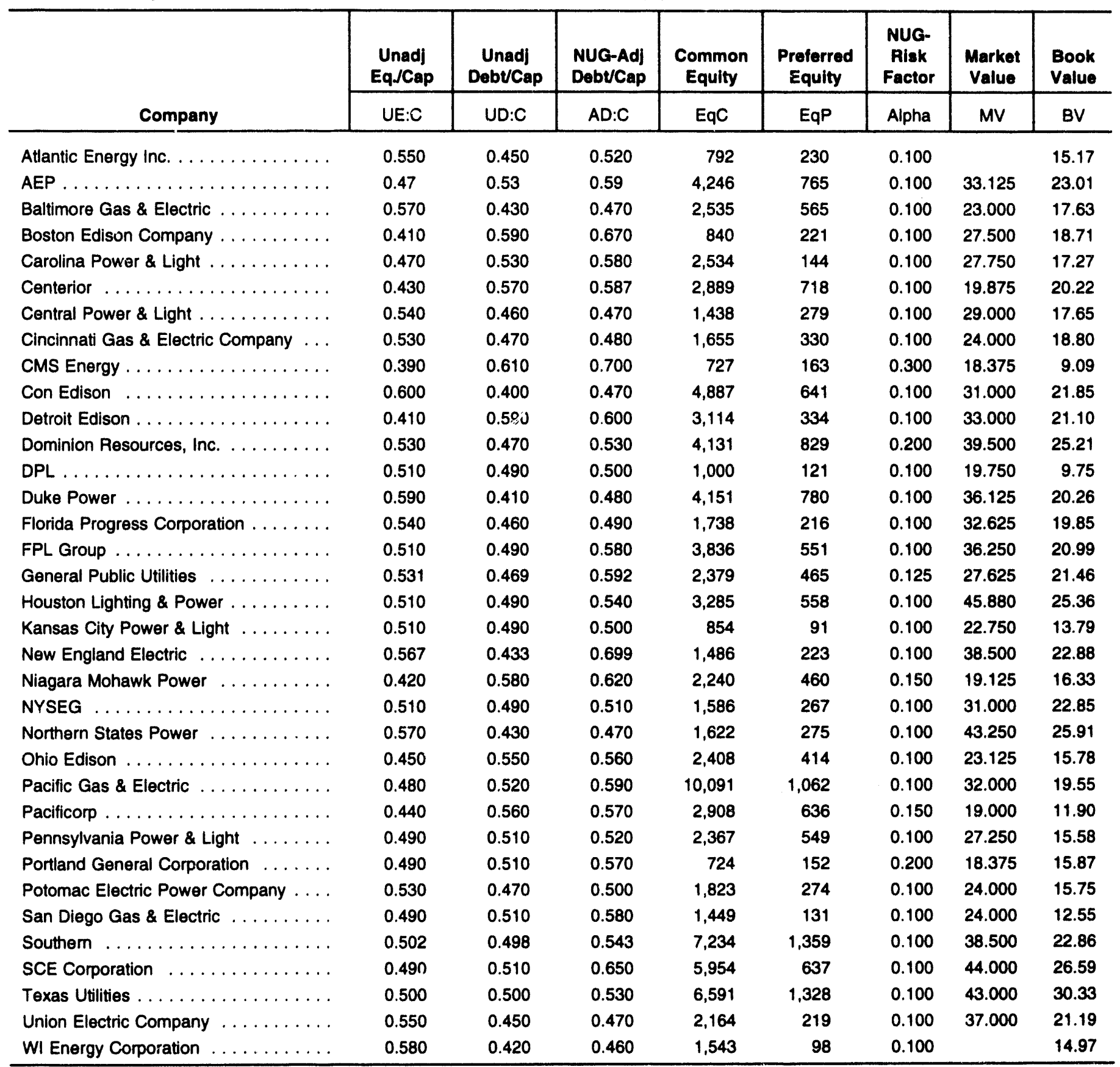

Sources: Merrill Lynch's U.S. Company and ADR Statistics, The Global Research Review (February 1993), pp. 80-85. Value Line, Investor Survey newsletter. Securities Exchange Commission, Form 10-K, "Annual Report Pursuant to Section 13 or 15(d) of the Securities Exchange Act of 1934"-individual utility submissions. 
Table C18. Intermediate Variables (1): D/E and NUG 1,2,3

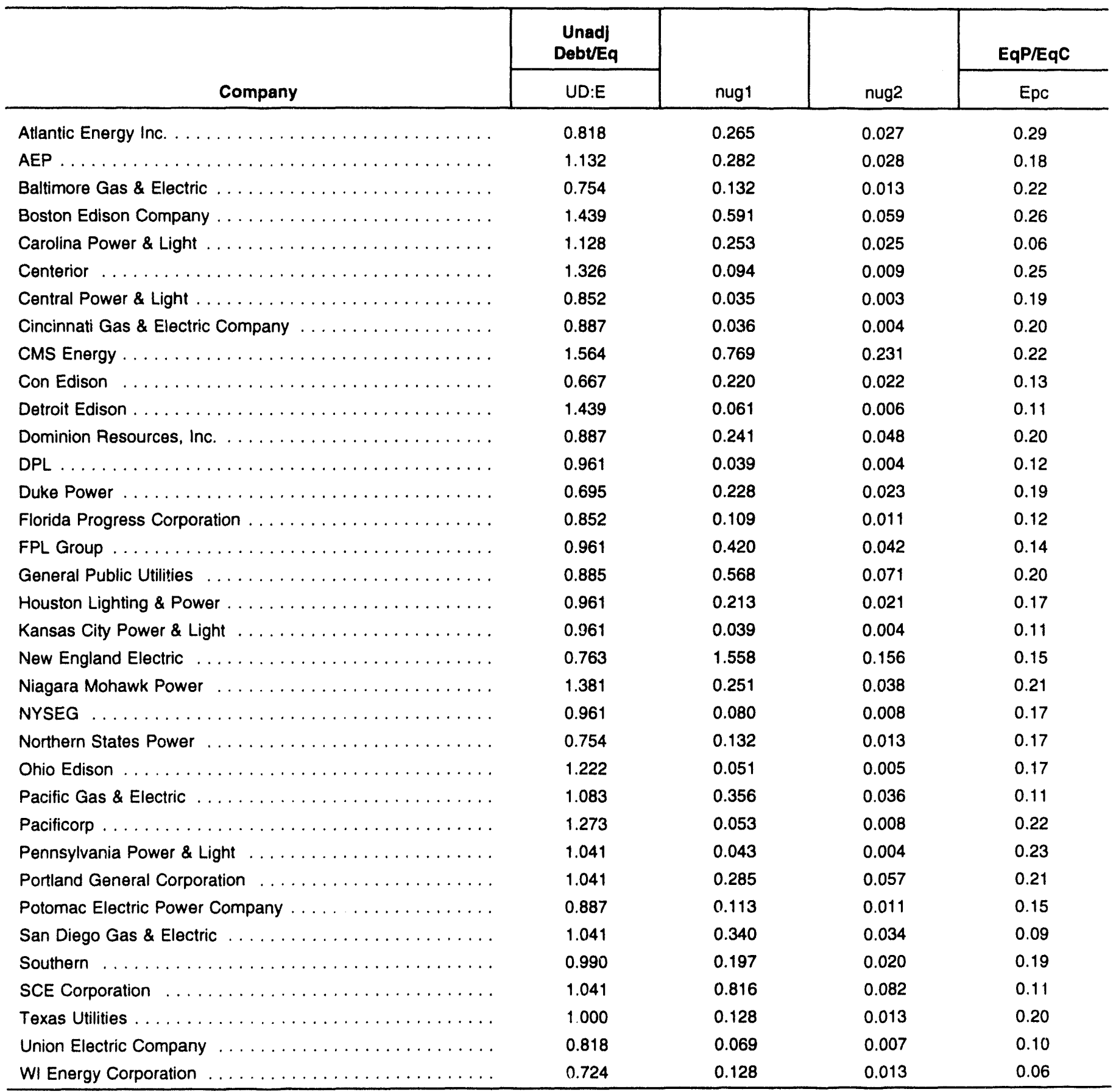

Sources: Merrill Lynch's U.S. Company and ADR Statistics, The Global Research Review (February 1993), pp. 80-85. Value Line, Investor Survey newsletter. Securities Exchange Commission, Form 10-K, "Annual Report Pursuant to Section 13 or 15(d) of the Securities Exchange Act of $1934^{n}$-individual utility submissions. 
Table C19. Intermediate Variables (2): D/E and NUG 1,2,3

\begin{tabular}{|c|c|c|c|c|}
\hline \multirow[b]{3}{*}{ Company } & \multirow[b]{2}{*}{ DebtEqC } & \multicolumn{3}{|c|}{ X/Common Book Equity } \\
\hline & & $\begin{array}{l}\text { nug1/ } \\
\text { EqC }\end{array}$ & $\begin{array}{c}\text { nug2/ } \\
\text { EqC }\end{array}$ & \\
\hline & D:Ec & N1c & $\mathrm{N} 2 \mathrm{C}$ & $\mathrm{B}: \mathrm{M}$ \\
\hline Atlantic Energy Inc. . . . . . . . . . . . . . . & 1.35 & 0.342 & 0.034 & 0.66 \\
\hline 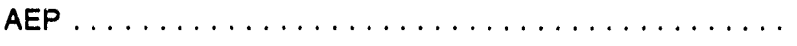 & 1.52 & 0.333 & 0.033 & 0.69 \\
\hline Boston Edison Company $\ldots \ldots \ldots \ldots \ldots \ldots \ldots$ & 2.08 & 0.747 & 0.075 & 0.68 \\
\hline Carolina Power \& Light $\ldots \ldots \ldots \ldots \ldots \ldots \ldots \ldots$ & 1.25 & 0.268 & 0.027 & 0.62 \\
\hline 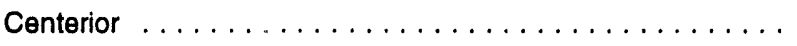 & 1.90 & 0.117 & 0.012 & 1.02 \\
\hline Central Power \& Light $\ldots \ldots \ldots \ldots \ldots \ldots \ldots$ & 1.21 & 0.042 & 0.004 & 0.61 \\
\hline Cincinnati Gas \& Electric Company . . . . . . . . . . . & 1.26 & 0.044 & 0.004 & 0.78 \\
\hline CMS Energy $\ldots \ldots \ldots \ldots \ldots \ldots \ldots \ldots \ldots \ldots$ & 2.14 & 0.942 & 0.283 & 0.49 \\
\hline 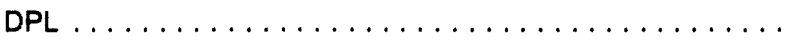 & 1.20 & 0.044 & 0.004 & 0.49 \\
\hline 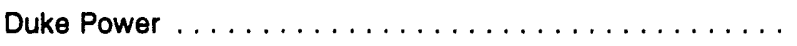 & 1.01 & 0.271 & 0.027 & 0.56 \\
\hline Florida Progress Corporation $\ldots \ldots \ldots \ldots \ldots \ldots \ldots$ & 1.08 & 0.122 & 0.012 & 0.61 \\
\hline FPL Group $\ldots \ldots \ldots \ldots \ldots \ldots \ldots \ldots \ldots \ldots \ldots \ldots \ldots \ldots \ldots \ldots$ & 1.24 & 0.481 & 0.048 & 0.58 \\
\hline General Public Utilities $\ldots \ldots \ldots \ldots \ldots \ldots \ldots$ & 1.25 & 0.679 & 0.085 & 0.78 \\
\hline Houston Lighting \& Power . . . . . . . . . . . . . . & 1.29 & 0.249 & 0.025 & 0.55 \\
\hline Kansas City Power \& Light $\ldots \ldots \ldots \ldots \ldots \ldots$ & 1.17 & 0.043 & 0.004 & 0.61 \\
\hline Now England Electric $\ldots \ldots \ldots \ldots \ldots \ldots \ldots$ & 1.03 & 1.792 & 0.179 & 0.59 \\
\hline Niagara Mohawk Power $\ldots \ldots \ldots \ldots \ldots \ldots \ldots$ & 1.87 & 0.302 & 0.045 & 0.85 \\
\hline 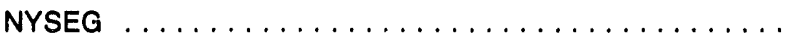 & 1.29 & 0.094 & 0.009 & 0.74 \\
\hline Northern States Power $\ldots \ldots \ldots \ldots \ldots \ldots \ldots$ & 1.05 & 0.155 & 0.015 & 0.60 \\
\hline$\ldots \ldots \ldots \ldots \ldots \ldots \ldots \ldots \ldots \ldots \ldots$ & 1.36 & 0.234 & 0.023 & 0.59 \\
\hline SCE Corporation $\ldots \ldots \ldots \ldots \ldots \ldots \ldots \ldots \ldots \ldots \ldots \ldots \ldots \ldots$ & 1.26 & 0.904 & 0.090 & 0.60 \\
\hline Texas Utilities $\ldots \ldots \ldots \ldots \ldots \ldots \ldots \ldots \ldots \ldots \ldots$ & 1.40 & 0.153 & 0.015 & 0.71 \\
\hline Union Electric Company $\ldots \ldots \ldots \ldots \ldots \ldots$ & 1.00 & 0.076 & 0.008 & 0.57 \\
\hline WI Energy Corporation & 0.83 & 0.136 & 0.014 & 0.56 \\
\hline
\end{tabular}

Sources: Merrill Lynch's U.S. Company and ADR Statistics, The Global Research Review (February 1993), pp. 80-85. Value Line, Investor Survey newsletter. Securities Exchange Commission, Form 10-K, "Annual Report Pursuant to Section 13 or 15(d) of the Securities Exchange Act of $1934^{n}$-individual utility submissions. 
Table C20. Regression Variables: D/E and NUG 1,2,3

\begin{tabular}{|c|c|c|c|c|}
\hline \multirow[b]{2}{*}{ Company } & \multirow[b]{2}{*}{ D:Em } & \multicolumn{3}{|c|}{ X / Common Market Equity Percent Energy } \\
\hline & & NUG1 & NUG2 & NUG3 \\
\hline$\ldots \ldots \ldots \ldots \ldots \ldots \ldots \ldots$ & 0.883 & 0.224 & 0.022 & 0.010 \\
\hline 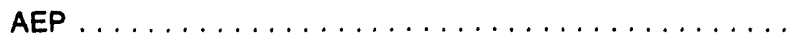 & 1.053 & 0.231 & 0.023 & 0.000 \\
\hline Baltimore Gas \& Electric $\ldots \ldots \ldots \ldots \ldots \ldots \ldots \ldots$ & 0.878 & 0.124 & 0.012 & 0.010 \\
\hline Boston Edison Company $\ldots \ldots \ldots \ldots \ldots \ldots \ldots \ldots$ & 1.415 & 0.508 & 0.051 & 0.100 \\
\hline Carolina Power \& Light $\ldots \ldots \ldots \ldots \ldots \ldots \ldots \ldots$ & 0.777 & 0.167 & 0.017 & 0.065 \\
\hline 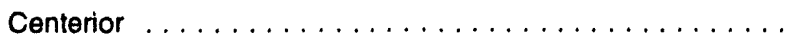 & 1.937 & 0.119 & 0.012 & 0.000 \\
\hline Central Power \& Light . . . . . . . . . . . . . . . . . & 0.737 & 0.025 & 0.003 & 0.026 \\
\hline Cincinnati Gas \& Electric Company $\ldots \ldots \ldots \ldots \ldots \ldots$ & 0.989 & 0.034 & 0.003 & 0.000 \\
\hline CMS Energy $\ldots \ldots \ldots \ldots \ldots \ldots \ldots \ldots \ldots \ldots$ & 1.058 & 0.466 & 0.140 & 0.200 \\
\hline Con Edison $\ldots \ldots \ldots \ldots \ldots \ldots \ldots \ldots \ldots \ldots$ & 0.624 & 0.176 & 0.018 & 0.010 \\
\hline Detroit Edison . . . . . . . . . . . . . . . . . . & 1.087 & 0.043 & 0.004 & 0.010 \\
\hline Dominion Resources, Inc. . . . . . . . . . . . . . . . & 0.808 & 0.185 & 0.037 & 0.078 \\
\hline 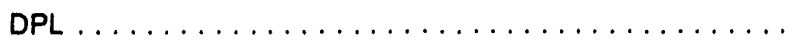 & 0.592 & 0.022 & 0.002 & 0.002 \\
\hline Duke Power $\ldots \ldots \ldots \ldots \ldots \ldots \ldots \ldots \ldots$ & 0.568 & 0.152 & 0.015 & 0.008 \\
\hline Florida Progress Corporation $\ldots \ldots \ldots \ldots \ldots \ldots$ & 0.658 & 0.075 & 0.007 & 0.027 \\
\hline FPL Group $\ldots \ldots \ldots \ldots \ldots \ldots \ldots \ldots \ldots \ldots \ldots \ldots \ldots \ldots \ldots \ldots$ & 0.720 & 0.278 & 0.028 & 0.032 \\
\hline$\ldots \ldots \ldots \ldots \ldots \ldots \ldots \ldots$ & 0.973 & 0.527 & 0.066 & 0.131 \\
\hline Houston Lighting \& Power $\ldots \ldots \ldots \ldots \ldots \ldots \ldots$ & 0.715 & 0.138 & 0.014 & 0.160 \\
\hline Kansas City Power \& Light $\ldots \ldots \ldots \ldots \ldots \ldots$ & 0.709 & 0.026 & 0.003 & 0.000 \\
\hline New England Electric $\ldots \ldots \ldots \ldots \ldots \ldots \ldots$ & 0.611 & 1.065 & 0.106 & 0.150 \\
\hline Niagara Mohawk Power $\ldots \ldots \ldots \ldots \ldots \ldots \ldots$ & 1.597 & 0.258 & 0.039 & 0.110 \\
\hline NYSEG $\ldots \ldots \ldots \ldots \ldots \ldots \ldots \ldots \ldots \ldots \ldots \ldots \ldots \ldots \ldots \ldots \ldots \ldots$ & 0.952 & 0.069 & 0.007 & 0.024 \\
\hline$\ldots \ldots \ldots \ldots \ldots \ldots \ldots \ldots$ & 0.630 & 0.093 & 0.009 & 0.013 \\
\hline Ohio Edison $\ldots \ldots \ldots \ldots \ldots \ldots \ldots \ldots \ldots \ldots \ldots \ldots \ldots \ldots$ & 1.095 & 0.040 & 0.004 & 0.000 \\
\hline Pacific Gas \& Electric $\ldots \ldots \ldots \ldots \ldots \ldots \ldots$ & 0.796 & 0.240 & 0.024 & 0.240 \\
\hline 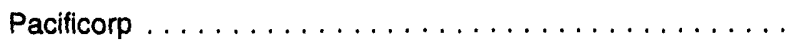 & 1.109 & 0.040 & 0.006 & 0.010 \\
\hline Pennsylvania Power \& Light $\ldots \ldots \ldots \ldots \ldots \ldots$ & 0.866 & 0.030 & 0.003 & 0.098 \\
\hline Portland General Corporation $\ldots \ldots \ldots \ldots \ldots$ & 1.268 & 0.297 & 0.059 & 0.010 \\
\hline Potomac Electric Power Company . . . . . . . . . . . . & 0.768 & 0.085 & 0.009 & 0.001 \\
\hline San Diego Gas \& Electric $\ldots \ldots \ldots \ldots \ldots \ldots \ldots$ & 0.641 & 0.194 & 0.019 & 0.060 \\
\hline 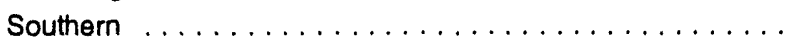 & 0.810 & 0.139 & 0.014 & 0.000 \\
\hline SCE Corporation $\ldots \ldots \ldots \ldots \ldots \ldots \ldots \ldots$ & 0.761 & 0.546 & 0.055 & 0.320 \\
\hline Texas Utilities . . . . . . . . . . . . . . . . . . & 0.990 & 0.108 & 0.011 & 0.120 \\
\hline Union Electric Company $\ldots \ldots \ldots \ldots \ldots \ldots$ & 0.574 & 0.043 & 0.004 & 0.000 \\
\hline WI Energy Corporation $\ldots \ldots \ldots \ldots \ldots \ldots \ldots$ & 0.471 & 0.077 & 0.008 & 0.000 \\
\hline
\end{tabular}

Sources: Merrill Lynch's U.S. Company and ADR Statistics, The Global Research Review (February 1993), pp. 80-85. Value Line, Investor Survey newsietter. Securities Exchange Commission, Form 10-K, "Annual Report Pursuant to Section 13 or 15(d) of the Securities Exchange Act of 1934"-individual utility submissions. 
Appendix D

Selected Provisions

of the Public Utility

Regulatory Policies

Act of 1978 as

Amended 


\section{Appendix D \\ Selected Provisions of the Public Utility Regulatory Policies Act of 1978 as Amended}

P.L 95-617, November 9, 1978, as amended by P.L. 96-2943, June 30, 1980, P.L. 98-620, November 8, 1984, P.L. 99-495, October 16, 1986, P.L. 101-575, November 15, 1990, and P.L. 102-486, October 24, 1992

(19) The term "integrated resource planning" means, in the case of an electric utility, a planning and selection process for new energy resources that evaluates the full range of alternatives, including new generating capacity, power purchases, energy conservation and efficiency, cogeneration and district heating and cooling applications, and renewable energy resources, in order to provide adequate and reliable service to its electric customers at the lowest system cost. The process shall take into account necessary features for system operation, such as diversity, reliability, dispatchability, and other factors of risk; shall take into account the ability to verify energy savings achieved through energy conservation and efficiency and the projected durability of such savings measured over time; and shall treat demand and supply resources on a consistent and integrated basis.

(20) The term "system cost" means all direct and quantifiable net costs for an energy resource over its available life, including the cost of production, distribution, transportation, utilization, waste management, and environmental compliance.

(21) The term "demand side management" includes load management techniques.

\section{TITLE I-RETAIL REGULATORY POLICIES FOR ELECTRIC UTILITIES}

\section{Subtitle A-General Provisions}

Sec. 101. Purposes.

The purposes of this title are to encourage-

(1) conservation of energy supplied by electric utilities;

(2) the optimization of the efficiency of use of facilities and resources by electric utilities; and

(3) equitable rates to electric consumers.

Subtitle B-Standards for Electric Utilities

Sec. 111. Consideration and Determination Respecting Certain Ratemaking Standards.

\footnotetext{
Note: This section was reproduced with the permission of the National Regulatory Research Institute from a report titled "A White Paper on the Energy Policy Act of 1992: An Overview for State Commissions of New PURPA Statutory Standards." The report authored by Robert E. Burns and Mark Eifert was released in April 1993.
} 
(a) CONSIDERATION AND DETERMINATION.-Each State regulatory authority (with respect to each electric utility for which it has rate-making authority) and each nonregulated electric utility shall consider each standard established by subsection (d) and make a determination concerning whether or not it is appropriate to implement such standard to carry out the purposes of this title. For purposes of such consideration and determination in accordance with subsections (b) and (c), and for purposes of any review of such consideration and determination in any court in accordance with section 123, the purposes of this title supplement otherwise applicable State law. Nothing in this subsection prohibits any State regulatory authority or nonregulated electric utility from making any determination that it is not appropriate to implement any such standard, pursuant to its authority under otherwise applicable State law.

(b) Procedural REQUiRementS For CONSIDERATION AND DETERMINATION.-

(1) The consideration referred to in subsection (a) shall be made after public notice and hearing. The determination referred to in subsection (a) shall be-

(A) in writing,

(B) based upon findings included in such determination and upon the evidence presented at the hearing, and

(C) available to the public.

(2) Except as otherwise provided in paragraph (1), in the second sentence of section 112(a), and in sections 121 and 122, the procedures for the consideration and determination referred to in subsection (a) shall be those established by the State regulatory authority or the nonregulated electric utility.

(c) IMPLEMENTATION.--(1) The State regulatory authority (with respect to each electric utility for which it has ratemaking authority) or nonregulated electric utility may, to the extent consistent with otherwise applicable State law-

(A) implement any such standard determined under subsection (a) to be appropriate to carry out the purposes of this title, or

(B) decline to implement any such standard.

(2) If a State regulatory authority (with respect to each electric utility for which it has ratemaking authority) or nonregulated electric utility declines to implement any standard established by subsection (d) which is determined under subsection (a) to be appropriate to carry out the purposes of this title, such authority or nonregulated electric utility shall state in writing the reasons therefor. Such statement of reasons shall be available to the public.

(3) If a State regulatory authority implements a standard established by subsection (d)(7) or (8), such authority shall-

(A) consider the impact that implementation of such standard would have on small businesses engaged in the design, sale, supply, installation or servicing of energy conservation, energy efficiency or other demand side management measures, and

(B) implement such standard so as to assure that utility actions would not provide such utilities with unfair competitive advantages over such small businesses.

(d) ESTABLISHMENT.-The following Federal standards are hereby established:

(7) INTEGRATED RESOURCE PLANNING.-Each electric utility shall employ integrated resource planning. All plans or filings before a State regulatory authority to meet the requirements of this paragraph must be updated on a regular basis, must provide the opportunity for public participation and comment, and contain a requirement that the plan be implemented. 
(8) INVESTMENTS IN CONSERVATION AND DEMAND MANAGEMENT. - The rates allowed to be charged by a State regulated electric utility shall be such that the utility's investment in and expenditures for energy conservation, energy efficiency resources, and other demand side management measures are at least as profitable, giving appropriate consideration to income lost from reduced sales due to investment in and expenditures for conservation and efficiency, as its investments in and expenditures for the construction of new generation, transmission, and distribution equipment. Such energy conservation, energy efficiency resources and other demand side management measures shall be appropriately monitored and evaluated.

(9) ENERGY EFFICIENCY INVESTMENT IN POWER GENERATION AND SUPPLY.-The rates charged by any electric utility shall be such that the utility is encouraged to make investments in, and expenditures for, all cost-effective improvements in the energy efficiency of power generation, transmission and distribution. In considering regulatory changes to achieve the objectives of this paragraph, State $r$-gulatory authorities and nonregulated electric utilities shall consider the disincentives caused by existing ratemaking policies, and practices, and consider incentives that would encourage better maintenance, and investment in more efficient power generation, transmission and distribution equipment.

(10) CONSIDERATION OF THE EFFECTS OF WHOLESALE POWER PURCHASES ON UTILITY COST OF CAPITAL; EFFECTS OF LEVERAGED CAPITAL STRUCTURES ON THE RELIABILITY OF WHOLESALE POWER SELLERS; AND ASSURANCE OF ADEQUATE FUEL SUPPLIES.-(A) To the extent that a State regulatory authority required or allows electric utilities for which it has ratemaking authority to consider the purchase of long-term wholesale power supplies as a means of meeting electric demand, such authority shall perform a general evaluation of:

(i) the potential for increases or decreases in the costs of capital for such utilities, and any resulting increases or decreases in the retail rates paid by electric consumers, that may result from purchases of long-term wholesale power supplies in lieu of the construction of new generation facilities by such utilities;

(ii) whether the use by exempt whulesale generators (as defined in section 32 of the Public Utility Holding Company Act of 1935) of capital structures which employ proportionally greater amounts of debt than the capital structures of such utilities threatens reliability or provides an unfair advantage for exempt wholesale generators over such utilities;

(iii) whether to implement procedures for the advance approval or disapproval of the purchase of a particular long-term wholesale power supply; and

(iv) whether to require as a condition for the approval of the purchase of power that there be reasonable assurances of fuel supply adequacy.

(B) For purposes of implementing the provisions of this paragraph, any reference contained in this section to the date of enactment of the Public Utility Regulatory Policies Act of 1978 shall be deemed to be a reference to the date of enactment of this paragraph.

(C) Notwithstanding any other provision of Federal law, nothing in this paragraph shall prevent a State regulatory authority from taking such action, including action with respect to the allowable capital structure of exempt wholesale generators, as such State regulatory authority may determine to be in the public interest as a result of performing evaluations under the standards of subparagraph $(\mathrm{A})$.

(D) Notwithstanding section 124 and paragraphs (1) and (2) of section 112(a), each State regulatory authority shall consider and make a determination concerning the standards of subparagraph (A) in accordance with the requirements of subsections (a) and (b) of this section, without regard to any proceedings commenced prior to the enactment of this paragraph.

(E) Notwithstanding subsections (b) and (c) of section 112, each State regulatory authority shall consider and make a determination concerning whether it is appropriate to implement the standards set out in subparagraph (A) not later than one year after the date of enactment of this paragraph. 


\section{Sec. 112. Obligations to Consider and Determine.}

(a) REQUEST FOR CONSIDERATION AND DETERMINATION.-Each State regulatory authority (with respect to each electric utility for which it has ratemaking authority) and each nonregulated electric utility may undertake the consideration and make the determination referred to in section 111 with respect to any standard established by section $111(\mathrm{~d})$ in any proceeding respecting the rates of the electric utility. Any participant or intervenor (including an intervenor referred to in section 121) in such a proceeding may request, and shall obtain, such consideration and determination in such proceeding. In undertaking such consideration and making such determination in any such proceeding with respect to the application to any electric utility of any standard established by section 111(d), a State regulatory authority (with respect to any electric utility for which it has ratemaking authority) or nonregulated electric utility may take into account in such proceeding--

(1) any appropriate prior determination with respect to such standard--

(A) which is made in a proceeding which takes place after the date of the enactment of this Act, or

(B) which was made before such date (or is made in a proceeding pending on such date) and complies, as provided in section 124, with the requirement of this title; and

(2) the evidence upon which such prior determination was based (if such evidence is referenced in such proceeding).

(b) TIME Limitations.-(1) Not later than two years after the date of the enactment of this Act (or after the enactment of the Comprehensive National Energy Policy Act in the case of standards under paragraphs (7), (8), and (9) of section 111(d)), each State regulatory authority (with respect to each electric utility for which it has ratemaking authority) and each nonregulated electric utility shall commence the consideration referred to in section 111, or set a hearing date for such consideration, with respect to each standard established by section 111(d).

(2) Not later than three years after the date of the enactment of this Act (or after the enactment of the Comprehensive National Energy Policy Act in the case of standards under paragraphs (7), (8), and (9) of section 111(d)), each State regulatory authority (with respect to each electric utility for which it has ratemaking authority), and each nonregulated electric utility, shall complete the consideration, and shall make the determination, referred to in section 111 with respect to each standard established by section 111(d).

(c) FAILURE TO COMPLY.-Each State regulatory authority (with respect to each electric utility for which it has ratemaking authority) and each nonregulated electric utility shall undertake the consideration, and make the determination, referred to in section 111 with respect to each standard established by section $111(\mathrm{~d})$ in the first rate proceeding commenced after the date three years after the date of enactment of this Act respecting the rates of such utility if such State regulatory authority or nonregulated electric utility has not, before such date, complied with subsection $(b)(2)$ with respect to such standard.

\section{Sec. 117. Relationship to State Law.}

(a) REVENUE AND RATE OF RETURN.-Nothing in this title shall authorize or require the recovery by an electric utility of revenues, or of a rate of return, in excess of, or less than, the amount of revenues or the rate of return determined to be lawful under any other provision of law.

(b) STATE AUTHORITY.-Nothing in this title prohibits any State regulatory or nonregulated electric utility from adopting, pursuant to State law, any standard or rule affecting electric utilities which is different from any standard established by this subtitle.

(c) Federal AGENCIES. - With respect to any electric utility which is a Federal agency, and with respect to the Tennessee Valley Authority when it is treated as a State regulatory authority as provided in section $3(17)$, any reference in section 111 or 113 to State law shall be treated as a reference to Federal law. 


\section{Subtitle C--Intervention and Judicial Review}

\section{Sec. 121. Intervention in Proceedings.}

(a) AUTHORITY TO INTERVENE AND PARTICIPATE.-In order to initiate and participate in the consideration of one or more of the standards established by subtitle B or other concepts which contribute to the achievement of the purposes of this title, the Secretary, any affected electric utility may intervene and participate as a matter of right in any ratemaking proceeding or other appropriate regulatory proceeding relating to rates or rate design which is conducted by a State regulatory authority (with respect o an electric utility for which it has ratemaking authority) or by a nonregulated electric utility.

(b) ACCESS TO INFORMATION.-Any intervenor or participant in a proceeding described in subsection (a) shall have access to information available to other parties to the proceeding if such information is relevant to the issues to which his intervention or participation in such proceeding relates. Such information may be obtained through reasonable rules relating to discovery of information prescribed by the State regulatory authority (in the case of proceedings concerning electric utilities for which it has ratemaking authority) or by the nonregulated electric utility (in the case of a proceeding conducted by a nonregulated electric utility).

(c) EFFECTIVE DATE; PROCEDURES.-Any intervention or participation under this section, in any proceeding commenced before the date of the enactment of this Act but not completed before such date, shall be permitted under this section only to the extent such intervention or participation is timely under otherwise applicable law.

\section{Sec. 122. Consider Representation.}

(a) COMPENSATION FOR COSTS OF PARTICIPATION OR INTERVENTION.-(1) If no alternative means of assuring representation of electric consumers is adopted in accordance with subsection (b) and if an electric consumer of an electric utility substantially contributed to the approval, in whole of in part, of a position advocated by such consumer in a proceeding concerning such utility, and relating to any standard set forth in subtitle B, such utility shall be liable to compensate such consumer (pursuant to paragraph (2)) for reasonable attorney's fees, expert witness fees, and other reasonable costs incurred in preparation and advocacy of such position in such proceeding (including fees and costs of obtaining judicial review of any determination made in such proceeding with respect to such position).

(2) A consumer entitled to fees and costs under paragraph (1) may collect such fees and costs from an electric utility by bringing a civil action in any State court of competent jurisdiction, unless the State regulatory authority (in the case of proceeding concerning a State regulated electric utility) or nonregulated electric utility (in the case of a proceeding concerning such nonregulated electric utility) has adopted a reasonable procedure pursuant to which such authority or nonregulated electric utility-

(A) determines the amount of such fees and costs, and

(B) includes an award of such fees and costs in the proceeding.

(3) The procedure adopted by such State regulatory authority or nonregulated utility under paragraph (2) may include a preliminary proceeding to require that-

(A) as a condition of receiving compensation under such procedure such consumer demonstrate that, but for the ability to receive such award, participation or intervention may be a significant financial hardship for such consumer, and

(B) persons with the same or similar interests have a common legal representative in the proceeding as a condition to receiving compensation. 
(b) Alternative MEANS.-Compensation shall not be required under subsection (a) if the State, the State regulatory authority, or the nonregulated electric utility have provided an alternative means for providing adequate compensation to persons

(1) who have, or represent, an interest-

(A) which would not otherwise be adequately represented in the proceeding, and

(B) representation of which is necessary for a fair determination in the proceeding, and

(2) who are, or represent an interest which is, unable to effectively participate or intervene in the proceeding because such person cannot afford to pay reasonable attorneys' fees, except witness fees, and other reasonable costs of preparing for, and participating or intervening in, such proceeding (including fees and costs of obtaining judicial review of such proceeding).

\section{TITLE III--RETAIL POLICIES FOR NATURAL GAS UTILITIES}

\section{Sec. 301. Purposes; Coverage.}

(a) PURPOSES. - The purposes of this title are to encourage-

(1) conservation of energy supplied by gas utilities;

(2) the optimization of the efficiency of use of facilities and resources by gas utility systems; and

(3) equitable rates to gas consumers of natural gas.

\section{Sec. 302. Definitions.}

For purposes of this title-

(9) The term "integrated resource planning" means, in the case of a gas utility, planning by the use of any standard, regulation, practice, or policy to undertake a systematic comparison between demand-side management measures and the supply of gas by a gas utility to minimize life-cycle costs of adequate and reliable utility services to gas consumers. Integrated resource planning shall take into account necessary features for system operation such as diversity, reliability, dispatchability, and other factors of risk and shall treat demand and supply to gas consumers on a consistent and integrated basis.

(10) The term "demand-side management" includes energy conservation, energy efficiency, and load management techniques.

\section{Sec. 303. Adoption of Certain Standards.}

(a) ADOPTION OF STANDARDS.-Not later than 2 years after the date of the enactment of this Act (or after enactment of the Energy Policy act of 1992 in the case of standards under paragraphs (3) and (4) of subsection (b)), each State regulatory authority (with respect to each gas utility for which it has ratemaking authority) and each nonregulated gas utility shall provide public notice and conduct a hearing respecting the standards established by subsection (b) and, on the basis of such hearing, shall-

(2) adopt the standards established by paragraphs (2), (3) and (4) of subsection (b) if, and to the extent, such authority or nonregulated utility determines that such adoption is appropriate to carry out the purposes of this title, is otherwise appropriate, and is consistent with otherwise applicable State law. 
For purposes of any determination under paragraphs (1) and (2) and any review of such determination in any court under section 307, the purposes of this title supplement State law. Nothing in this subsection prohibits any State regulatory authority or nonregulated utility from making any determination that it is not appropriate to implement any such standard, pursuant to its authority under otherwise applicable State law.

(b) ESTABLISHMENT.-The following Federal standards are hereby established:

(3) INTEGRATED RESOURCE PLANNING.-Each gas utility shall employ, in order to provide adequate and reliable service to its gas customers at the lowest system cost. All plans or filings of a State regulated gas utility before a State regulatory authority to meet the requirements of this paragraph shall (A) be updated on a regular basis, (B) provide the opportunity for public participation and comment, $(C)$ provide for methods of validating predicted performance, and (D) contain a requirement that the plan be implemented after approval of the State regulatory authority. Subsection (c) shall not apply to this paragraph to the extent that it could be construed to require the State regulatory authority to extend the record of a State proceeding in submitting reports to the Federal Government.

(4) INVESTMENTS IN CONSERVATION AND DEMAND MANAGEMENT.-The rates charged by any State regulated gas utility shall be such that the utility's prudent investment in, and expenditures for, energy conservation and load shifting programs and for other demand-side management measures which are consistent with the findings and purposes of the Energy Policy act of 1992 are at least as profitable (taking into account the income lost due to reduced sales resulting from such programs) as prudent investment in, and expenditures for, the acquisition or construction of supplies and facilities. This objective requires that (A) regulators link the utility's net revenues, at least in part, to the utility's performance in implementing cost-effective programs promoted by this section; and (B) regulators ensure that, for purposes of recovering fixed costs, including its authorized return, the utility's performance is not affected by reductions in its retail sales volumes.

(c) PROCEDURAL REQUIREMENTS.-Each State regulatory authority (with respect to each gas utility for which it has ratemaking authority) and each nonregulated gas utility, within the two-year period specified in subsection (a), shall adopt, pursuant to subsection (a), each of the standards established by subsection (b) or, with respect to any such standard which is not adopted, such authority or nonregulated gas utility shall state in writing that it has determined not to adopt such standard, together with the reasons for such determination. Such statement of reasons shall be available to the public.

(d) SMALL BUSINESS IMPACTS.-If a State regulatory authority implements a standard established by subsection (b)(3) or (4), such authority shall-

(1) consider the impact that implementation of such standard would have on small businesses engaged in the design, sale, supply, installation, or servicing of energy conservation, energy efficiency, or other demand-side management measures, and

(2) implement such standard so as to assure that utility actions would not provide such utilities with unfair competitive advantages over such small businesses. 


\section{Glossary .}

\begin{abstract}
Allowance for Funds Used During Construction (AFUDC): A noncash item representing the estimated composite interest costs of debt and a return on equity funds used to finance construction. The allowance is capitalized in the property accounts and included in income.
\end{abstract}

Amortization: The gradual write-off of an amount in an account by distributing such amount over a fixed period, over the life of the asset or liability to which it applies, or over the period during which it is anticipated the benefit will be realized.

Asset: An economic resource, tangible or intangible, which is expected to provide benefits to a business.

Capacity: The amount of electric power delivered or required for which a generator, turbine, transformer, transmission circuit, station, or system is rated by the manufacturer.

Capacity (Purchased): The amount of energy and capacity available for purchase from outside the system.

Capital: The equity interest of the owners consisting of common stock, preferred stock, and retained earnings in the entity, that is the difference between assets and liabilities.

Capital (Financial): The line items on the right side of a balance sheet, that include debt, preferred stock, and common equity. A net increase in assets must be financed by an increase in one or more forms of capital.

Capital Intensive: A condition in which investment in plant and equipment is relatively large compared to labor and to operation and maintenance expenses.

Capitalization: The long-term sources of funds comprising an entity's total capitalization; that is, the long-term debt, preferred stock, and common equity. The short-term sources of capital are not included.

Capitalization Ratio: The percentage of debt, or preferred stock, or common stock, or other equity to the total capital structure of an entity.

Classes of Service: Consumers grouped by similar characteristics in order to be identified for the purpose of setting a common rate for electric service. Usually classified into groups identified as residential, commercial, industrial and other.

Commercial: The commercial sector is generally defined as nonmanufacturing business establishments, including hotels, motels, restaurants, wholesale busi nesses, retail stores, and health, social, and educational institutions. The utility may classify commercial service as all consumers whose demand or annual use exceeds some specified limit. The limit may be set by the utility based on the rate schedule of the utility.

Commercial and Industrial: Classes of service supplied to a similar grouping of consumers. These customer groupings are usually subdivided into smaller segments by classifying such consumers as commercial or industrial using the Federal Government's Office Of Management and Budget's Standard Industrial Classification Guide and/or a scale of energy usage as yardsticks; other consumers are reclassified as commercial or industrial when their demands or annual use exceeds some specified limit. These limits are generally based on a utility's rate schedules, except for those consumers who are supplied under special contracts or agreements calling for particular services.

Common Equity, Book Value: The retained earnings and common stock earnings plus the balances in common equity reserves and all other common stock accounts. This also includes the capital surplus, the paid-in surplus, the premium on common stocks, except those balances specifically related to preferred or preference stocks; less any common stocks held in the treasury.

Common Stock Equity Ratio: The net income after interest taxes and the preferred dividends divided by the average common stock equity.

Construction Costs (of the electric power industry): All direct and indirect costs incurred in acquiring and constructing electric utility plant and equipment and proportionate shares of common utility plant. Included are the cost of land and improvements, nuclear fuel and spare parts, allowance for funds used during construction, general overheads capitalized, less the cost of acquiring plant and equipment previously operated in utility service. 

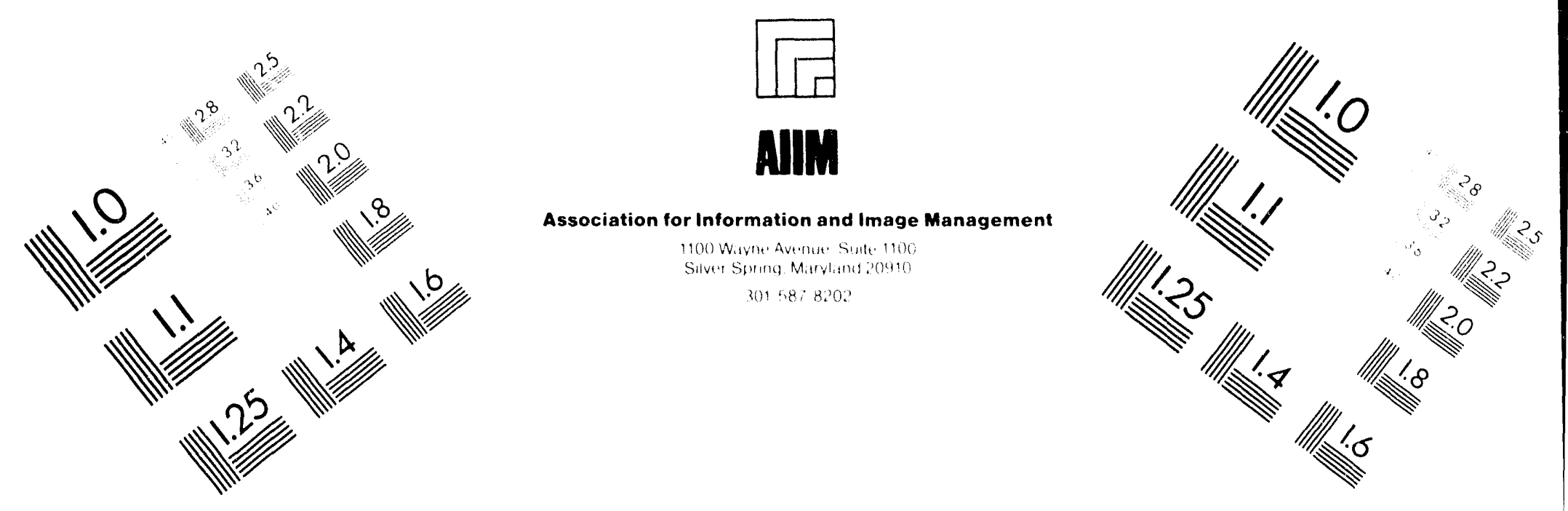

\section{Centimeter}

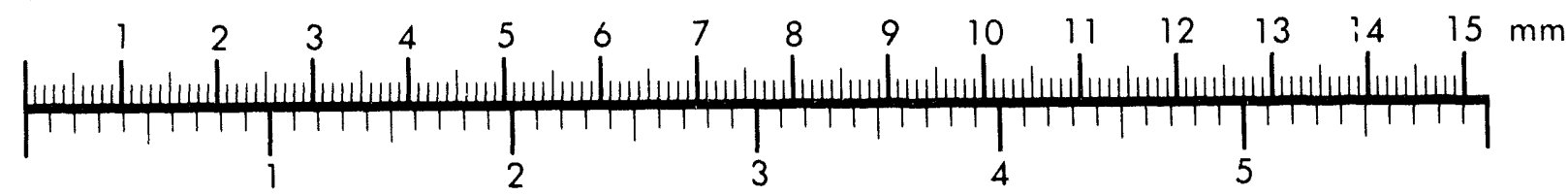
Inches
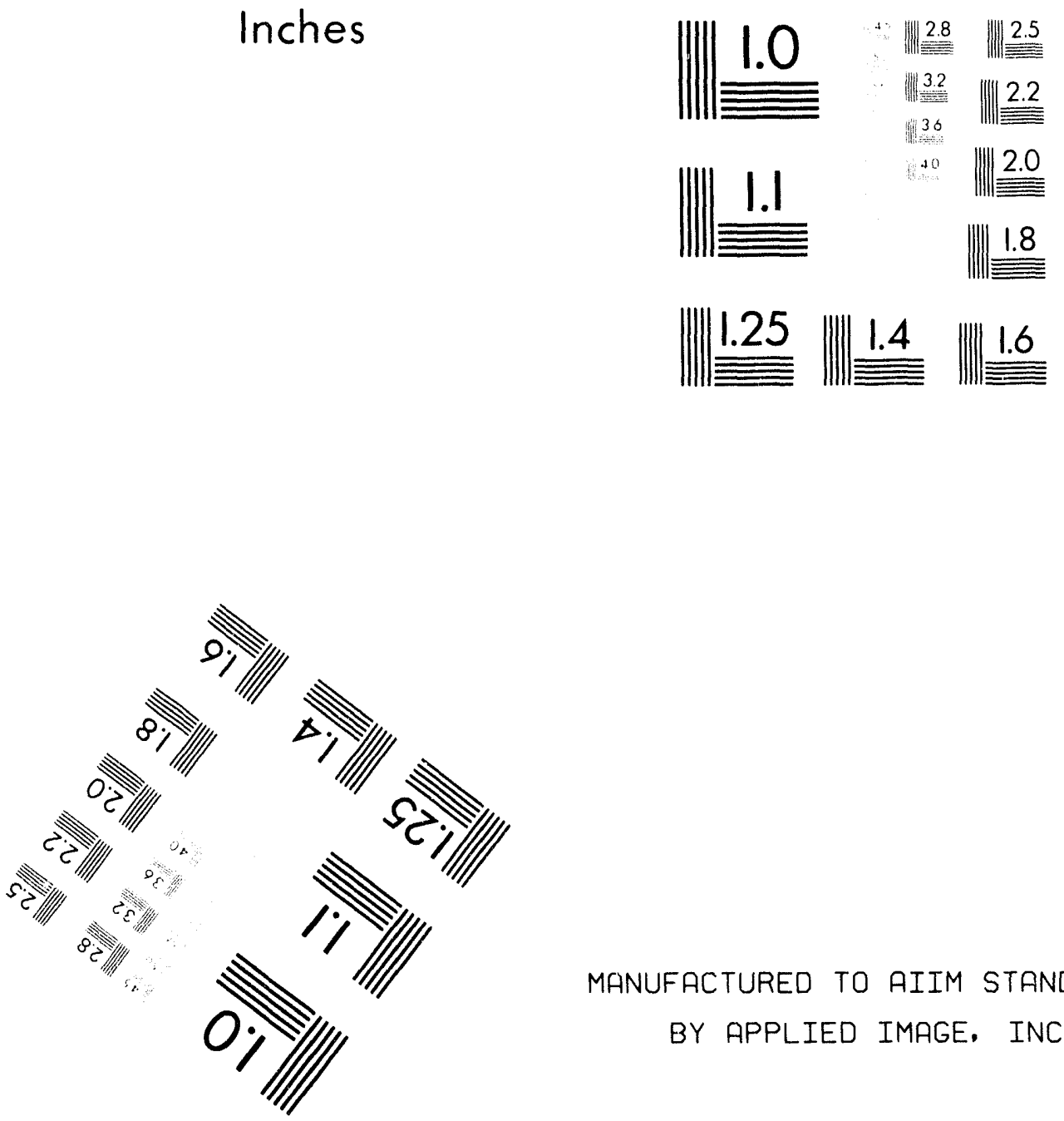

MANUFACTURED TO AIIM STANDARDS BY APPLIED IMAGE. INC.

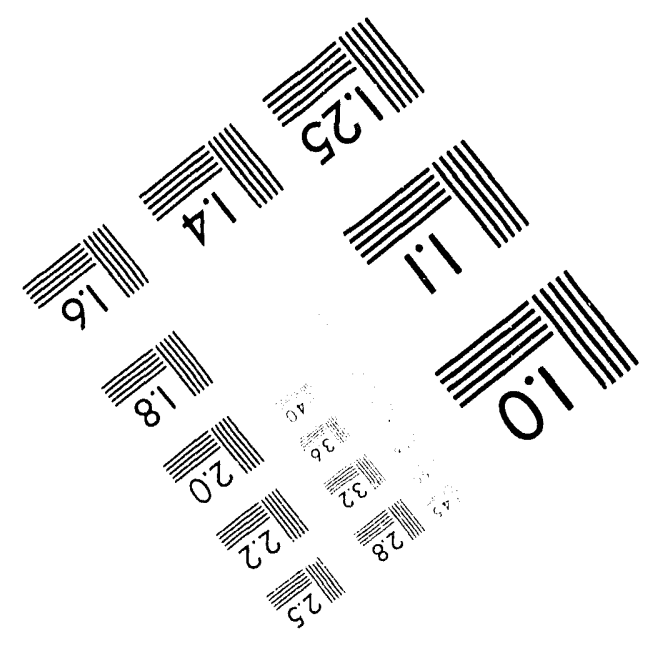



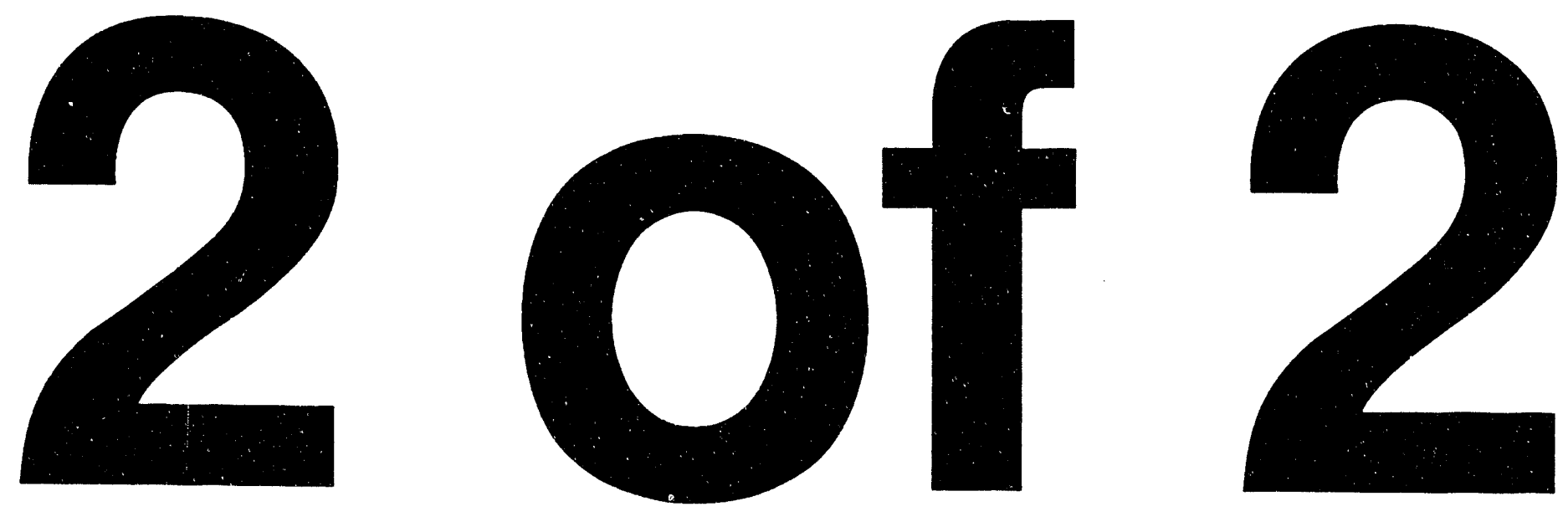
Construction Expenditures (of the electric power industry): The gross expenditures for construction costs, including the cost of replacing worn-out plants, and electric construction costs and land held for future use.

Construction Work In Progress (CWIP): The balance shown on a utility's balance sheet for construction work not yet completed but in process. This balance line item may or may not be included in the rate base.

Cost: The amount paid to acquire resources, such as plant and equipment, fuel, or labor services.

Cost of Capital: The rate of return an entity must offer to obtain additional funds. The cost of capital varies with the leverage ratio, the effective income tax rate, conditions in the bond and stock markets, growth rate of the firm, its dividend strategy, stability of net income, the amount of new capital required, and other factors dealing with business and financial risks. It is a composite of the cost for debt interest, preferred stock dividends, and common stockholders' earnings that provide the facilities used in supplying utility service.

Cost of Debt: The interest rate paid on new increments of debt capital multiplied by 1 minus the tax rate.

Cost of Preferred Stock: Equals the preferred dividend divided by the net price of preferred stock.

Cost of Retained Earnings: The residual of an entity's earnings over expenditures, including taxes and dividends, that are reinvested in its business. The cost of these funds is always lower than the cost of new equity capital, due to taxes and transactions costs. Therefore, the cost of retained earnings is the yield that retained earnings accrue upon reinvestment.

Cost of Service: A ratemaking concept used for the design and development of rate schedules to ensure that the filed rate schedules recover only the cost of providing the electric service at issue. These costs include operating and maintenance expenses, depreciation and amortization expenses, and income and other taxes found just and reasonable by the regulatory agency for ratemaking purposes plus, in the case of privately owned electric utilities, an allowance for a return on capital (usually computed by applying a rate of return to the rate base). This concept attempts to equate the cost incurred by the utility to the revenue received for the service provided to each of the consumer classes.
Current Assets: Cash and other assets that are expected to be turned into cash, sold, or exchanged within the normal operating cycle of the firm, usually or cyear. Current assets include cash, marketable securities, receivables, inventory and current prepayments.

Current Liabilities: A debt or other obligation that must be discharged within a short time, usually the earnings cycle or one year, normally by expending current assets.

Debt: Money or services owed through a legal obligation to an outside party. Debt may be classified short-term which is 1 year or less or long-term which is more than 1 year.

Deferred Fuel Costs: An expenditure for fuel that is not recognized for bookkeeping practices as a cost in the operating period incurred, but carried forward to be written off in future periods.

Deferred Income Tax: Usually, a liability in the balance sheet representing the additional Federal income taxes that would have been due if a company had not been allowed to compute tax expenses differently for income tax reporting purposes than for ratemaking reporting purposes.

Depreciation: Charges made against income for distributing the cost of a tangible asset, so as to allocate it systematically across the period in which the asset is used.

Docket: A formal record of a Federal Energy Regulatory Commission proceeding. These records are available for inspection and copying by the public. Each individual case proceeding is identified by an assigned number.

Earnings Quality (electric power industry): The relative ratio of cash earnings to reported earnings. The relative ratio is the sum of internal cash generation, plus dividends on common stock, dividends on cooperative memberships, or funds remitted to the general fund for public entities-- excluding, however, such noncash credits as the allowance for funds used during construction (interest capitalized)--to the reported earnings on common stock (for investor owned companies), earnings on memberships (for cooperatives), or funds reserved for plant expansion, plus those remitted to the general fund (for public entities). 
Electric Operating Expenses: Summation of electric operation-related expenses, such as operation expenses, maintenance expenses, depreciation expenses, amortization, taxes other than income taxes, Federal income taxes, other income taxes, provision for deferred income taxes, provision for deferred income-credit, and investment tax credit adjustment.

Electric Power Industry: The privately, publicly, federally and cooperatively owned electric utilities of the United States taken as a whole. This includes all electric systems serving the public\&colon. regulated investor-owned electric utility companies; Federal power projects; State, municipal, and other government-owned systems, including electric public utility districts; electric cooperatives, including generation and transmission entities. Excluded from this definition are the special purpose electric facilities or systems that do not offer service to the public.

Electric Utility: A corporation, person, agency, authority, or other legal entity or instrumentality that owns and/or operates facilities within the United States, its territories, or Puerto Rico for the generation, transmission, distribution, or sale of electric energy primarily for use by the public and files forms listed in the Code of Federal Regulations, Title 18, Part 141. Facilities that qualify as cogenerators or small power producers under the Public Utility Regulatory Policies Act (PURPA) are not considered electric utilities.

Energy: The capacity for doing work as measured by the capability of doing work (potential energy) or the conversion of this capability to motion (kinetic energy). Energy has several forms, some of which are easily convertible and can be changed to another form useful for work. Most of the world's convertible energy comes from fossil fuels that are burned to produce heat that is then used as a transfer medium to mechanical or other means in order to accomplish tasks. Electrical energy is usually measured in kilowatthours, while heat energy is usually measured in British thermal units.

Energy Information Administration (EIA): An independent agency within the U.S. Department of Energy that develops surveys, collects energy data, and does analytical and modeling analyses of energy issues. The Agency must satisfy the requests of Congress, other elements within the Department of Energy, Federal Energy Regulatory Commission, the Executive Branch, its own independent needs, and assist the general public, or other interest groups, without taking a policy position.

EPACT: The Energy Policy Act of 1992
Equity (Financial): Ownership interest of shareholders in a corporation represented by stock.

Equity Capital: The sum of capital from retained earnings and the issuance of stocks.

Expenditure: The incurrence of a liability to obtain an asset or service.

Federal Energy Regulatory Commission (FERC): A quasi-independent regulatory agency within the Department of Energy having jurisdiction over interstate electricity sales, wholesale electric rates, hydroelectric licensing, natural gas pricing, oil pipeline rates, and gas pipeline certification.

Federal Power Act: Enacted in 1920, and amended in 1935, the Act consists of three parts. The first part incorporated the Federal Water Power Act administered by the former Federal Power Commission, whose activities were confined almost entirely to licensing non-Federal hydroelectric projects. Parts II and III were added with the passage of the Public Utility Act. These parts extended the Act's jurisdiction to include regulating the interstate transmission of electrical energy and rates for its sale as wholesale in interstate commerce. The Federal Energy Regulatory Commission is now charged with the administration of this law.

Federal Power Commission: The predecessor agency of the Federal Energy Regulatory Commission. The Federal Power Commission (FPC) was created by an Act of Congress under the Federal Water Power Act on June 10,1920 . It was charged originally with regulating the electric power and natural gas industries. The FPC was abolished on September 20,1977, when the Department of Energy was created. The functions of the FPC were divided between the Department of Energy and the Federal Energy Regulatory Commission.

FERC: The Federal Energy Regulatory Commission.

Fixed Cost (expense): An expenditure or expense that does not vary with volume of activity.

Generating Unit: Any combination of physically connected generator(s), reactor(s), boiler(s), combustion turbine(s), or other prime mover(s) operated together to produce electric power.

Generator Nameplate Capacity: The full-load continuous rating of a generator, prime mover, or other electric power production equipment under specific conditions as designated by the manufacturer. Installed 
generator nameplate rating is usually indicated on a nameplate physically attached to the generator.

Gross Generation: The total amount of electric energy produced by a generating facility, as measured at the generator terminals.

Holding Company: A company that confines its activities to owning stock in, and supervising managernent of, other companies. The Securities and Exchange Commission, as administrator of the Public Utility Holding Company Act of 1935, defines a holding company as a company which directly or indirectly owns, controls or holds 10 percent or more of the outstanding voting securities of a holding company:eq. (15 USC 79b, par. a (7)).

Independent Power Producer: A corporation, person, agency, authority, or other legal entity or instrumentality that owns electric generating capacity and is a wholesale electric producer without a designated franchised service area. The entity is not a qualifying facility as defined in the Public Utility Regulatory Policies Act of 1978.

Industrial: The industrial sector is generally defined as manufacturing, construction, mining, agriculture, fishing and forestry establishments Standard Industrial Classification (SIC) codes 01-39. The utility may classify industrial service using the SIC codes, or based on demand or annual usage exceeding some specified limit. The limit may be set by the utility based on the rate schedule of the utility.

Interest Coverage Ratio: The number of times that fixed interest charges were earned indicates the margin of safety of interest on fixed debt. The timesinterest-earned ratio is calculated using net income before and after income taxes; and the credits of interest charged to construction being treated as other incomes. The interest charges include interest on long-term debt, interest on debt of associated companies, and other interest expense.

Internal Cash Flow: Composed of funds available for common stockholders after adjustments for common stock equivalents, depreciation and depletion, amortization, deferred income taxes (net), investment tax credit (net), and other internal sources (net); less common dividends and AFUDC (total).

Investor-Owned Electric Utility: A class of utility that is investor owned and organized as a tax paying business, usually financed by the sales of securities in the capital market.
Kilowatt (Kw): One thousand watts.

Kilowatthour (Kwh): One thousand watthours.

Leverage Ratio: A measure that indicates the financial ability to meet debt service requirements and increase the value of the investment to the stockholders. (i.e. the ratio of total debt to total assets).

Liability: An amount payable in dollars or by future services to be rendered.

Load (Electric): The amount of electric power delivered or required at any specific point or points on a system. The requirement originates at the energy-consuming equipment of the consumers.

Long-term Debt: Debt securities or borrowings having a maturity of more than a year.

Maintenance Expenses: That portion of operating expenses consisting of labor, materials, and other direct and indirect expenses incurred for preserving the operating efficiency and/or physical condition of utility plants used for power production, transmission, and distribution of energy.

Megawatt (MW): One million watts.

Megawatthour (MWh): One million watthours.

Net Generation: Gross generation minus plant use from all electric utility owned plants. The energy required for pumping at a pumped-storage plant is regarded as plant use and must be deducted from the gross generation.

Net Income: The excess of all revenues and gains for a period over all expenses and losses of the period.

Nonutility Power Producer: A corporation, person, agency, authority, or other legal entity or instrumentality that owns electric generating capacity and is not an electric utility. Nonutility power producers include qualifying cogenerators, qualifying small power producers, and other nonutility generators (including independent power producers) without a designated franchised service area, and which do not file forms listed in the Code of Federal Regulations, Title 18, Part 141.

Operating Expenses: Expenses related to utility operations, which include operation and maintenance expenses, provisions for depreciation and amortization, taxes other than income taxes, income taxes, provision 
for deferred income taxes, income taxes deferred in prior years-credit and investment tax credit adjustments-net.

Operating Income: Operating revenues less operating expenses.

Operation Expenses: The components of power production expenses that incur cost for operations that are directly related to producing electricity. The major item is almost always fuel that has to be burned to generate the electricity.

Owners Equity: Interest of the owners in the assets of the business represented by capital contributions and retained earnings.

Parent Company: Company owning more than 50 percent of the voting shares of another company, called the subsidiary.

Plant: A facility at which are located prime movers, electric generators, and auxiliary equipment for converting mechanical, chemical, and/or nuclear energy into electric energy. A plant may contain more than one type of prime mover. Electric utility plants exclude facilities that satisfy the definition of a qualifying facility under the Public Utility Regulatory Policies Act of 1978 .

Power: The rate at which energy is transferred. Electrical energy is usually measured in watts. Also used for a measurement of capacity.

Power Production Plant: All the land and land rights, structures and improvements, boiler or reactor vessel equipment, engines and engine-driven generator, turbogenerator units, accessory electric equipment, and miscellaneous power plant equipment are grouped together for each individual facility.

Preferred Stock: Ownership interests in a corporation which have been granted a preference, usually in the distribution of dividends before payment of dividends to common stockholders and assets in dissolution. It is usually nonvoting.

Price: The amount of money or consideration-in-kind for which a service is bought, sold, or offered for sale.

Production (Electric): Act or process of producing electric energy from other forms of energy; also, the amount of electric energy expressed in watthours (Wh).
Production Expenses: Costs incurred in the production of electric power that conform to the accounting requirements of the Operation and Maintenance Expense Accounts of the FERC Uniform System of Accounts.

Profit: The income remaining after all business expenses are paid.

PUHCA: The Public Utility Holding Company Act of 1935

PURPA: The Public Utility Regulatory Policies Act of 1978

Purchased Power: Power purchased or available for purchase from a source outside the system.

Rate Base: The value of property upon which a utility is permitted to earn a specified rate of return as established by a regulatory authority. The rate base generally represents the value of property used by the utility in providing service and may be calculated by any one or a combination of the following accounting methods: fair value, prudent investment, reproduction cost, or original cost. Depending on which method is used, the rate base includes cash, working capital, materials and supplies, and deductions for accumulated provisions for depreciation, contributions in aid of construction, customer advances for construction, accumulated deferred income taxes, and accumulated deferred investment tax credits.

Ratemaking Authority: A utility commission's legal authority to fix, modify, approve, or disapprove rates, as determined by the powers given the commission by a State or Federal legislature.

Rate of Return: The ratio of net operating income earned by a utility is calculated as a percentage of its rate base.

Rate of Return on Common Equity: Net income less preferred stock dividends divided by common stock equity.

Regulation: The governmental function of controlling or directing economic entities through the process of rulemaking and adjudication.

Residential: The residential sector is defined as private household establishments which consume energy primarily for space heating, water heating, air conditioning, lighting, refrigeration, cooking and clothes drying. The classification of an individual consumer's 
account, where the use is both residential and commercial, is based on principal use. For the residential class, do not duplicate consumer accounts due to multiple metering for special services (water, heating, etc.). Apartment houses are also included.

Retail: Sales covering electrical energy supplied for residential, commercial, and industrial end-use purposes. Other small classes, such as agriculture and street lighting, also are included in this category.

Retained Earnings: The balance, either debit or credit, of appropriated or unappropriated earnings of an entity that are retained in the business.

Return on Common Equity: An entity's earnings available for common stockholders calculated as a percentage of its common equity capital.

Revenue: The total amount of money received by a firm from sales of its products and/or services, gains from the sales or exchange of assets, interest and dividends earned on investments, and other increases in the owner's equity except those arising from capital adjustments.

Revenue Requirement: The total revenue that the utility is authorized an opportunity to recover, which includes operating expenses and a reasonable return on rate base.

Sales: The amount of kilowatthours sold in a given period of time; usually grouped by classes of service, such as residential, commercial, industrial, and other. Other sales include public street and highway lighting, other sales to public authorities and railways, and interdepartmental sales.

Sales for Resale: Energy supplied to other electric utilities, cooperatives, municipalities, and Federal and State electric agencies for resale to ultimate consumers.

Short-term Debt or Borrowings: Debt securities or borrowings having a maturity of less than 1 year.

Ultimate Consumer: A consumer that purchases electricity for its own use and not for resale.

Uniform System of Accounts: Prescribed financial rules and regulations established by the Federal Energy Regulatory Commission for utilities subject to its jurisdiction under the authority granted by the Federal Power Act.

Utility Generation: Generation by electric systems engaged in selling electric energy to the public. 


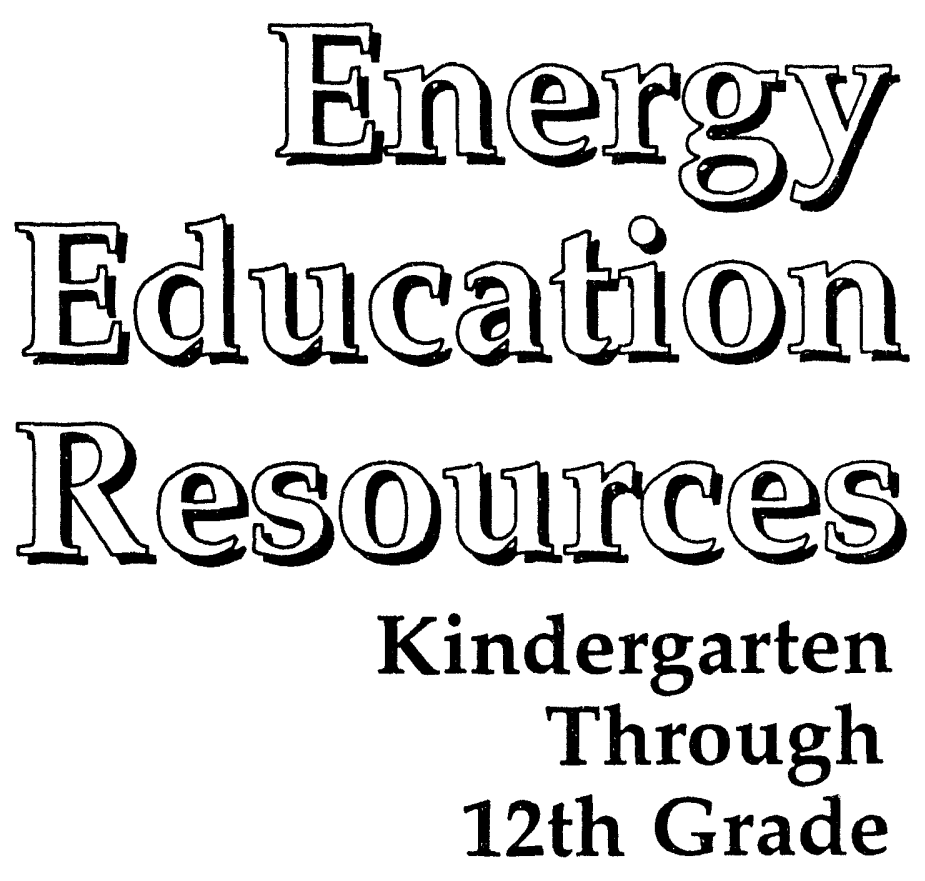

This brochure contains a listing of free or low-cost energy-related educational materials for educators and primary and secondary students.

\section{Call the National Energy Information Center on (202)586-8800 to order your free copy.}



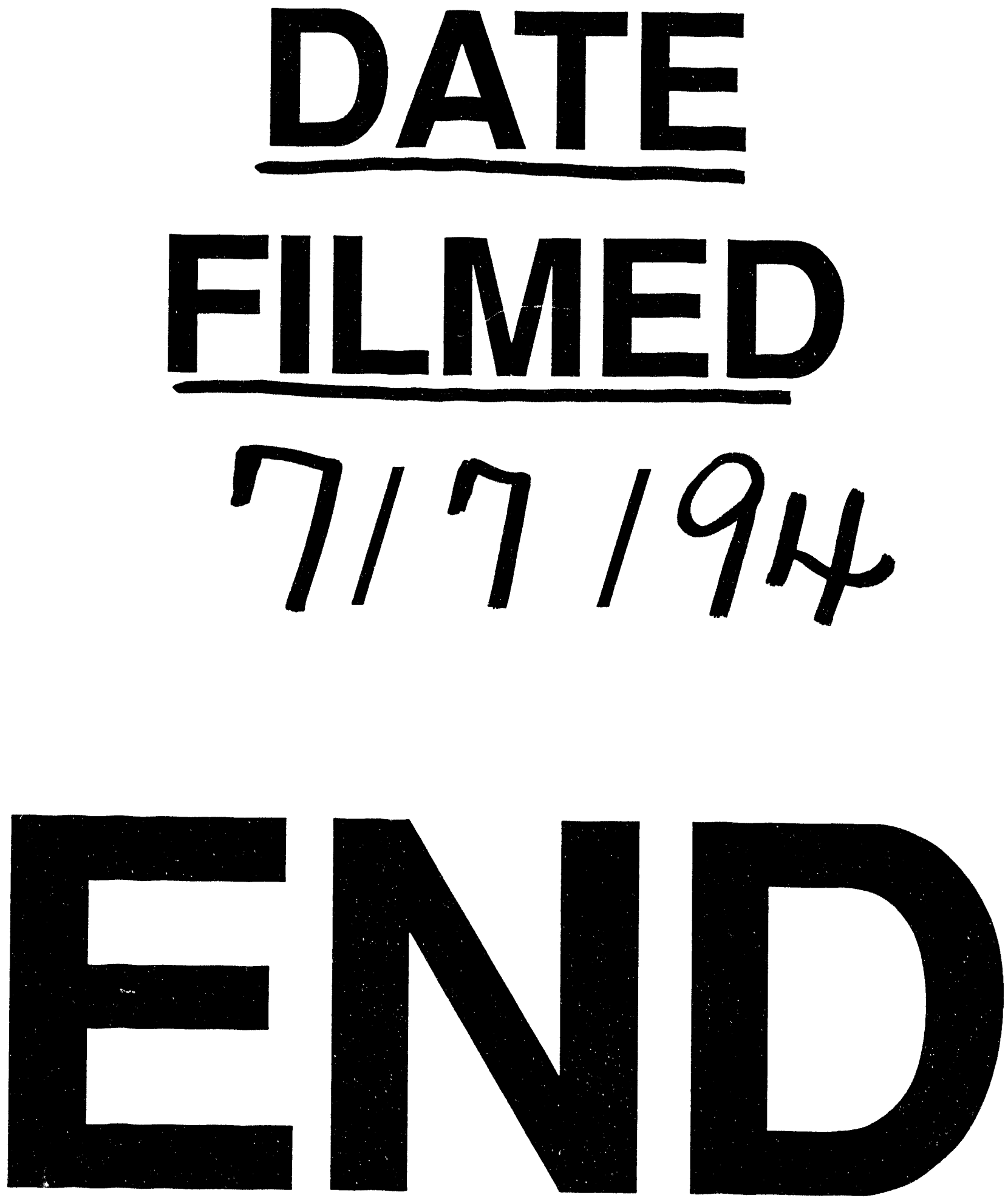
